\title{
Desenvolvimento e mudança social formação da sociedade urbano-industrial no Brasil
}

\author{
Juarez Rubens Brandão Lopes
}

\section{SciELO Books / SciELO Livros / SciELO Libros}

LOPES, JRB. Desenvolvimento e mudança social: formação da sociedade urbano-industrial no Brasil [online]. Rio de Janeiro: Centro Edelstein de Pesquisas Sociais, 2008. 233 p. ISBN: 978-85-99662-823. Available from SciELO Books $<\underline{\text { http://books.scielo.org }>\text {. }}$

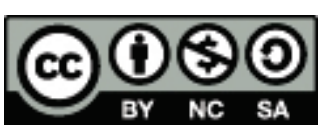

All the contents of this chapter, except where otherwise noted, is licensed under a Creative Commons Attribution-Non Commercial-ShareAlike 3.0 Unported.

Todo o conteúdo deste capítulo, exceto quando houver ressalva, é publicado sob a licença Creative Commons Atribuição Uso Não Comercial - Partilha nos Mesmos Termos 3.0 Não adaptada.

Todo el contenido de este capítulo, excepto donde se indique lo contrario, está bajo licencia de la licencia Creative Commons Reconocimento-NoComercial-CompartirIgual 3.0 Unported. 


\section{Juarez Rubens Brandão Lopes}

\section{Desenvolvimento e mudança social formação da sociedade urbano-industrial no Brasil}

Esta publicação é parte da Biblioteca Virtual de Ciências Humanas do Centro Edelstein de Pesquisas Sociais - www.bvce.org

Copyright (C) 2008, Juarez Rubens Brandão Lopes

Copyright (C) 2008 desta edição on-line: Centro Edelstein de Pesquisas Sociais

Nenhuma parte desta publicação pode ser reproduzida ou transmitida por qualquer meio de comunicação para uso comercial sem a permissão escrita dos proprietários dos direitos autorais. A publicação ou partes dela podem ser reproduzidas para propósito não-comercial na medida em que a origem da publicação, assim como seus autores, seja reconhecida.

ISBN 978-85-99662-82-3

Centro Edelstein de Pesquisas Sociais

www.centroedelstein.org.br

Rua Visconde de Pirajá, 330/1205

Ipanema - Rio de Janeiro - RJ

www.centroedelstein.org.b

CEP: 22410-000. Brasil

Rio de Janeiro

Contato: bvce@centroedelstein.org.br 
Introdução

\section{Primeira Parte}

Desenvolvimento econômico e urbanização no Brasil

I - Aspectos do desenvolvimento econômico.

1. Urbanização e formação de "mercados internos" 12

2. Desenvolvimento, concentração industrial e mercado nacional 18

\section{II - O processo de urbanização}

1. Contornos gerais do processo

2. A urbanização nas regiões adiantadas e nas atrasadas

III - As conseqüências da concentração do desenvolvimento no

\section{Centro-sul}

1. A agricultura

2. $\mathrm{O}$ artesanato

$\begin{array}{ll}\text { 3. As migrações inter-regionais } & 59 \\ \text { 4. O processo de modernização } & 78\end{array}$

IV - As áreas urbanizadas e não-urbanizadas do país

Segunda Parte Erro! Indicador não definido.

Transformações políticas e sociais no Brasil

V - A transformação política

VI - A sociedade urbano-industrial em formação

$\begin{array}{lc}\text { 1. A burocratização } & 106 \\ \text { 2. Secularização e individualização } & 126 \\ \text { Apêndice: Controle da natalidade } & 154 \\ \text { 3. Industriais, novas classes e médias e operariado } & 159 \\ \text { 4. Contatos, comunicações e valores } & 182\end{array}$

VII - Desagregação da sociedade patrimonialista 206

Conclusão

Bibliografia
Almejamos com este estudo do desenvolvimento e mudança social no Brasil ${ }^{1}$ contribuir para o entendimento da transformação em curso na nossa sociedade e economia, estudando-a sob o ângulo dos processos de industrialização e urbanização. Analisa-se aqui, portanto, a constituição de uma sociedade urbano-industrial entre nós, o que vale dizer, tenta-se compreender como se industrializou e urbanizou o Brasil, quais os aspectos mais salientes desses processos e, sobretudo, quais as suas consequiências sociais.

Desde já deve ser dito, o nosso principal interesse reside na caracterização e interpretação das mudanças econômicas e sociais da sociedade brasileira, como processo global. Esse objetivo será abordado sob a perspectiva do desenvolvimento de um sistema industrial e de uma sociedade urbano-industrial no Brasil. Tal sistema e sociedade implicam integração econômica, política e social. Significam mercado nacional, meios modernos de comunicações e estrutura político-administrativa abrangentes, no seu escopo e na sua atuação, de todas as regiões do país e setores do corpo nacional, intenso intercâmbio social entre as mesmas regiões e setores, educação e cultura de massa, identificação nacional ${ }^{2}$, etc.

\section{Esclareçamos melhor essas idéias.}

Escreve Olson sobre a sociedade da massa contemporânea:

\footnotetext{
${ }^{1}$ Nessa monografia, desenvolvimento é entendido como envolvendo, em essência, mudança estrutural da sociedade e da economia. (Sobre uso do conceito com esse sentido, ver, entre outros, SEERS, 1963 e DEMAS, 1965.) Assim, "desenvolvimento econômico" é uma forma de "mudança social". Não se procura, portanto, neste trabalho, relacionar esses fenômenos concebidos como distintos. O título do livro indica apenas o esforço de se chegar a uma compreensão interdisciplinar do processo de transformação da sociedade brasileira. Ver, também, sobre isso, a nota 1 do capítulo I. ${ }^{2}$ Sobre a identificação nacional, dizem SILVERT e BONILLA: "[It is an] identification, with all the fellow-citizens involved in explicitly recognized common activities; and acceptance of the state as the highest institutionalized secular authority". SILVERT e BOXILLI, 1961, p.16. Ver também cap. VI, p.195.
} 
[Ela é] caracterizada por um núcleo de instituições centrais que integram todas as atividades da população total e dão direção e estrutura às suas atividades quotidianas. Nas posições-chaves dessas instituições estão pessoas com influência sobre a atividade institucional; a essas pessoas C. Wright Mills denominou de "elite do poder". O fator integrador dessa sociedade é uma ordem tecnológica e industrial que facilita as comunicações por todas as suas "regiões" e possibilita uma estrutura ocupacional altamente especializada e diversificada. Ao mesmo tempo, a existência dessa ordem coloca a base para uma cultura comum a toda a sociedade (chamada às vezes de "cultura de massa", às vezes de "cultura popular") pelo desenvolvimento de uma rede de disseminação cultural, comum ente denominada "comunicações de massa". Urbanização e burocracia são características dessa ordem industrial e técnica, pois servem como focos donde emanam as forças institucionais e fornecem um sistema organizacional para estruturar a ação. No centro urbano localizam-se as atividades da elite, a criatividade cultural e a organização burocrática (...) é o centro da sociedade de massa ${ }^{3}$

Com as expressões "sistema industrial" e "sociedade urbanoindustrial" desejamos nos referir a essa estrutura sócio-econômica global, caracterizada por Olson como sociedade de massa, porém com ênfases distintas, no caso de uma e outra expressão. Com a primeira a atenção é concentrada nos aspectos tecnológicos, econômicos e demo gráficos daquela estrutura (industrialismo, meios modernos de comunicação, mercado nacional, urbanização), com a segunda, a de "sociedade urbanoindustrial", nos seus aspectos institucionais, culturais, psicológicos e sociais (burocratização, cultura de massa, estratificação social e orientações da conduta características, etc. $)^{4}$.

Tais fenômenos entre nós, é importante lembrar, prendem-se - para usar formulações de Florestan Fernandes ${ }^{5}$ - à "formação e (...) integração da

\footnotetext{
${ }^{3}$ OLSON, 1963, p.4-5.
}

${ }^{4}$ Sobre o uso de "sistema industrial", "industrialismo" e "sociedade urbano-industrial", com sentidos similares aos aqui empregados, ver, entre outros, COLE, 1954; FRIEDMANN, 1946; e KERR e outros, 1960.

${ }^{5}$ FERNANDES, 1963, p.202, e FERNANDES, 1965, p.19, e outros de seus trabalhos. sociedade de classes no sistema capitalista de produção econômica" e ao desenvolvimento da "correspondente ordem social competitiva". Toca-se aqui em problema teórico intrincado que não cabe tratar nos limites que traçamos para esta monografia. Apenas o mencionamos; tratar-se-ia de determinar em que medida a mudança social vincula-se à implantação aqui do industrialismo em si e, em que medida, antes de tudo, as formas concretas daquela mudança social se ligam a sistemas sociais globais, como o indicado pelo conceito de capitalismo ou, ainda mais, ao modo específico como nele se insere, na periferia daquele sistema, a sociedade de classes em desenvolvimento no Brasil ${ }^{6}$. Sem tratar de problemas como esse, procuramos por ora contribuir apenas para a caracterização das formas concretas pelas quais se está dando a mudança social no Brasil, nas suas vinculações com a industrialização e a urbanização.

Muitos são os esforços que já foram feitos para explicar o desenvolvimento do Brasil dos pontos de vista econômico, sociológico e político $^{7}$ Lançar-se-á mão de alguns desses estudos, na medida em que a interpretação da sociedade brasileira em mudança requerer uma formulação de como aqui se deu o desenvolvimento. Por outro lado são muitos os estudos e pesquisas de mudanças sociais no Brasil. Tratam dos mais variados aspectos sobre a organização econômica, as instituições sociais e políticas, as ideologias e valores; foram feitas por geógrafos, economistas, sociólogos e cientistas políticos; uns têm o cunho monográfico, de estudos de comunidade ${ }^{8}$, outros de amplos levantamentos; utilizam-se de variadas

${ }^{6}$ Ver, como ilustrativos, os pontos de vista de FRIEDMANN, 1950. Especialmente no apêndice "Milieu technique et structure sociale", págs. 369-76; CARDOSO, 1964 (b) e PEREIRA. - 1965, cap. III, em especial págs. 79-83. Deste último, destaque-se; por exemplo. A seguinte frase: "Como a história dos demais subsistemas periféricos, enquanto periférico, também o Brasil determina-se fundamentalmente como sucessão de articulações ou rearticulações de nossa sociedade a subsistemas dominantes capitalistas" (p.79).

Ver, entre outros, FURTADO, 1959; PRADO JR., 1956; RANGEL, 1956; FERNANDES, 1960; CARDOSO, 1964 (a), e JAGUARIBE, 1962.

${ }^{8}$ Há limitaçẽes sérias ao uso dos resultados da vintena de estudos de comunidade realizados no Brasil nos últimos vinte anos; primeiro devido a problemas de comparabilidade; em segundo lugar porque quase nunca analisam, no dizer de IANNI, "as conexões da comunidade com o sistema econômico-social inclusivo, capitalista, em expansão" (IANNI, 1961, p.113). Usamos os seus 
posições metodológicas e teóricas. Este trabalho visou utilizar todas essas diversas contribuições para ver até que ponto ajudam na tentativa de interpretação da mudança social no Brasil, sob a perspectiva adotada. No mesmo sentido, utilizaram-se pesquisas do autor ${ }^{9}$ e dados dos censos e das mais diversas estatísticas econômicas, sociais e culturais ${ }^{10}$.

Em suma, procurou-se reunir os mais variados estudos, pesquisas e índices estatísticos, relacionando-os no que têm de pertinente com um modo sistemático de interpretação da mudança social no Brasil, qual seja o desenvolvimento entre nós de um sistema industrial e de uma sociedade urbano-industrial.

Muito do que será formulado, diga-se desde já, parece sê-lo de modo conclusivo, mas isso ocorre apenas por conveniência de exposição, tendo as afirmações, ao contrário, o caráter de colocações exploratórias e preliminares. Não podia mesmo deixar de ser assim em trabalho de interpretação, com base em pesquisas raras, cujos resultados o mais das vezes não são bem comparáveis. Pretendemos, sobretudo, esboçar um quadro das mudanças sociais em curso, que sirva a investigações futuras.

Por ora nos será útil relacionar o nosso tema a um contexto mais amplo. A aceleração do ritmo de urbanização do Brasil, a partir do século passado, tem por causa básica a industrialização. Este é um fato universal. É: a revolução industrial, principalmente desde a segunda metade do século XVIII, que vem criando o mundo moderno urbano e, no mesmo passo, constituindo uma sociedade urbano-industrial. Examinemos com mais vagar essas duas assertivas.

resultados, na medida do possível, conscientes desses percalços e procurando justamente inseri-los no quadro das mudanças da sociedade global.

${ }^{9}$ Ver LOPES, 1964 e 1967.

${ }^{10}$ Dois exemplos recentes de levantamentos de grande interesse sociológico são o censo escolar de 1964, realizado pelo Ministério da Educação e Cultura e pelo IBGE, em todo o território nacional, e a pesquisa sobre orçamentos familiares, realizada em 1961-63, em capitais e cidades do interior de vários tamanhos, pelo Instituto Brasileiro de Economia da Fundação Getúlio Vargas. Ambos começam agora a ser publicados. Ver Censo escolar do Brasil, 1965, e Pesquisa sobre orçamentos familiares $(a)$ e $(b)$, s/d.
Kingsley Davis, em amplo exame do processo de urbanização na história da humanidade, fornece o seguinte panorama". A "revolução urbana", assim denominada pelos arqueólogos; tem lugar pela primeira vez ao redor de 4.000 ou 3.000 a.C. na Mesopotâmia e no Egito. Surgem então as primeiras verdadeiras cidades, na base da produção de um excedente agrícola. Uma segunda onda de urbanização ocorre durante o Império Romano. Aparecem cidades de tamanho sem precedentes. Roma alcança algumas centenas de milhares de habitantes. As mais favoráveis estimativas da urbanização do Mundo Antigo, entretanto, não colocam mais de um a dois por cento da população como habitantes de aglomerados urbanos. $\mathrm{O}$ início do processo moderno de urbanização do mundo ocidental data do renascimento do comércio nos séculos XI e XII. Não se ultrapassou, porém, a porcentagem de população urbana do Mundo Antigo muito antes do século XIX. São as seguintes as porcentagens que apresenta Davis para a população de núcleos de vinte mil ou mais, e de cem mil ou mais habitantes, em relação à população mundial:

Quadro I

Porcentagem da população mundial vivendo em cidades, 1800-1950 (*)

$\begin{array}{lcc}\text { Ano } & \begin{array}{c}\text { Cidades de } 20.000 \text { ou mais } \\ \text { habitantes } \%\end{array} & \text { Cidades de } 100.000 \text { ou mais habitantes } \% \\ 1800 & 2,4 & 1,7 \\ 1850 & 4,3 & 2,3 \\ 1900 & 9,2 & 5,5 \\ 1950 & 20,9 & 13,13 \\ \text { (*) DAVIS, 1955, p.433. } & \end{array}$

Verifica-se, assim, que, enquanto no Mundo Antigo a população urbana se situava num nível de menos de dois por cento, em 1800, quando já se faziam sentir os primeiros efeitos da Revolução Industrial na Inglaterra, a porcentagem de habitantes de cidades era de uma ordem de grandeza não muito superior: 2,4 por cento da população mundial em núcleos de vinte mil ou mais. Daí em diante, porém, o crescimento da

${ }^{11}$ DAVIS, 1955 
proporção de população urbana acelera-se. Enquanto na primeira metade do século XIX essa proporção não chega a dobrar (passando de 2,4 a 4,3 por cento), de 1900 a 1950, bem mais do que duplica: 9,2 a 20,9 por cento. As metrópoles também se multiplicam: em 1800 havia cinqüenta cidades no mundo com população superior a cem mil habitantes $(1,7$ por cento da população mundial); século e meio depois, cidades daquelas dimensões somavam novecentas e incluíam 13,1 por cento dos habitantes da Terra.

Pode-se afirmar, portanto, que os séculos XIX e XX assistem a uma nova "revolução urbana", tão profunda e vasta nas transformações sociais que provoca, quanto o foi a primeira revolução urbana nos primórdios da história. Ademais, criaram-se sociedades completamente urbanizadas, ou melhor, "metropolizadas", para fazer uso de um neologismo sugestivo. Não se trata, apenas, da proporção dos habitantes que vivem em cidades ou em metrópoles. É claro que esses dados, já por si, são altamente significativos: na Inglaterra, em 1951, 38 por cento da população habitava metrópoles de mais de cem mil habitantes e 81 por cento era "urbana"12. Mais que isso, entretanto, "metropolização" significa, como, por exemplo, o demonstrou Bogue para os EUA em The Structure of the Metropolitan Community ${ }^{13}$, que as atividades econômicas e sociais, em todo o território, "organizamse" em função de sua localização relativa às metrópoles. Por outro lado, muitos outros estudos mostram quão profunda é a penetração do modo de vida urbano em toda a sociedade norte-americana, mesmo nas áreas rurais mais longínquas. $\mathrm{O}$ desenvolvimento de comunicações de massa cada vez mais intensas e insistentes, a conseqüente evolução de uma cultura popular e outras características analisadas e salientadas pelos estudiosos da sociedade de massa nos EUA $^{14}$ são parte da penetração daquele modo de vida, que se irradia a partir das grandes metrópoles norte-americanas. Criase nos EUA e nos outros países industrialmente avançados de hoje uma sociedade urbano-industrial. Saliente-se agora, nesse conceito, tratar-se de

12 Para o Brasil, em 1960, essas porcentagens eram. respectivamente, 19 e 36 por cento, considerando-se "urbana" a população dos núcleos de cinco mil ou mais habitantes.

${ }^{13}$ BOGUE, 1949

${ }^{14}$ Ver, por exemplo, a coletânea de OLSON (1963). uma sociedade em que entre todas as suas partes existe íntima solidariedade, provocada por extensa e intrincada divisão social de trabalho, e na qual as metrópoles assumem funções de "organização" do tipo das que sobressaem no estudo de Bogue; saliente-se ainda que se trata de uma sociedade em que o modo de vida urbano extravasa das metrópoles e cidades para o campo ${ }^{15}$. Em ambos sentidos, sociedade urbano-industrial é alguma coisa que se constitui. A divisão social do trabalho intensifica-se cada vez mais, atividades de dada área do território, antes autônomas, ou quase, caem sob a dependência de metrópoles, outras áreas já dependentes o ficam ainda mais, e instituições, valores e idéias, desenvolvidos nas grandes cidades, propagam-se cada vez mais completamente, e com crescente intensidade, por todos os recantos da sociedade ${ }^{16}$.

Exploremos mais detidamente as interligações entre os processos de industrialização e de urbanização e as conseqüências de ambos para $o$ desenvolvimento da sociedade urbano-industrial. Herbert Blumer, em artigo recente $^{17}$, critica a imprecisão no uso dos termos "industrialização" e "urbanização", a não-distinção entre estes processos quando se estudam os seus efeitos sociais, e o fato de não se levar na devida consideração o papel, nos efeitos identificados, de outros processos sociais ("influências do mundo externo" através dos meios de comunicação, as repercussões de leis e regulamentos, de lutas políticas, diretrizes fiscais e econômicas, etc.). Hoselitz, em um artigo que especialmente visa esclarecer certos aspectos do desenvolvimento econômico de países subdesenvolvidos, afirma também:

${ }^{15}$ É claro que não desaparecem as diferenças rurais-urbanas. O que precisa ser compreendido é que aquelas diferenças vinculam-se mais e mais estreitamente à divisão de trabalho, ao invés de derivarem de tradicionalismo local. Sobre as diferenças rurais-urbanas nos EUA, ver DONCAN, e REISS JR., 1956.

${ }^{16}$ Neste parágrafo, ficam claros os diversos sentidos que, conforme o nível da análise, damos no
ReIS. termo "urbanização". O conceito, Às vezes, serve para indicar o simples fato demográfico de proporção crescente da população passar a viver em núcleos urbanos; outras vezes, além desse fato, refere-se também à influência crescente do modo de vida urbano sobre as populações não-urbanas; finalmente, no seu sentido mais amplo confunde-se com o processo de constituição da sociedade finalmente, no seu sentido mais amplo confunde-se com o processo de constituição da socied
urbano-industrial. O sentido do conceito em cada caso fica claro pelo contexto em que se insere. ${ }^{17}$ BLUMER, 1959 
“(...) embora a industrialização e a urbanização usualmente caminhem lado a lado, não há necessariamente ligação entre os dois processos" ${ }^{\prime 18}$.

Não é uma contradição com a assertiva já feita, de que a urbanização no mundo de hoje vincula-se basicamente à Revolução Industrial, aceitar-se como parcialmente procedentes as críticas e posições desses autores. Tratase, primeiro que tudo, de uma questão de nível em que se centra a análise, se em cidades ou metrópoles determinadas, se na sociedade global. Quando é o primeiro o nosso interesse, a distinção é empiricamente necessária e de certa forma mais fácil. A fábrica moderna cria a cidade industrial. Entretanto, cidades surgem e crescem relativamente desvinculadas de uma base industrial e são muitas as outras funções - político-administrativas, recreativas, culturais, etc. - a que podem servir. Quando, porém, o enfoque recai na sociedade global, industrialização e urbanização tornam-se um único processo concreto, que passa a incluir também os outros indicados por Blumer (e que têm sido, às vezes, englobadamente, designados por "modernização"19. Os mais diversos tipos de cidades, então, preenchendo as mais variadas funções, necessitam ser vistos, para sua adequada compreensão, como partes de um mesmo sistema industrial. O modo pelo qual Waldomiro Bazzanella conceitua "modernização" nos permite precisar melhor o assunto.

Por modernização, entendemos o processo pelo qual são introduzidos numa sociedade os produtos quer materiais (bens e mercadorias), quer sociais (hábitos, valores, formas características de comportamento, enfim modos de pensar, sentir e agir) da Revolução Industrial ocorrida noutros países ou regiões, sem que esses produtos resultem diretamente de um processo interno de desenvolvimento da sociedade em questão. Nesse sentido, a industrialização de certas áreas funcionaria como fator exógeno, condicionante ou determinante, da urbanização do resto do mundo ${ }^{20}$.

\footnotetext{
${ }^{18}$ HOSELITZ, 1955, p.167.

${ }^{19}$ Ver, por exemplo, BAZZANELLA, 1963.

${ }^{20}$ Ibidem, p.6.
}

No caso do Brasil, às consequiências da industrialização da região Rio-São Paulo-Belo Horizonte (com focos industriais menores em Porto Alegre, Recife, etc.), somam-se os efeitos "modernizadores" vindos do Exterior. Somente com uma visão global como essa, do desenvolvimento do sistema industrial, pode-se compreender, por exemplo, a muito apontada "superurbanização" da América Latina ${ }^{21}$. Principalmente, quando percebemos que, como escreve Júlia J. Henderson, “(...) urbanização rápida em muitos países está ultrapassando a industrialização (...) Deste ponto de vista, a Ásia, a África e a América Latina podem todos ser denominados de continentes "superurbanizados" ${ }^{22}$. Parece-nos óbvia a necessidade de ligarse tais fenômenos a processos e sistemas, econômicos e sociais, que são mundiais no seu escopo. $\mathrm{O}$ crescimento de uma cidade ou a urbanização de uma região são vistos como partes do industrialismo em expansão. Sobre os seus alicerces erige-se uma sociedade urbano-industrial. $\mathrm{O}$ caráter de tal sociedade, a sua dinâmica no Brasil, país em desenvolvimento, é o tema do nosso estudo.

O arranjo da monografia reflete as duas ênfases aludidas atrás, ligadas às expressões "sistema industrial" e "sociedade urbano-industrial". Na primeira parte, "Desenvolvimento econômico e urbanização no Brasil", investigamos como o desenvolvimento leva a constituir-se um sistema industrial em escala nacional, com predominância econômica do Centrosul, e como a tais fatos ligam-se mudanças econômicas e demográficas em todo o país. Na segunda parte, na base das conclusões sobre aquele sistema industrial, passamos a examinar as "Transformações políticas e sociais no

${ }^{21}$ Escrevem Kingsley DAVIS e Ana CASIS: “(...) It seems to us that in view of its retarded industrialization, Latin America is Urbanized to a surprising degree. In other areas the growth of cities has arisen from large-scale industrial development, but in Latin America it has come from nonindustrial causes" (DAVIS e CASIS, 1957, p.143; nossos grifos). Segundo o ponto de vista exposto acima, essa colocação de DAVIS e CASIS é, no melhor dos casos, mal feita.

${ }_{22}$ HENDERSON, 1957, p.149. Para nós, essa formulação não é satisfatória. O crescimento de cidades no mundo subdesenvolvido, embora ocorra freqüentemente sem industrialização local, vincula-se ao industrialismo em suas dimensões mundiais. Para uma crítica da tese da "superurbanização" dos países subdesenvolvidos, sob outros pontos de vista, ver SOVANI, 1966, capítulo I. 


\section{Primeira Parte}

\section{Desenvolvimento econômico e urbanização no Brasil}




\section{I - Aspectos do desenvolvimento econômico}

Primeiramente é preciso fazer um exame do desenvolvimento econômico brasileiro e do crescimento de cidades industriais ${ }^{1}$, Procuramos inicialmente indagar do papel da constituição de "mercados internos" urbanos para o desenvolvimento industrial. Em seguida veremos como o desenrolar da industrialização processa-se no Brasil com o duplo aspecto (na verdade um só processo) de crescente concentração geográfica e de interligamento dos vários "mercados internos" num único mercado nacional. No capítulo II estudaremos, numa visão ampla e nas suas relações com o desenvolvimento econômico, a urbanização do Brasil.

\section{Urbanização e formação de "mercados internos"}

O primeiro surto industrial entre nós, que atingiu proporções significativas, coincidiu com os primeiros tempos da República², Entre as suas determinantes básicas, encontram-se:

\footnotetext{
${ }^{1}$ Valemo-nos para a caracterização sumária, no texto, da industrialização brasileira, dos autores assinalados na nota 7 da Introdução (principalmente Celso FURTADO e Ignácio RANGEL) e do estudo de SINGER, sobre a evolução econômica de São Paulo, Blumenau, Porto Alegre, Belo Horizonte e Recife. SINGER, 1968. (Este estudo de SINGER faz parte de um projeto maior sobre Desenvolvimento Econômico e Mudança Social, desenvolvido sob a direção do Prof. Florestan FERNANDES, pela Cadeira de Sociologia I da Faculdade de Filosofia, Ciências e Letras da Universidade de São Paulo, financiado por uma dotação da Confederação Nacional da Indústria àquela Cadeira.) Se o objetivo primordial fosse a compreensão do processo de desenvolvimento e não, como é, a interpretação da sociedade urbano-industrial que dele vem resultando, teríamos de procurar atingir um entendimento sócio-econômico uno, e não bastaria lançar mão de análises feitas por economistas. Fernando Henrique CARDOSO, em trabalho que procura esboçar um sistema de referência nesse sentido, escreve: “(...) no es suficiente reemplazar la interpretación 'económica' del desarrollo por un análisis 'sociológico'. Lo que se hace necesario es un análisis integrado que dé los elementos para contestar en forma más amplia y matizada los interrogantes generales sobre las posibilidades del desarrollo o estancamiento de los países latinoamericanos, así como las cuestiones decisivas sobre su sentido y sus consecuencias políticas y sociales" (CARDOSO, 1965 (a), págs. 7$8)$.

${ }^{2}$ Roberto SIMONSEN ressalta com dados a importância dessa onda de industrialização: “(...) 150 industries were founded in Brazil between 1880-1884, with a capital of 58.368,338\$000 and from
}

1. A constituição de mercados para produtos industriais importados, em algumas áreas do país, a saber, grosso modo, o da região São Paulo-Rio, na base da cafeicultura, o da Zona da Mata, ao redor do Recife (na base da economia açucareira), e o do Sul, tendo as cidades de Rio Grande e Porto Alegre por centros (na base de uma agropecuária voltada para o abastecimento interno);

2. A abolição da escravatura e a imigração européia, fatores importantes tanto para a formação de mercados internos, já referida, como para a libertação de capitais e para a constituição de uma mão-de-obra, que puderam ser aproveitadas pela indústria;

3. Medidas de proteção tarifária, e as financeiras e creditícias de dinheiro fácil, adota das pelo Governo republicano ${ }^{3}$.

Singer, no seu estudo ${ }^{4}$, analisa, em cada caso, as condições regionais de maior destaque, responsáveis pela formação dos "mercados internos" para produtos industriais. Esses mercados são inicialmente atendidos por produtos importados, para depois, no fim do século, passar a sê-lo, em parte, pelas fábricas nacionais.

A região São Paulo-Rio é claramente o caso mais importante e para a formação nela do mercado interno sobressai a economia do café. Examinemos com vagar o processo, pois nele identificaremos certas interrelações entre o desenvolvimento econômico e mudanças da economia e sociedade rurais, que mais tarde voltaremos a encontrar em nossa análise ${ }^{6}$.

1885-1889, 284 establishments with capital amounting to 203,404,521\$000 (...) Between 1890-1895, 452 factories were founded with a capital of 213,714,736\$000". SIMONSEN, 1939, p.24.

${ }^{3}$ Esses são os fatores básicos; outros também contribuíram para esse inicio da industrialização na década dos 90. Poderia ser lembrada, por exemplo, a oferta de energia. Esta é instalada para fornecer eletricidade para bondes; quando, devido à indústria, a demanda se eleva, a capacidade geradora é aumentada. Parece-nos, pois, que SINGER tem razão ao colocar tal fator como derivado. Cf. SINGER, capítulo "São Paulo", 1968.

${ }^{4}$ Ver nota 1 . Em todo o trecho que se segue, utilizamo-nos desse estudo.

${ }^{5}$ Diz-se "mercados internos", pois formam-se eles em cada zona, permanecendo por largo período relativamente estanques, mesmo após o aparecimento da indústria no Brasil. A formação de um mercado nacional é processo importante para o nosso tema e a ele voltaremos adiante.

${ }^{6}$ Ver item 2 do capítulo III. 
No campo inseriu-se sempre amplo setor de economia natural ${ }^{7}$, incluindo mesmo atividades "industriais". A fazenda satisfazia suas necessidades, como nota Ignacio Rangel, "parte com o produto de suas vendas, parte com uma produção que dentro da própria fazenda tinha seu alfa e seu omega". O mesmo autor denomina "complexo rural" à mescla de atividades de nosso agricultor, agrícolas e industriais, para o autoconsumo e para o mercado, e afirma:

O desenvolvimento econômico, em seu aspecto mais elementar, pode pois ser concebido como resultado da 'irradiação' pelo complexo rural de uma indústria após outra e da criação de 'indústrias' novas, que são fruto da divisão do trabalho, porque correspondem a necessidades que só surgem com essa divisão, a saber, especialmente, o comércio e os transportes ${ }^{8}$.

O longo período de crescimento das exportações do café contribuiu decisivamente para a dissolução do "complexo rural" na região Rio-São Paulo. Levando esse crescimento ao emprego cada vez mais completo da mão-de-obra na agricultura de exportação, provocava diminuição concomitante das atividades de economia natural, sejam as agrícolas sejam as manufatureiras. Atuou no mesmo sentido a substituição do trabalho escravo pelo livre, principalmente pelo imigrante9. Por outro lado, o

\footnotetext{
${ }^{7}$ Usamos o termo "economia natural" no sentido da história econômica, isto é, de produção para autoconsumo.

${ }^{8}$ RANGEL, 1956, págs. 111 e 87. Gilberto PAIM, em ensaio histórico inspirado em RANGEL, ilustra exaustivamente o "complexo rural" no século passado, no Brasil. Ver PAIM, 1957, especialmente págs. 18-38. No seguinte trecho toma-se clara a importância da dissolução do "complexo rural" para a industrialização: "Como as fazendas se abasteciam a si mesmas e ainda supriam as localidades próximas de produtos que deveriam provir de unidades manufatureiras situadas fora do seu âmbito, e como as cidades da costa recebiam bens industrializados de além-mar, não havia espaço na economia nacional, até o terceiro quartel do século passado, para estabelecimentos fabris propriamente ditos" (p.28).

${ }^{9} \mathrm{O}$ escravo, instrumento vivo de trabalho, achava-se totalmente fora do mercado. Uma vez investido capital nele, precisava-se empregar, o mais completamente, o seu tempo. $\mathrm{O}$ aproveitamento dessa mão-de-obra em atividades de subsistência (agrícolas ou industriais), nos períodos de menor necessidade de trabalho na agricultura de exportação, significava que aqueles bens de subsistência produziam-se, a rigor, sem custo
}

crescimento das cidades (comércio e transporte) faz-se, como assinala Rangel, em função da exportação ${ }^{10}$. Nas suas conseqüências, esses fatores convergem. Escreve Singer:

O resultado destas mudanças estruturais - expansão do setor de exportação em detrimento do de subsistência, a substituição do trabalho escravo pelo livre e a urbanização - foi a criação de um mercado interno de certa significação, abastecido principalmente por produtos importados ${ }^{11}$.

O processo de constituição noutras regiões brasileiras de mercado interno para produtos industriais importados tem o mesmo caráter: o estabelecimento de divisão social do trabalho mais nítida e complexa entre o campo e a cidade, com a perda de "indústrias" pelo "complexo rural" e a concentração na cidade de atividades de comércio, transporte, políticoadministrativas, etc. O estudo de Singer, já citado, identifica os fatores regionais de maior destaque em cada caso. No extremo-sul ${ }^{12}$ trata-se do aparecimento de agricultura e pecuária comerciais, para o abastecimento da região cafeicultora Rio-São Paulo: pecuária ao redor de Rio Grande e Pelotas, agricultura na zona de colonização alemã e italiana, tributária de Porto Alegre. Forneciam produtos de subsistência para a região de economia de exportação Rio-São Paulo e dela recebiam bens industriais importados. No caso de Recife ${ }^{13}$, o fator importante é a revolução industrial representada pela introdução da usina na economia açucareira, que passa a constituir mercado para certos bens de produção (indústria de sacaria, fundições), amplia talvez o mercado para bens de consumo ao alterar as relações de produção no meio rural e, expulsando trabalhadores para a cidade, constitui lá um reservatório de mão-de-obra fabril.

${ }^{10}$ RANGEL, 1956, págs. 93-95. A imigração contribuiu para o crescimento das cidades. Carlo CASTALDI documenta, em um estudo de grupo de imigrantes italianos em São Paulo, como esses, trazidos para a agricultura, refluem continuamente para a cidade ou mesmo não chegam a ir para o campo, "fugindo" ao desembarcar em Santos ou sendo "libertados", por parentes ou amigos, da Hospedaria dos Imigrantes. Ver CASTALDI, 1960, págs. 289-290.

${ }^{11}$ SINGER, capítulo "São Paulo", 1968.

${ }^{12}$ SINGER, capítulo "Porto Alegre", 1968.

${ }^{13}$ SINGER, capítulo "Recife", 1968. 
O aparecimento desses "bolsões" de mercado, principalmente urbano, para produtos industriais importados, nesses pontos e em alguns outros do território brasileiro, foi fundamental para a industrialização do país. Deu-se devido ao longo período de expansão de nossas exportações durante a segunda metade do século XIX. A pergunta que se impõe é por que, com o afrouxamento da demanda externa dos nossos produtos, não houve a reabsorção pelo setor de economia natural de boa parte do setor de mercado, com o conseqüente período de estagnação, como acontecera em momentos equivalentes no fím dos outros ciclos de nossa história econômica (como com o açúcar nos meados do século XVII e com o ouro no fim do século XVIII). Escreve Rangel sobre esse problema:

Se a Europa comprava menos açúcar, a fazenda tinha que reduzir suas compras de pano da 'costa' e, com os braços e recursos sobrantes da lavoura e da moenda, aumentava sua própria produção de pano. Noutros termos, a economia reagia aos movimentos do comércio exterior, da capacidade para importar, por uma substituição de importações no nível da economia natural ${ }^{14}$.

Na sua análise, porém, do ciclo do café, o mesmo autor salienta, como fatores básicos para o novo comportamento da economia em função dos movimentos do comércio exterior, primeiro, o fato de com a Abertura dos Portos (1808), "o comércio e o transporte [terem deixado] de ser atividades estritamente externas, para se tornarem, paulatinamente, "indústrias nacionais"" (ao mesmo tempo também que um setor "governo" passava a ser parte da nossa economia) e, em segundo lugar, o volume de atividades urbanas, acumulado com a longa prosperidade proporcionada pelo café. Parece-nos útil transcrever, embora longamente, o que ele diz sobre o assunto.

O aparelho comercial e os transportes, primitivamente criados para os fins do comércio exterior, quando este diminui, podem viabilizar um certo esforço de substituição de importações porque possibilitam alguma divisão de trabalho entre as fazendas das diferentes regiões e a orientação de parte dos fatores por elas empregados para atividades

${ }^{14}$ RANGEL, 1956, p.111; grifos no original. "produtivas", fazendo surgir unidades de novo tipo. É um fato histórico que nossas empresas industriais emergiam de uma gradual transformação de antigas empresas comerciais (...) [Com a expansão do comércio exterior entre 1850 e 1875] acumulou-se uma massa considerável de fatores [expandindo-se o aparelho de comércio, de transporte e de governo], os quais, quando (...) o comércio exterior voltou a entrar em crise, não puderam ser inteiramente reabsorvidos pelas unidades agrícolas e pelos serviços domésticos das famílias. Os fatores assim libertos organizaram-se em numerosas pequenas unidades, industriais, de tipo predominantemente artesanal, o que introduzia um modo novo de substituição de importações (págs. 112113; grifos no original).

Destaca-se, assim, bem claramente, para a indústria que depois se instalará, a importância da urbanização já alcançada nas últimas décadas do século passado, na capital do país, em São Paulo, nas várias cidades do Vale do Paraíba, na base do café, no Sul, em Rio Grande, Pelotas, Porto Alegre, como reflexo da economia cafeeira (abastecimento da região RioSão Paulo com produtos agropecuários), e em Recife e em outras cidades do Nordeste, em função do açúcar.

Ainda referente à constituição do mercado na região Sul do Brasil, para produtos industriais, devemos referir-nos, mesmo que brevemente, à natureza das relações de trabalho no campo. Fundamental foi a Abolição, em todo o país, com a substituição do braço escravo pelo livre. Entretanto, o caráter das relações de trabalho que se estabeleceram variou de região para região. É este assunto de grande importância, que ainda não recebeu o merecido tratamento sistemático. Em grande parte do território brasileiro, a escravidão foi substituída por relações nitidamente patrimonialistas ${ }^{15}$. Em alguns lugares, o caráter capitalista das mesmas foi desde o início mais pronunciado. As repercussões de tais fatos para o desenvolvimento de um "mercado" não podem deixar de ser das maiores. Nesse sentido o imigrante

\footnotetext{
15 Sobre a rápida acomodação do ex-escravo a formas patrimonialistas de trabalho na zona fluminense, ver Stanley J. STEIN, 1957 (a), págs. 262 e segs. A permanência nos dias de hoje de padrões patrimonialistas em município da Zona da Mata de Minas Gerais acha-se bem estudada por Oracy NOGUEIRA, O município de Leopoldina, capítulo “A zona rural”, manuscrito.
} 
foi importante para o Sul do país. Na cafeicultura paulista, depois da Abolição, ele deve ter sido relevante para o aparecimento do salariado de forma mais clara. Nas colônias de Santa Catarina e do Rio Grande do Sul, vindo de comunidades européias que se estavam articulando cada vez mais com mercados urbanos, ele não se contenta com as magras possibilidades de consumo da economia natural e, bem antes de 1888, coloca os alicerces duma economia mercanti1 ${ }^{16}$.

Na última década do século XIX, portanto, havia "áreas de mercado", mais ou menos extensas, em cidades já de certa expressão (e em uma quase metrópole, o Rio) e nas zonas rurais que lhes eram tributárias. A demanda de produtos industriais dessas "ilhas" de mercado era atendida pela importação. Os centros urbanos constituíram-se pois numa das precondições do desenvolvimento industrial posterior: a existência de mercados para produtos manufaturados. Aquele desenvolvimento, por seu turno, irá intensificar enormemente o crescimento urbano. Antes de tratar deste tópico no próximo capítulo, examinemos dois aspectos da expansão da indústria no Brasil: a sua crescente concentração geográfica e a constituição de um mercado nacional.

\section{Desenvolvimento, concentração industrial e mercado nacional}

Às tarifas alfandegárias e ao crédito fácil adotados no início da República ${ }^{17}$, somam-se a crise do comércio exterior e a diminuição da nossa capacidade de importar, propiciando o aparecimento de fábricas nacionais que passam a atender, em parte, o mercado preexistente de bens industriais. Dava-se proteção à indústria nascente, criavam-se condições de acumulação do capital, ao mesmo tempo que o funcionamento do câmbio "defendia" o nível de emprego durante a crise do comércio exterior ${ }^{18}$.

\footnotetext{
${ }^{16}$ Ver SINGER, capítulo "Blumenau”, 1968.

${ }^{17}$ Ver acima, p. 11.

${ }^{18}$ Ver a análise do mecanismo de "socialização das perdas", por FURTADO, 1959. cap. XXVIII:

"A defesa do nível de emprego e concentração da renda", págs. 191-198.
}

As indústrias que surgem são principalmente as alimentícias e têxteis, para as quais as economias resultantes de escala de produção não se fazem tanto sentir e, por outro lado, a proximidade do mercado consumidor é de grande relevância ${ }^{19}$. As condições gerais, propícias à indústria nacional, levam ao seu aparecimento em todas as cidades em que já se havia formado um mercado de alguma monta para manufaturas. São muitos os aglomerados urbanos, largamente espalhados pelo território brasileiro, que se industrializam, cada qual com o seu mercado regional quase estanque ${ }^{20}$. Devemos acompanhar desde aquele momento dois aspectos intimamente inter-relacionados do processo de industrialização: a interligação dos vários mercados formando um único mercado nacional $\mathrm{e}$ o próprio desenvolvimento industrial, por assim dizer, em profundidade, em sucessivas ondas de substituição de produtos antes importados.

Não há estudos que incidam diretamente sobre a formação de um mercado nacional, uno e integrado, processo ainda não terminado. Podemos entrevê-lo, através do exame da crescente concentração industrial. De fato, na medida em que se integram os mercados, os produtos das fábricas da zona de produção a menores custos (por gozar maiores economias externas e de escala), no caso os da área São Paulo-Rio, penetram os outros mercados e dão margem à crescente concentração industrial naquela zona.

O quadro II permite-nos apreciar essa evolução a partir de 1907.
${ }^{19}$ Estes dois ramos, por ocasião do censo de 1920, davam cerca de 66 por cento do valor da produção industrial brasileira.

${ }^{20}$ Esta forma assumida pelos processos de industrialização e urbanização no Brasil está claramente relacionada com o modo de integração da nossa economia na época ao mercado mundial. $\mathrm{Na}$ tipologia sugerida por F. H. CARDOSO, o Brasil cai no tipo I: "situaciones de subdesarrollo en las quales hay una clase económica local que mantiene el dominio del sector exportador de la economía y que, a la vez, cumple las funciones de la clase política, directora del Estado". CARDOSO, 1965 (a), p.21. Há exceções à generalização do texto de terem-se constituído no Brasil no século passado mercados estanques; a mais importante diz respeito às vinculações da economia agropecuária do extremo-sul, servindo ao mercado formado na área da cafeicultura. 
Quadro II

Distribuição percentual do valor da produção industrial por Estados, 1907, 1920, 1938 e 1958 (*)

$\begin{array}{ccccc}\text { Estado } & 1907(\%) & 1920(\%) & 1938(\%) & 1958(\%) \\ \text { Distrito Federal } & 33,1 & 20,8 & 14,2 & 11,4 \\ \text { São Paulo } & 16,5 & 31,5 & 43,2 & 55,0 \\ \text { Rio Grande do Sul } & 14,9 & 11,0 & 10,7 & 7,7 \\ \text { Rio de Janeiro } & 6,7 & 7,4 & 5,0 & 6,6 \\ \text { Paraná } & 4,9 & 3,2 & 1,8 & 3,1 \\ \text { Minas Gerais } & 4,8 & 5,5 & 11,3 & 5,6 \\ \text { Pernambuco } & 4,0 & 6,8 & 4,2 & 2,8 \\ \text { Bahia } & 3,2 & 2,8 & 1,7 & 1,5 \\ \text { Pará } & 2,7 & 1,1 & 0,7 & 0,6 \\ \text { Amazonas } & 2,0 & 0,1 & 0,2 & 0,3 \\ \text { Santa Catarina } & 2,0 & 1,9 & 1,8 & 2,1 \\ \text { Alagoas } & 1,0 & 1,6 & 0,7 & 0,5 \\ \text { Maranhão } & 0,7 & 0,7 & 0,3 & 0,2 \\ \text { Sergipe } & 0,6 & 1,2 & 0,6 & 0,2 \\ \text { Mato Grosso } & 0,5 & 0,2 & 0,2 & 0,3 \\ \text { Ceará } & 0,4 & 0,8 & 0,9 & 0,6 \\ \text { Paraíba } & 0,4 & 1,1 & 0,8 & 0,6 \\ \text { Goiás } & 0,2 & 0,1 & 0,2 & 0,3 \\ \text { Piauí } & 0,1 & 0,2 & 0,1 & 0,1 \\ \text { Rio Grande do Norte } & 0,1 & 0,6 & 0,4 & 0,3 \\ \text { Espírito Santo } & 0,1 & 0,7 & 0,2 & 0,2 \\ \text { Total } & 100,0 & 100,0 & 100,0 & 100,0 \\ \text { *) JOBIM, 1943, p.96, e Produção industrial brasileira, 1958. } & \end{array}$

Desde o início, nota-se a concentração da indústria no então Distrito Federal e em São Paulo. (quase metade do valor da produção total). Isso se deve a estar aí o maior mercado interno do país ${ }^{21}$. O fato a sublinhar no

\footnotetext{
${ }^{21}$ O então Distrito Federal, sendo o maior mercado urbano do Brasil, cerca de 700.000 habitantes em 1900, concentra naturalmente a maior parte da nova indústria. O fato de o Rio de Janeiro perder a sua vantagem inicial e ser ultrapassado pela cidade de São Paulo, contra o que seria de esperar pelos pressupostos teóricos da economia, é analisado por SINGER (capítulo "São Paulo", 1968), que acha que os fatores básicos foram o deslocamento, para o nosso Estado, do mercado consumidor
}

início do século, entretanto, é a relativa dispersão industrial pelo Brasil a fora. Depois do Distrito Federal, de São Paulo e do Rio Grande do Sul, que avultam bem a frente dos outros Estados no desenvolvimento industrial, nada menos que oito têm apreciável parcela do total (mais de 2 por cento). São eles: Rio de Janeiro, Paraná, Minas Gerais, Pernambuco, Bahia, Pará, Amazonas e Santa Catarina. As cidades em desenvolvimento industrial são, principalmente, as capitais, mas incluem também, entre outras, Itu, Campinas, Sorocaba, Rio Grande, Pelotas, Juiz de Fora, Blumenau e Brusque.

Durante todo este século, interligam-se os mercados regionais, formando-se um mercado nacional. O que cabe assinalar no momento é que à medida que isso se dá, acentua-se a hegemonia da indústria paulista e, em menor grau, da carioca. Em 1938, São Paulo e o Distrito Federal têm mais de 57 por cento do valor total da produção; em 1958 essa porcentagem ultrapassa 66 por cento. Neste último ano, oito unidades da federação têm mais de 2 por cento de produção (comparadas com onze em 1907). Noutras palavras, as indústrias paulista e carioca passam a crescer não só em função do aumento de seu mercado interno regional, mas também na dependência do nacional que se forma. (Essa concentração - é claro - não se dá uniformemente em todos os ramos industriais: é tão mais forte quanto mais importante para o ramo forem economias de escala e menor o for a proximidade do mercado, isto é, ela é mais intensa para a indústria mecânica, de material de transporte, etc., menos para a de bens de consumo.)

Nos períodos de aceleração da industrialização, o processo de constituição do mercado nacional intensifica-se e beneficia-se a região industrial hegemônica. $\mathrm{O}$ desenvolvimento industrial brasileiro caracterizou-se desde o início, como vimos, por ser um processo de substituição de importações ${ }^{22}$. A indústria brasileira desenvolveu-se nos

constituído pela zona cafeicultora e o fato de a rede de transporte de toda essa zona, já no período final do século, enfeixar-se no eixo São Paulo-Santos.

${ }^{22}$ Como de resto o é a industrialização de todos os países em desenvolvimento, na periferia do capitalismo, neste século. 
períodos de crise do comércio exterior (1. ${ }^{\mathrm{a}}$ Guerra Mundial, depressão dos anos 30, 2. ${ }^{a}$ Guerra Mundial), quando the foram criadas condições favoráveis de proteção (a própria situação de guerra em 1914-18 e 1939-45; a crise mundial juntamente com a política de defesa do café nos anos $30^{23}$ ), às quais somava-se uma política também favorável à acumulação do capital $^{24}$.

Condições e políticas favoráveis à industrialização redundam em última instância em benefício da região mais rica em recursos e de maior grau de desenvolvimento, aumentando assim as disparidades regionais e a concentração industrial. Uma única ilustração, tirada do estudo do Grupo de Trabalho para o Desenvolvimento do Nordeste, será suficiente. Argumentase nesse trabalho que a rápida industrialização do Centro-sul no pós-guerra teve, inter alia, dois suportes básicos: os subsídios cambiais e os financiamentos governamentais. A análise de um e outro leva à conclusão de que "essa política de amplos subsídios ao setor industrial contribuiu para concentrar os investimentos no Centro-sul do país"; isso por dois motivos principais, entre outros: por estarem os industriais do Centro-sul melhor aparelhados para justificar pedidos de licença de importação e para exercer pressão junto às autoridades competentes, e por ocorrerem vantagens, decorrentes do caráter da tecnologia moderna, de se investir na parte do país onde a mão-de-obra é relativamente mais cara ${ }^{25}$.

Industrializa-se o Brasil, formando-se o mercado nacional e concentrando-se a indústria no Centro-sul. Vejamos como essa feição do processo de industrialização afeta a urbanização.

${ }^{23}$ Ver sobre este ponto a análise de FURTADO (1959, nos capítulos XXXI e XXXII: "Os mecanismos de defesa e a crise de 1929" e "Deslocamento do centro dinâmico", págs. 217-236).

${ }^{24}$ Ver FURTADO, 1964, págs. 113-118, em que analisa a "Interação dos processos acumulativo e inflacionário". Outras políticas, além das que analisa, como a salarial durante 1947-50, atuaram também no sentido de intensificar a acumulação do capital.

${ }^{25}$ Grupo de Trabalho para o Desenvolvimento do Nordeste, 1959, págs. 56-57.

\section{II - O processo de urbanização}

Sobre a urbanização, que já havia ocorrido pelos anos finais do século XIX, erige-se a indústria; esta, por sua vez, toma o crescimento urbano mais intenso, Examinaremos agora dados sobre a urbanização brasileira e o crescimento de cidades específicas, para a seguir voltar a discutir as inter-relações entre os desenvolvimentos urbano e industrial. As conclusões a que chegaremos nos permitirão proceder, com vagar, à análise da urbanização da área adiantada e da área atrasada do Brasil.

\section{Contornos gerais do processo}

No quadro III apresentam-se dados sobre o grau de urbanização no Brasil, de 1872 a 1960, medido, em cada ano, pelo número de cidades com mais de cinqüenta mil, cem mil e meio milhão de habitantes e pela população que as habitava. Uma advertência faz-se desde logo necessária: os dados do censo de 1920 e anteriores não são, a rigor, comparáveis aos de 1940 a 1960. Somente a partir de 1940 se começou a separar a população das cidades e vilas (quadros urbano e suburbano) da rural do mesmo município. Assim, fomos obrigados a nos utilizar, para os quatro primeiros censos (1872 a 1920), das populações totais dos municípios com cinqüenta mil habitantes ou mais, enquanto para os três últimos (1940 a 1960) tomamos os dados mais exatos, que excluem a população rural do município. $\mathrm{O}$ erro é maior, é claro, para as cidades menores (afetando mais, portanto, a coluna das de cinqüenta mil habitantes ou mais), pois para as maiores a parcela rural é proporcionalmente bem menor.

Vemos que em 1872 cerca de 6 por cento da população estava em cidades de mais de cinqüenta mil habitantes (Rio, Salvador, Recife e São Paulo, nessa ordem); só as três primeiras possuíam população maior que cem mil e nenhuma alcançara o marco do meio milhão. Em 1960, tínhamos perto de 23 por cento da população em aglomerados urbanos de cinqüenta mil habitantes ou mais; tais aglomerados eram em número de 73, 31 dos quais com mais de cem mil habitantes, e seis dentre eles tendo atingido mais de meio milhão de habitantes. O ritmo da urbanização nos últimos vinte anos (1940-1960) é especialmente impressionante. Enquanto a população total cresce no período pouco mais de 70 por cento, tanto a população de cidades com mais de cinqüenta mil habitantes como a das de 
mais de meio milhão mais que triplicam. Em 1960, os habitantes das grandes metrópoles (as de mais de quinhentos mil habitantes) eram quase duas vezes mais numerosos do que os que estavam em todas as cidades de população com cinqüenta mil habitantes ou mais em 1940 (9 comparados com 5,2 milhões).

Quadro III

Grau de urbanização do Brasil, 1872-1960 (*)

\begin{tabular}{|c|c|c|c|c|c|c|c|c|c|c|}
\hline \multirow[t]{2}{*}{ Censo } & \multirow[t]{2}{*}{$\begin{array}{l}\text { População } \\
\text { total }\end{array}$} & \multicolumn{2}{|c|}{$\begin{array}{l}\text { Cidades com } \\
50.000 \\
\text { habitantes ou } \\
\text { mais }\end{array}$} & \multicolumn{3}{|c|}{$\begin{array}{c}\text { Cidades com } \\
100.000 \text { habitantes } \\
\text { ou mais }\end{array}$} & $\begin{array}{c}\text { Cidades com } \\
500.000 \\
\text { habitantes ou mais }\end{array}$ & \multicolumn{3}{|c|}{ População urbana \% } \\
\hline & & $n$ & População & $n$ & População & $n$ & População & $\begin{array}{c}50.000 \\
\text { ou }+\end{array}$ & $\begin{array}{c}100.000 \\
\text { ou }+\end{array}$ & $\begin{array}{c}500.000 \\
\text { ou }+\end{array}$ \\
\hline 872 & 8 & 4 & 582.749 & 3 & 520.752 & - & - & 5 & & - \\
\hline 1890 & 14 & 6 & 97 & 3 & & - & 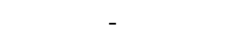 & 6 , & 5, & - \\
\hline 1900 & .438 .434 & 8 & 1.644 .149 & 4 & 1.370 .182 & - & - & 9,4 & 7,9 & - \\
\hline & & 15 & & 6 & & 1 & $\sigma$ & 10 & & \\
\hline 194 & 236.315 & 22 & 5.216 .070 & 10 & 4.413. & 2 & 2.777 .492 & 12,6 & 10,7 & 6,7 \\
\hline 195 & & 33 & 8.48 & 11 & 6.873 & 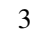 & & 16 & 13,2 & 9,3 \\
\hline 1960 & 70.967 .185 & 73 & 16.260 .851 & 31 & 13.309 .463 & 6 & 9.068 .200 & 22,9 & 18,8 & 12,8 \\
\hline
\end{tabular}

(*) Nos censos de 1872 a 1920 os dos referem-se a populações dos municípios das capitais que tinham em cada caso população maior que os limites especificados; nos anos de 1940 a 1960 , trata-se da população de cidades ou vilas (quadros urbanos e suburbanos) com mais do que os mesmos limites.

Fonte: Dados censitários.

$\mathrm{O}$ quadro IV, referente ao crescimento percentual melhor o desenvolvimento da urbanização. Constatamos por ele como o crescimento da população das cidades (e das metrópoles), durante todo o período, faz-se num ritmo mais rápido do que o da população total ${ }^{1}$.

${ }^{1}$ Há distorções grandes na taxa de crescimento da população brasileira entre 1900-20 e 1920-40, devido às falhas dos censos de 1900 e 1920, principalmente os erros por excesso deste último. Análises cuidadosas efetuadas pelo Laboratório de Estatística do IBGE levaram à "verificação de um sensível erro por falta no resultado total do censo de 1900 e de um notável erro por excesso no do censo de 1920..." (Laboratório de Estatística, 1951, p.62). As últimas colunas do quadro IV, onde figuram as relações entre o crescimento urbano e o total, em cada período, são talvez menos afetadas por tais erros.
Ademais, o ritmo de urbanização acompanha, grosso modo, as ondas de desenvolvimento industrial descritas acima ${ }^{2}$. Intensifica-se, fortemente, na década 1890-1900 (atingindo mais de três vezes o crescimento da população global), para voltar a um nível pouco mais baixo nas primeiras décadas deste século e intensificar-se de novo a partir de 1940 (próximo a duas vezes e meia o aumento da população total). (Devido à mudança de critério apontada acima, não nos é possível dizer o que ocorreu com o crescimento urbano nos anos 30, quando se verificou, como vimos, significativa industrialização.)

\section{Quadro IV}

Crescimento percentual médio por ano da população total e da urbana, Brasil,

$$
\text { 1872-1960 }
$$

\begin{tabular}{|c|c|c|c|c|c|c|c|}
\hline \multirow[b]{2}{*}{ Período } & \multicolumn{4}{|c|}{ Crescimento anual médio } & \multicolumn{3}{|c|}{$\begin{array}{l}\text { Relação entre o } \\
\text { crescimento urbano }\end{array}$} \\
\hline & $\begin{array}{l}\text { População } \\
\text { total (\%) } \\
\text { (1) }\end{array}$ & $\begin{array}{c}\text { Cidades de } \\
50.000 \text { ou } \\
\text { mais (\%) (2) }\end{array}$ & $\begin{array}{l}\text { Cidades com } \\
100.000 \text { habitantes } \\
\text { ou mais }(\%)(3)\end{array}$ & $\begin{array}{l}\text { Cidades com } \\
500.000 \text { habitantes } \\
\text { ou mais }(\%)(4)\end{array}$ & $(2) /(1)$ & $(3) /(1)$ & $(4) /(1)$ \\
\hline $\begin{array}{c}1872- \\
1890\end{array}$ & 2,5 & 3,7 & 3,1 & - & 1,5 & 1,2 & - \\
\hline $\begin{array}{c}1891- \\
1900\end{array}$ & 2,2 & 6,8 & 6,9 & - & 3,2 & 3,2 & - \\
\hline $\begin{array}{c}1901- \\
1920\end{array}$ & $3,8(*)$ & 5,0 & 4,8 & - & 1,3 & 1,3 & - \\
\hline $\begin{array}{l}1921- \\
1940\end{array}$ & $1,7(* *)$ & $(* * *)$ & $(* * *)$ & $(* * *)$ & $\ldots$ & $\cdots$ & $\cdots$ \\
\hline $\begin{array}{l}1941- \\
1950\end{array}$ & 2,6 & 6,3 & 5,6 & 7,4 & 2,4 & 2,2 & 2,9 \\
\hline $\begin{array}{l}1951- \\
1960\end{array}$ & 3,7 & 9,2 & 9,4 & 8,8 & 2,5 & 2,5 & 2,4 \\
\hline
\end{tabular}

*) Provavelmente exageradamente alto (ver nota 1 ao texto)

(**) Provavelmente exageradamente baixo (ver nota 1 ao texto).

$(* * *)$ Ver nota ao quadro III e texto (p.22).

Fonte: Dados censitários.

Nota-se ainda, no último decênio do século passado, um grau de urbanização que é praticamente o mesmo, seja nas cidades maiores, seja nas

${ }^{2}$ Lembremo-nos que essas ondas se verificam na década de 1890-1900, em 1914-18, na década dos anos 30, em 1939-45 e ainda com maior intensidade a partir dos anos 50. 
menores (pouco inferior a 7 por cento ao ano). As cidades de maior crescimento, então como agora, eram as industriais, e essas, naquela época, incluíam metrópoles com população superior a cem mil habitantes (Rio de Janeiro e Recife), como outras com menos habitantes (São Paulo, Porto Alegre, e outras), cujo desenvolvimento industrial não era menor.

A situação nos últimos decênios, como revelada pelo quadro, é bem mais confusa. O número de cidades em cada categoria é grande e entre elas estão algumas com industrialização pronunciada, junto com outras com bem menor desenvolvimento industrial, ou mesmo nenhum. A proporção de umas e de outras, assim como o nível de crescimento que acusam entre 1940 e 1950, afetam o aumento médio da categoria durante o período.

Estudo mais minucioso revela melhor as relações entre a industrialização e o crescimento urbano nas décadas recentes. Waldomiro Bazzanella analisou o crescimento urbano, a parte desse devida ao do setor secundário (indústria de transformação) e a que se deve ao do setor terciário ("serviços") ${ }^{3}$, entre 1940 e 1950, referente às 141 cidades que na primeira data possuíam mais de dez mil habitantes ${ }^{4}$. No quadro V apresentamos esses dados separadamente, segundo o grau de industrialização (medido pela porcentagem da população em 1940 na indústria de transformação).

Vê-se por esse quadro que cresceram mais as cidades mais industrializadas: 60 por cento as de mais de 15 por cento de industrialização (para as de menos de 7 por cento, aquela porcentagem foi de apenas 32). $\mathrm{O}$ mesmo quadro revela-nos também que, do crescimento urbano naquele decênio das cidades mais industrializadas, mais de 55 por cento foi absorvido pelo crescimento dos setores secundário e terciário, sendo uma boa parte pelo primeiro ( 26 por cento); enquanto nas menos industrializadas só 48 por cento do crescimento urbano foi absorvido pelo aumento daqueles setores (apenas 10 por cento pelo secundário). Vemos, portanto, que,

\footnotetext{
${ }^{3}$ No setor terciário incluem-se as pessoas, de 10 anos ou mais, empregadas nos ramos: comércio de mercadorias, comércio de móveis, transportes e comunicações, administração pública, defesa nacional e segurança pública, profissões liberais, serviços e atividades sociais.

${ }^{4}$ BAZZANELLA, 1963
}

enquanto a urbanização se processa em ritmo mais rápido nas cidades industriais, as que não são industriais também estão crescendo e o estão fazendo mais rapidamente do que a população total (que se elevou de cerca de 25 por cento entre 1940 e 1950). O crescimento dessas últimas cidades, entretanto, ocorre com uma parcela maior de desocupação e sub-ocupação. Este último fato expressa-se na elevada proporção do aumento urbano que é incorporado ao setor terciário ( 38 por cento comparados com menos de 30 para as cidades mais industriais $)^{5}$. Isso está a indicar que o crescimento urbano nas regiões mais adiantadas do Brasil faz-se com características distintas do que se processa nas menos adiantadas. A questão vai merecer maior atenção de nossa parte.

Quadro V

Crescimento dos setores secundário (indústria de transformação) e terciário

("serviços") em relação ao crescimento urbano, segundo o grau de industrialização das cidades, 1940-1950

$\begin{array}{ccccc}\begin{array}{c}\text { Grau de industrialização das } \\ \text { cidades em 1940(*) }\end{array} & \begin{array}{c}\text { Crescimento urbano } \\ 1940-1950(\%)\end{array} & \text { em relação ao crescimento urbano, 1940-1950 } \\ & & s / u \% & t / u \% & u \\ & & & s+t \\ \text { Até 7\% } & 32,1 & 10,3 & 38,0 & 48,3 \\ \text { 8 a 15 } & 48,5 & 12,7 & 33,3 & 46,0 \\ \text { + de 15 } & 60,0 & 25,6 & 29,6 & 55,2 \\ \text { Total } & 49,1 & 16,6 & 32,6 & 49,2 \\ \text { (*) Porcentagem da população urbana empregada na indústria de transformação. }\end{array}$

(*) Porcentagem da população urbana empregada na indústria de transformação. Fonte: Dados de BAZZANELLA, 1963, págs. 24 e 25.

\section{A urbanização nas regiões adiantadas e nas atrasadas}

As consequiências da indústria para o crescimento urbano são diversas no início do desenvolvimento industrial brasileiro e nos últimos

\footnotetext{
5 Amplo setor terciário é característico das sociedades desenvolvidas (CLARK, 3. ${ }^{\text {a } e d i c ̧ a ̃ o, ~ 1957, ~}$ capítulos IX e X); entretanto ocupações tais como as de empregados domésticos, vendedores ambulantes, etc., classificadas também no terciário, aparecem em alta proporção nas cidades das regiões subdesenvolvidas. O setor terciário tem natureza diversa em um e outro caso.
} 
decênios. Na década de 1890 a 1900, a: indústria surge em muitos pontos do Brasil, gozando em cada qual de um mercado regional, e neles provoca um rápido aumento da população urbana (operariado, população empregada em "serviços", etc.). De lá para cá, constitui-se um mercado nacional e o desenvolvimento industrial subseqüente concentra-se crescentemente na região Centro-sul (Rio - São Paulo - Belo Horizonte). O crescimento das cidades industriais continua a ser mais intenso do que as demais. Entretanto, não há concentração geográfica da urbanização equivalente à que se verifica na indústria. Pelo contrário, as cidades em crescimento espalham-se por ampla orla de norte a sul do Brasil. A rigor elas não crescem, e sim "incham", aumentando a sua população em clara desproporção às oportunidades de emprego.

Este fato não significa um desligamento dos processos de industrialização e urbanização. É que se está constituindo, com o mercado nacional, um sistema industrial, tomando não só intimamente solidárias as mais dispersas partes da sociedade, como também irradiando por toda ela um modo de vida urbano criado nas metrópoles, isto é, com os efeitos a que já chamamos de "modernização". É o sistema industrial, com tais características, que é responsável pela forma como se vem dando a urbanização brasileira no período recente ${ }^{6}$. $\mathrm{O}$ crescimento de grande número de cidades independe do aparecimento nelas de indústrias e passam a decorrer de um lado das mudanças na economia rural, que se fazem em função das mudanças de todo o sistema econômico, e do outro, do "efeito de demonstração", propiciado pela nova sociedade que surge (comunicações de massa, crescente mobilidade da população, enfraquecimento das relações patrimonialistas, etc.).

Examinemos, porém, em ordem, as diversas afirmações já feitas; as primeiras duas ainda neste capítulo, deixando a última para o seguinte. São elas:

1. No período recente, ao passo que as disparidades de desenvolvimento industrial crescem, as de ritmo de urbanização diminuem.

\footnotetext{
${ }^{6}$ Ver, porém, nota 20 do capítulo anterior.
}

2. Resulta, então, nas cidades de crescimento industrial mais fraco, ampla proporção de desempregados ou subempregados.

3. Essa urbanização depende dos efeitos indiretos, econômicos e sociais, da industrialização nas áreas mais dinâmicas do país.

Sobre a primeira afirmação, acrescentemos apenas alguns dados sobre as cidades de São Paulo, Recife e Porto Alegre, três das principais entre as que iniciaram sua industrialização no fim do século passado. $\mathrm{O}$ quadro VI fornece dados sobre o seu crescimento urbano.

Quadro VI

Crescimento de São Paulo, Recife e Porto Alegre, 1872-1960

\begin{tabular}{|c|c|c|c|}
\hline \multirow{2}{*}{ Ano } & \multicolumn{3}{|c|}{ População (*) } \\
\hline & São Paulo & Recife & Porto Alegre \\
\hline 1872 & 31.385 & 116.671 & 43.998 \\
\hline 1920 & 579.033 & 238.843 & 179.263 \\
\hline 1960 & 3.825 .351 & 797.234 & 641.173 \\
\hline Períod & \multicolumn{3}{|c|}{ Taxa geométrica de crescimento anual } \\
\hline Perloao & São Paulo $(\%$ & Recife (\%) & Porto Alegre (\%) \\
\hline $872-1920$ & 6,3 & 1,5 & 3,0 \\
\hline 1920-1960 & 4,8 & 3,1 & 3,2 \\
\hline
\end{tabular}

(*) Dados para os municípios das três capitais.

Fonte: Dados censitários.

Nota-se perfeitamente que, ao invés de aumentarem, diminuem as diferenças de ritmo de crescimento urbano. No primeiro período, até 1920 , São Paulo cresce numa taxa mais de quatro vezes a de Recife e mais do dobro da de Porto Alegre, Esse ritmo de urbanização reflete o desenvolvimento muito mais rápido de sua indústria. Entretanto, nos últimos quarenta anos, embora a industrialização de São Paulo continue ainda mais intensa do que a das duas outras cidades, o seu crescimento urbano é pouco mais que uma vez e meia o das outras.

O que ocorre no caso dessas três cidades está acontecendo por todo o Brasil. A indústria concentra-se, mas, com a constituição do sistema industrial em escala nacional, alastra-se o processo de urbanização.

Quanto à segunda assertiva sobre a conseqüente "inchação" das cidades não ou pouco industrializadas, há quase completa ausência de dados 
versando diretamente o fenômeno. Assim, somos obrigados a recorrer a indicações indiretas sobre o mesmo, encontradiças no censo de 1950.

Uma tabulação especial feita para os municípios de São Paulo, Belo Horizonte e Salvador, cruzando a ocupação da população de 10 anos ou mais pelo ramo de atividade em que é exercida em 1950, nos dá indicadores valiosos da extensão de subemprego e desemprego, nessas cidades ${ }^{8}$.

Como indicação de desemprego, tomamos o número de pessoas "inativas", e como de subemprego o. das pessoas em nove categorias ocupacionais em determinados ramos de atividade: como por exemplo "jardineiros", "lavadeiras", etc., no ramo "prestação de serviços"; "vendedores ambulantes", no de "comércio de mercadorias"; e "trabalhadores braçais sem especialização", no de "transportes, comunicações e armazenagem"

No quadro VII, onde se encontram sumariados esses dados, podemos ver que em São Paulo as ocupações indicadoras de subemprego atingiam a 6,6 por cento da força de trabalho, os quais, somados a 9,5 por cento de inativos, davam um total de 16,1 por cento para essas categorias em 1950. Para Belo Horizonte esta porcentagem era de 27,4 (12,9\% de inativos e $14,5 \%$ nas nove ocupações assinaladas); e, para Salvador, era de 32,1 por cento $(14,6 \%$ e $17,5 \%$, respectivamente, para aquelas duas parcelas). Não há dúvida de que essas porcentagens são apenas indicativas e devem só servir para comparar uma cidade com outra e nunca num sentido absoluto.

\footnotetext{
${ }^{7}$ Os dados equivalentes do censo de 1960 não haviam sido publicados.

${ }^{8}$ Essa tabulação acha-se publicada nos volumes do censo, para as unidades da federação. Conseguimos que nos fossem fornecidas as tabulações para as três capitais aludidas, pelo que agradecemos ao Serviço Nacional de Recenseamento.

9 "Condições inativas" incluem, além de "sem ocupação e desempregados", várias outras categorias, tais como os que vivem de renda, os aposentados, os inválidos e os detentos. Entretanto, a grande maioria do total é constituída pelos desempregados; para o Estado de Minas Gerais, por exemplo, os desempregados são mais de 75 por cento dos "inativos" A lista completa das ocupações indicadoras de "subemprego" no ramo "prestação de serviços" inclui jardineiros, lavadeiras, engraxates, sapateiros, cozinheiras, costureiras, bordadeiras e serzideiras.
}

Assim, a cidade de São Paulo, onde as oportunidades de emprego são mais abundantes, tem, provavelmente, nessas categorias, uma das menores proporções no país. Para ela, "os inativos" incluem talvez muito maior proporção das outras categorias, exceto a de desempregados (ver nota 9) do que no Estado todo, onde esses eram próximos de dois terços dos "inativos" $\left.{ }^{10}\right)$. Por outro lado, é claro que nem todos os que estão nas nove ocupações enumeradas podem ser considerados como "subempregados". Este termo deve ser entendido em sentido relativo. Alta proporção de pessoas nessas ocupações, relativamente a que nelas se encontram em São Paulo $^{11}$, indicaria correspondentemente nível alto de subemprego. Em outras palavras, a "inchação" dessas ocupações é tomada como indicação do estado de subemprego em geral na cidade. Parece-nos altamente significativo, por exemplo, que aquelas nove ocupações (entre mais de duzentas categorias ocupacionais em que se acha dividida no censo a população) incluíam mais de 1/6 da força de trabalho de Salvador em 1950, 1/7 da de Belo Horizonte, e apenas 1/15 da de São Paulo; que São Paulo, na data daquele censo, com seis vezes a força de trabalho de Salvador e sete vezes a de Belo Horizonte, não chegasse a ter o dobro de cozinheiras, lavadeiras e engomadeiras daquelas cidades (25.665 comparados com 14.600 e 15.304$)$.

\footnotetext{
${ }^{10}$ Um levantamento da força de trabalho em São Paulo (com amostra estratificada de 2.313 domicílios), feito em dezembro de 1953, por serviço da Secretaria do Trabalho de São Paulo, acusou 1,7 por cento de desempregados. Tomou-se, entretanto, para estudo, as pessoas maiores de 14 anos, que trabalham mediante remuneração ou lucro, ou estilo à procura de trabalho. No censo a base é constituída pelas pessoas com 10 anos ou mais e os "desempregados" incluem, portanto, alta percentagem de menores, entre 10 e 14 anos, que não estão em escolas, nem trabalhando. Sobre o levantamento mencionado, ver Serviço de Pesquisas do Mercado de Trabalho, 1954, págs.4-14.

${ }^{11}$ Outra indicação do nível de subemprego relativamente baixo na capital paulistana (que entretanto
Onamento mencionado, ver Serviço de Pesquisas do Mercado de Trabalho, 1954, págs.14. ninguém afirmaria ser inexistente) nos é dado pelo mesmo levantamento já citado: apenas 6,4 por cento (5,0 por cento para os homens e 9,7 por cento para as mulheres) dos "empregados" (todos que tenham ocupação remunerada ou lucrativa) haviam trabalhado menos de 30 horas na semana-base. Como seria de se esperar, a grande maioria desses estavam fora da indústria: apenas 2,1 dos que aí estavam trabalharam menos de 30 horas, comparados com 10,6 dos que estavam em outros ramos. Idem, págs. 11 e 12
} 
Com base nos dados para essas três cidades podemos ver que o melhor sinal de subemprego, quando se dispõe apenas da classificação por atividade (como é o caso das informações censitárias para as outras cidades brasileiras), é a proporção da força de trabalho feminina no ramo "prestação de serviços". Na verdade, essa proporção subestima as diferenças existentes quanto ao subemprego, como esse é indicado por aquelas ocupações.

\section{Quadro VII}

Subemprego e inatividade em três cidades brasileiras, 1950

"Subemprego"

7 ocupações (*) (prestações de

$$
\text { serviços)... }
$$

Vendedor ambulante (comércio de mercadorias)

Trabalhadores braçais sem

especialização (transportes) Total

População ativa + inativos

Inativos

"Subemprego"

7 ocupações $(*)$ (prestações de serviços)...

Vendedor ambulante (comércio de

Trabalhadores braçais sem especialização (transportes) Total

População ativa + inativos Inativos

"Subemprego"

\section{7 ocupações $(*)$ (prestações de
serviços)...} serviços)...

mercadorias)

Trabalhadores braçais sem

especialização (transportes)$$
\text { Total }
$$

População ativa + inativos

"Subemprego"

\begin{tabular}{|c|c|c|c|c|c|c|}
\hline \multicolumn{2}{|c|}{$\begin{array}{c}\text { São Pa } \\
\text { Homens }\end{array}$} & \multicolumn{2}{|c|}{ Mulheres } & \multicolumn{3}{|c|}{ Total } \\
\hline$N$ & $\begin{array}{l}\% \text { do } \\
\text { ramo }\end{array}$ & $N$ & $\begin{array}{l}\% \text { do } \\
\text { ramo }\end{array}$ & $N$ & & $\%$ do ramo \\
\hline 6.620 & 6,9 & 43.850 & 45,0 & 50.470 & & 26,0 \\
\hline 13.166 & 12,2 & 583 & 4,0 & 13.749 & & 11,2 \\
\hline 5.476 & 9,7 & - & - & 5.476 & & 9,2 \\
\hline 5.262 & & 44.433 & & 69.695 & & \\
\hline 769.608 & 100,0 & 279.521 & 100,0 & 1.049 .129 & & 100,0 \\
\hline 73.894 & 6,6 & 25.791 & 9,2 & 99.685 & 9,5 & $9,5+6,6$ \\
\hline 25.262 & 3,3 & 44.433 & 15,9 & 69.695 & 6,6 & 16,1 \\
\hline
\end{tabular}

\section{Belo Horizonte}

\begin{tabular}{|c|c|c|c|c|c|c|}
\hline 1.124 & 8,8 & 18.041 & 72,6 & 19.165 & & 50,9 \\
\hline 1.955 & 14,0 & 112 & 5,4 & 2.067 & & 12,9 \\
\hline 673 & 6,9 & - & - & 673 & & 6,2 \\
\hline 3.752 & & 18.153 & & 21.905 & & \\
\hline 102.472 & 100,0 & 48.199 & 100,0 & 150.671 & & 100,0 \\
\hline 13.676 & 13,3 & 5.789 & 12,0 & 19.465 & 12,9 & $12,9+14,5$ \\
\hline 3.752 & 3,7 & 18.153 & 37,6 & 21.905 & 14,5 & $27,4 \%$ \\
\hline \multicolumn{7}{|c|}{ Salvador } \\
\hline 2.318 & 14,6 & 20.967 & 72,7 & 23.285 & & 52,1 \\
\hline 4.215 & 21,6 & 828 & 27,1 & 5.043 & & 22,3 \\
\hline 2.573 & 17,2 & - & - & 2.573 & & 16,6 \\
\hline 9.106 & & 21.795 & & 30.901 & & \\
\hline 123.277 & 100,0 & 53.492 & 100,0 & 176.769 & & 100,0 \\
\hline 17.489 & 14,2 & 8.280 & 15,5 & 25.769 & 14,6 & $14,6+17,5$ \\
\hline & & 21.795 & 40,7 & 30.901 & 175 & $-321 \%$ \\
\hline
\end{tabular}

(*) São as seguintes: "jardineiros”, “engraxates”, “sapateiros”, "lavadeiras”, “cozinheiras”, "costureiras" e "bordadeiras e serzideiras" (todas do ramo "prestação de serviços").

Fonte: Tabulações especiais de dados do Censo.

De fato, as porcentagens da força de trabalho feminina para Salvador, Belo Horizonte e São Paulo, em "prestação de serviços", são, respectivamente, 55, 52 e 35 por cento. Não contando, porém, as pessoas naquelas sete ocupações, as proporções restantes no ramo passam a ser, respectivamente, 13, 14 e 19 por cento, isto é, tanto maiores quanto mais oportunidades econômicas existem na cidade (ao invés de como era para o ramo total). Tendo este fato em mente, examinemos a repartição da força de trabalho nas capitais dos Estados pelos vários ramos de atividade (quadro VIII) ${ }^{12}$. Nesse quadro dividimos as cidades pelo tamanho e segundo se situem em Estados "atrasados" ou "adiantados", conforme o seu produto per capita fosse em 1947 inferior ou superior à média nacional ${ }^{13}$.

Examinemos primeiro a parte referente às mulheres, onde as tendências são mais visíveis. Vemos que as mais altas porcentagens em "prestação de serviços", parcela do terciário, encontram-se nas cidades maiores da região atrasada. Nas menores dessa região, embora esse índice de subemprego seja ainda relativamente alto, sobressaem mais as taxas altas em "condições inativas" (indicativas de desemprego). As cidades dos Estados relativamente mais adiantados apresentam porcentagens menores em "prestação de serviços" e "condições inativas", ao passo que acusam maiores porcentagens na parte "indústria" do setor secundário ${ }^{14}$. As

\footnotetext{
${ }^{12}$ Examinamos apenas as capitais dos Estados das regiões Nordeste, Leste e Sul que incluem a maior parte da população brasileira, assim como toda área de algum grau de urbanização. A limitação a

essas regiões será seguida sem exceção em todas as partes deste trabalho.
${ }_{13}$ Dados da Fundação Getúlio Vargas. Ver, também, BAER, 1964, págs. 268-285.

${ }^{14}$ Separamos, no setor secundário, a parte referente a pessoal de fábrica (indicados no texto e no quadro VIII como efetivos de "indústria') das pessoas que são realmente operários de pequenas oficinas ou artesãos, seja por conta própria, seja como trabalhadores em domicílio (indicados naquele quadro como "outros '). Utilizamo-nos para isso de um artifício. Como "indústria" colocamos os dados. para 1951, do inquérito econômico da Secretaria Geral do Conselho Nacional de Estatística (ver Anuário Estatístico do Brasil, 1962, p.164), inquérito que abrangeu os estabelecimentos
} 
tendências na parte referente aos homens, se observarmos com cuidado, são no mesmo sentido.

\section{Quadro VIII}

Distribuição percentual da força de trabalho urbana (a), masculina e feminina, pelos vários componentes, capitais estaduais, 1950

\section{Homens}

\begin{tabular}{|c|c|c|c|c|c|c|}
\hline Capitais estaduais & $\begin{array}{c}\% \text { de homens na força } \\
\text { de trabalho humana }\end{array}$ & $\begin{array}{l}\text { Setor secu } \\
\text { "Indústria" } \\
\quad(b)\end{array}$ & $\begin{array}{l}\text { Indário } \\
\text { Outros } \\
\text { (b) }\end{array}$ & $\begin{array}{l}\text { Setor terct } \\
\text { Prestação } \\
\text { de serviços }\end{array}$ & $\begin{array}{l}\text { iário } \\
\text { Outros }\end{array}$ & Inativos \\
\hline \multicolumn{7}{|l|}{$\begin{array}{c}\text { Estados atrasados } \\
(\text { (c) }\end{array}$} \\
\hline \multicolumn{7}{|l|}{$\begin{array}{l}\text { Com mais de } \\
100.000 \text { hab. }\end{array}$} \\
\hline Recife & 69,0 & 14,9 & 8,9 & 12,4 & 43,1 & 20,8 \\
\hline Salvador & 68,3 & 10,4 & 13,2 & 13,9 & 47,1 & 15,4 \\
\hline Belo Horizonte & 67,3 & 12,2 & 13,9 & 13,0 & 47,0 & 13,9 \\
\hline Fortaleza & 69,6 & 7,6 & 11,8 & 12,8 & 47,2 & 20,6 \\
\hline \multicolumn{7}{|l|}{ Com menos de } \\
\hline Maceió & 65,5 & 10,5 & 7,5 & 10,1 & 37,9 & 24,4 \\
\hline Natal & 74,1 & 3,1 & 12,2 & 9,6 & 49,4 & 25,7 \\
\hline João Pessoa & 67,2 & 5,6 & 13,1 & 9,3 & 42,6 & 29,4 \\
\hline São Luís & 67,8 & 7,6 & 14,1 & 12,2 & 43,6 & 22,5 \\
\hline Aracaju & 66,4 & 6,0 & 18,6 & 11,6 & 44,9 & 18,8 \\
\hline Teresina & 70,7 & 1,1 & 19,0 & 12,8 & 37,6 & 29,6 \\
\hline Vitória & 70,5 & 8,6 & 6,3 & 13,5 & 56,4 & 15,2 \\
\hline $\begin{array}{l}\text { Estados médios e } \\
\text { adiantados }(c)\end{array}$ & & & & & & \\
\hline
\end{tabular}

industriais localizados nos municípios das capitais que tiveram, no ano anterior ao levantamento movimento total de vendas não-inferior a duzentos mil cruzeiros. A categoria "outros" é resultado da subtração desse total para "indústria" do número assinalado no censo para os que trabalhavam em indústria de transformação. Assim, obtém-se como "indústria" estimativa mais fiel do pessoal empregado em produção propriamente fabril. No caso das mulheres, os efetivos em "outros" são quase sempre pequenos, e mesmo às vezes negativo. Este fato reflete, a nosso ver, duas coisas: 1) que a quase totalidade das mulheres, ocupadas no setor secundário, ao contrário dos homens, estão mesmo em fábricas, e 2) que para elas o levantamento do inquérito econômico, realizado a partir das declarações dos estabelecimentos, é às vezes mais completo que o feito a partir do censo demográfico de 1950 (quando muitas, que trabalhavam apenas meio tempo, indicaram como sua atividade principal a doméstica). Sobre este último ponto, ver MORTARA, 1956, págs. 108-109.
Com mais de $100.000 \mathrm{hab}$. Rio de Janeiro (d) São Paulo (e) Porto Alegre Porto Alegre Com menos de 100.000 hab. Florianópolis 73,8 73,2
71,2
75,2 


\section{Mulheres}

Setor secundário Setor terciário

"Indústria" (b) Outros (b) Prestação de serviços Outros

Inativos

Capitais estaduais

Estados atrasados (c) Com mais de 100.000 hab. Recife
Salvador Belo Horizonte

Fortaleza

Com menos de 100.000 hab

$\begin{array}{cccccc}\text { Maceió } & 19,1 & 1,1 & 40,1 & 18,0 & 21,8 \\ \text { Natal } & 1,0 & 1,9 & 55,6 & 17,9 & 23,5 \\ \text { João Pessoa } & 6,7 & -4,6 & 43,4 & 20,1 & 34,3 \\ \text { São Luís } & 14,3 & 0,7 & 40,5 & 20,2 & 24,4 \\ \text { Aracaju } & 17,2 & 0 & 47,0 & 23,1 & 12,6 \\ \text { Teresina } & 0,5 & 1,0 & 41,7 & 22,3 & 34,5 \\ \text { Vitória } & 6,1 & -2,4 & 53,6 & 30,1 & 12,6\end{array}$

Estados médios e adiantados (c)

Com mais de 100.000 hab.

Rio de Janeiro (d)

São Paulo (e)

Porto Alegre

Curitib

Com menos de 100.000 hab.

Florianópolis

$\begin{array}{ccccc}16,4 & -1,8 & 46,2 & 26,3 & 12,9 \\ 40,0 & -1,7 & 33,5 & 18,5 & 9,6 \\ 15,1 & -1,8 & 43,7 & 27,8 & 15,2 \\ 18,0 & -1,4 & 36,5 & 30,5 & 16,4 \\ & & & & \\ 7,4 & 3,2 & 34,1 & 32,7 & 22,5\end{array}$

(a) População ativa urbana (setores secundário e terciário) mais condições inativas;

(b) Separou-se o setor secundário em duas parcelas: em "indústria" Inclui-se o pessoal dos estabelecimentos industriais com uma produção de valor mínimo de $\operatorname{Cr} \$ 200,00$ e em "outros", a diferença que falta para o total referente à indústria de transformação, segundo o censo (ver nota 14).

(c) Segundo o Produto per capita em 1947 era maior ou menor que a média nacional

(d) Inclusive Niterói.

(e) Inclusive os municípios de Santo André, São Bernardo do Campo e São Caetano do Sul.

Fonte: Dados censitários e Inquérito Econômico da Secretaria Geral do Conselho Naciona de Estatística (Anuário Estatístico, 1952).

Grosseiras como são essas estatísticas, elas servem como indicação do grau de desemprego e subemprego nas cidades brasileiras, de como ambos tendem a variar em relação inversa ao emprego na "indústria" (talvez o melhor sinal do desenvolvimento das oportunidades de emprego), e, ainda, de como a situação das cidades menores das regiões mais pobres parece mais grave do que a das maiores (caracterizando-se mais claramente por desemprego do que por subemprego, como essas últimas).

Esse último ponto pode ser corroborado com dados do estudo de Bazzanella, em que já nos apoiamos, sobre a absorção pelos setores secundário e terciário do aumento de população urbana, entre 1940 e 1950, nas 141 cidades com mais de dez mil habitantes em 1940. Ele divide os Estados em atrasados, moderadamente adiantados, e adiantados ${ }^{15}$, e analisa aquela absorção segundo o tamanho da cidade.

Note-se, primeiro, no quadro IX, a constância da taxa de incorporação do aumento urbano naquela década ao setor terciário: ao redor de um terço. Entre as principais exceções, assinalam-se as cidades menores de cinquienta mil habitantes nos Estados atrasados (com 20 a 22 por cento). São elas também que incorporam naquele período a menor proporção à indústria de transformação (secundário): ao redor de 4 a 5 por cento. Isso significa uma incorporação do aumento urbano aos setores secundário e terciário da ordem de 25 a 26 por cento (enquanto as porcentagens correspondentes nas cidades do mesmo tamanho na região adiantada são superiores a 50 por cento). Este fato está a indicar um largo desemprego nas pequenas cidades daquelas regiões.

O subdesemprego nos Estados atrasados denuncia-se mais pelo aumento exagerado do setor terciário, fato que parece transparecer quando se comparam as estatísticas referentes à proporção do aumento incorporada a esse setor nas cidades maiores daqueles Estados com o mesmo dado para os adiantados ${ }^{16}$.

15 Essa divisão baseou-se em vários critérios (Informações sobre a população urbana e rural, analfabetismo, renda per capita, etc.) e não coincide com a que fizemos acima. Entre os Estados "atrasados" acham-se incluídos todos os das regiões Norte, Nordeste (com exceção de Pernambuco), Centro-Oeste e o de Espírito Santo. Nos "moderados" incluem-se Pernambuco, Bahia e Minas Gerais. Entre os "adiantados", os restantes. BAZZANELLA, 1963, p.7.

${ }^{16}$ As porcentagens referentes à incorporação do aumento aos dois setores, no caso das cidades de cinquienta a cem mil habitantes dos Estados "moderados", parecem elevadas em demasia, fugindo às tendências gerais reveladas pelo quadro. Tratando-se de apenas três Estados, suspeitamos que haja pequeno número de cidades que neles caem dentro daquele tamanho, e os índices apresentados 
Quadro IX

Incorporação do aumento urbano, entre 1940 e 1950, nos setores secundário e terciário, segundo o tamanho das cidades e o adiantamento dos Estados (*)

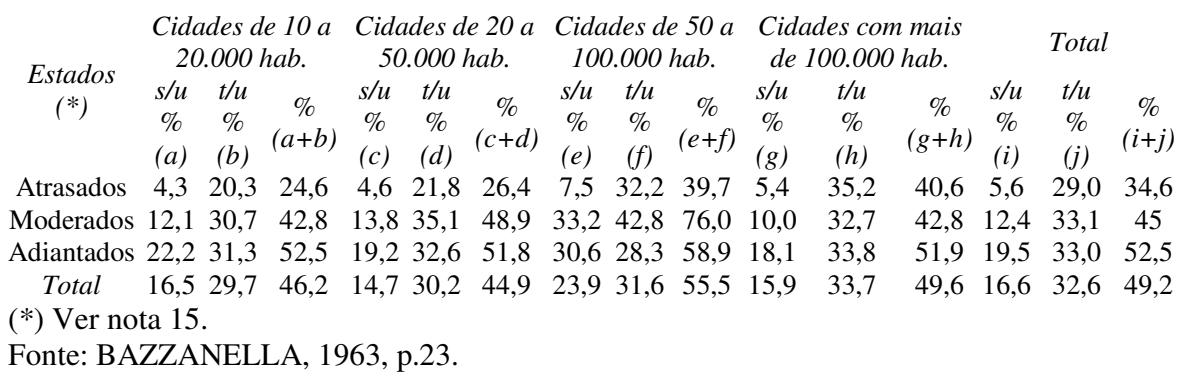

Fonte: BAZZANELLA, 1963, p.23.

Entretanto, deve-se notar que o setor terciário reúne ocupações com tendências divergentes face à industrialização. Nele estão vendedores ambulantes, biscateiros, empregados domésticos de toda a ordem, engraxates, trabalhadores por conta própria em insignificante comércio, artesãos, etc., ocupações essas características do subdesenvolvimento. Por outro lado, aí também se incluem as atividades modernas de serviços, os empregados de escritório, grandes empresas comerciais e os funcionários da burocracia do Estado moderno. Com o desenvolvimento sócio-econômico diminuem as primeiras ocupações, enquanto se ampliam as últimas. Esses fatos escondem-se, em boa parte, nas estatísticas globais sobre o setor terciário, como as do quadro em exame.

Evidencia-se melhor a "inchação" do setor terciário das cidades dos Estados atrasados, com uma re-elaboração dos dados desse quadro. No quadro $\mathrm{X}$ calculou-se o número de pessoas que se incorporou ao setor terciário, no aumento urbano daquele período, por pessoa que entrou no secundário.

Sobressai do quadro, no período considerado, a enorme expansão das ocupações do setor terciário relativamente ao secundário, nas cidades dos

talvez revelem condições muito peculiares. Preferimos, portanto, na ausência de mais dados, fazer a comparação das duas regiões extremas, a dos Estados "atrasados" com os "adiantados".
Estados atrasados: nelas, para cada pessoa adicionada à indústria de transformação, mais do que 5 avolumaram as fileiras do terciário, em veemente indício de largo subemprego (para Estados moderados e adiantados esse índice foi, respectivamente, inferior a 3 e a 2). A proporção mais alta é encontrada nas maiores cidades, as de mais de cem mil habitantes da área atrasada, onde para cada indivíduo incorporado ao secundário corresponderam 6,5 ao terciário!

\section{Quadro X}

Número de pessoas que entrou no setor terciário por pessoa que se incorporou ao secundário, entre 1940 e 1950, por tamanho de cidade e adiantamento dos Estados (*)

\begin{tabular}{|c|c|c|c|c|c|}
\hline Estados & $\begin{array}{l}\text { Cidades de } 10 \text { a } \\
20.000 \text { hab. }\end{array}$ & $\begin{array}{l}\text { Cidades de } 20 \text { a } \\
50.000 \text { hab. }\end{array}$ & $\begin{array}{l}\text { Relaçao ts } \\
\text { Cidades de } 50 \text { a } \\
100.000 \text { hab. }\end{array}$ & $\begin{array}{c}\text { Cidades de mais de } \\
100.000 \text { hab. }\end{array}$ & Total \\
\hline & 4,7 & 4,7 & 4,3 & 6,5 & 5,2 \\
\hline & 2,5 & 2,5 & 1,3 & 3,3 & \\
\hline lian & 1,4 & 1,7 & 0,9 & 1,9 & 1,7 \\
\hline
\end{tabular}

(*) Ver nota 15

Fonte: Dados do quadro IX.

Constata-se, por conseguinte, um processo de urbanização em amplas regiões do país, em boa parte independente de qualquer desenvolvimento industrial verificado nas cidades que nelas se localizam. A consequiência é que os efetivos desocupados e sub-ocupados aumentam constantemente. Há maiores indícios de desemprego nas cidades menores, enquanto nas metrópoles o subemprego evidencia-se com mais clareza,

A consideração dos determinantes mais gerais dessa urbanização sem industrialização, e dos mecanismos envolvidos em tais fenômenos, leva-nos novamente à análise do sistema industrial em formação, com a predominância do Centro-sul, matéria do nosso próximo capítulo ${ }^{17}$.

\footnotetext{
17 Nesse capítulo voltamos a atenção para os fatores que, devido à concentração da parte industrializada do país, produzem efeitos diferenciais sobre a urbanização das várias regiões. Há,
} 


\section{III - Conseqüências da concentração do desenvolvimento no \\ Centro-sul}

Faz-se agora mister discutir, com mais vagar, a terceira afirmação feita acima, no sentido que a urbanização sem industrialização local está em clara dependência dos efeitos indiretos, econômicos e sociais, da industrialização nas áreas mais dinâmicas do país. Em outras palavras, é a constituição do sistema industrial em escala nacional (com a emergência já apontada do mercado nacional $)^{18}$ que explica aquele tipo de urbanização. Discutamos esse tópico, dividindo-o em duas partes: primeiro, os aspectos mais especificamente econômicos dos efeitos da industrialização da região dinâmica, o que, vale dizer, a sua incidência sobre as oportunidades de trabalho das regiões menos desenvolvidas ${ }^{19}$; e, segundo, a difusão nelas de

porém, forças econômicas gerais - conforme análise de Celso FURTADO - atuando no sentido de incrementar o subemprego e o desemprego em todas as cidades brasileiras, seja qual for 0 desenvolvimento da área em que se localizem. Decorrem da tendência à sobremecanização de nossas empresas. Essa tendência é, em parte, provocada pelo verdadeiro subsídio, implícito na política cambial do governo, à importação de equipamentos, e, em parte, é inerente ao caráter da tecnologia absorvida pela nossa economia dos países adiantados. "Em consequiência" ajunta FURTADO - "os grandes investimentos industriais realizados no Brasil, entre 1950 e 1960, em nada contribuíram para modificar a estrutura ocupacional da população. Com efeito, entre esses dois anos a ocupação manufatureira cresceu a uma taxa de 2,8 por cento, vale dizer, inferior ao crescimento da população e menos da metade do crescimento da população urbana. Desta forma, o crônico subemprego de mãode-obra agravou-se extremamente, numa fase de rápido crescimento da produção...” Também relevantes para FURTADO para compreensão da rapidez e forma da urbanização brasileira estão o incremento do mercado de serviços criado pela alta concentração de renda e um processo circular pelo qual as aglomerações urbanas "exigem obras públicas importantes, e um crescimento mais que proporcional do aparelho administrativo estatal, o que, por seu lado, contribui para intensificar o processo de urbanização", FURTADO, 1965, págs. 133-134 e 139-140.

${ }^{18}$ A organização político-administrativa é parte integrante do sistema industrial que se constitui, e será tratada nos capítulos V e VI.

${ }^{19}$ Há, é claro, outros efeitos econômicos, sobre as poupanças e a formação de capital. Atraídos pelas perspectivas mais amplas de lucros no Sul, as poupanças do restante do país sofrem uma drenagem (na qual o sistema bancário e, como já se apontou, as políticas de industrialização adotadas têm papel relevante). Essa tendência, nos anos mais recentes, foi em parte contrabalançada pelos investimentos governamentais nas regiões menos desenvolvidas, em montante maior do que os recursos nelas captados. No texto, no entanto, não se trata desses fatos, porque se vinculam à urbanização com atitudes, normas e valores urbanos ("modernização"), condicionante importante do êxodo rural-urbano e dos movimentos inter-regionais de população. Esses assuntos acham-se tratados nos vários tópicos em que se subdivide este capítulo: a agricultura; o artesanato; as migrações interregionais; e o processo de modernização.

\section{A agricultura}

A formação do mercado nacional afeta de maneira intensa as atividades agropecuárias de largas e distantes áreas rurais. É difícil dar um quadro completo, com o pouco conhecimento que ainda se tem do Brasil rural e das transformações nele em curso. Limitamo-nos a tratar de duas regiões - o extremo-sul e o Nordeste. Mostramos o modo pelo qual foram elas afetadas pelo mercado urbano-industrial formado na região Centro-sul e pelo aparecimento aí, para abastecê-lo, de uma agropecuária em moldes mais nitidamente comerciais.

Vimos atrás que no final do século passado constituíra-se uma série de "ilhas" de mercado no território brasileiro, três das quais destacavam-se sobre as demais: a da região cafeicultora, a das zonas de colonização no Sul (com produtos da agropecuária para abastecimento da primeira região) e a da Zona da Mata nordestina (com a economia do açúcar). Com base nesses mercados estanques para produtos industriais é que, quando surgem condições de industrialização, aparece a indústria nas cidades dessas regiões em substituição à importação de produtos manufaturados. Com a progressiva industrialização do país e lenta constituição do mercado em escala nacional, concentra-se a indústria em estreita área dos Estados de São Paulo, Minas e Rio. Ao mesmo tempo, com o afastamento do café para o oeste de São Paulo e, depois, além dos rios Paranapanema e Paraná, para o norte do Paraná e dentro do Mato Grosso, passa a constituir-se uma agricultura e pecuária comerciais, próximas da região urbano-industrial dominante.

industrialização da área dinâmica e agora o assunto em pauta é a "inchação" das cidades no resto do país. 
Singer, num trabalho recente sobre a agricultura na Bacia ParanáUruguai, assim resume as suas conclusões:

Afastada a competição do café [em São Paulo e em Minas, a terra] será utilizada [para o abastecimento do mercado de São Paulo-Rio], aproveitando as vantagens de sua localização. Eis porque surge agora em São Paulo, e em menor grau, em Minas, a segunda agricultura capitalista do país. Expande-se a criação de bovinos em São Paulo, que atrai à sua área de influência a pecuária de Minas (em parte), Goiás e Mato Grosso.. Por outro lado, desenvolve-se a cultura de cereais (arroz e milho) e de feijão, com grande ímpeto (...). Desta forma delineia-se a especialização regional da agricultura da Bacia. Ao Paraná cabe o café. A São Paulo, Minas, Goiás e Mato Grosso (e ao Paraná em certa medida) o abastecimento de São Paulo-Rio.

Desse mercado, está sendo expulso "quase por inteiro" o produto da agropecuária gaúcha ${ }^{20}$.

Esse trabalho considera que o alijamento do Rio Grande do Sul do abastecimento da região São Paulo-Rio principiou a ocorrer, principalmente, a partir de $1955^{21}$. Entretanto, um estudo de Nicholls sobre as relações em São Paulo entre as mudanças na agricultura e a evolução urbano-industrial, durante a década 1940-1950, já observa para aquela época ${ }^{22}$ que "o desenvolvimento industrial-urbano em São Paulo estava exercendo grande impacto (via os mercados de capital e de trabalho) sobre a estrutura, a renda e a produtividade da agricultura mais próxima, comparada com a daquelas partes do Estado, localizadas em zonas que usufruíram pouco crescimento industrial-urbano"23. Exame mais detalhado das conclusões de Nicholls revelam não apenas a existência, em 1939/40,

\footnotetext{
${ }^{20}$ SINGER, 1963 (b), págs. 153 e 154

${ }^{21}$ Idem, p.152.

${ }^{22}$ Enquanto SINGER se utiliza de estatísticas globais para cada Estado da Bacia, NICHOLLS analisa exaustivamente em São Paulo, através de índices de correlação, as mudanças da agricultura e o crescimento urbano-industrial, por zonas (em número de 23) do Estado. Esse maior detalhe de análise explica ter-lhe sido possível perceber num período anterior o início das modificações que se processam na agropecuária paulista.

${ }^{23}$ NICHOLLS, 1962, p.218.
}

nas zonas urbano-industriais de São Paulo, de agricultura e pecuária mais comercializadas que nas demais, mas também, para estas últimas, entre 40 e 50, a expansão da agropecuária comercial, com a conseqüente diminuição da vantagem relativa das zonas adiantadas do Estado ${ }^{24}$.

A crescente comercialização da agropecuária paulista e das áreas que lhe são tributárias (Goiás, Mato Grosso), próximas do mercado, é, pois, um dos principais fatores responsáveis pela decadência, que vem de decênios, da economia agrícola das colônias do Vale do Guaíba no Rio Grande do $\mathrm{Sul}^{25}$. Além do aumento da concorrência externa, a agricultura do Vale enfrenta também outros problemas, em parte resultantes daquele fator externo (o qual provoca queda relativa dos preços reais), quais sejam o esgotamento do solo e a proliferação de minifúndios. Disso tudo provém o persistente êxodo rural $^{26}$, em boa medida desvinculado do desenvolvimento das oportunidades de trabalho no meio urbano. Enquanto o crescimento industrial se amortece, isso absolutamente não acontece com o ritmo de urbanização ${ }^{27}$.

\footnotetext{
${ }^{24}$ Ibidem, págs. 219-246.

${ }^{25}$ Escreve SINGER: “A queda relativa dos preços reais dos produtos agrícolas do Rio Grande do Sul só se pode explicar pela entrada no mercado de novos concorrentes com certas vantagens, que se resumem possivelmente numa localização mais próxima dos grandes centros consumidores urbanos". SINGER, capítulo "Porto Alegre", 1968. Sobre a decadência rio-grandense ver, também, F. DE OLIVEIRA, 1960.

${ }^{26}$ Calcula-se em cerca de 122.000 pessoas a perda de população das colônias do Vale, desde o início do século, para as cidades, para as terras virgens e para fora do Estado. SINGER, capítulo "Porto Alegre", 1968

${ }^{27}$ Sobre o ritmo de crescimento de Porto Alegre, ver os dados já apresentados no quadro VI, à p.20. Por outro lado, vê-se que o produto real da indústria no Rio Grande do Sul cresceu, entre 1938 e 1957, 61 por cento, valor bem menor que o para o total do Brasil (112 por cento). Dados de SINGER, capítulo "Porto Alegre", 1968. Outras informações relevantes dizem respeito à população das "malocas" de Porto Alegre, calculada para 1949 em 18.000 pessoas, 45 por cento das quais nascera em zonas rurais (estatística que subestima a procedência rural por referir-se a toda a população, inclusive crianças, e não apenas a adultos ou chefes de família). Ver MEDEIROS, 1951. Sobre o processo de urbanização no Rio Grande do Sul, inclusive para dados sobre o crescimento em 1950-60 de todas as cidades com mais de cinco mil habitantes, ver MEDEIROS, 1964, págs. 69-87.
} 
No caso da economia rural nordestina há processo equivalente. O mercado dos seus principais produtos - a cana e o algodão - passa em escala crescente, já no início do século, de externo para interno, isto é, para abastecimento, antes de tudo, da região urbano-industrial Rio-São Paulo. Desde bem antes, a crescente concorrência da produção externa a menores custos (açúcar de cana das Antilhas e Filipinas; açúcar de beterraba da Alemanha) ocasionara uma revolução industrial na economia açucareira da Zona da Mata, A usina vinha progressivamente substituindo os antigos engenhos ${ }^{28}$, sem conseguir de todo vencer o seu atraso tecnológico. A partir dos anos 20, soma-se a essa situação a expansão da indústria açucareira no Centro-sul, particularmente em São Paulo. O estabelecimento do sistema de quotas pelo Governo Federal em 1932 protege a indústria do açúcar nordestino: essa subsiste estagnada. Ainda naquela década, o desenvolvimento da cotonicultura paulista agrava os problemas da economia rural do Nordeste.

Para os dois produtos, a região passa a ter o seu principal mercado dentro do país (com crescente concorrência dos produtos sulistas), enquanto no mercado externo atua como fornecedor marginal, crescendo quando a conjuntura favorável permite a penetração do produto de alto custo.

Para o nosso interesse principal no momento, qual seja o das oportunidades de trabalho no campo e na cidade, pode-se acompanhar as consequiências, inter alia, desses fatos, sob dois ângulos: o das poucas perspectivas de industrialização das cidades do Nordeste e o da expulsão do camponês da terra. A. constituição da economia nacional leva à

\footnotetext{
${ }^{28}$ SINGER, em cujo estudo de Recife nos estamos apoiando, embora com algumas mudanças de ênfase e de interpretação, fornece-nos os seguintes dados sobre o aparecimento da usina em Pernambuco: até 1885 havia 10 no Estado; entre 1885 e 1900 surgiram lá 49 novas usinas; em 1918 o total do Estado alcançava 54 usinas (e 215 em todo o país). O processo de implantação da usina então ainda estava incompleto: entre 1912-1918 apenas metade da produção de açúcar provinha de usinas. SINGER, capítulo "Recife", 1968. Aspectos sócio-econômicos dessa passagem do engenho para a usina, no Recôncavo, durante a década de 1950, acham-se analisados por H. HUTCHINSON, 1957, em particular o capítulo 9.
}

concentração da indústria no Sul, onde as economias externas são maiores ${ }^{29}$ e, com a vigorosa concorrência da agricultura sulista à economia rural do Nordeste, restringe-se ainda mais a base econômica da sua indústria e, por conseguinte, as suas possibilidades de expansão.

Por outro lado, a penetração da usina em terras dos antigos engenhos resulta na substituição de foreiros, "condiceiros" e moradores por assalariados, e na expulsão de trabalhadores para as cidades, processo que, segundo Singer, ocorre "durante toda a revolução industrial do açúcar"’30.

Deve ter havido, todavia, momentos em que circunstâncias solicitavam a expansão da produção marginal de açúcar que era e é a do Nordeste, com a conseqüente intensificação daquelas mudanças. $\mathrm{O}$ fim do século XIX e o inicio do presente deve ter sido um desses momentos (ver nota 11). Outro, como apontam Correa Andrade e Furtado, foram os anos 50. Furtado assinala que nesse período recente, com o incremento do consumo nacional de açúcar e o mercado mundial favorável, a produção nordestina aumentou de 50 por cento. Resultou dai grande diminuição do setor de economia natural encravado na açucareira; os "condiceiros" e foreiros foram obrigados a ceder os pequenos tratos de terra, onde

\footnotetext{
${ }^{29}$ Está-se considerando o momento em que a indústria nordestina já é mais fraca que a do Sul, basicamente porque o mercado sobre o qual se erigira era menor (devido à medida em que a população rural estava imersa em uma economia natural, e à baixa capacidade aquisitiva dos que estavam no setor de mercado, fosse urbano ou rural). Notamos então que, naquele momento, a crescente concorrência da agricultura do Sul à do Nordeste limita ainda mais as possibilidades de crescimento do mercado para as suas fábricas.

30 SINGER, capítulo "Recife", 1968. No presente decênio, porém, o processo ainda não se completara. Em entrevista com o autor desta monografia, em meados de 1962, o gerente de usina das proximidades de Recife declarou ter sido feito lá a substituição de foreiros por assalariados somente nos dois anos anteriores. "Quando se entregam" - explicou - "terras aos moradores, estes as cultivam sem atender aos interesses da usina. Quando admoestados, pedem a conta e deixam a usina. Por isso, nenhuma outra usina da zona entrega terras a morador para cultivar. As que têm foreiros, os estão mandando embora".
} 
produziam bens de subsistência, para atender ao aumento do plantio da cana; e avolumaram-se as levas de gente rural à procura das cidades ${ }^{31}$.

Análise recente das migrações para Recife ${ }^{32}$ chega às estimativas do saldo anual constantes do quadro XI. Por elas se percebe a acentuação do fluxo migratório depois de 1940, e ainda mais no período recente, quando atinge mais de 12.000 pessoas por ano. Duas amostras da população de Recife, estudadas como parte do mesmo projeto, permitem-nos avaliar os provindos da Zona da Mata em mais de dois terços do total de migrantes ${ }^{33}$, da Zona da Mata, onde o progresso das plantações de cana destrói gradualmente a economia de autoconsumo dos camponeses e provoca a fuga para a cidade.

\section{Quadro XI}

Estimativa do saldo das migrações para o Recife, 1920-1958

\begin{tabular}{ccccc} 
Anos & \multicolumn{4}{c}{ População (milhares) } \\
& Recenseada & Estimada & Saldo das migrações & Saldo anual \\
1920 & 238,8 & - & - & - \\
1940 & 348,4 & 271,4 & 77,0 & 3,85 \\
1950 & 524,7 & 411,0 & 113,7 & 11,37 \\
1958 & 733,9 & 622,0 & 111,9 & 12,43
\end{tabular}

${ }^{31}$ FURTADO, 1964, 2. a parte, capítulo 2, especialmente págs. 139-155. Ver também 'M. C. ANDRADE, 1963, págs. 109-110.

${ }^{32}$ A. C. GONÇALVES, 1961, p.9.

${ }^{33}$ Lacerda de MELO, 1961, págs. 43-47. A primeira amostra aludida apurou o lugar de nascimento dos pais (ou responsáveis) de crianças matriculadas nos grupos escolares de Recife (total: 4.655 casos). Na segunda, o dado refere-se a 4.684 famílias de diversas áreas urbanas de habitações pobres. As porcentagens das duas amostras de migrantes vindos da Zona da Mata de Pernambuco foram, respectivamente, 62,6 e 58,7 por cento. Muitos vieram entretanto da mesma zona de Estados limítrofes, e deveriam ser adicionados. O exame cuidadoso dos municípios com altos índices de emigração revela (como assinala SINGER em seu estudo, obra citada) que se trata daqueles onde a usina ainda não predomina, mas é de penetração recente. Devem-se ajuntar que pesquisa realizada em 1959 das migrações para Salvador, embora feita com dados precários, chega à conclusão de que provém do Recôncavo a porcentagem mais elevada de migrantes e aponta entre as suas causas "a desorganização da antiga estrutura agrária" (ver Milton SANTOS, 1963, págs. 126-150). Embora o autor desse artigo não mencione a penetração da usina, ela estava efetivamente se dando naquela área, como o demonstra a pesquisa de H. HUTCHINSON (nota 11, supra).
(*) "As estimativas são feitas baseadas nos resultados dos censos anteriores, supondo-se que a população prossiga na mesma tendência do período intercensitário anterior".

Fonte: GONÇALVES, 1961, p.9.

\section{Em Recife, como escreve Lacerda de Melo,}

(...) o crescimento urbano faz-se sem correspondência com o desenvolvimento das atividades e funções urbanas ou, em outras palavras, sem correspondência com a ampliação do dinamismo funcional urbano (...) Expressão desse fato na paisagem urbana é o número de mocambos aqui existentes. Segundo estimativas atuais, atingem 80 a 100 mil essas habitações pobres ou miseráveis, o que significa abrigarem cerca de metade da população da cidade. Em 1939 , eram $45.531 .^{34}$

A análise desses casos - o do Rio Grande do Sul e o de Pernambuco - mostra-nos, em suma, que a constituição da economia nacional é o pano de fundo necessário para se compreender a urbanização sem industrialização, com as características cidades "inchadas" que se notam nas áreas menos desenvolvidas do Brasil, mormente no Nordeste.

\section{2. $O$ artesanato}

A emergência gradual do mercado em escala nacional, além de provocar O êxodo rural, torna-se responsável pelo desaparecimento do artesanato nessas áreas, aumentando ainda mais o descompasso entre a demanda e as oportunidades de trabalho nelas existentes. Sem surgirem no volume necessário novos empregos urbanos, contraem-se além disso as ocupações artesanais.

Um levantamento do artesanato no Nordeste, realizado há cerca de dez ou doze anos por pesquisadores do Banco do Nordeste ${ }^{35}$, fornece-nos estimativas dos efetivos nos vários Estados e ramos (quadro XII).

\footnotetext{
${ }^{34}$ Lacerda de MELO, 1961, p.33.

${ }^{35}$ Banco do Nordeste do Brasil S. A., 1958. A pesquisa cobriu os principais pontos de concentração do artesanato nordestino. Os autores assim caracterizam o artesanato: “(...) resolveu-se neste trabalho
} 
Quadro XII

Estimativa do emprego no artesanato do Nordeste por localização e atividades

$\begin{array}{cccccc}\text { Atividades } & \text { Ceará } & \text { Bahia } & \text { Outros }\left(^{*}\right) & N & \% \\ \text { Cestaria e trançados } & 40.000 & 5.000 & 1.500 & 46.500 & 55,6 \\ \text { Bordados e congêneres } & 20.000 & 1.500 & 300 & 21.800 & 26,1 \\ \text { Tecelagem manual } & 1.500 & 4.000 & 800 & 6.300 & 7,5 \\ \text { Charutos e cigarros } & 60 & 6.000 & - & 6.060 & 7,2 \\ \text { Joalheria e ourivesaria } & 1.300 & 300 & - & 1.600 & 1,9 \\ \text { Cerâmica } & 100 & 200 & 400 & 700 & 0,8 \\ \text { Artefatos de metal } & 200 & 180 & - & 380 & 0,5 \\ \text { Artefatos de couro } & - & 300 & - & 300 & 0,4 \\ \text { Total } & 63.160 & 17.480 & 3.000 & 83.640 & 100,0\end{array}$

(*) Piauí (1.650), Pernambuco (750), Alagoas (330), Sergipe (120), Paraíba (90) e Rio Grande do Norte (60).

Fonte: Banco do Nordeste do Brasil S. A., 1958, págs. 79-80.

Desse quadro ressalta a concentração do artesanato no Ceará e na Bahia (com mais de 96 por cento do total) e nuns poucos ramos de atividade: cestos e chapéus de palha, e ainda bordados, naquele primeiro Estado, charutos, redes e trançados no segundo. Algumas características gerais da atividade artesanal merecem destaque. Trata-se de ocupação, quase que exclusiva na maioria dos ramos, de mulheres e crianças da zona rural, que a alternam com os afazeres domésticos. Suplementam assim o orçamento da casa, com renda, mormente nos ramos de maior volume de emprego, extremamente baixa. "No Ceará, por exemplo", - escrevem os autores daquele estudo - "nos principais ramos do artesanato é necessário o trabalho de seis pessoas para a obtenção de renda equivalente ao salário mínimo do interior do Estado" (p.19). Sobre a fabricação manual de fósforos de segurança em Juazeiro, "atividade de baixo rendimento: para acrescentarmos mais um exemplo frizante, elucidam dizendo que as pessoas

entender como atividades artes anais aquelas em que as feições características do produto final dependem em grande parte da habilidade do trabalhador. $\mathrm{O}$ trabalho pode ser inteiramente manual ou contar com a ajuda de certos instrumentos" (p.8). A publicação não nos dá a data em que a pesquisa foi realizada. a ela "se dedicam apenas por não terem outra causa que fazer (p.45)". É desnecessário mencionar que a sobrevivência (e às vezes reaparecimento) do artesanato é indício claro da prevalência de desemprego e subemprego rural e urbano.

A produção, assinalemos ainda, faz-se em ramos importantes segundo o sistema da indústria a domicílio, o putting out da indústria têxtil na Inglaterra do século XVI ${ }^{36}$. É o que se dá com os bordados no Ceará:

As firmas principais têm agentes e as demais têm intermediários nos diversos municípios para a distribuição do tecido já desenhado e da linha às bordadeiras, para recolhimento do trabalho pronto e a realização de pagamentos (p.30).

A tendência para eliminação de muitos ramos pelo produto industrial está sobejamente ilustrada por aquela pesquisa.

A produção de renda [no Ceará] parece já ter ocupado grande número de pessoas (...) Encontra-se, porém, em franca decadência, tendendo ao desaparecimento. A causa do declínio dessa atividade é o lançamento de rendas produzidas à máquina e provenientes do Sul do país. Hoje o número de rendeiras (...) é relativamente pequeno (p.28).

O censo de 1950, poucos anos antes, ainda acusava 3.363 rendeiras naquele Estado ${ }^{37}$

Por que se conservam ainda as atividades artesanais e chegam algumas a experimentar certo desenvolvimento? Sem dúvida, a baixíssima renda do artesão e a forma de organização dessa produção, o putting out, são relevantes para a explicação dessa sobrevivência. São fatos interligados. O controle da produção por firmas comerciais amplia o mercado e, ao

\footnotetext{
${ }^{36}$ Sobre o putting out ver, por exemplo, o artigo de GAY, 1954.

${ }^{37}$ Entre outros, a pesquisa aponta o desaparecimento da ourivesaria em Rio das Contas e da tecelagem manual em Xique-Xique, assinalando nesse último caso que isso se deu "devido à entrada de produtos de fábrica favorecidos pela melhoria das condições de acessibilidade da área". Banco do Nordeste, 1958, págs. 65-66 e 72.
} 
mesmo tempo, concentra em suas mãos grande parte do lucro auferido ${ }^{38}$, sendo fundamental a natureza do mercado desses produtos artesanais, mercado esse que a maior parte das vezes transcende a região produtora e vai para outros Estados. Esse mercado é constituído de consumidores rurais e de pequenas vilas e cidades, de baixa capacidade aquisitiva, espalhados por todo o país. O chapéu de palha feito em grande quantidade no Ceará, "se destina às pessoas de renda mais baixa e residentes no interior" (p.26); o bordado daquele Estado raramente é de acabamento delicado, o seu baixo preço "assegurando-lhe amplo mercado entre as camadas de menores rendas e gosto menos apurado" (p.29); o uso das redes tecidas a mão "está disseminado" entre as mesmas camadas (p.33); as jóias de Juazeiro "são consideradas tipo 'combate', sendo vendidas às classes de renda mais baixa" (p.37). Outras vezes, numericamente menos importantes, como o caso da louça de barro, tanto no Ceará como na Bahia, a demanda é local e a precariedade dos transportes serve para protegê-la da concorrência do produto industrializado (veja-se a título de ilustração, na nota 20, a referência à tecelagem manual de Xique-Xique). O caráter marginal do mercado, mesmo nesses casos entretanto, tem o seu papel. Assinalam os autores: a concorrência do antigo de alumínio à louça de barro, verifica-se apenas nas camadas de nível de renda mais elevado (p.58).

Mercado amplo, formado por consumidores na verdade marginais, organizado por firmas concentrando os parcos rendimentos desse comércio, e, finalmente, renda baixíssima do produtor (seu caráter suplementar, pela qual mulheres e crianças ampliam o orçamento doméstico), são as condições da sobrevivência do artesanato. Sobrevivência precária, solapada,

\footnotetext{
${ }^{38}$ A. observações dos autores da pesquisa sobre a comercialização de bordados são pertinentes: O intermediário "tem como renda a diferença de preço que puder conseguir entre a bordadeira e a firma revendedora, o que toma provável a ocorrência de desvantagens para quem faz o bordado (...). O atendimento do gosto dos consumidores é tarefa dos revendedores, que escolhem os desenhos e a linha para os bordados. Nas condições atuais, trata-se de uma vantagem, pois as bordadeiras, residentes no interior e em grande parte na zona rural, não estariam em condições de determinar o tipo de bordado adequado a um mercado de âmbito nacional" (p.30). Resulta também, é preciso acrescentar, em dependência do produtor em relação ao comerciante. É o caso clássico do putting
} out. num ramo depois do outro, pela melhoria dos transportes, pela mais completa integração dos consumidores marginais à economia mercantil (elevação de renda monetária, transformação dos gostos) e pela penetração final do artigo industrializado. É um capítulo da constituição do mercado interno nacional.

Antônio Candido, com base em pesquisa realizada entre parceiros de um bairro rural de Bofete, no Estado de São Paulo ${ }^{39}$, caracteriza admiravelmente esse processo. Citemo-lo:

A marcha da urbanização em São Paulo está ligada ao processo industrial e conseqüente abertura de mercados; daí a penetração, em áreas rurais, de bens de consumo até então menos conhecidos ou, na maioria, desconhecidos. Surgem assim, para o caipira, necessidades novas, que contribuem para criar ou intensificar vínculos com a vida das cidades, destruindo a sua autonomia e ligando-o estreitamente ao ritmo da economia geral, isto é, da região, do Estado e do país, em contraste com a economia particular, centralizada pela vida do bairro e baseada na subsistência (p.129).

A quebra da auto-suficiência e a incorporação ao mercado alteram toda a vida caipira. Com a criação de novas necessidades, introduz-se profunda alteração no seu ritmo de trabalho: intensifica-se o labor agrícola regular, na qual ele agora se concentra, atrofiam-se as formas de solidariedade vicinal; modificam-se suas técnicas, usos e crenças ${ }^{40}$.

Queremos nesta altura sublinhar duas facetas do processo social de constituição do mercado: o aspecto psíquico das novas necessidades criadas e a diminuição da indústria doméstica.

Sobre a multiplicação de necessidades, afirma o autor que "envolve uma dimensão psíquica que a enraíza no terreno dos hábitos”, e constata:

(...) a importância do prestígio associado às práticas e usos de caráter urbano; a tal ponto que a pessoa se sente diminuída quando é

\footnotetext{
${ }^{39}$ Antônio CANDIDO, 1964. O trabalho de campo foi realizado entre 1947 e 1954.

${ }^{40}$ Toda a $3^{\text {a }}$ parte do livro. "Análise da mudança” (CANDIDO, 1964, págs. 134-171), é pertinente ao nosso problema.
} 
obrigada a manter os que se vão tornando, comparativamente, desprezados (p.143).

Pôde-se mesmo verificar o desaparecimento da indústria doméstica, tal a sua rapidez, durante os anos em que foi colhido o material da pesquisa. Escreve Antônio Candido:

Se considerarmos, por exemplo, o equipamento caseiro, não veremos mais as gamelas de raiz de figueira, as vasilhas de porunga, os potes de barro, as colheres de pau, feitas in loco. A folha-de-flandres, o ferro, a ágata, o alumínio e a louça começavam a lhes fazer concorrência, até as expulsarem de todo. Até os chapéus e as peneiras de palha, tão fáceis de fabricar, são agora comprados (p.141, grifos nossos).

Revela-se nesse trecho que se a manufatura doméstica do caipira, imerso em sua auto-suficiência econômica é, em parte, substituída pelo artigo fabril, também o é, em parte, pelo produto artesanal, organizado em escala ampla (indústria a domicílio). O chapéu de palha, antes feito pelo caipira, passa a ser comprado. Ele se origina do artesanato nordestino, organizado pelo comerciante-capitalista. Esclarece-se melhor o sentido da freqüente constatação da pesquisa do Banco do Nordeste sobre o artesanato: o mercado é nacional e constituído por pessoas de renda mais baixa, espalhadas pelas zonas rurais, vilas e pequenas cidades do país. O consumidor é marginal, recém-saído da economia natural, em processo de integração no mercado nacional. $\mathrm{O}$ produto artesanal que compra é em breve substituído pelo fabril. $\mathrm{O}$ artesanato sobrevive enquanto as necessidades dessa população ainda não se alteraram e as suas disponibilidades monetárias (na medida em que continua, em elevado grau, auto-suficiente) são exíguas.

A constituição da economia nacional envolve processo econômico e psicossocial de destruição do artesanato. Procuremos aquilatar seus aspectos e dimensões.

O uso de um artifício no tratamento dos dados dos censos demográfico e econômico nos permitiu chegar a estimativas, para as várias unidades da federação ${ }^{41}$, dos efetivos de artesãos e trabalhadores em domicílio. De fato, a categoria "indústria de transformação" do censo demográfico inclui todos, da população de 10 anos ou mais, que têm ocupação nesse ramo de atividade. No censo econômico (industrial), por seu turno, estão compreendidas apenas as pessoas que exercem atividade em estabelecimentos, excluindo-se, portanto, os trabalhadores de indústrias caseiras $^{42} \mathrm{e}$ os artífices (ambos incluídos no demo gráfico). Lembremo-nos, além disso, que numerosos artesãos (sobretudo mulheres e crianças) exercem essa ocupação como atividade suplementar, alternando-a com seus afazeres domésticos e escolares.

Daí o procedimento de que lançamos mão para estimar o número de artesãos e trabalhadores em domicílio: do total, para cada sexo, com ocupação em "indústria de transformação" (censo demográfico), seja como atividade principal seja como suplementar, deduzimos o pessoal ocupado nos estabelecimentos industriais (censo industrial ${ }^{43}$. Os resultados dessa

${ }^{41}$ Como já fizemos anteriormente, restringimo-nos às regiões Nordeste, Leste e Sul (ver nota 12 do capítulo II, supra).

${ }_{42} \mathrm{O}$ censo os caracteriza acertadamente como "os que executam em sua residência, mediante remuneração por tarefa, trabalhos parciais ou de acabamento com materiais fornecidos pelos estabelecimentos".

${ }^{43}$ As nossas estimativas de "artesãos e trabalhadores em domicílio", não coincidem portanto com as do artesanato conceituado segundo o caráter do trabalho (aquele em que o produto final depende em alto grau da habilidade do trabalhador), obtido pela pesquisa do Banco do Nordeste. As nossas devem ser maiores, incluindo quase todo o artesanato naquele sentido (não todo, porque parte dessa atividade se dá dentro de estabelecimento), mais os trabalhadores em domicílio e de pequenas oficinas, cujo trabalho não tem caráter artesanal. Comparando os nossos resultados para mulheres em 1950 (lembremo-nos que, segundo a pesquisa do Banco do Nordeste, 90 por cento dos efetivos totais em artesanato são constituídos por mulheres e crianças), com os daquele levantamento, vemos serem os nossos sempre maiores, mas guardando com eles certa proporção. A única exceção é o caso do Ceará: 63.000 naquela estimativa, cerca de 22.000 na nossa. É possível que tenha havido algum incremento na indústria em domicílio, entre 1950 e a data do levantamento (1956 ou 1957). Muitos dos que estão no artesanato naquele Estado, devem porém ou ter menos de 10 anos ou não ter declarado no censo de 1950 atividade remunerada, nem ao menos em caráter suplementar (ver a nota 14 do capítulo II, supra). Sendo por este último motivo o resultado do censo industrial, a partir dos estabelecimentos, mais completo que o do demográfico, obtém-se, às vezes, para os Estados com pequeno artesanato, como estimativa de "artesãos e trabalhadores em domicílio", um número negativo. Colocou-se nesse caso, no quadro XIII, zero. 
operação, para cada sexo, para 1940 e 1950, assim como a variação nesses dados durante aquele decênio, constam do quadro XIII.

\section{Quadro XIII}

Pessoal ocupado em estabelecimentos industriais (censo econômico) $e$ arte sãos e trabalhadores em domicílios (a), por unidade da federação e por sexo, 1940 e 1950

\begin{tabular}{|c|c|c|c|c|c|}
\hline \multirow{3}{*}{ Unidade da federação } & \multicolumn{4}{|c|}{ Homens } & \\
\hline & \multicolumn{2}{|c|}{$\begin{array}{l}\text { Pessoal ocupado } \\
\text { (censo econômico) }\end{array}$} & \multicolumn{3}{|c|}{$\begin{array}{c}\text { Artesãos e trabalhadores em } \\
\text { domicílio }(a)\end{array}$} \\
\hline & 1940 & 1950 & 1940 & 1950 & $\begin{array}{c}\text { Variação } 1940 \\
1950\end{array}$ \\
\hline \multicolumn{6}{|l|}{ Estados atrasados (b) } \\
\hline Maranhão & 3.418 & 7.696 & 11.327 & 6.810 & -4.517 \\
\hline Piauí & 1.028 & 2.239 & 8.557 & 8.068 & -489 \\
\hline Paraíba & 10.315 & 23.565 & 7.252 & 4.313 & -2.939 \\
\hline Ceará & 6.078 & 18.246 & 15.881 & 15.369 & -512 \\
\hline Alagoas & 10.120 & 17.101 & 9.144 & 7.948 & -1.196 \\
\hline Rio Grande do Norte & 3.243 & 13.331 & 5.479 & $0(\mathrm{c})$ & -5.479 \\
\hline Sergipe & 9.088 & 11.108 & 5.622 & 5.247 & -375 \\
\hline Bahia & 16.761 & 34.102 & 47.231 & 71.074 & +23.843 \\
\hline Pernambuco & 48.068 & 71.285 & 22.136 & 29.505 & +7.369 \\
\hline Espírito Santo & 3.594 & 8.826 & 6.736 & 6.372 & -364 \\
\hline Minas Gerais & 56.029 & 108.424 & 63.975 & 86.567 & +22.592 \\
\hline \multicolumn{6}{|l|}{$\begin{array}{l}\text { Estados médiose } \\
\text { adiantados }(b)\end{array}$} \\
\hline Rio de Janeiro & 38.899 & 75.785 & 39.022 & 62.668 & +23.646 \\
\hline Santa Catarina & 16.387 & 44.246 & 18.872 & 11.343 & -6.529 \\
\hline Paraná & 18.945 & 43.355 & 15.794 & 30.041 & +14.247 \\
\hline Rio Grande do Sul & 55.503 & 103.861 & 41.074 & 41.947 & +873 \\
\hline São Paulo & 214.080 & 418.207 & 133.968 & 220.005 & +86.037 \\
\hline Distrito Federal & 87.784 & 161.031 & 49.149 & 51.383 & +2.234 \\
\hline
\end{tabular}

$$
\operatorname{Brasil}(d) \quad 614.6001 .186 .274530 .552696 .073+165.521
$$

Examinemos inicialmente os dados referentes às mulheres, que constituem estimativas mais próximas do artesanato propriamente dito. Em todos os Estados atrasados (aqueles com produto per capita, em 1947, inferior à média nacional: os nordestinos mais o Espírito Santo e Minas Gerais), com a única exceção de Pernambuco, ocorre diminuição entre 1940 e 1950, em números absolutos, das artesãs e trabalhadoras em domicílio. Em alguns Estados as quedas são impressionantes: de quase 9.000 para menos de 1.000, no Maranhão, de mais de 13.000 para menos de 2.000, no Piauí. No total do Brasil, esses trabalhadores diminuem no decênio, de quase 60.000 (de 132.000 a 73.000). Nas unidades da federação com produto per capita superior à média, os do Sul e mais o Rio de Janeiro e o então Distrito Federal, essas trabalhadoras em geral quase não diminuíram ou chegaram mesmo a aumentar. Provavelmente trata-se agora menos de artesãs do que pessoal empregado em pequenas oficinas (inclusive membros da família), que podem até crescer com a industrialização.

\begin{tabular}{cccccc}
\multicolumn{7}{c}{ Mulheres } \\
Pnidade da federação & $\begin{array}{c}\text { Pessoal ocupado } \\
(\text { censo economico })\end{array}$ & Artesãs e trabalhadoras em domicílio (a) \\
& 1940 & 1950 & 1940 & 1950 & Variação 1940-1950 \\
Estados atrasados $(b)$ & & & & & \\
Maranhão & 2.013 & 2.709 & 8.794 & 723 & -8.071 \\
Piauí & 232 & 204 & 13.086 & 1.655 & -11.431 \\
Paraíba & 3.855 & 5.610 & 2.610 & 787 & -1.823 \\
Ceará & 894 & 3.409 & 33.038 & 21.897 & -12.141 \\
Alagoas & 3.909 & 7.691 & 3.513 & 1.059 & -2.454 \\
Rio Grande do Norte & 348 & 532 & 4.597 & 1.367 & -3.230 \\
Sergipe & 3.496 & 5.500 & 5.401 & 2.044 & -3.357 \\
Bahia & 8.621 & 8.188 & 32.169 & 15.431 & -17.738 \\
Pernambuco & 14.034 & 19.650 & 4.849 & 5.286 & +437 \\
Espírito Santo & 349 & 869 & 124 & 99 & -25 \\
Minas Gerais & 14.674 & 25.445 & 12.294 & 5.836 & -6.458 \\
Estados médios e adiantados $(b)$ & & & & & \\
Rio de Janeiro & 11.244 & 16.834 & 162 & 3.020 & +2.858 \\
Santa Catarina & 4.506 & 9.168 & 2.536 & $0(\mathrm{c})$ & -2.536
\end{tabular}




$\begin{array}{cccccc}\text { Paraná } & 2.422 & 4.888 & 0(\mathrm{c}) & 491 & +494 \\ \text { Rio Grande do Sul } & 12.657 & 22.002 & 0(\mathrm{c}) & 0(\mathrm{c}) & 0 \\ \text { São Paulo } & 89.305 & 158.559 & 0(\mathrm{c}) & 12.733 & +12.733 \\ \text { Distrito Federal } & 25.659 & 42.292 & 0(\mathrm{c}) & 133 & +133 \\ \text { Brasil (d) } & 200.441 & 336.570 & 0(\mathrm{c}) & 73.150 & -59.340\end{array}$

(a) População de 10 anos ou mais com atividade principal ou suplementar em Indústria de transformação (censo demográfico) menos pessoal ocupado em estabelecimentos industriais (censo econômico).

(b) Segundo o produto per capita em 1947 era maior ou menor que a média nacional. Dentro de cada classe, as unidades da federação estão arranjadas em ordem crescente do produto per capita.

(c) Nos casos em que o cálculo de artesãos e trabalhadores em domicílio resultou negativo (ver nota 26 ao texto), colocou-se zero.

(d) Inclusive os demais Estados e territórios.

Fonte: Dados dos censos.

Contingentes desse último tipo devem ser mais freqüentes entre os elementos masculinos da categoria artesãos e trabalhadores em domicílio: as quedas de efetivos masculinos entre 1940 e 1950 nos Estados atrasados são bem menores e em três deles, Bahia, Pernambuco e Minas Gerais, há aumento, ao invés de diminuição. Entre as unidades da federação da parte do Sul do país, apenas em Santa Catarina diminuem os homens na categoria em consideração.

Surge com maior clareza o que está ocorrendo no país com os artesãos e trabalhadores em domicílio no quadro XIV. Nele figura, para cada unidade da federação e cada sexo, o número de indivíduos naquelas categorias para cada pessoa em estabelecimento industrial, em 1940 e 1950, assim como a variação nesse índice durante aquela década. Nota-se já em 1940, mais claramente para as mulheres, mas também para os homens, como entre os Estados atrasados são os mais distantes dos principais mercados urbanos (centros de irradiação de artigos industriais fabricados aí e no Sul), isto é, distantes de Recife, do Rio de Janeiro e da parte urbanizada de Minas Gerais, os que apresentam os índices mais altos. Assim, para cada mulher ocupada em estabelecimento industrial, havia em 194056 artesãs e trabalhadoras em domicílio no Piauí, 37 no Ceará, 13 no Rio Grande do Norte, cerca de 4 no Maranhão e na Bahia (parte considerável desse Estado é de difícil acesso), 1,5 em Sergipe. Pernambuco, Paraíba, Alagoas (próximos de Recife), Espírito Santo e Minas Gerais (perto do Rio de Janeiro e de cidades mineiras) apresentavam menos de uma artesã para cada pessoa empregada em estabelecimento industrial. Ainda mais, embora os índices em todos os Estados atrasados diminuam durante o decênio, o decréscimo é bem mais pronunciado para os que revelavam em 1940 maiores quantidades relativas de artesãs e trabalhadoras em domicílio. Para os Estados médios e adiantados o fato fundamental é, em todos os casos, o nível quase insignificante dos números relativos de artesãs e trabalhadoras em domicílio. Menos pronunciadamente embora, as mesmas coisas podem ser observadas para os homens.

Pelo exame desse quadro, percebe-se a rapidez do desaparecimento do artesanato em todas as áreas do Brasil, o qual se dá em etapas.

A diminuição gradativa das manufaturas domésticas para auto consumo é processo que, com altos e baixos, nos acompanha nos últimos cem anos. Referimo-nos acima ${ }^{44}$ à dissolução do "complexo rural" por força da expansão cafeeira. Com a marcha do café para o Oeste, nas áreas mais afastadas das comunicações e transportes, reconstituía-se na sua esteira a economia auto-suficiente do caipira ${ }^{45}$. Agora, no período mais recente, entretanto, essa indústria doméstica, que faz parte da economia natural, passa (ou volta) a desintegrar-se por todo o país, pela entrada do produto manufaturado na vida cabocla e pela conseqüente integração do rurícola em certo grau nas atividades agrícolas de abastecimento urbano. O produto manufaturado que compra é, porém, muitas vezes artesanal. $\mathrm{O}$ artesanato readquiriu assim condições de sobrevivência e, o de alguns ramos, passou a ser fabricado em escala, com certa expressão, nalgumas áreas. Nelas a produção é controlada por comerciantes-capitalistas, apoiada, de um lado, em produtores de baixas rendas, parte de uma população pobre e subempregada, e, de outro, dependendo de um consumidor marginal, em

${ }^{44}$ P.12.

${ }^{45}$ Sobre a área que estudou, escreve Antônio CANDIDO: "Sobre as ruínas do latifúndio produtivo, na ausência de liderança econômica, a cultura tradicional se refez como cicatriz, restabelecendo-se o ritmo interrompido da vida caipira. A fazenda se tornou um quase bairro no sentido social da palavra". Aquela se constitui de "glebas dadas em parceria", sob a vigilância distante do proprietário. A produção volta-se na maior parte para o autoconsumo. CANDIDO. 1964, p.88 
transição da economia natural para a mercantil. Nessa passagem, o habitante rural primeiro deixa de produzir ele mesmo as manufaturas, para autoconsumo, e passa a comprar os toscos produtos quase equivalentes, fabricados em escala considerável em alguns centros de artesanato do país. Na medida, porém, em que sua integração no mercado é mais completa, deixa de consumir o artigo artesanal para comprar o industrial ${ }^{46}$.

\section{Quadro XIV}

Número de artesãos e trabalhadores em domicílio (a) para cada pessoa em estabelecimento industrial (censo econômico), em 1940 e 1950

Unidades da Federação Número de artesãos e trabalhadores em domicílio (a) para cada pessoa em estabelecimento industrial

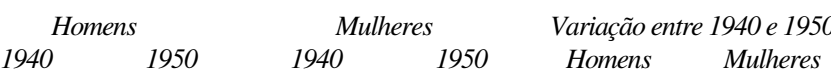

Estados atrasados

$\begin{array}{ccccccc}\text { Maranhão } & 3,3 & 0,9 & 4,4 & 0,3 & -2,4 & -4,1 \\ \text { Piaú́ } & 8,3 & 3,6 & (56,4) \mathrm{c} & (8,1) \mathrm{c} & -4,7 & (-48,3) \mathrm{c} \\ \text { Paraíba } & 0,7 & 0,2 & 0,7 & 0,1 & -0,5 & -0,6 \\ \text { Ceará } & 2,6 & 0,8 & 37,0 & 6,4 & -1,8 & -30,6 \\ \text { Alagoas } & 0,9 & 0,5 & 0,9 & 0,1 & -0,4 & -0,8 \\ \text { Grande do Norte } & 1,7 & 0 & (13,2) \mathrm{c} & 2,6 & -1,7 & (-10,6) \mathrm{c} \\ \text { Sergipe } & 0,6 & 0,5 & 1,5 & 0,4 & -0,1 & -1,1 \\ \text { Bahia } & 2,8 & 2,1 & 3,7 & 1,9 & -0,7 & -1,8 \\ \text { Pernambuco } & 0,5 & 0,4 & 0,3 & 0,3 & -0,1 & 0 \\ \text { Espírito Santo } & 1,9 & 0,7 & (0,4) \mathrm{c} & 0,1 & -1,2 & (-0,3) \mathrm{c}\end{array}$

${ }^{46}$ Todo esse processo está a merecer pesquisa em profundidade. Trata-se de estudar a produção para atendimento da. população rural ou semi-rural, mal integrada no mercado e com padrões de consumo quase não afetados pela industrialização. Muitas vezes, essa produção fez-se artesanalmente, mas em escala local e não-organizada de modo capitalista. É o caso da louça de barro ou o dos utensílios caseiros, fabricados freqüentemente com resíduos industriais, tais como latas usadas para fazer lamparinas e formas de bolo. Outras vezes produz-se em fábrica produtos para esse mercado consumidor marginal. Parece ser o caso dos ferros a carvão, panelas de ferro, feitos em São Paulo ou Belo Horizonte, para a população do interior. Agradecemos ao Prof. Flávio MOTTA ter-nos advertido sobre os exemplos acima. No texto, tratamos apenas do fenômeno que nos pareceu mais importante. Ver, também, HARRIS, 1956, págs. 44-71.

$\begin{array}{ccccccc}\begin{array}{c}\text { Minas Gerais } \\ \text { Estados médiose } \\ \text { adiantados }(b)\end{array} & 1,1 & 0,8 & 0,8 & 0,2 & -0,3 & -0,6 \\ \text { Rio de Janeiro } & 1,0 & 0,8 & 0 & 0,2 & -0,2 & +0,2 \\ \text { Santa Catarina } & 1,2 & 0,4 & 0,3 & 0 & -0,8 & -0,3 \\ \quad \text { Paraná } & 0,8 & 0,7 & 0 & 0,1 & -0,1 & +0,1 \\ \text { Rio Grande do Sul } & 0,7 & 0,4 & 0 & 0 & -0,3 & 0 \\ \quad \text { São Paulo } & 0,6 & 0,5 & 0 & 0,1 & -0,1 & +0,1 \\ \text { Distrito Federal } & 0,6 & 0,3 & 0 & 0 & -0,3 & 0 \\ \text { Brasil }(d) & 0,9 & 0,6 & 0,7 & 0,2 & -0,3 & +0,5\end{array}$

(a) População de 10 anos ou mais com atividade principal ou suplementar em indústria de transformação (censo demográfico) menos pessoal ocupado em estabelecimentos industriais (censo econômico).

(b) Segundo o produto per capita em 1947, era maior ou menor que a média nacional. Dentro de cada classe, as unidades da federação estão arranjadas em ordem crescente do produto per capita.

(c) Índices calculados na base de menos de 500 pessoas ocupadas na Indústria.

(d) Inclusive os demais Estados e territórios.

Fonte: Dados do quadro XIII.

Nas várias fases do processo, é o que cabe agora destacar, a ampliação do mercado nacional, parte integrante do sistema industrial em constituição destrói oportunidades de trabalho no mundo rural e semi-rural, sem criar outras tantas na mesma proporção nas cidades, para onde aflui a população excedente. O crescimento "excessivo" dos centros urbanos das regiões menos desenvolvidas do Brasil adquire sentido dentro desse quadro.

As consequiências do sistema industrial emergente, entretanto, não se fazem sentir apenas na sua incidência sobre a agropecuária nas mais variadas regiões do país ou sobre a indústria doméstica, seja como enclave autônomo dentro do "complexo rural", seja como artesanato local ou organizado em ampla escala. Além disso, devido às mesmas causas, intensificam-se as migrações internas no país e altera-se a sua natureza.

\section{As migrações inter-regionais}

Nas últimas décadas as populações brasileiras passaram a movimentar-se. A industrialização provoca pronunciados desníveis sócioeconômicos no país. Ao mesmo tempo cria-se a rede de transportes e de comunicações, unificando em um mercado nacional as várias regiões 
brasileiras. São essas as condições básicas das migrações internas. Nas últimas três décadas elas se intensificam. A sua raiz está no próprio desenvolvimento econômico e no sistema industrial dele resultante. Analisemos as dimensões e a aceleração, as causas, as principais correntes e o significado do movimento migratório ${ }^{47}$.

O registro, pelos censos de 1940 e 1950, do Estado natal da população presente em cada unidade da federação naquelas datas, constitui a principal fonte de dados para se caracterizar as migrações recentes ocorridas no Brasil. Dão apenas os contornos dos fluxos migratórios permitindo-nos avaliar os seus saldos na data de cada censo ${ }^{48}$.

${ }^{47} \mathrm{O}$ conhecimento das migrações internas no Brasil é precário. Baseia-se, em última instância, de um lado, em estatística em São Paulo, da Hospedaria de Imigrantes e do Departamento de Imigração e Colonização, e do desembarque de passageiros de terceira classe no Porto de Santos, assim como para todos Estados de dados dos censos de 1940 e 1950, que registraram o Estado de naturalidade da população presente em cada unidade da federação; do outro lado, num pequeno numero de pesquisas que dizem respeito, principalmente, a migrações para determinadas cidades. Na análise do texto, nos valemos dos seguintes trabalhos: 1) entre os do primeiro tipo: J. F. CAMARGO, 1957, págs. 91-110; Accioly BORGES, 1955; COSTA PINTO, 1952 (trabalho que inclui também informações preciosas baseadas em pesquisa de campo sobre as correntes migratórias da Bahia para o Sul); e NOGUEIRA, 1964; 2) entre as pesquisas do segundo tipo: Unzer de ALMEIDA e Teixeira MENDES SOBRINHO, 1951; Lacerda de MELO e outros, 1961; COMISSÃO NACIONAL DE POLÍTICA AGRÁRIA, 1955; e B. HUTCHINSON, 1963. As súmulas gerais sobre o fenômeno feitas por SMITH, LAMBERT e CHARDON foram igualmente úteis. Ver SMITH, 1963, págs. 144-198; LAMBERT, 1959, págs. 71-86 e CHARDON, 1966, págs. 155-178. No momento, interessa-nos, como está dito, caracterizar a natureza das migrações internas, sua intensificação, causas, principais direções e suas consequiências. Há outros estudos versando sobre a integração do migrante na sociedade urbano-industrial, cujos dados usaremos num ponto, e noutro deste trabalho.

${ }^{48}$ Calculado como a perda ou ganho de população entre cada unidade da federação e todas as demais (nascidos fora do Estado e nele residentes menos os nele nascidos, mas residentes nos demais) ou, por diferença, o saldo que se verifica no período intercensitário. Adverte-nos Accioly BORGES: obtemos assim "o saldo líquido, o resultado geral das correntes, emigratória e imigratória, em cada unidade da federação. Esse saldo (...) não representa nem os ganhos, nem as perdas reais da unidade considerada, primeiramente porque os filhos dos migrantes, nascidos no Estado para o qual emigraram, já possuem naturalidade diferente da dos pais; em segundo lugar, porque o resultado censitário não dá conta dos óbitos ocorridos no período". Accioly BORGES, 1955, p.10. Esse último fato resulta em grande subestimativa do saldo realmente verificado. T. Lynn SMITH, em cálculo cuidadoso, tomando em consideração os óbitos, estima em 392.829 a migração de brasileiros de
T. Lynn Smith ${ }^{49}$, baseando-se em tais dados, organizou para 1950 quadros onde assinala as trocas de população entre as unidades da federação do país. Tal saldo refere-se a todo período anterior ao censo. Como entretanto as migrações inter-regionais surgem no Brasil, com intensidade significativa, ao redor de 1930, pode-se dizer que esses dados refletem principalmente o fluxo migratório dos últimos decênios. Anotando-se todos os casos em que a perda ou ganho de população foi superior a quarenta mil pessoas, pudemos observar com clareza os movimentos principais. $\mathrm{O}$ mais volumoso origina-se de Minas Gerais, da Bahia e dos Estados nordestinos, para São Paulo, Rio de Janeiro (inclusive a então Capital Federal) e Paraná. Outro dirige-se do leste para o oeste, principalmente de Minas, da Bahia e dos Estados nordestinos para Goiás. Outros fluxos menores constituem-se de populações em demanda do Maranhão, provindos do Piauí e do Ceará, e do Rio Grande do Sul, para Santa Catarina e Paraná.

Quadro XV

Sumário das mudanças populacionais do Brasil, 1950-1960

$\begin{array}{ccc}\text { Categoria } & \text { Aumento da população de } 1950 \text { a } 1960 \\ & N & \% \\ \text { População urbana (a) } & 9.088 .810 & 47,7 \\ 10 \text { cidades de 300 mil ou mais } & 5.308 .906 & \\ 15 \text { cidades de 100 a 300 mil } & 1.006 .748 & \\ 120 \text { cidades menores } & 2.673 .296 & \\ \text { População não-urbana } & & 19,1 \\ \text { 4 Estados “pioneiros" (b) } & 3.620 .878 & 20,7 \\ \text { 7 Estados do Leste e Sul (c) } & 3.921 .338 & 12,5 \\ \text { Demais Estados } & 2.391 .762 & \end{array}$

outros Estados para o então Distrito Federal, entre 1940 e 1950. Fazendo-se a diferença entre os saldos verificados naquelas datas, obtém-se apenas 249.459, quase 150.000 a menos (SMITH, 1963, págs. 147-149). É ocioso lembrar que, com dados sobre o Estado natal e o Estado de nascimento, não se apanham os movimentos de menor duração, nem, é. claro, os que se dão dentro dos limites do mesmo Estado.

${ }^{49}$ Ver no seu livro as tabelas XXVII, XXXI e XXXIII (SMITH, 1963, págs. 147, 183 e 187-193). 


\section{Brasil}

População total dos Estados do Leste e do Sul

População total de 3 Estados "pioneiros" (c)

População urbana no restante do país

População não-urbana no restante do país

$$
\text { Brasil }
$$

19.022 .788

12.540 .563

2.178 .792

1.911 .671

2.391 .762

19.022.788

100,0

66,0

11,4

10,1

12,5

100,0

(a) Definida como a população dos centros urbanos com vinte e cinco mil habitantes, ou mais. Os limites das classes de tamanho das cidades referem-se a 1960

(b) Paraná, Goiás, Mato Grosso e Maranhão.

(c) Todos os Estados dessas regiões menos o Paraná.

(d) Exceto O Paraná.

Fonte: CHARDON. 1966, p.173.

Não foram publicados os dados equivalentes a esses para 1960. O crescimento da população entre 1950 e 1960 permite-nos, porém, verificar a continuação daqueles fluxos migratórios e notar alguns novos aspectos dos movimentos populacionais. A população brasileira cresceu, no período, 19 milhões de habitantes. Chardon ${ }^{50}$ analisou quais as partes do país responsáveis pelas maiores proporções daquele aumento, assim como quais acusaram maior crescimento relativo. No quadro XV resume-se a sua análise, com duas maneiras diversas de classificar-se o incremento da população brasileira, por regiões e por grau de urbanização. Visto de qualquer dos dois modos assinalados no quadro, o crescimento da população nos anos recentes concentrou-se numa estreita área do território brasileiro: nas cidades e na parte não-urbana dos Estados do Leste e do Sul e dos "pioneiros", onde se está expandindo a fronteira agrícola ${ }^{51}$. Em outras palavras (pois a parte inferior do quadro representa apenas maneira diversa de se categorizar a mesma coisa), o crescimento principal deu-se nos Estados do Leste e do Sul e nos pioneiros, tanto nas suas populações urbanas como nas não-urbanas, assim como na urbana do restante do país. Essas partes são responsáveis por 88 por cento do aumento global ocorrido

\footnotetext{
${ }^{50}$ CHARDON, 1966, especialmente págs. 168-178.

${ }^{51}$ Note-se que entre os Estados "pioneiros" coloca-se o Paraná, pertencente também à Região Sul.
}

no decênio ${ }^{52}$. O restante do Brasil constitui-se da população não-urbana da Amazônia e do Nordeste (com a exclusão do Maranhão). Segundo expressa-se Chardon, o crescimento aí foi

(...) pouco mais de dois milhões de pessoas. Isso representa menos que a taxa normal de crescimento natural; a conclusão parece ser que essas áreas foram áreas de saldo emigratório (net emigration).

\section{E conclui:}

No geral, brasileiros entre 1950 e 1960 emigraram do Nordeste rural (especialmente do interior) para as cidades do litoral, para o Sul e Sudeste mais rico, e para a "franja pioneira" (p.175).

Três zonas pioneiras são identificadas pelo autor como sendo as principais. A mais importante abre-se em leque desde o nordeste do Paraná, incluindo o sul do Mato Grosso, até o sul de Goiás. Dois milhões de pessoas talvez moveram-se para essa área durante o decênio. É expansão ligada ainda, em boa medida, ao café. Outra situa-se no sudoeste do Paraná, e pequenas áreas de Santa Catarina e Rio Grande do Sul. A migração para ela envolveu população superior a meio milhão e deve-se à expansão de agricultura diversifica da e em pequena escala ${ }^{53}$. A terceira zona pioneira situa-se na região central do Maranhão e atraiu cerca de seiscentas mil pessoas. Três a três milhões e meio de indivíduos aumentaram a população dessas três áreas, constituindo assim o incremento populacional dos Estados denominados "pioneiros" no quadro XV.

Essa análise de Roland Chardon indica serem os fluxos migratórios do período recente essencialmente continuação dos vindos de décadas anteriores.

${ }^{52}$ Análise mais detida mostraria a CHARDON que as populações rurais de dois Estados do Leste e do Sul - Minas e o Rio Grande do Sul - apresentaram crescimento bem menor e foram também, provavelmente, áreas de emigração.

${ }^{53}$ Em Toledo, no sudoeste do Paraná, por exemplo, 86,4 por cento da população nasceu fora do município, a grande maioria no Rio Grande do Sul e em Santa Catarina. Trata-se de colonização organizada por companhia de terras; a pequena agricultura diversificada predomina. OBERG, 1957, págs. 19-22 e 35-36. 
Podemos agora formular melhor o caráter das migrações internas. São três as correntes principais:

1. A rural-urbana, em todo o país (como porém a maioria das cidades se situa no Leste e no Sul, esse fluxo significa também movimento para essas regiões);

2. A inter-regional do Nordeste para o Leste e para o Sul;

3. A para a "franja pioneira", no Paraná, Mato Grosso, Goiás e Maranhão.

Os movimentos inter-regionais de população estão se intensificando. Lembra-nos Lambert:

O Brasil nunca teve essa mobilidade: em período' bastante recente, em que a sua fecundidade era, entretanto, tão grande quanto a de hoje, teve de recorrer a imigrantes europeus para suprir os claros do Estado de São Paulo, pois era mais fácil deslocar o estrangeiro do que o homem do interior. Foi só depois da Primeira Guerra Mundial que a população do Brasil se pôs em movimento, movimento esse que, depois da Segunda Guerra, aumentou de tal maneira que chegou a causar inquietações ${ }^{54}$.

É possível comprovar essa intensificação, com dados censitários, para a década de 1940 a 1950. Calculamos, separadamente para 40 e 50, para cada Estado, taxas de emigração (a porcentagem dos naturais do Estado que residiam fora dele) e taxas de imigração (brasileiros nascidos fora do Estado nele presentes, em porcentagem de sua população) que figuram no quadro XVI. Registramos aí também a diferença entre as duas taxas, como indicador da qualidade do Estado como de emigração ou de imigração ${ }^{55}$.

\footnotetext{
${ }_{55}^{54}$ LAMBERT, 1959, p.75.

${ }^{55}$ Note-se a utilização, no cálculo das duas taxas, de populações-base diversas, a dos brasileiros natos no Estado, para a taxa de emigração, e a total do Estado (brasileiros, nascidos nele ou não, e estrangeiros), para a de imigração. Isso explica não se obter para o Brasil globalmente o mesmo valor. A taxa de imigração, lembre-se, é influenciada pelo número de pessoas nascidas no estrangeiro.
}

Quadro XVI

Taxas de emigração e de imigração por Estado, em 1940 e 1950

\begin{tabular}{|c|c|c|c|c|c|c|}
\hline \multirow{2}{*}{ Estado } & \multicolumn{2}{|c|}{ Taxa de emigração $\left(^{*}\right)(E)$} & \multicolumn{2}{|c|}{ Taxa de imigração $(* *)(I)$} & \multicolumn{2}{|c|}{ Diferença $(I-E)$} \\
\hline & 1940 & 1950 & 1940 & 1950 & 1940 & 1950 \\
\hline \multicolumn{7}{|l|}{ Estados de Imigração } \\
\hline Paraná & 6,2 & 4,9 & 17,5 & 31,1 & 11,3 & 26,5 \\
\hline Goiás & 5,1 & 3,8 & 18,8 & 23,2 & 13,7 & 19,4 \\
\hline Rio de Janeiro (***) & 5,9 & 4,9 & 14,6 & 18,2 & 8,7 & 13,3 \\
\hline São Paulo & 4,0 & 6,4 & 10,4 & 11,8 & 6,4 & 5,4 \\
\hline Acre & 15,0 & 13,7 & 28,7 & 25,6 & 13,7 & 11,9 \\
\hline Mato Grosso (***) & 4,6 & 7,8 & 16,5 & 19,3 & 11,9 & 11,5 \\
\hline Maranhão & 6,5 & 6,6 & 10,6 & 10,2 & 3,7 & 3,6 \\
\hline \multicolumn{7}{|l|}{ Estados Intermediários } \\
\hline Santa Catarina & 5,6 & 7,9 & 9,2 & 9,8 & 3,6 & 1,9 \\
\hline Pará $(* * * *)$ & 4,6 & 7,2 & 8,2 & 8,8 & 3,6 & 1,6 \\
\hline Amazonas $(* * * *)$ & 6,1 & 10,4 & 12,3 & 12,0 & 6,2 & 1,6 \\
\hline Rio Grande do Norte & 9,5 & 10,4 & 8,3 & 8,0 & $-1,2$ & $-2,4$ \\
\hline Pernambuco & 8,8 & 8,9 & 4,9 & 6,2 & $-3,9$ & $-2,7$ \\
\hline \multicolumn{7}{|l|}{ Estados de Emigração } \\
\hline Rio Grande do Sul & 4,0 & 4,8 & 1,3 & 1,1 & $-2,7$ & $-3,7$ \\
\hline Piaú & 13,2 & 13,1 & 8,2 & 8,3 & $-5,0$ & $-4,8$ \\
\hline Ceará & 9,3 & 9,4 & 4,3 & 4,1 & $-5,0$ & $-5,3$ \\
\hline Bahia & 8,2 & 8,4 & 2,7 & 3,0 & $-5,5$ & $-5,4$ \\
\hline Espírito Santo & 9,6 & 16,3 & 14,2 & 10,8 & 4,6 & $-5,5$ \\
\hline Paraíba & 10,8 & 13,3 & 7,4 & 5,9 & $-3,4$ & $-7,4$ \\
\hline Sergipe & 13,0 & 15,1 & 6,2 & 5,7 & $-6,8$ & $-9,4$ \\
\hline Alagoas & 13,1 & 16,8 & 6,3 & 6,1 & $-6,8$ & $-10,7$ \\
\hline Minas Gerais & 11,3 & 15,5 & 2,9 & 2,8 & $-8,4$ & $-12,7$ \\
\hline
\end{tabular}

(*) Naturais do Estado presentes em outras unidades da federação em porcentagem do total dos naturais do Estado.

(**) Brasileiros naturais de outras unidades da federação, no Estado especificado, em porcentagem da população total do Estado.

(***) Inclusive a cidade do Rio de Janeiro (o então Distrito Federal).

(****) Mato Grosso, Pará e Amazonas em 1950, inclusive, respectivamente, os territórios do Guaporé, Amapá e Rio Branco.

Fonte: Dados censitários.

A constatação básica a se fazer é o aumento no decênio da taxa de imigração para os Estados de imigração e o da taxa de emigração, para os 
de emigração. Entre os primeiros destacam-se o Paraná (a taxa de imigração aumenta de 17 para 31 por cento), Goiás (de 19 para 23 por cento) e Rio de Janeiro $^{56}$ (de 15 para 18 por cento).

A elevação da taxa de emigração nos Estados de emigração, bem mais numerosos, quase não apresenta exceções. A taxa aumenta no Espírito Santo de 10 a 16 por cento, em Minas de 11 a 15, de 13 a 17 em Alagoas, de 13 a 15 em Sergipe, e assim por diante. Todos os Estados do Nordeste, e Minas, Bahia e Rio Grande do Sul, são de emigração. Entre eles, somente Pernambuco, Piauí e Ceará mantêm aproximadamente a mesma taxa de evasão populacional.

Entre as causas das migrações internas, os autores em geral incluem forças de repulsão, tais como a alta concentração da propriedade da terra, os progressos técnicos na agricultura, os baixos salários aí prevalecentes, as secas nordestinas periódicas e o alto crescimento vegetativo da população rural, e forças de atração, coma são os salários mais altos das zonas rurais do Sul, as melhores oportunidades na fronteira econômica agrícola, e vantagens de toda ordem, na sua maior parte concentradas nas cidades (não só salariais, como também no tocante à legislação social, educação, etc. $)^{57}$.

Os movimentos inter-regionais, em particular os de uma zona rural para outra, são os que mais nos interessam no momento. Para esses, são relevantes as observações de Accioly Borges ${ }^{58}$ sobre os resultados do inquérito rural realizado pela Comissão Nacional de Política Agrária em colaboração com o Instituto Brasileiro de Geografia e Estatística, assinalando que, entre os motivos apontados para saída de trabalhadores rurais, predominou em esmagadora maioria, "salários baixos". Somente nos Estados nordestinas, acrescenta o autor, e entre os do Leste na Bahia,

\footnotetext{
${ }^{56}$ Incluímos o Estado do Rio e a cidade do Rio de Janeiro numa única unidade e excluímos as migrações de um para outro, que no final de contas têm primordialmente o caráter de êxodo ruralurbano.

${ }^{57}$ Veja-se, entre outros, o tratamento do assunto por Oracy NOGUEIRA, 1964, especialmente págs. 22-24, T. Lynn SMITH, 1963, págs. 150-155, e J. F. CAMARGO, 1957, págs. 35-90.

${ }^{58}$ Accioly BORGES, 1955 , págs. 25 e 26.
}

"outras razões" (provavelmente seca, má qualidade das terras, etc.) foram indicadas em escala apreciável. Ainda segundo o mesmo autor:

Em 199 dos 304 municípios onde ocorreu entrada apreciável de trabalhadores o pagamento mais freqüente era só em dinheiro, comprovando-se, destarte, que o salariado puro - tipo de remuneração por excelência da economia capitalista - constitui, quando outras condições favoráveis também existem, um motivo especial de atração para as massas emigrantes.

A essas considerações, devemos acrescentar outras, bem esclarecedoras, encontradas em um estudo do antropólogo Marvin Harris, sobre o município de Brumado, na Bahia, um dos que apresentam maior evasão para São Paulo. Diz ele:

Falta de terra na quinta geração é uma certeza matemática entre esses lavradores que vivem na margem do rio. A fome de terra, por isso mesmo, é um traço dominante da vida aqui em Brumado. No mínimo metade da população do Município não possui terra bastante para garantir seu sustento durante todo o ano; e trabalhar em terra alheia é a principal solução para o problema, cuja gravidade está constantemente aumentando (...).

E mais adiante:

Um número considerável de homens e mulheres de Brumado estão presentemente, ou já estiveram, em São Paulo. Todos são trabalhadores agrícolas. (...) Creio que um interessante e pouco reconhecido aspecto dessas emigrações (...) ficou aqui esclarecido para mim. As razões da mobilidade são geralmente concebidas como uma atração de fora, sob a forma de trabalho remunerado com salário. Em regra eles não tomam consciência das razões que dentro os leva a se deslocarem - a tremenda pressão representada pela raridade ou ausência de terras, que eles sofrem em todas as zonas do Estado onde se encontra esse tipo de agricultura. O trabalhador agrícola atraído para São Paulo não é arrancado, de suas terras - pois ele não as possui ${ }^{59}$.

\footnotetext{
${ }^{59}$ Apud COSTA PINTO, 1952, capítulo III: "Migrações intra-rurais: migrações para São Paulo".
} 
Como parte da estrutura agrária altamente concentrada, nas áreas rurais "velhas" de baixa produtividade, o trabalhador não chega a perceber as forças que daí o repelem, surgindo pelo contrário no nível da sua consciência as de atração, no anseio por exemplo de trocar a meiação pelo salário, com a migração para São Paulo.

É necessário, porém, aprofundar mais a nossa compreensão desses movimentos de população, particularmente da sua intensidade crescente e das direções que agora toma. Nesse sentido é preciso ver serem suas precondições o desenvolvimento agrícola e industrial do Centro-sul, a necessidade de mão-de-obra nessa região ${ }^{60}$, as estradas e meios de transporte criados como parte da integração do sistema urbano-industrial em escala inter-regional, a intensificação das comunicações também por ele propiciada, etc.

Importantes entre as causas dos fluxos migratórios são as secas do Nordeste. Vejamo-las nesse contexto das transformações econômicas e sociais no Brasil.

Os movimentos demográficos por elas provocados condicionam-se hoje profundamente pelo sistema industrial em formação no país. De início, a densidade da população árida era baixa, e os flagelados afluíam do Sertão para o litoral. Provavelmente da perturbação periódica do equilíbrio homem-meio resultavam apenas movimentos relativamente curtos, circunscritos à região.

Com a grande seca de 1877-79 chega-se ao fim dessa fase. O fenômeno foi especialmente cruel e prolongado. Mais da metade da população do Ceará, segundo Rodolpho Theophilo, o seu historiador, pereceu por causas, direta ou indiretamente, a ela relacionadas. Alguns retirantes dirigiram-se à Amazônia. As migrações na quase totalidade restringiram-se ainda à região. Pela primeira vez, porém, a Nação tomou

\footnotetext{
${ }^{60}$ Nota-se, pelo quadro XVI, ser São Paulo não apenas receptor de massas migrantes, como fonte de emigrações para a fronteira econômica, que se distancia além de suas fronteiras, no Paraná, Mato Grosso e Goiás. Os mineiros e nordestinos que vêm para nossa lavoura vêm em parte substituir os paulistas que daqui emigraram
}

consciência do flagelo. A seca nordestina passou a ser problema nacional. As primeiras medidas do Governo Central foram tomadas. Daí em diante, flagelados começam a sair da região, atraídos pela borracha da Amazônia. Com a débâcle dessa economia, nos anos 20, diminuiu esse movimento ${ }^{61}$.

Ao mesmo tempo iniciam-se timidamente as migrações para o Sul. Dirigem-se, sobretudo, para a agricultura paulista, mormente para a do café, onde vão substituir o braço imigrante. Essa correlação inversa dos dois fluxos imigratórios é clara nas estatísticas do Departamento de Migração e Colonização de São Paulo, que reunimos no quadro XVII.

\section{Quadro XVII}

Imigração estrangeira e nacional para o Estado de São Paulo, 1820-1960

\begin{tabular}{cccccc} 
& \multicolumn{2}{c}{ Imigrantes } & \multicolumn{2}{c}{ Migrantes nacionais } & Totais \\
1820 eriodos & $N$ & $\%$ & $N$ & $\%$ & 974.177 \\
$1901-1900$ & 973.312 & 99,9 & 965 & 0,1 & 205.297 \\
$1906-1910$ & 193.732 & 94,4 & 11.565 & 5,6 & 200.487 \\
$1911-1915$ & 190.186 & 94,9 & 10.301 & 5,1 & 356.045 \\
$1916-1920$ & 339.026 & 95,2 & 17.019 & 4,8 & 128.539 \\
$1921-1925$ & 100.098 & 77,9 & 28.441 & 22,1 & 279.548 \\
$1926-1930$ & 222.711 & 79,7 & 56.837 & 20,3 & 409.086 \\
$1931-1935$ & 119.204 & 61,9 & 155.821 & 38,1 & 275.446 \\
$1936-1940$ & 56.468 & 43,3 & 156.242 & 56,7 & 350.320 \\
$1941-1945$ & 4.763 & 16,1 & 293.852 & 83,9 & 148.826 \\
$1946-1950$ & 61.030 & 3,2 & 144.063 & 96,8 & 445.389 \\
$1951-1955$ & 210.879 & 13,7 & 384.359 & 86,3 & 973.586 \\
$1956-1960$ & 159.360 & 21,7 & 762.707 & 78,3 & 5.984 \\
Total & 2.883 .934 & 23,5 & 517.624 & 76,5 & \\
& & 53,2 & 2.539 .796 & 46,8 & 5.423 .730
\end{tabular}

Fonte: Departamento de Imigração e Colonização da Secretaria da Agricultura do Estado de São Paulo (apud NOGUEIRA, 1964, p.28).

Somente ao aproximar-se a década dos anos 20 sobe a contribuição do contingente nacional de 5 para 22 por cento. Na década dos anos 30 a imigração estrangeira decresce, primeiro, sob o impacto da crise do café e,

${ }^{61}$ Ver o trecho sobre as migrações dos flagelados em SMITH, 1963, págs.. 166-172. Foi-nos também útil a análise de HIRSCHMAN da ação governamental no Nordeste. Ver em HIRSCHMAN, 1963, o capítulo "Brazil's Northeast", págs. 11-92. 
depois de 1934, com a legislação restritiva do Governo Federal, ao estabelecer o sistema de quotas. Os migrantes nacionais passam a constituir a maioria das entradas no Estado. No período pós-guerra, quando volta a imigração estrangeira em volume significativo, diminui para cerca de $3 / 4$ a parte do total correspondente às migrações nacionais, permanecendo, entretanto, em níveis absolutos altos (mais de meio milhão por qüinqüênio) ${ }^{62}$.

De especial relevância é notar que as migrações nordestinas para fora da região, de fenômeno periódico passa a ser contínuo. Costa Pinto fala sobre o aparecimento de uma ideologia de emigração, consistindo na "generalização da idéia de que sair é melhorar". Escreve ainda o mesmo autor:

Temos a impressão que, originalmente, quando o fenômeno era de menor vulto e esporádico, a emigração de um filho para o Sul era recebida como uma desgraça que recaía sobre uma família, algo comparável ao recrutamento militar (...) [Hoje] não se tem rebuços de falar de emigração como uma esperança de melhores dias e, os que ficam, em regra esperam que o esposo, irmão, pai, parente, compadre, amigo, de lá lhes enviem os meios de partirem também ${ }^{63}$.

\footnotetext{
${ }^{62}$ Observando-se as médias anuais de migrantes para São Paulo, por Estado de origem, apresentadas por Accioly BORGES, 1955 (p.30), para os períodos 1936/40, 1941/45 e 1946/50, verifica-se ser o maior contingente constituído pelos baianos, vindo em segundo lugar os mineiros; seguem com volumes bem menores os provenientes do Nordeste, em geral os alagoanos e pernambucanos primeiro, depois os cearenses e sergipanos. Entre os naturais de outros Estados residentes em São Paulo em 1950, por outro lado, figuram em primeiro lugar, bem na frente, os mineiros, vindo depois os baianos e a seguir os nordestinos (esses mais ou menos naquela mesma ordem, indicada acima) (SMITH, 1963, p.183). Conclui-se dai, primeiramente, que a migração mineira é bem mais antiga que a das outras origens e, em segundo lugar, que apresenta proporções de retomo muito menores. Voltando à questão das áreas de origem dos mirantes, nota-se ainda ser um pequeno número de municípios, em cada caso, responsável por grande proporção dos migrantes do Estado (Accioly BORGES, 1955, p.35); ver também em SMITH, 1963, págs. 177-178, tabela e mapa com a origem de migrantes para São Paulo, no período 1935-1940.

${ }^{63}$ COSTA PINTO, 1952. Seguimos também essa obra nos parágrafos seguintes, na caracterização da influência dos meios de transporte.
}

A constituição da rede de transporte tem papel relevante, não só nas linhas de escoamento, e portanto nas áreas afetadas dos Estados do Leste e do Nordeste, como também no volume mesmo do fluxo migratório. É a proximidade e os transportes mais fáceis que explicam os maiores contingentes mineiros no começo (ver nota 45). Os do Nordeste vinham no início por via marítima (o "Ita" tomado no Norte); a seguir, a pé até as pontas dos trilhos da Central no norte de Minas (em Montes Claros e Pirapora); finalmente chegou, com a estrada de rodagem transnordestina, a era do caminhão e dos "paus-de-arara". Durante todo o tempo, engrossamse cada vez mais as correntes migratórias, difunde-se de boca em boca e pelas cartas vindas de São Paulo, a "ilusão" do Eldorado Paulista.

$\mathrm{O}$ grosso desse movimento dirige-se para a agricultura, para o café e, depois da década dos 20, para o algodão. Importante papel foi e é desempenhado pelo Governo do Estado. É ainda Costa Pinto que escreve:

O aliciamento, a concessão de passagens e o encaminhamento dos trabalhadores às fazendas, foram, entre outras, as formas principais do Governo Paulista manifestar seu interesse em atender à fome de braços dos fazendeiros do Estado.

O papel do novo sistema industrial não se limita a intensificar o fluxo migratório e, pela atração do Centro-sul ${ }^{64}$ e constituição da rede de transportes, a dar àquele fluxo novas direções. Atua também sobre as forças de repulsão, modificando-as e, quase sempre, intensificando-as. Sem pretender estudar o fenômeno a fundo, basta lembrar que em todas as áreas de emigração aumentam as pressões demo gráficas com a queda das taxas de mortalidade (queda menor nas zonas mais atrasadas, mas sempre

\footnotetext{
${ }^{64}$ Pode causar estranheza falar-se em influência do "sistema industrial" e logo a seguir mencionar a "atração do Centro-sul", atração que diretamente se faz sentir a partir da agricultura da região. Deve ser novamente lembrado o sentido em que utilizamos o conceito "sistema industrial" (ver p.2), para indicar a estrutura tecnológica, econômica e demográfica, base da sociedade urbano-industrial que se forma. Essa estrutura engloba extensa divisão do trabalho entre os mais diversos setores do campo e da sociedade. Faz parte dela a teia de transportes e comunicações interligando mercados regionais. $\mathrm{O}$ Centro-sul, com sua agricultura e indústria, é o núcleo mais dinâmico do sistema. Ver atrás trechos pertinentes à agricultura dessa área, às págs. 38-41.
} 
sensível). A mortalidade cai, pela ação do Estado no campo da saúde ${ }^{65}$, ação estatal que se constitui baseada no sistema industrial em desenvolvimento.

No polígono das secas, especificamente, os efeitos das transformações econômicas e sociais do país se fazem notar num duplo sentido, primeiro agravando o problema, aumentando pelos influxos sócioeconômicos sobre a região o desequilíbrio homem-meio, para, a seguir, procurar minorá-lo, pela ação do Estado.

$\mathrm{Na}$ caatinga semi-árida, conforme o demonstra Celso Furtado ${ }^{66}$, as secas transformaram-se em problema social, quando a economia da área passou da pecuária extensiva para mista, juntando à pecuária a cultura do algodão arbóreo (e, necessariamente, a dos produtos de subsistência). O mercado para o algodão, seja o arbóreo da caatinga, seja o herbáceo do agreste, é desde os fins do século passado constituído crescentemente pelas indústrias têxteis do Centro-sul ${ }^{67}$. Resulta dessa alteração econômica do Sertão um adensamento considerável de sua população. Furtado formula o problema de modo dramático:

Essa combinação aparentemente tão feliz da pecuária com o algodão arbóreo modificou as bases da economia sertaneja e transformou as secas em um problema social de grandes dimensões. A população que acorria ao Sertão em busca das vantagens que apresenta a cultura do algodão e seduzida pela abundância de alimentos que ali florescem nos bons "invernos", estava em realidade sendo atraída para uma armadilha infernal (págs. 174-175).

A ação governamental com as "obras contra as secas" acentuou a situação: a construção de açudes (quase sem nenhuma área de irrigação) e

\footnotetext{
${ }^{65}$ Ver, por exemplo, a queda da taxa de mortalidade no caso do interior de São Paulo, de cerca de 20 por mil para 10, entre 1905-1909 e 1955-1959. NOGUEIRA, 1964, p.61. Sobre a transformação da ação do Estado, nas suas relações com o processo de industrialização, ver a $2 .^{\text {a }}$ parte deste trabalho.

${ }^{66}$ Ver FURTADO, 1964, 2. ${ }^{a}$ parte, capítulo 3. ${ }^{\circ}$, especialmente págs. 162-169, e, também, Grupo de Trabalho para o Desenvolvimento do Nordeste, p.65-72. Ver ainda sobre a ação governamental no polígono das secas, HIRSCHMAN, 1963, em particular o trecho "Perception of New Difficulties: Irrigation and Expropriation”, págs. $42-47$.

${ }^{67}$ Cf. SINGER, capítulo "Recife", 1968
}

de estradas, respectivamente, diminuem os danos ao gado e facilitam o seu rápido transporte. As obras, ademais, prendem a mão-de-obra durante a seca perto dos locais de trabalho, mantendo a densidade regional surpreendente $^{68}$. São todas essas condições pelas quais, a partir dos anos 70 do século passado, as secas, segundo Furtado, "deixaram de ser calamidades que dizimavam os rebanhos para transformar-se em autênticas catástrofes sociais" (p.175). A de 1877-79 decorre já da situação criada com a nova economia sertaneja, à qual se juntava a precariedade dos caminhos e a inexistência de auxílio governamental. A partir de então, como vimos, periodicamente o flagelo expulsou do Nordeste, primeiro para a Amazônia depois para o Sul, levas e mais levas de retirantes. Durante a seca de 1958, caracteriza-se um novo quadro com clareza. Reportemo-nos às informações de Hirschman sobre o assunto:

A seca de 1958 foi uma das mais severas jamais ocorridas no Nordeste, particularmente no Ceará, Paraíba e Rio Grande do Norte. Provocou um êxodo sem precedentes das zonas rurais onde as colheitas foram afetadas. Até então o maior número de trabalhadores nas folhas de pagamento do DNOCS havia sido 200.000 durante a seca de 1932. Para as de 1951 e 1953, registra-se 60.000. Em 1958, o DNOCS chegou a empregar 400.000 pessoas e o DNER outras 140.000. Ademais, ocorreu substancial emigração, particularmente para Brasília (...)

E ainda:

O volume do êxodo resultou, em parte, da densidade da rede de estradas e dos progressos nos transportes por caminhões. Ninguém mais ficou para trás para morrer de fome, de sede ou de envenenamento com raízes venenosas ${ }^{69}$.

${ }^{68}$ Para o entendimento dos tipos de ação governamental adotados, é necessário compreender o fato de inserirem-se os grupos de latifundiários do Nordeste na estrutura de poder nacional. Esse ponto é relevante para as nossas preocupações na $2^{\mathrm{a}}$ parte deste trabalho.

${ }^{69}$ HIRSCHMAN, 1963, trecho sobre "The Drought, DNOCS and the 1958 Elections" (págs. 68-72; a citação é da p.68). Comenta ainda esse autor, que esses fatos podem ser interpretados como "o sucesso parcial de certo tipo de ação remediadora; mas é claramente a espécie de sucesso que aumenta, ao invés de diminuir as pressões para reivindicar mais medidas" (p.69). 
As obras do Governo durante as secas, as "frentes de trabalho" abertas com a construção de estradas e de açudes, voltaram a prender à região nordestina, em larga medida, os emigrantes. Isso se deu quando, porém, os fluxos migratórios para o Sul já haviam deixado de ser fenômeno regulado pelas condições mesológicas para tornar-se permanente.

O dinamismo da economia do Centro-sul, as alterações que nela se processam, assim como as transformações de toda a sociedade urbanoindustrial que se constitui em escala nacional, explicam o novo caráter das migrações inter-regionais, o menor peso nelas dos flagelados e por conseguinte a composição diversa da corrente migratória. É provável, por exemplo, que esteja crescendo a porção dessa corrente, a afluir, diretamente ou após uma etapa na zona rural, para o setor urbano da economia, principalmente para o complexo urbano-industrial da cidade de São Paulo e seus arredores.

Baseando-se em dados da Hospedaria dos Imigrantes de São Paulo até 1951, José Francisco Camargo observa que "até muito recentemente o movimento tenderia a se orientar quase exclusivamente para a lavoura paulista" (cerca de 95 por cento davam "agricultor" como sua profissão) ${ }^{70}$. Em estudo realizado em 1956-1958, em uma fábrica paulistana, o autor desta monografia encontrou entre os operários não-qualificados e semiqualificados um quarto constituído por pessoas oriundas do Nordeste e da Bahia. Sobre esses escrevemos:

Os nordestinos da fábrica migraram para o Sul, em geral jovens (16 a 22 anos) e sem intenção de se radicarem fora de sua terra, mas para "conseguirem a vida" e depois voltarem, muitas vezes sós, outras

\footnotetext{
${ }^{70}$ José Francisco de CAMARGO, 1957, p.94. Deve-se notar que nem todos os migrantes passam pela Hospedaria. Accioly BORGES, utilizando além dos dados da Hospedaria o controle estatístico das pessoas colocadas como trabalhadores nas fazendas do interior por intermédio do Serviço de Imigração e Colonização e o registro de desembarque dos passageiros de $3 .^{\mathrm{a}}$ classe em Santos, fornece para 1941-1949 um total de 489.004 migrantes, cerca de sessenta mil a mais do que acusam os registros da Hospedaria. Comparar Accioly BORGES, 1955, p.30, com J. F. CAMARGO, 1957, p.95.
}

com um parente ou conhecido, raramente vieram acompanhados de várias pessoas da família ${ }^{71}$.

E ainda sobre o seu meio de origem:

Os nordestinos (incluindo neste grupo os baianos), em sua maioria, provêm de famílias de sitiantes e, às vezes, de meeiros (...). As [suas] atividades agrícolas (...) aliam-se muitas vezes às comunais. Os chefes das famílias de muitos operários ocupam-se ao mesmo tempo da lavoura e exercem profissões no pequeno meio comunal ${ }^{72}$.

Corroboram esse quadro da migração, e enriquecem o nosso conhecimento sobre o fenômeno, informações de Marvin Harris sobre a emigração de Rio das Contas, na $\mathrm{Bahia}^{73}$, em que compara a que atinge pessoas da cidade (cuja população é de cerca de mil e quinhentos habitantes) às de dois pequenos bairros rurais, nas suas imediações. Os da zona rural são todos agricultores, que premidos pelos'baixos salários locais demandam a agricultura de São Paulo e do Paraná; raramente deixam de voltar para a sua comunidade, e chegam mesmo a participar de migração sazonal para o Sul. Entre os que saem do núcleo urbano, a maioria está desligada da lavoura (embora os que nela trabalham, mais freqüentem ente que no caso dos bairros rurais, sejam trabalhadores sem qualquer terra), vai

\footnotetext{
${ }^{71}$ Note-se que esse fato os distingue do grosso da migração para São Paulo, da qual a maioria se dirige para o interior. No período de 1935 a 1940, mais de 75 por cento tinham vindo em grupos da mesma família. Em 1950 e 1952, verificam-se porcentagens da mesma ordem. Ver SMITH, 1963, p.180, e Accioly BORGES, 1955, p.32. Segundo entrevistas de Celeste de Sousa ANDRADE realizadas na Hospedaria dos Imigrantes, são principalmente os grupos familiares que "vêm compelidos por circunstâncias adversas existentes na região de onde procedem", enquanto o migrante individual, moço e solteiro, embora também venha por motivo de natureza econômica (melhoria de sua situação, juntar dinheiro, etc.), "vem por desejo de vir, mais do Que compelido por uma necessidade premente" (C. de S. ANDRADE, 1952, págs. 123-127). Embora significativa, essa distinção não deve ser exagerada, pois como vimos a repulsão pelo meio de origem multas vezes não surge no nível da consciência (supra, págs. 55-57)

${ }^{72}$ LOPES, 1964, págs. 33, 35 e 37.

${ }^{73}$ HARRIS, 1956, págs. 90-94.
} 
ocupar no Sul empregos urbanos e raras vezes retomam. Num e noutro caso o grosso da migração é constituído de moços solteiros ${ }^{74}$.

É possível que o fluxo migratório das pequenas comunidades semirurais da Bahia e do Nordeste, diretamente para as zonas urbanas do Sul, esteja aumentando. O surto da construção civil durante o pós-guerra, e principalmente na década dos anos 50, o aumento dos serviços semiqualificados nas indústrias tecnicamente mais modernas de São Paulo (onde as funções do processo produtivo foram subdivididas de tal forma que podem ser executadas em pouco tempo por pessoa sem qualquer experiência industrial $)^{75}$, atraem em alta proporção um operariado de origem rural, parte do qual provém do Nordeste. Abrem-se também perspectivas de emprego (ou talvez de subemprego, em situação porém certamente mais atraente da que gozavam na zona rural), em múltiplas ocupações de comércio e "serviços" urbanos. Ter-se-ia engrossado assim o fluxo ruralurbano inter-regional, para as cidades do Sul.

Vemos pois como os condicionamentos básicos dos movimentos inter-regionais do país residem na formação do sistema industrial e nas transformações no seu centro dinâmico. Os fluxos migratórios, por seu turno, trazem repercussões sociais para a sociedade urbano-industrial em desenvolvimento no Brasil e para as partes da nossa sociedade ainda organizadas de forma patrimonialista. Adiante serão considerados tais aspectos do processo. Agora salientaremos apenas os seus efeitos no tocante

\footnotetext{
${ }^{74} \mathrm{O}$ autor informa ainda que 30 por cento dos homens adultos dos bairros rurais na época da pesquisa (1950-1951) estava ou tinha estado trabalhando em São Paulo ou no Paraná. Sobre a migração sazonal escreve: "The trip to Paraná now takes nine or ten days. Formerly this trip would have taken three weeks to a month. Hence it has now become common for the man of Serra do Ouro to 'leave in blocks of ten or twelve, go to São Paulo or Paraná, take part in the harvest, and return to Serra do Ouro in time to plant their own crops". Idem, p.91. Dados para 127 emigrantes da cidade assinalam entre eles 33 agricultores; do total, no Sul, 52 foram ser agricultores, em mais de dez casos as ocupações relacionam-se com emprego em fábrica ou oficinas, noutros dez com a indústria de construção civil (as demais eram parte dos setores de comércio e "serviços" urbanos).

${ }^{75}$ Para uma formulação genérica sobre a evolução da qualificação operária com o progresso tecnológico, ver TOURAINE, 1955, particularmente “Conclusions”, págs. 173-183.
}

a um de nossos temas nessa primeira parte: a constituição do mercado interno.

O mercado é constantemente alargado pelos movimentos interregionais de população, cada vez mais freqüentes. De um lado, significam transferência de trabalhadores de regiões menos integradas para outras mais integradas no mercado, onde surge um salariado mais puro. Accioly Borges salienta esse aspecto:

Há entre nós o vezo de se dramatizar o significado desses enormes deslocamentos populacionais. Poucos se apercebem de que os proprietários de minifúndios, parceiros empobrecidos e assalariados rurais descontentes - todos, enfim, os que constituem o imenso caudal humano atraído pelas áreas urbanas ou zonas pioneiras abandonam uma esfera de economia natural em troca de uma economia mercantil, dando origem, por essa forma, a um mercado interno cada vez mais amplo. São milhões de homens, que passam a comprar, em dinheiro, os produtos necessários à sua subsistência, produtos que antes eles próprios produziam para o seu consumo ${ }^{76}$.

Por outro lado, o contínuo refluxo de migrantes para suas comunidades de origem $^{77}$ significa para essas a introdução de idéias e produtos que, sob o aspecto que ora nos interessa, provocam também a sua gradual integração no mercado.

O que escreve Harris, referente aos bairros rurais de Rio das Contas, é muito significativo:

\footnotetext{
${ }^{76}$ Accioly BORGES, 1955, págs. 8-9. Outro aspecto econômico desse processo é constituir-se assim o setor agrícola de abastecimento urbano num dos estrangulamentos responsáveis pelo surto inflacionário. Com o retardamento do progresso técnico da agricultura, o êxodo rural-urbano com as características apontadas resulta num aumento da demanda de produtos agrícolas maior que o aumento de sua oferta. Daí a melhoria dos preços relativos da agricultura. "Entre 1950 e 1960, o índice de preços do setor agrícola, excluído o café, passou de 100 para 734, enquanto o índice de preços correspondente ao produto passava de 100 para 540.” Plano Trienal, 1962, p.26.

77 Ver nota 57 e também os dados de Accioly BORGES sobre o retomo de migrantes naturais dos vários Estados, pela rodovia Rio-Bahia, nos anos 1950, 1952 e 1953. Taxas de retorno superiores a 50 por cento são freqüentemente atingidas. Accioly BORGES, 1955, p.33.
} 
Depois de trabalhar fora um ano ou dois, o jovem lavrador retorna algo como um herói. Poucos realmente conseguem economizar muita coisa, mas a experiência e os maneirismos ganhos são considerados grandes vantagens. Trazem para casa presentes tais como vitrolas, isqueiros e tecidos de seda. Para si próprios, um grande relógio de pulso, um lenço de seda e a boca cheia de obturações a ouro, que são considerados recompensa suficiente para a aventura ${ }^{78}$.

Intensificam-se as migrações, alteram-se os padrões de gosto e consumo nas comunidades de origem, e abrem-se devagar as economias fechadas de auto-subsistência.

\section{O processo de modernização}

Basta correr os olhos pelas causas das migrações internas apontadas pelos vários estudiosos da questão ${ }^{79}$, para nos tornarmos conscientes da dimensão mais especificamente "social" dos efeitos do desenvolvimento, nas regiões que permaneceram à margem. Quebra-se o isolamento das populações rurícolas. Penetram entre elas aspirações, valores e padrões urbanos. Passam a modificar a fundo as bases mesmas da ordem social tradicional.

O sistema industrial ocasiona tais efeitos, antes de mais nada, através de dois fatos interligados. Primeiramente pela constituição de uma rede de transportes e de comunicações, cada vez mais extensa, aumentando os contatos entre as populações. Aquela rede, no entanto, é constituída, na sua maior parte, por investimentos estatais. Essa reflexão leva-nos a notar ter o Estado brasileiro hoje, comparado ao de há poucas décadas, nova atuação. Devemos procurar compreendê-lo, então, relacionando ao desenvolvimento urbano-industrial, as modificações por ele sofridas. A seguir trataremos da ação do aparelhamento político-administrativo não apenas em sua relação com o setor dinâmico do país, no Centro-sul, mas também nas repercussões que a mesma ação tem sobre as demais regiões, provocando nelas os efeitos a que já aludimos: êxodo rural e desagregação da sociedade tradicional (por sinal, note-se, inter-relacionados).

A análise da mudança social no Brasil, sob essa dupla perspectiva, deveria encarar todas as facetas do papel do Estado na sociedade brasileira, na constituição da infra-estrutura econômica (estradas, energia, siderurgia, etc.), na formulação de um direito trabalhista, ao procurar diminuir as disparidades regionais, no estabelecimento de um sistema educacional, e nas mais variadas regulamentações da atividade econômica.

Ocioso seria dizer que tal tarefa ultrapassa de muito o que é possível realizar nesta monografia. Contentar-nos-emos, com base nos estudos existentes, em examinar os efeitos da atuação do Estado em algumas áreas, como no direito do trabalho e no campo educacional. Por outro lado, não podemos igualmente seguir aqueles efeitos em todas as suas ramificações e teremos de enfocar nosso interesse nalguns dos seus aspectos mais salientes, nas relações de trabalho e no nível dos valores. Esses problemas serão objeto de análise na segunda parte do trabalho.

Por ora, procuraremos obter um quadro preliminar das regiões brasileiras onde o processo de modernização é provavelmente mais intenso. A rede de núcleos urbanos, ligados entre si e às metrópoles, é o suporte tanto para a atuação do Estado como para a difusão das comunicações. A tarefa que nos ocupará no último capítulo dessa parte será pois delinear, com dados sobre tais núcleos, as regiões urbanizadas e não-urbanizadas do Brasil.

\footnotetext{
${ }^{78}$ HARRIS, 1956, p.91.

${ }^{79}$ Ver acima, na p.66.
} 


\section{IV - As áreas urbanizadas e não-urbanizadas do país}

Pretendemos agora obter um primeiro esboço das regiões brasileiras sob as influências urbano-industriais mais intensas, assim como aquilatar os seus efetivos populacionais. Foi o seguinte o procedimento seguido na demarcação dessas áreas em 1950 e na avaliação do aumento delas na década 1950-60. Para os nossos fins era necessário analisar os dados sobre cidades e população urbana por território que fosse mais amplo que o município, menos, entretanto, que o Estado. A unidade intermediária para a qual existem dados é a zona fisiográfica. Essa é, muitas vezes, extensa demais. Era, porém, a que se dispunha e foi a que utilizamos. Por outro lado, era necessário, adotar-se um critério para a: população urbana ${ }^{1}$. Utilizamos o de aglomerações (isto é, as populações dos quadros urbano e suburbano) de um distrito com cinco mil habitantes ou mais, como urbana ${ }^{2}$.

Foram organizadas dessa maneira tabelas para 1950 e 1960, por zonas fisiográficas e por unidade da federação, com dados sobre as cidades existentes (número e contingentes populacionais), segundo o seu tamanho. Adotamos as seguintes classes de cidade: cinco a dez mil, dez a cinqüenta mil e mais de cinqüenta mil habitantes.

${ }^{1} \mathrm{O}$ critério do censo, discriminando a população urbana segundo quadro administrativo (habitantes dos quadros urbano e suburbano do município), é insatisfatório, para os objetivos demográficos e sociológicos. Estudo de MORTARA sobre o censo de 1940 mostra, por exemplo, que em 471 dos distritos municipais existentes em 1940, isto é, quase dez por cento do total, a população do quadro urbano não excedia cem habitantes. Nesse mesmo estudo ele conclui: "Para discriminar com a melhor aproximação possível a população urbana no sentido demográfico e sociológico, pareceu conveniente a adoção do limite de cinco mil habitantes, o que elimina boa parte das populações rurais, as quais ficariam incluídas adotando-se o limite dois mil, sem excluir, de outro lado, nenhum centro demográfico verdadeiramente digno da qualificação de cidade". MORTARA, 1950, p.41. Ver também os estudos incluídos em Pesquisas sobre as populações urbanas e rurais do Brasil, 1954, que utilizam como critério às vezes o limite mínimo de dois mil, às vezes o de cinco mil para a aglomeração urbana. Para os nossos objetivos, pareceu-nos mais interessante demarcar a área onde mais intensamente se faz sentir a Influência de valores, padrões e formas de organização urbanos, adotando o limite de cinco mil.

${ }^{2}$ Note-se que se. Incluíram assim as "cidades" e "vilas", isto é, as sedes de municípios e distritos segundo o censo, com mais de cinco mil habitantes.
Prepararam-se a seguir mapas, onde foram localizadas, por zonas fisiográficas, informações sobre o número de cidades com cinco mil ou mais habitantes e a área em quilômetros quadrados por cidade desse tamanho, assim como a porcentagem da população da zona em cidades de dez mil ou mais. Procurou-se depois delinear as áreas contíguas, com concentração de população urbana. Quando, porém, alguma zona fisiográfica não-urbanizada (com poucas ou nenhuma cidade ${ }^{3}$ ), apresentavase cercada por área urbanizada, ela foi englobada nessa última ${ }^{4}$.

Para 1950 destacam-se, assim, três áreas urbanizadas no país. A principal coincide com o que vimos chamando centro dinâmico do Brasil; é constituída pelos Estados de São Paulo e Rio de Janeiro, pela metade inferior de Minas Gerais e projeta-se pelo norte do Paraná. Incluía 229 cidades; denominamo-la área Rio - Belo Horizonte - São Paulo. A segunda, no Sul, inclui o Rio Grande do Sul e estende-se pelo lado oriental dos Estados de Santa Catarina e Paraná. Estavam aí 65 cidades. A terceira, a Litorânea do Nordeste, estende-se em faixa desde a altura de Ilhéus, na Bahia, até o Estado da Paraíba. Localizavam-se nela 76 cidades 5 . No

${ }^{3}$ Para facilidade de exposição, nessa página e nas seguintes, quando usamos a palavra "cidade", referimo-nos sempre a núcleos com cinco mil habitantes ou mais.

${ }^{4}$ Assim os Estados de São Paulo, Rio Grande do Sul e Rio de Janeiro foram considerados totalmente áreas urbanizadas, embora apresentassem naquela data certo número de zonas "vazias" de cidades. Exemplos: No litoral e na zona limítrofe com O Mato Grosso, no caso de São Paulo, áreas ao norte e na costa, no do Rio Grande do Sul. Aconteceu o mesmo para várias pequenas áreas em outros Estados. Justifica-se esse procedimento, pelo nosso objetivo: traçar as áreas onde a influência urbana é mais intensa.

${ }^{5}$ Essas três áreas eram constituídas dos seguintes Estados e partes de Estado: a área "Rio-Belo Horizonte-São Paulo" formava-se dos Estados de São Paulo e Rio de Janeiro e do Distrito Federal, mais, em Minas Gerais, as Zonas da Mata, Metalúrgica, Oeste, Sul, Alto Paranaíba e Triângulo e, no Paraná, as Zonas do Norte e do Ivaí. A área "Sul" constituía-se do Rio Grande do Sul, de todo o Estado de Santa Catarina, excetuadas as Zonas de Joaçaba e Iguaçu (no oeste do Estado) e, no Paraná, incluía as do Litoral, Planalto de Curitiba, Campos Gerais e a do Irati. A "Litorânea do Nordeste”, finalmente, compunha-se das' Zonas do Litoral e Mata, Agreste e Caatinga Litorânea, Brejo, e Agreste e Caatinga Central (no Paraíba), do Litoral e Mata, e Agreste (em Pernambuco), da do Litoral, Mata e Baixo São Francisco (em Alagoas), do Litoral Norte. Recôncavo, Cacaueira, Feira de Santana, Jequi e Conquista (na Bahia) e do Litoral e Baixo São Francisco (em Sergipe). Serviu- 
conjunto, essas três áreas englobavam naquela data três quartos das cidades e cinco sextos da população urbana do país. Embora representando menos de 14 por cento da superfície total, estavam nelas mais da metade (56 por cento) da população rural e semi-rural brasileira ${ }^{6}$. Nos quadros XVIII e XIX apresentamos as principais informações sobre as populações urbana e rural (junto com a semi-rural), para as várias áreas do Brasil em 1950 e 19607. Além das três áreas urbanizadas, destacamos os seguintes componentes da não-urbanizada: a região Norte, a Centro-Oeste e a parte não-urbanizada das regiões Nordeste, Leste e Sul (subdividida esta última em duas secções, do Maranhão ao Rio Grande do Norte e do Paraíba a Santa Catarina).

Primeiramente, deve-se destacar que as três áreas urbanizadas refletem as principais regiões brasileiras onde a constituição do mercado interno serviu de suporte à industrialização ${ }^{8}$. As interligações das áreas urbanizadas (e dos respectivos mercados) já se deu, com as estradas que ligam o Centro-sul ao extremo-sul e aquele ao Nordeste; mais recentemente com as estradas pelas quais o Centro-sul comunica-se, via Brasília, com o Norte (Belém e Fortaleza). Continuam a existir, porém, largas regiões nãourbanizadas entre as três principais áreas urbanizadas. O norte de Minas, o Espírito Santo e o sul da Bahia, entre a área Litorânea do Nordeste e a RioBelo Horizonte-São Paulo; o Vale da Ribeira e as partes centrais e ocidentais do Paraná e Santa Catarina, entre aquela e a do Sul.

\footnotetext{
nos como base, para o delineamento que fizemos destas áreas urbanizadas, o tratamento do mesmo assunto por GEIGER (1963, págs. 31 e segs.; ver o mapa na p.32).

${ }^{6}$ Entendendo-se por "semi-rural" a população dos núcleos com menos de cinco mil habitantes.

${ }^{7}$ Tentamos fazer coincidir as três áreas urbanizadas em 1960, grosso modo, com os seus limites em 1950, apesar de no intervalo ter havido subdivisão de algumas zonas e, em outras, modificações pequenas em geral nos seus limites. A única mudança apreciável correspondeu à parte do Paraná, da área urbanizada "Rio-Belo Horizonte-São Paulo", onde, devido à alteração nos limites das zonas, tivemos de incluir em 1960 na parte urbanizada, área bem menor que em 1950. (Ver no quadro XX as superfícies, nas datas dos dois censos, das várias áreas em que dividimos o país segundo a urbanização.) Sobre a divisão do Brasil em zonas fisiográficas usada pelo censo em 1950, consultar GUIMARÃES, 1948, págs. 964-965, que a indica em mapa. Para a divisão que serviu de base para o de 1960 usamos mapa existente no Conselho Nacional de Geografia (Secção de São Paulo).

${ }^{8}$ Ver acima, págs. 11-16
}

Quadro XVIII

População urbana e rural, por áreas urbanizadas e não-urbanizadas do país, 1950

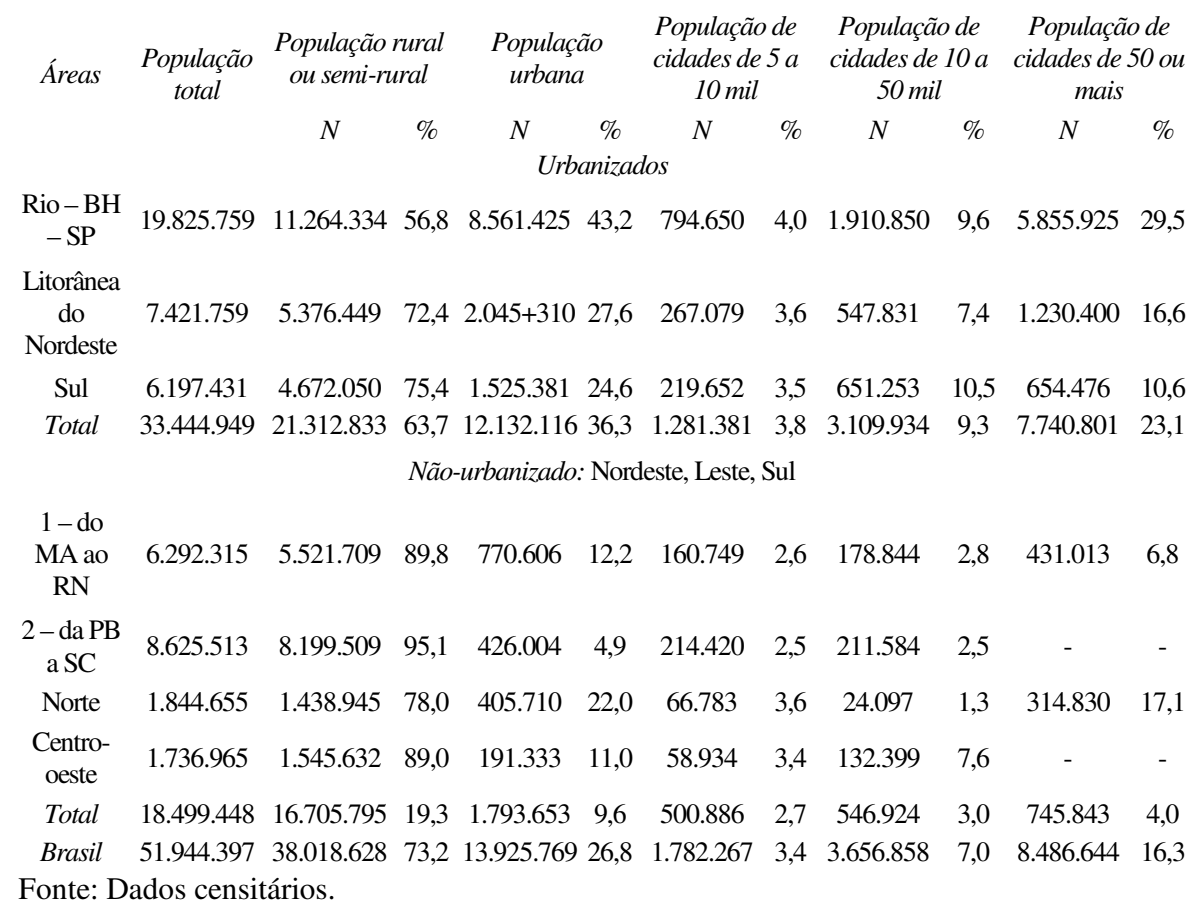

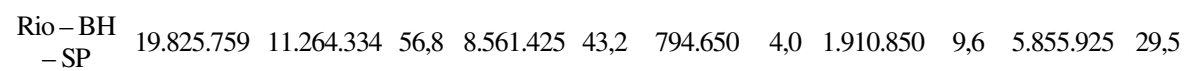
Litorânea

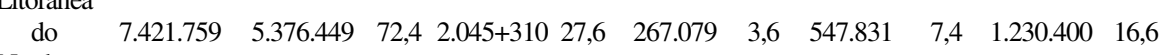
Nordeste

$\begin{array}{llllllllllll}\text { Sul } & 6.197 .431 & 4.672 .050 & 75,4 & 1.525 .381 & 24,6 & 219.652 & 3,5 & 651.253 & 10,5 & 654.476 & 10,6\end{array}$ $\begin{array}{llllllllllll}\text { Total } & 33.444 .949 & 21.312 .833 & 63,7 & 12.132 .116 & 36,3 & 1.281 .381 & 3,8 & 3.109 .934 & 9,3 & 7.740 .801 & 23,1\end{array}$ Não-urbanizado: Nordeste, Leste, Sul

$\begin{array}{llllllllllll}\text { 1-do } & & & & & & & & & & \\ \text { MA ao } & 6.292 .315 & 5.521 .709 & 89,8 & 770.606 & 12,2 & 160.749 & 2,6 & 178.844 & 2,8 & 431.013 & 6,8\end{array}$

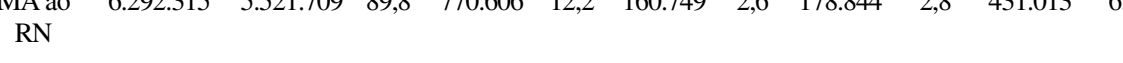

$\begin{array}{cccccccccc}2 \text { - da PB } & 8.625 .513 & 8.199 .509 & 95,1 & 426.004 & 4,9 & 214.420 & 2,5 & 211.584 & 2,5\end{array}$

$\begin{array}{llllllllllll}\text { Norte } & 1.844 .655 & 1.438 .945 & 78,0 & 405.710 & 22,0 & 66.783 & 3,6 & 24.097 & 1,3 & 314.830 & 17,1\end{array}$

$\begin{array}{ccccccccccc}\begin{array}{c}\text { Centro- } \\ \text { oeste }\end{array} & 1.736 .965 & 1.545 .632 & 89,0 & 191.333 & 11,0 & 58.934 & 3,4 & 132.399 & 7,6\end{array}$

$\begin{array}{llllllllllll}\text { Total } & 18.499 .448 & 16.705 .795 & 19,3 & 1.793 .653 & 9,6 & 500.886 & 2,7 & 546.924 & 3,0 & 745.843 & 4,0\end{array}$

$\begin{array}{llllllllllll}\text { Brasil } & 51.944 .397 & 38.018 .628 & 73,2 & 13.925 .769 & 26,8 & 1.782 .267 & 3,4 & 3.656 .858 & 7,0 & 8.486 .644 & 16,3\end{array}$ Fonte: Dados censitários.

Os desníveis de urbanização, como se pode ver pelos mesmos quadros, são pronunciados entre as várias áreas. Em 1950, enquanto a população urbana era superior a um terço do total da população das áreas urbanizadas, no restante do país não chegava a um décimo. Em 1960, as proporções de população urbana das áreas urbanizada e não-urbanizada alcançavam respectivamente quase metade e menos de um sexto da total. Observe-se ainda que a maior parte dos habitantes de cidades está, nas áreas não-urbanizadas, no pequeno número de centros urbanos maiores - ao contrário das urbanizadas, onde existe, além de numerosas cidades grandes, ampla rede de médias e pequenas. Este fato destaca-se ao examinarmos as porcentagens da população em cidades de dez a cinqüenta mil habitantes (9,3 e 3,0 por cento, em 1950, respectivamente, para as áreas urbanizadas e não-urbanizadas; 11,8 e 5,3 por cento, em 1960). 
Ao determos nossa atenção nas várias áreas urbanizadas, surpreendemo-nos com as diferenças quanto à urbanização entre elas. A área Rio-Belo Horizonte-São Paulo destaca-se como a mais urbana do país, bem distanciada das demais. Em 1950, mais de 43 por cento e, em 1960, mais da metade da sua população vivia em cidades com mais de cinco mil habitantes. As outras duas tinham em 1950 cerca de um quarto de sua população como urbana; em 1960, essa proporção era pouco superior a um terço. A urbanização da região Rio-Belo Horizonte-São Paulo não só atinge nível alto, como abrange área considerável, com superfície bem superior a meio milhão de quilômetros quadrados. Já está certamente entre as principais áreas urbanizadas de comparável extensão da América Latina, ficando atrás talvez apenas da região do Rio da Prata.

Quadro XIX

População urbana e rural, por áreas urbanizadas e não-urbanizadas do país, 1960

População Populaçãode Populaçãode Populaçãode urbana cidades de 5 a cidades de 10 a cidades de 50 ou total $\quad N \quad \%$ urbana 10 mil 50 mil Urbanizados

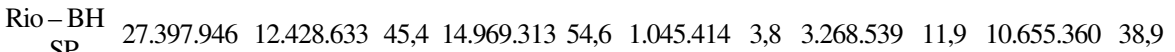
Litorânea

$\begin{array}{llllllllllll}\text { do } & 9.258 .258 & 5.800771 & 627 & 3.457 .487 & 37.3 & 316563 & 3,4 & 922.714 & 10,0 & 2218.210 & 24,0\end{array}$ Nordeste

$\begin{array}{llllllllllll}\text { Sul } & 8.152 .173 & 5.148 .143 & 63,2 & 3.004 .030 & 36,8 & 356.728 & 4,4 & 1.093 .828 & 13,4 & 1.553 .474 & 19,1\end{array}$

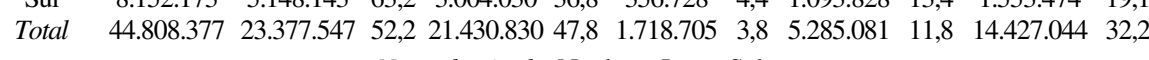
Não-urbanizado: Nordeste, Leste, Su

$\begin{array}{cccccccccccc}\begin{array}{c}1-\text { do } \\ \text { MA ao }\end{array} & 8.250 .621 & 6.754 .882 & 81,9 & 1.495 .739 & 18,1 & 276.366 & 3,3 & 339.588 & 4,1 & 879.785 & 10,7\end{array}$

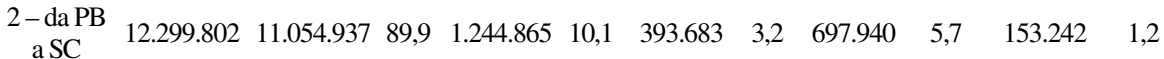

$\begin{array}{lllllllllllll}\text { Norte } & 2.601 .519 & 1.848 .868 & 71,1 & 752.651 & 28,9 & 103.746 & 4,0 & 134.877 & 5,2 & 514.028 & 19,8\end{array}$

$\begin{array}{lllllllllllll}\text { Centro- } & 3.006 .866 & 2.380 .096 & 79,2 & 626.770 & 20,8 & 124.705 & 4,1 & 215.315 & 7,2 & 236.752 & 9,5\end{array}$

$\begin{array}{lllllllllllll}\text { oeste } & 3.00 .86 & 2.380 .158 .808 & 22.038 .783 & 84,2 & 4.120 .025 & 15,7 & 898.500 & 3,4 & 1.387 .718 & 5,3 & 1.833 .807 & 7,0\end{array}$

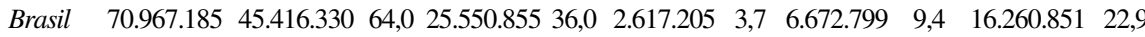
Fonte: Dados censitários.

Os desníveis do grau de urbanização das áreas urbanizadas entre si e em relação às demais mostram-se ainda com maior clareza no quadro XX, onde figuram dados para 1950 e 1960 referentes à densidade urbana ${ }^{9}$ e índice de concentração de cidades (número de $\mathrm{km}^{2}$ por cidade). Em 1950 havia mais de 10 habitantes urbanos por $\mathrm{km}^{2}$ na área urbanizada, enquanto a densidade urbana na não-urbanizada era 0,2 por $\mathrm{km}^{2}$ (em 1960 essa densidade era, respectivamente para as duas áreas, cerca de 19 e 0,6). Outro índice é o número de $\mathrm{km}^{2}$ por cidade: em 1950 pouco mais de três mil na urbanizada e bem mais de sessenta mil no restante do país (em 1960 o índice cai numa e noutra parte, sem alterar muito o desnível: fica sendo, respectivamente, 2.001 e $34.200 .^{10}$

Dois outros fatos devem ainda ser destacados nesse quadro. Primeiro: os mais altos níveis de densidade urbana encontrados entre as áreas urbanizadas são os da área Rio-Belo Horizonte-São Paulo, o Centro-sul, tanto em 1950 como 1960. Comparemo-la com a que apresenta densidade urbana logo abaixo, a litorânea do Nordeste. Em 1950 a primeira tem 14 habitantes urbanos por $\mathrm{km}^{2}$ para pouco mais de 11 para a segunda; em 1960 o Centro-sul distancia-se mais da litorânea do Nordeste: 26 para ela comparados com pouco menos de 20 habitantes por $\mathrm{km}^{2}$, para a outra. Quanto ao índice de concentração de cidades, o Centro-sul, que ficava em 1950 atrás da litorânea do Nordeste, sobrepuja-a em 1960.

O segundo fato a notar é que as áreas urbanizadas do país concentram também mais densamente as suas populações rurais. Enquanto na área nãourbanizada há, em 1950, apenas 2,3 habitantes rurais por $\mathrm{km}^{2}$ (pouco acima de 7, mesmo nas partes dessa área situadas nas regiões Nordeste, Leste e Sul), na urbanizada a densidade rural é superior a 18. (Em 1960, elevaram-

\footnotetext{
9 "Densidade urbana" deve ser entendida como índice de urbanização (relacionando uma população urbana com uma área por onde se espalham as cidades) e não, é claro, como se pode entender "densidade rural".

${ }^{10} \mathrm{Na}$ realidade esse índice é irreal para as Regiões Centro-Oeste e Norte. Nelas temos poucas cidades em estreita parte de cada região e ausência de cidades (e, na verdade, quase ausência de qualquer população) no restante. Mas, mesmo na porção não-urbanizada das regiões Nordeste, Leste e Sul, onde as cidades são mais freqüentes e espalhadas, os índices indicam o fraco nível de urbanização: perto de 21 a 26 mil km² por cidade em 1950; de 11 a 12 mil em 1960. note-se que foi nesta parte, entretanto, que esse índice mais se alterou no decênio, mostrando a expansão da área urbanizada, fato que comentaremos logo abaixo no texto.
} 
se as densidades rurais, sem se alterar basicamente o desnível: 3,0 e 20,5, respectivamente.)

Quadro XX

Densidade rural e urbana, e número de $\mathrm{km}^{2}$ por cidade, por áreas urbanizadas e nãourbanizadas do país, 1950 e 1960

\begin{tabular}{|c|c|c|c|c|c|c|c|c|}
\hline \multirow{3}{*}{$A R B A S$} & \multicolumn{4}{|c|}{1950} & \multicolumn{4}{|c|}{1960} \\
\hline & \multirow{2}{*}{$\begin{array}{c}\text { Superficie } \\
\left(k m^{2}\right)\end{array}$} & \multicolumn{2}{|c|}{ DENSID.ADE: } & \multirow{2}{*}{$\begin{array}{c}N 0^{\circ} \text { de } \mathrm{km}^{2} \\
\text { oor cidade de } \\
5 \text { mil ou } \\
\text { mais }\end{array}$} & \multirow{2}{*}{$\begin{array}{l}\text { Superficie } \\
\left(\mathrm{km}^{2}\right)\end{array}$} & \multicolumn{2}{|c|}{ DENSDDADE } & \multirow{2}{*}{$\mid \begin{array}{c}N .^{\circ} \text { de } \mathrm{km}^{2} \\
\text { por cidade de } \\
5 \text { mil ou } \\
\text { mais }\end{array}$} \\
\hline & & Rural & Urbana & & & Rural & Urbana & \\
\hline \multicolumn{9}{|l|}{ l'rbanizatas } \\
\hline $\mathrm{Rio}-\mathrm{BH}-\mathrm{SP} \ldots \ldots$ & 611.843 & 18,4 & 14,0 & 2.672 & 577.299 & 21,5 & 25,9 & \\
\hline $\begin{array}{l}\text { Litorinea do Nordeste } \\
\text { Sullaten }\end{array}$ & & & 11 , & & & 32 & & 1.709 \\
\hline & & & & & & & & \\
\hline Toт..L.......... & 1.171 .610 & 18,2 & 10,4 & 3.167 & $1.138: 622$ & 20,5 & 18,8 & 2.001 \\
\hline \multirow{4}{*}{ 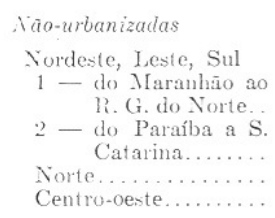 } & & & & & & & ' & \\
\hline & 783.511 & 7,1 & 1,0 & 21.175 & 776.581 & 8,7 & 1,9 & 12.134 \\
\hline & 1.078 .66 .5 & 7,6 & 0,4 & 25.682 & 1.111 .667 & 9,8 & 1,1 & 11.460 \\
\hline & $\begin{array}{l}3.558 .723 \\
1.877 .376\end{array}$ & $\begin{array}{l}0,4 \\
0,8\end{array}$ & $\begin{array}{l}0,1 \\
0,1\end{array}$ & $\begin{array}{l}254.194 \\
134.098\end{array}$ & $\begin{array}{l}3.5 .1 .322 \\
1.879 .399\end{array}$ & $\begin{array}{l}0,5 \\
1,3\end{array}$ & $\begin{array}{l}0,2 \\
0,3\end{array}$ & $\begin{array}{r}147.971 \\
64.806\end{array}$ \\
\hline Total. & 7.298 .265 & 2,3 & 0,2 & 68.208 & 7.318 .969 & 3,0 & 0,6 & 34.200 \\
\hline Bra & 8.469 .885 & 4,5 & 1,6 & 17.756 & 8.457 .591 & 5,4 & 3,0 & 10.802 \\
\hline
\end{tabular}

Fonte: Dados censitários.

Estudemos agora o que ocorre com as cidades e a população urbana, segundo as várias áreas em que dividimos o país, na década de 1950 a 1960. Intensifica-se a urbanização das áreas já urbanizadas ou estende-se para fora dos limites que determinamos para 1950?

Vejamos primeiro o quadro XXI, onde se registram os números e porcentagens de cidades de cada tamanho, segundo a área do país, em 1950 e 1960. Com exceção das maiores, as proporções das cidades de cada tamanho nas três áreas urbanizadas em 1950 diminuíram no decênio. Para toda a área urbanizada, a proporção de todas as cidades cai de 77,6 para 72,7 por cento. (Das cidades de mais de cinqüenta mil habitantes, a porcentagem na área já urbanizada em 1950 permanece, refletindo na realidade um aumento da proporção das cidades desse tamanho do país na área Rio-Belo Horizonte-São Paulo: de menos de 52 por cento em 1950, a ela passou a caber, em 1960, mais de 56 por cento. Nas outras áreas urbanizadas, diminui a proporção de cidades maiores.) Sob esse aspecto número de cidades - percebe-se, portanto, uma extensão da área urbanizada para fora de seus limites em 1950. Os dados desse mesmo quadro dão indicações sobre os lados para os quais se estão dando os prolongamentos da urbanização. Entre as áreas não-urbanizadas, acusam maiores aumentos de cidades, o Centro-Oeste (as cidades aumentam de 14 a 29) e a parte de Paraíba a Santa Catarina das regiões não-urbanizadas do Nordeste, Leste e Sul (onde o aumento é de 42 para 97 cidades).

\section{Quadro XXI}

Número e percentagens de cidades, segundo o tamanho, por áreas urbanizadas e não-urbanizadas do país, 1950 e 1960

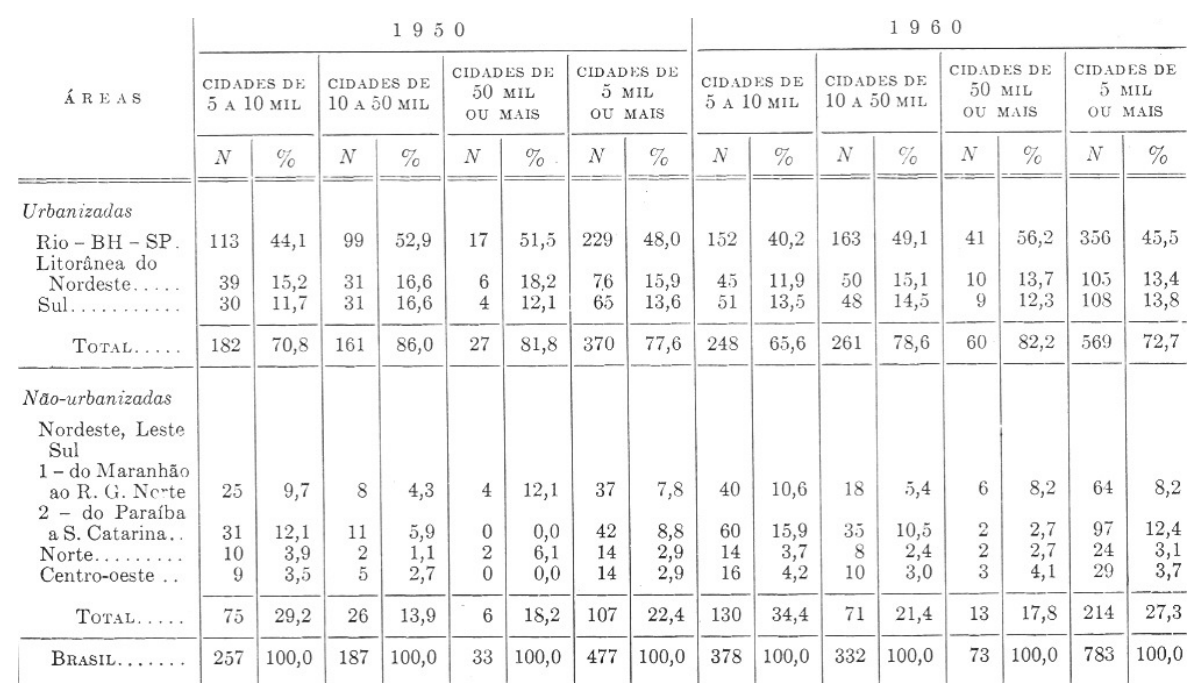

Fonte: Dados censitários.

O quadro XXII permite-nos ver o processo, sob o ângulo do aumento da população urbana. Enquanto ela cresce nas áreas urbanizadas de 77 por cento, nas não-urbanizadas ela bem mais que duplica (130 por cento). $\mathrm{O}$ aumento relativo é maior nas áreas já apontadas: 228 por cento para o Centro-Oeste e 192 para a parte das regiões Nordeste, Leste e Sul que vai de Paraíba a Santa Catarina. Nessas, são ainda as cidades maiores onde se 
verificam os índices de crescimento mais elevados (279 e 302 por cento, respectivamente ${ }^{11}$. Exame mais detido de índices por zonas fisiográficas, assim como preparo de mapa para $1960 \mathrm{com}$ a urbanização por zona, revela as áreas (entre as não-urbanizadas) onde mais cresceram as cidades e a população urbana. Expandiu-se a urbanização para o sul de Goiás, em Minas na direção do Norte, e na Bahia e Pernambuco ao longo do Rio São Francisco. São esses os casos mais frizantes. Trata-se, pois, de expansão das áreas urbanizadas já existentes em 1950, sem lhes alterar substancialmente a feição. Na do Centro-sul, para o sul de Goiás e norte de Minas. Na litorânea do Nordeste, para o Sertão.

\section{Quadro XXI}

Aumento percentual da população rural e urbana, por áreas urbanizadas e nãourbanizadas do país, 1950-1960

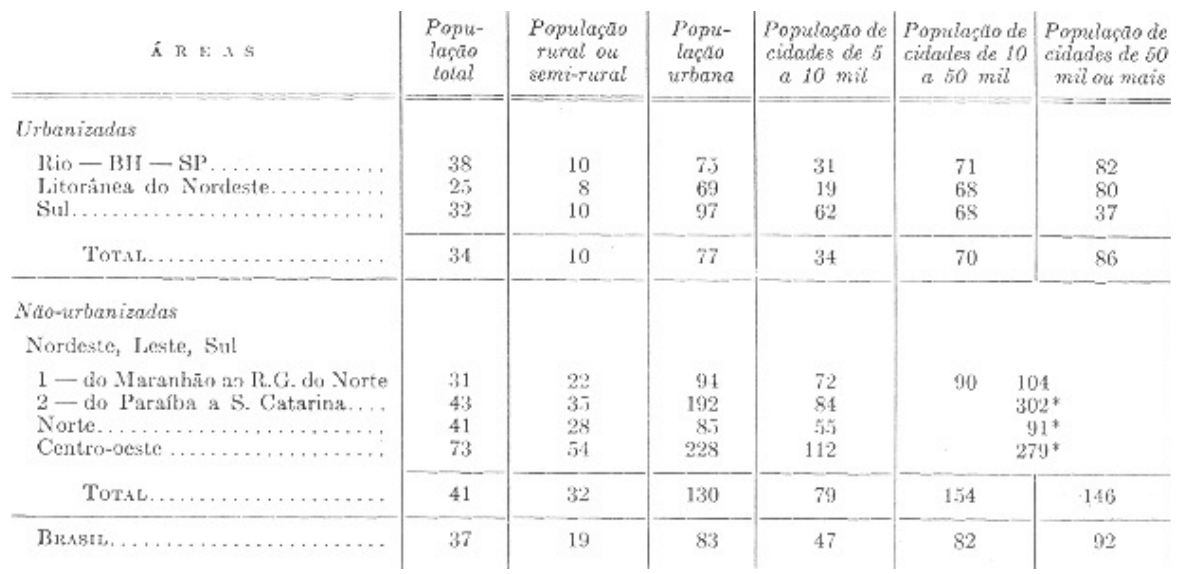

(*) Aumento da população das cidades de 10 mil ou mais habitantes (englobando as de mais de 50 mil); calculou-se dessa forma devido ao pequeno número dessas últimas.

\footnotetext{
${ }^{11}$ Observe-se que enquanto o número das cidades com mais de cinqüenta mil habitantes cresce mais na área Rio-Belo Horizonte-São Paulo, do que em todas as outras, a população dessas cidades cresce bem mais nas áreas não-urbanizadas que naquela área. Conclui-se que nas não-urbanizadas trata-se bem mais nas áreas não-urbanizadas que naquela área. Conclui-se que nas não-urbanizadas trata-se
de crescimento populacional das metrópoles, enquanto na do Centro-sul, de cidades na realidade de tamanho médio.
}

Fonte: Dados dos quadros XVIII e XIX.

No caso da do Sul, parece estar havendo uma cobertura com cidades, de forma mais densa, na metade oriental de Santa Catarina e do Paraná.

A delimitação de áreas urbanizadas, que se fez, equivale na verdade a uma hipótese de trabalho. Pressupomos que as áreas traçadas com base na distribuição de cidades sejam aquelas onde as populações dos núcleos urbanos como as do campo estejam sob a influência mais intensa das metrópoles e do estilo urbano de vida. Não podíamos, dentro do escopo desta monografia, proceder a uma verificação completa dessa pressuposição. Limitamo-nos então ao exame de alguns dados facilmente obteníveis. Eles tendem a confirmá-la. Mencionemo-los. O principal é a análise dos meios modernos de comunicação procedida abaixo, no capítulo $\mathrm{VI}^{12}$. Além disso, com dados do censo de 1950 para Minas Gerais - Estado que se divide, grosso modo, pelo meio em uma parte urbanizada e outra não-urbanizada - verificamos o seguinte:

- calculando-se a porcentagem de estabelecimentos rurais onde os trabalhos agrícolas faziam-se sem emprego de força que não a humana: nas zonas fisiográficas da parte urbanizada essa proporção variava de 62 a 76 por cento; nas da não-urbanizada, com uma exceção (a Zona do Alto São Francisco, onde era de 70 por cento), variavam de 92 a 99 por cento;

- as porcentagens de analfabetos eram, respectivamente, entre homens e mulheres, na zona rural da área urbanizada, de 62 e 71 por cento, e na da não-urbanizada de 81 a 88 por cento (as porcentagens para as cidades e vilas apresentavam diferenças no mesmo sentido, porém, um pouco menores);

- tomando-se apenas os municípios com sedes de população entre cinco e dez mil habitantes: havia 32 nesta categoria na área urbanizada e 8 na não-urbanizada; e comparando-se os primeiros com os últimos havia (anotando-se as diferenças mais significativas) 54 e 66 por cento, respectivamente, de analfabetos; 18 e 14 por cento de pessoas com algum

\footnotetext{
${ }^{12}$ Ver págs. 189-198.
} 
curso completo; e 5 e 8 mulheres no setor terciário para cada uma no secundário $^{13}$.

A nossa divisão em áreas urbanizadas e não-urbanizadas permanece, pois, hipótese parcialmente corroborada. Adotando por conveniência de expressão a forma de afirmação segura, são justificáveis as conclusões do parágrafo abaixo.

Alicerça-se, através das redes urbanas, a sociedade urbano-industrial no Brasil. Nas áreas urbanizadas, intensificam-se as suas influências e acelera-se a transformação social, seja entre a população urbana, seja entre a rural. Permanecem as áreas urbanizadas, entretanto, descontínuas. Vencem os matos, em certa medida, as migrações internas, as comunicações e, sobretudo, a teia de interligações econômicas unificando o mercado e a influência integradora do aparelho político-administrativo do Estado.

\footnotetext{
13 São sugestivas as diferenças de distribuição de índice de conforto doméstico (baseado em elementos da construção e do equipamento da casa, levantado com questionário aplicado a amostras das famílias), para populações urbanas e rurais de cinco dos municípios incluídos no Programa de Cidades-Laboratório do Centro Brasileiro de Pesquisas Educacionais. No caso de Itaituba e Santarém, duas comunidades da Amazônia (escusado dizer, área não-urbanizada), as distribuições do índice para a população urbana tendem a distinguir-se pouco das da rural, confundindo-se ambas num nível baixo. Nos de dois municípios do Sul, Ibirama em Santa Catarina e Júlio de Castilho no Rio Grande do Sul, municípios de antigas zonas de colonização, ocorre o oposto. Embora haja maior diferenciação rural-urbana, as distribuições para ambas as populações tendem para um nível alto. A diferenciação é máxima para as populações rurais e urbanas de Leopoldina, em Minas Gerais (zona urbanizada). Aí quase não há superposição nas duas distribuições. É-se tentado a ver a população de pequenos centros urbanos de áreas não-urbanizadas como a Amazônia como quase rural, enquanto na urbanizada, a diferenciação rural-urbana seria mais nítida, principalmente se considerarmos Leopoldina como mais típica de tais áreas que as duas do Sul. Dados para apenas cinco municípios, repitamo-lo, são apenas sugestivos. Agradecemos ao Prof. Oracy NOGUEIRA ter-nos deixado consultar gráficos correspondentes a esses dados. Sobre o Programa das Cidades-Laboratório, ver D. RIBEIRO, 1958
}

Resumamos brevemente o caminho percorrido na primeira parte. Começando com uma formulação do desenvolvimento industrial brasileiro, em que se acentuou o seu aspecto espacial, vimos como a partir do século passado industrializam-se numerosas cidades, com base em "ilhas" de mercado formadas direta ou indiretamente pela economia exportadora. Com os novos surtos de desenvolvimento industrial, interligaram-se esses mercados e ocorreu intenso processo de concentração fabril na região Centro-sul, que gozava, desde o início, de um maior número de consumidores. Amorteceu-se assim a industrialização das outras regiões, o que não se deu com a sua urbanização. Os efeitos demográficos, econômicos e sociais do Centro-sul (onde de resto se situa agora também a agricultura mais vigorosa) sobre o restante do país, contribuem para a decadência agrícola do Nordeste e do extremo-sul, solapam o artesanato em todo o território nacional e, desses modos e por outros mais sutis, de caráter social, desarraigam as populações rurais e semi-rurais, que passam a constituir um caudal humano em demanda de zonas pioneiras e de cidades em todos os recantos brasileiros. A urbanização alastra-se, desvinculandose do desenvolvimento industrial regional, e diferenciam-se as cidades das zonas adiantadas e atrasadas nas suas características demográficas e econômicas. Terminamos a primeira parte, delineando os contornos das três áreas urbanizadas do país, que abrangem tanto populações urbanas quanto rurais. Tais áreas constituem, presumivelmente, as partes da sociedade brasileira sob o influxo mais intenso do estilo de vida e valores urbanos, que se irradiam a partir das cidades maiores.

Na segunda parte, após caracterizar as transformações da atuação do Estado, nas suas correlações com o desenvolvimento econômico e social (a nova atuação estatal é, a nosso ver, elo básico para a compreensão das mudanças em curso, tanto econômicas como sociais), prosseguiremos com a caracterização dos aspectos sociais da transformação da sociedade brasileira. Primeiramente, no capítulo VI, enfocamos a constituição da sociedade urbano-industrial, com a análise dos processos gerais de mudança do comportamento - a burocratização (nas organizações públicas e privadas), a secularização e a individualização (centrando a atenção nas instituições religiosas e familiais); das alterações na estratificação social; do estabelecimento de teia de contatos e comunicações; e, afinal, da 
transformação de atitudes e valores. No último capítulo, o VII, voltamos o nosso interesse para a desagregação da ordem patrimonialista que sobrevive em largas extensões do Brasil, examinando em particular as relações de trabalho na indústria e agroindústria tradicionais.

O tratamento dos vários assuntos não será uniforme. Demorar-nosemos mais naqueles que não tenham ainda sido analisados sob a perspectiva da formação da sociedade urbano-industrial e sobre os quais haja informações necessárias, pelo menos para uma primeira colocação do problema.

Segunda Parte

\section{Transformações políticas e sociais no Brasil}




\section{V - A transformação política}

A transformação política brasileira neste século é profunda. Interessanos neste livro salientar apenas alguns dos aspectos mais gerais das alterações da estrutura de poder, aqueles que mais importam para o entendimento dos seus vínculos com o desenvolvimento econômico, de um lado, e, do outro, com o desenrolar das mudanças sociais; o que vale dizer, vemos a transformação política como parte integrante do processo global de formação da sociedade urbano-industrial no Brasil ${ }^{1}$.

Os principais contornos da mudança política do Brasil tornam-se claros se se contrasta o período anterior a 1930, caracterizado por uma estrutura oligárquica, com o "Estado composto" e a limitada democracia que prevalecem no pós-guerra².

Observando-se da perspectiva dos últimos sessenta anos a estrutura política brasileira, nos apercebemos da grande transformação sofrida. Contrastemos a situação política recente com um quadro, reconhecidamente simplificado, da vida política na República Velha. Nessa, os protagonistas reais do sistema político eram grupos oligárquicos estaduais ${ }^{3}$, cujo poder repousava, localmente, no poder econômico, social e político dos grandes proprietários de terra, os coronéis. Em última instância, o poder dos coronéis, numa economia predominantemente agrária, derivava da alta

\footnotetext{
1 Tratamos já do mesmo assunto noutros escritos. Ver LOPES, 1967, págs. 96-101, e 1966. Introduzimos, entretanto, modificações de interpretação e de ênfase, e procuramos com maior clareza relacionar a transformação política à mudança social global em curso no Brasil.

${ }^{2}$ Cingimo-nos, a fim de simplificar a argumentação, a umas poucas linhas sobre o período getuliano. Do outro lado, é muito cedo para se dizer até que ponto as ocorrências políticas dos últimos dois anos alteram a análise feita no texto para o período do pós-guerra. Essa análise restringe-se, a rigor embora por comodidade usemos o tempo presente - aos vinte anos de 1945 a 1964.

${ }^{3} \mathrm{O}$ poder da oligarquia derivava em boa medida do controle da administração estadual. Havia grupos locais de oposição, luas eles raramente conseguiam conservar o Governo Municipal que eventualmente houvessem conquistado sem o apoio da oligarquia estadual. Como para a oligarquia fazia pouca ou nenhuma diferença qual o grupo local que a apoiava, a oposição vitoriosa terminava por aderir à oligarquia, arranjo vantajoso para ambos os lados. Ver a discussão deste ponto em NUNES LEAL, 1948, pág.s 25-30. A sua assertiva de que as facções locais "batem-se para disputar, entre si, o privilégio de apoiar o Governo e nele se amparar" (p.29) é fundamental.
}

concentração da propriedade da terra. Denominar a esse sistema coronelismo serve para sublinhar não apenas o fato da preponderância local dos grandes proprietários, mas também o da grande maioria da população não ter qualquer participação política. $\mathrm{O}$ funcionamento das eleições e do sistema representativo em geral - o "voto de cabresto" (voto de lealdade dos rurícolas no candidato do coronel), o voto a descoberto, as atas falsas (eleições "a bico de pena"), o reconhecimento dos eleitos pelo Congresso, a adesão à oligarquia dos candidatos da "oposição", eventualmente eleitos, etc. - esse funcionamento era tal que tudo se passava como se o processo de decisão política se fizesse totalmente dentro da oligarquia estadual e de suas ramificações locais. Não se pode esquecer, entretanto, que nessa situação os chefes políticos municipais, aos quais se vinculavam os coronéis, faziam parte de uma estrutura estadual e que o equilíbrio do poder não pendia do seu lado, mas sim do centro estadual da oligarquia. Como se afirmou acima, os protagonistas da vida política eram grupos oligárquicos estaduais, baseados localmente na influência dos grandes proprietários de terra.

A política nacional consistia num processo de ajustamento e compromisso entre as oligarquias, do qual a política dos governadores era a expressão mais característica, e em cujo processo os grandes Estados tinham a principal voz $^{4}$.

Nesse período, escreve Vieira da Cunha,

(...) a Nação é entendida como um equilíbrio ou armistício entre grupos locais de poder. O poder destes grupos, reconhecido na Monarquia, amplia-se na República a ponto de livremente contraírem os Estados empréstimos no estrangeiro, de cobrirem impostos de

\footnotetext{
${ }^{4}$ A exposição clássica da política dos governadores é a de CAMPOS SALES, que foi um dos seus principais arquitetos. A sua frase, "O que pensam os Estados, pensa a União", resume otimamente essa política (CAMPOS SALES, 1908, p.253). Sobre a preponderância nessa política dos grandes Estados (cafeicultores), escreve A.A. Melo FRANCO: "Na primeira República, a política dos estados foi, no fundo, como não podia deixar de ser, a política dos grandes Estados (...) a produção agrícola, ou antes, cafeeira, que dominava sem concorrência a política brasileira de então, se concentrava predominantemente nos dois Estado e exigia uma correspondente unificação do aparelho político, unificação expressa precisamente no rodízio governativo do dois grandes Estados" (apud OLIVEIRA TÔRRES, 1961, p.218).
} 
exportação, criarem barreiras fiscais e interestaduais e manterem suas próprias Forças Armadas. As instituições político-governamentais nacionais são, não raro, simples emanações dos poderes estaduais Fortalecem-se os presidentes estaduais e, para o necessário entendimento entre eles, forma-se a política dos governadores, em que estes falam pela Nação, entidade abstrata, sem reivindicações próprias, distintas das dos Estados ${ }^{5}$.

Mas novas forças sociais e econômicas estavam evoluindo dentro dessa estrutura política, fazendo-se sentir especialmente na última década da República Velha. Os principais fatores e direções de mudança desde o início do século eram:

1. Os processos de industrialização e urbanização que resultavam na lenta emergência de novas classes sociais: os industriais, uma classe média mais ampla e em parte com setores novos, e o operariado urbano;

2. O fortalecimento do Governo Federal, devido principalmente à crescente preponderância das oligarquias de São Paulo e Minas Gerais e a extensão delas no âmbito nacional da estrutura política.

De um lado, setores urbanos de classe média sentiam-se relegados à margem do processo político. Do outro, tornava-se a política econômica federal mais e mais importante para os interesses que começavam a se diversificar. O controle daquela política era agora crucial - mormente na conjuntura dos anos 20 e ainda mais depois de 1929 - para os Estados produtores de café. De outro lado, o auxílio do Estado a setores em crise passava também a ser reivindicado pelos industriais têxteis. Os compromissos exigidos pela política dos governadores tornavam-se cada

\footnotetext{
${ }^{5}$ A exposição clássica da política dos governadores é a de CAMPOS SALES, que foi um dos seus principais arquitetos. A sua frase, "O que pensam os Estados, pensa a União", resume otimamente essa política (CAMPOS SALES, 1908, p.253). Sobre a preponderância nessa política dos grandes Estados (cafeicultores), escreve A.A. Melo FRANCO: "Na primeira República, a política dos estados foi, no fundo, como não podia deixar de ser, a política dos grandes Estados (...) a produção agrícola, ou antes, cafeeira, que dominava sem concorrência a política brasileira de então, se concentrava predominantemente nos dois Estado e exigia uma correspondente unificação do aparelho político, unificação expressa precisamente no rodízio governativo dos dois grandes Estados" (apud OLIVEIRA TÔRRES, 1961, p.218).
}

vez mais problemáticos. As oligarquias tendiam a cindir-se. De uns e outros fatores resulta o movimento revolucionário que vindo de 1922 culmina em 1930. Na Revolução de Outubro frações das oligarquias, aliadas ao tenentismo - movimento do Exército associado às classes médias urbanas empolgam o poder ${ }^{6}$.

A argumentação, neste ponto, e nos capítulos que se seguem, é em suma que o desenvolvimento econômico que já se dera nessa época - na base de rupturas parciais das ligações da nossa economia exportadora com o mercado mundial - provoca uma industrialização e urbanização; que os novos grupos sociais que surgem (industriais, massas urbanas) condicionam mudanças políticas; que, por seu turno, tais mudanças afetam a continuação e o caráter do próprio desenvolvimento ${ }^{7}$

Para simplificar a argumentação, deixaremos de lado o período getuliano, de 1930 a 1945 . Basta mencionar que, a nosso ver, nesse período encontra-se, paradoxalmente, a fase de gestação (com a emergência das massas urbanas na cena política) da limitada democracia vigente nos anos posteriores a 1945 .

${ }^{6}$ Sobre o caráter de classe média do tenentismo, veja-se SANTA ROSA, 1933, p.114 (apud IANNI, 1965, p.141). O tenentismo na sua origem prende-se à crise militar do período de Bernardes. Nota-se, porém, a sua permeabilização, pouco a pouco, por idéias liberais. Era natural que fossem oficiais do Exército, com a mobilidade geográfica exigida pela sua carreira, que na situação gradualmente se colocassem duma perspectiva divorciada da das oligarquias regionais de base rural, vale dizer, de um angulo urbano (posto de lado pelo jogo político) e nacional. Sobre esse problema, tão mal estudado, são preciosos os documentos coligidos por Hélio SILVA (1964 e 1965). Sobre a importância das modificações econômicas nos anos 20 para o fortalecimento do Governo Federal, ver VIEIRA DA CUNHA, 1963, págs. 18 e segs. A formulação desse autor é especialmente iluminadora quando nota que nesse período "os Estados mais desenvolvidos projetam a sua organização oligárquica no plano nacional" ( $\mathrm{p}$.20) e observa o concomitante acirramento das "divergências internas das oligarquias dominantes" (p.25). No mesmo contexto, é importante toda a análise de FURTADO sobre o mecanismo de "socialização das perdas", via taxa cambial, como. defesa do preço do café, o tornare esse mecanismo insuficiente e a necessidade de ação mais vigorosa por parte do Governo Federal (ver FURTADO, 1959, caps. XXX a XXXII, págs. 207-236). Sobre a diversificação dos interesses econômicos, ver o nosso tratamento adiante, págs. 160-166.

Retomamos o tema, adiante (págs. 155-200). 
O sistema político que surgiu, após a reconstitucionalização do país, era drasticamente diverso do da República Velha. Três são as suas características principais:

1. O foco de poder está não mais nos governos estaduais como antes, mas já então decididamente no âmbito nacional;

2. As massas urbanas têm um papel crucial no processo político;

3. O antigo coronelismo sobrevive, com exceção de numas poucas áreas, enfraquecido e sob formas diferentes ${ }^{8}$.

Examinemos como funciona o sistema político no período recente ${ }^{9}$. Tratemos separadamente o Executivo (tanto no nível federal como no estadual, e no municipal no caso das grandes metrópoles) e o Legislativo (Congresso e assembléias).

Para compreender a eleição do Presidente ou do Governador dos Estados mais urbanizados ${ }^{10}$, é essencial ver o fenômeno do populismo. Nele

\footnotetext{
${ }^{8}$ Sobre a sobrevivência do coronelismo enfraquecido, ver LOPES, 1967; NUNES LEAL, 1948; e J. ${ }^{8}$ Sobre a sobrevivência do coronelismo enfraquecido, ver LOPES, 1967; NUNES LEAL, 1948; e J,
BLONDEL, 1957 (principalmente às págs. 57-72). Este último autor trata da vida política em todo um Estado, o do Paraíba, depois de 1946.

${ }^{9}$ Ver nota 2, acima.

${ }^{10}$ Pode-se tomar, grosso modo, os Estados cujas capitais (sempre a maior cidade do Estado) têm população superior a meio milhão de habitantes. As capitais dos seguintes sete Estados estavam nesse caso, em 1960: São Paulo (3.776.581), Guanabara (3.228.296), Pernambuco (788.580), Minas Gerais (680.025), Bahia (655.739), Rio Grande do Sul (640.173) e Ceará (514.828). Em 1950, somente os três primeiros incluíam-se naquela classe. Atrás apontamos a generalização do crescimento dos centros urbanos nas várias partes do país, crescimento que se dá com características diversas nas regiões mais atrasadas e nas mais adiantadas. Como se verá adiante, há um relativo nivelamento do mundo urbano, no Brasil, no que diz respeito às oportunidades educacionais, ao influxo dos meios modernos de comunicação e, muito possivelmente, a valores prevalecentes entre amplas camadas da sua população (o que significa, entre outras coisas, nivelamento quanto a aspirações). Sugere-se, de imediato, à nossa mente, que o descompasso entre aspirações e oportunidades de emprego (e portanto de consumo) é muito maior nas metrópoles "inchadas" das regiões mais atrasadas do que nas outras regiões, e que disso resultaria um comportamento mais "radical" da massa urbana. Observações superficiais, comparando-se por exemplo São Paulo e Recife, parecem confirmar a idéia. Não há, porém, análise mais profunda do assunto. As correlações feitas por SOARES entre radicalismo e índices de desenvolvimento econômico e social para os Estados brasileiros, embora interessantes, não foram formuladas tendo em vista as questões que aqui se levantam (ver SOARES, 1964 b)
}

reside a verdadeira base da democracia que prevalece no pós-guerra no Brasil. A hegemonia política dos interesses cafeeiros (ou mais precisamente dos setores agro-exportadores) terminou definitivamente. Com a diferenciação econômica e social muito maior que atualmente existe, nenhum grupo da sociedade tomou seu lugar. Há então na política um constante apelo ao "povo", referindo-se implicitamente o termo à população urbana ou, mais precisamente, às suas camadas médias e baixas. Como Weffort afirma corretamente, essas camadas não agem como classes, mas sim como massa indiferençada ${ }^{11}$. Grande parte dessas pessoas - tanto na classe média como nas inferiores - é de origem rural recente. No meio urbano, da impossibilidade de agir na base de laços e padrões tradicionais do seu mundo de origem, resulta extrema pulverização social, no que diz respeito ao comportamento político. Não aparecem associações que medeiem entre os indivíduos e candidatos à Presidência e ao Governo estadual. Os partidos políticos, nesse contexto, podem ser quase completamente desprezados. Estabelece-se uma relação carismática direta entre o líder populista e as massas urbanas ${ }^{12}$.

O povo nessa situação é simplesmente manobrado para aquisição e preservação de poder por líderes que se originam nos grupos das camadas superiores da hierarquia social. Como na Primeira República o povo quase não participa do poder, mas o Executivo tem que o levar em conta. E se vê uma tendência para todo Presidente e Governador, uma vez eleito, qualquer que seja a sua identificação e apoio iniciais, inclinar-se para posições populares ou mesmo assumir certa coloração de esquerda.

No Congresso, especialmente na Câmara dos Deputados, e nas assembléias legislativas, decorre da industrialização e urbanização do país e da muito maior diferenciação da organização social brasileira, do que no

\footnotetext{
${ }^{11}$ Seguimos neste trecho a análise penetrante de WEFFORT da eleição de 1962 na cidade de São Paulo (ver WEFFORT, 1965 a e 1965 b).

${ }^{12} \mathrm{O}$ caráter carismático da relação não quer dizer que não haja vinculações de certos lideres com certas camadas da população (Cf. SOARES, 1965, p.55).
} 
passado, uma representação de interesses e grupos muito mais heterogênea ${ }^{13}$.

A presença continuada do coronelismo no panorama rural do Brasil, embora modificado e mais fraco do que antes de 1930, resulta ainda num grande número de seus representantes nos legislativos: deputados estaduais e federais cuja base eleitoral consiste em boa medida ainda em "votos de cabresto" derivados da influência do proprietário da terra. Pode-se dizer que tudo funciona como se tais proprietários tivessem votos plurais. São esses os deputados como os da República Velha. Com a urbanização e a desagregação da ordem patrimonialista nas áreas atrasadas, o seu número está declinando e o seu comportamento sendo transformado.

Agora, além disso, ao lado deles estão dois novos tipos de deputados - o representante de grupos econômicos e o político de clientela - ambos eleitos, em geral, pela massa crescente de eleitores urbanos. Para compreender esses novos tipos de deputados, assim como as mudanças de comportamento do representante de coronéis, precisamos examinar o papel dos cabos eleitorais urbanos na vida política. Trata-se de intermediários entre a estrutura impessoal da cidade e a gente de um bairro, de uma favela, de um clube recreativo ou esportivo. A maioria das pessoas das classes baixas e médias urbanas é de origem rural recente e não tem $o$ conhecimento, as habilidades e os amigos e parentes para resolverem as suas dificuldades nas grandes cidades. Surgem os cabos eleitorais como intermediários. Da administração municipal e estadual, eles obtêm os serviços para "o seu grupo", tais como conseguir um emprego, um lugar na escola ou no hospital, obter a ligação de água, de eletricidade ou um telefone público em uma rua, ou ainda a mudança de um itinerário de ônibus. Em troca os cabos eleitorais obtêm os votos do grupo para os seus candidatos. Eles são a base sobre a qual repousa a "demagogia" da política urbana. Os políticos fazem promessas concretas às massas e a grupos e

${ }^{13}$ A nossa discussão desse ponto basear-se-á, com algumas modificações, na tipologia de políticos das classes dominantes, feita por SINGER (1965, págs. 71-78). Foi também bastante útil a seção sobre "os processos de demagogia na favela", em estudo recente das favelas cariocas (ver SAGMACS, 1960). indivíduos específicos. Os cabos eleitorais conseguem os votos e o cumprimento pelo menos parcial das promessas. Compreende-se o seu papel, dada a natureza estreita e concreta dos interesses em jogo (e conseqüentemente a completa ausência de questões mais amplas, para não mencionar princípios ideológicos, na política para a eleição do legislativo ${ }^{14}$ ): é o de alguém próximo dos eleitores, nos seus grupos e comunidades primários, capaz de transmitir as promessas dos candidatos através de rede pessoal de contatos e garantir que os eleitores cumpram a sua parte do trato ${ }^{15}$.

Nessa situação, os representantes de grupos econômicos podem facilmente comprar, direta ou indiretamente, os cabos eleitorais, e se elegerem. A influência do dinheiro nas eleições e na política está intimamente ligada ao crescimento do eleitorado urbano e à sua natureza, na fase inicial de uma urbanização extremamente rápida. Os interesses econômicos que são representados dessa maneira são usualmente estreitos; o candidato que assim é eleito para uma assembléia legislativa ou para a Câmara dos Deputados "representa", no geral, uma única empresa ou grupo econômico (muitas vezes um grupo familiar). Não representa geralmente sequer um setor de interesses industriais, de mineração ou de comércio,

${ }^{14}$ Desta análise, conclui-se que, em grande parte, pode-se pôr de lado os partidos políticos para entender as eleições para os legislativos. A correlação entre status sócio-econômico e voto cm certos partidos (cf. SOARES, 1964 a, p.188), a nosso ver, levantam o problema não de preferência partidária, mas o de explicar porque os candidatos de determinados partidos (dos antigos PSP e PTB, por exemplo) usam, mais que os de outros, a rede de cabos eleitorais, os tipos de apelo e o comportamento depois de eleitos que atraem os votos dos eleitores das camadas baixas e médias urbanas. Assim posto, sugere-se logo a hipótese de assim se dar devido aos candidatos dos outros partidos terem já, mais freqüentemente, as suas bases eleitorais nas zonas rurais. A manipulação das massas urbanas era o que sobrava para os que se vinculavam aos novos partidos. Acresce ainda a persistência entre os políticos dos partidos tradicionais, mesmo quando procuram o voto urbano, de orientações e atitudes avessas à manipulação populista. Ver, sobre este último ponto, Os exemplos de WEFFORT (1965 a, p.42), onde este autor nota que "para estes setores [as classes médias tradicionais], a política como tal, perde sentido, pois, como diz Plínio BARRETO, as massas "têm uma irresistível tendência para o pulha",

${ }^{15}$ É notável a similitude com as "máquinas eleitorais" que cresceram nas metrópoles norteamericanas, quando nelas se aglomerava a massa de imigrantes recém-vindos da Europa, Ver, por exemplo, o estudo de WHYTE (1943), particularmente a 2. parte. 
muito menos é porta-voz da Indústria como um todo. Os capitalistas brasileiros não se organizam como classe. O alargamento de interesses representados no sistema político deve ser estudado como parte do processo pelo qual uma classe se forma e se organiza, com o aparecimento de grupos de pressão e de modos de fazer sentir a sua influência de maneira diferenciada, inclusive através dos meios de comunicação ${ }^{16}$.

Outro tipo de deputado é o político de clientela: ele tem papel mediador entre os novos grupos que surgem no meio urbano e a obtenção de facilidades e equipamentos urbanos escassos. Na realidade é um cabo eleitoral maior; aquele cuja clientela (por exemplo um grupo étnico ou os leprosos e suas famílias) é bastante numerosa para elegê-lo. Nos legislativos a sua perspectiva é a mais estreita de todas. Está lá para representar um grupo específico de pessoas. Isso não o prende a quaisquer posições definidas com respeito às questões mais amplas. Daí ser o seu voto, a respeito dessas últimas questões, imprevisível e tortuoso. Tende a se inclinar com a opinião preponderante no momento.

Singer, dada a natureza geral do desenvolvimento brasileiro, com a expansão da empresa capitalista e o papel crescente do Estado na economia, sublinha o ponto básico de tomar-se o representante de grupos econômicos a figura central no processo político. Isso decorre de vários fatos: do financiamento por grupos econômicos da eleição de representantes do coronelismo e de clientelas; do comportamento de troca de votos no legislativo, que naturalmente resulta dos interesses econômicos ou de grupos muito particulares que a maioria dos deputados defende; e do fato de, numa situação em que oportunidades de lucro dependem em alto grau do conhecimento de quais serão as prováveis medidas e diretivas governamentais, muitos representantes de coronéis ou de clientelas

\footnotetext{
${ }^{16}$ Retomamos este ponto adiante, ao tratarmos dos industriais como parte da camada dominante (ver págs. 168-173).
}

passarem a investir em empresas capitalistas e se tornarem assim tipos "mistos" 17.

Vemos, portanto, que o comportamento das massas urbanas, particularmente o eleitoral, é na verdade o fator novo da situação política. $\mathrm{O}$ seu voto para o Legislativo (nos âmbitos municipal, estadual e federal) decorre do modo pelo qual se ajustam eleitores dessas camadas, de origem rural recente, a um mundo urbano, estranho e hostil, ao passo que o seu voto para o Executivo vai, no geral, para um líder carismático populista.

A consequiência é, de um lado, o conflito latente ou aberto, já várias vezes apontado ${ }^{18}$, entre um Congresso conservador, como um todo, e um Executivo muito mais sensível às reivindicações populares. Mais importante ainda é notar (numa situação de ausência quase completa de compromissos dos políticos com princípios gerais e ideologias, ausência explica da em última instância pelas atitudes e comportamento político dos eleitores), que o funcionamento do sistema político resulta naturalmente na formação de "agrupamentos políticos" heterogêneos. Tais agrupamentos cortam as linhas partidárias, extravasam mesmo, na rede de relações que se formam, o mundo da política, e ligam entre si setores agrários, industriais e outros. Os contornos do processo da constituição de tais agrupamentos são claros: 1) formam-se pelo comportamento de troca de votos nas assembléias e câmaras, primeiro numa base $a d$ hoc, dando margem pouco a pouco a compromissos e alianças mais estáveis; 2) prosseguem, nas suas ramificações, com a distribuição, pelo Presidente, governadores e prefeitos, de cargos no Ministério, secretariados e administrações, no esforço de constituírem cada um o seu apoio legislativo, vinculando assim ao topo do

\footnotetext{
17 SINGER, 1965, págs. 78 e segs. De novo, apontando-se apenas essa tendência, deixa-se ele enfrentar o problema básico do processo social, pelo qual "interesses" tornam-se menos particulares, embora continuem - a ser "econômicos". Essa questão liga-se à consideração dos industriais como classe e será retomada, como já mencionamos, adiante.

${ }^{18}$ FURTADO, 1965, págs. 138-139. Esse autor argumenta que, devido ao mecanismo eleitoral, enquanto há preponderância no Congresso de representantes do coronelismo, na eleição do Poder Executivo, no plano nacional e nos Estados mais desenvolvidos, o voto majoritário faz preponderar o eleitorado urbano, concluindo: "As tensões entre os dois centros de poder tenderam a crescer, a ponto de, algumas vezes, traumatizarem a ação do Governo" (p.139).
} 
aparato administrativo amplos grupos de legisladores (e assim os grupos econômicos e os setores do coronelismo por eles "representados"); 3) continuam o seu desenvolvimento pelo entrelaçamento de modo similar de pessoas nos vários níveis de Governo (municipal, estadual e federal).

Do funcionamento quotidiano do sistema político, nascem, portanto, largas redes informais de relações de vereadores, deputados estaduais e federais, ministros, secretários em vários níveis, diretores dos mais variados órgãos de Governo, e assim por diante, baseadas todas na reciprocidade de favores entre políticos, administradores, homens de negócio e coronéis, que tenham interesses se não comuns pelo menos não-conflitantes. Na realidade trata-se do fenômeno, a ser versado em outro capítulo, denominado por Anthony Leeds, em seu estudo, de "panelinha político-econômica" ${ }^{19}$. Nela, note-se, vinculam-se interesses dos setores "tradicionais" e "modernizados" da sociedade brasileira. Como será salientado em maiores detalhes, ao tratarmos do crescimento da máquina burocrática do Estado em uns e outros setores, ambos entrosam-se, em escala nacional, na mesma estrutura de $\operatorname{poder}^{20}$.

Após 1945, por conseguinte, veio a constituir-se no Brasil um "Estado composto", no qual se refletem muitos interesses (ao invés do quase único interesse preponderante do passado) - alguns, "modernos" outros "arcaicos" - que se entrelaçam por acordos e compromissos, e no qual o povo, no sentido dos setores urbanos de nível médio e baixo (sem qualquer orientação claramente de classe), tem de ser levado em conta. A ação econômica e social do Estado tende assim a ser hesitante, errática, tortuosa. Dadas as condições de formação do poder, o Presidente, alguns governadores e deputados mais e mais respondem a interesses populares ${ }^{21}$.

\footnotetext{
${ }^{19}$ Ver págs. 166-167.

${ }^{20}$ Ver adiante, págs. 117 e segs.

${ }^{21}$ Tais interesses não podem ser considerados como dados ou automaticamente derivados das condiçães objetivas do povo. Eles estão sendo definidos num processo de formação de opinião pública, que ocorre nas cidades, tendo por foco as campanhas para os cargos executivos. Nesse processo, que assumia a retórica do "nacionalismo" e "desenvolvimentismo", políticos, intelectuais, estudantes, líderes operários e membros da burguesia industrial, estavam participando de modo
}

A nosso ver pode-se, assim, compreender a feitura de leis 'e regulamentos, com um conteúdo popular, numa situação social e política em que consciência e organização operárias são baixas e agrupamentos políticos de "esquerda" ou "populares" praticamente não têm base social ${ }^{22}$.

Prende-se a formação do "Estado composto" no Brasil ao desenvolvimento econômico que já ocorrera; do outro lado, o funcionamento dessa estrutura do poder nos ajudará a entender a atuação diversa da burocracia estatal nas diferentes regiões brasileiras, a formação de um projeto de industrialização, o comportamento dos empresários industriais, as repercussões do Estado sobre a ordem patrimonialista que ainda subsiste no país, pontos esses versados nos nossos próximos capítulos.

crescente. Para descrição de aspectos da controvérsia política durante os últimos dez anos no Brasil, ver BONILLA, 1963.

${ }^{22}$ Sobre o baixo nível de solidariedade do operariado em São Paulo e a sua relativa incapacidade para ação coletiva da espécie de greves, ver adiante, págs. 173-200. 


\section{VI - A sociedade urbano-industrial em formação}

O nosso estudo da sociedade urbano-industrial em formação no Brasil não poderá, forçosamente, ser exaustivo; incluirá apenas aqueles aspectos que nos parecem de maior relevância. Neste capítulo trataremos dos processos de burocratização, secularização e individualização do comportamento. No próximo, das mudanças na estratificação social e no âmbito das atitudes e valores sociais.

Aqueles processos, em curso no país, são de extrema generalidade e abrangem múltiplos aspectos da vida em sociedade, a todos atingindo profundamente em suas consequiências. São fenômenos ligados às mudanças demográficas, econômicas e políticas até agora examinadas. Não se tratam de processos abstratos, mas de aspectos sociais das formas concretas já delineadas pelas quais a industrialização e a urbanização se deram no Brasil. A burocratização, a secularização e a individualização por que passa a sociedade brasileira são mudanças sociais inter-relacionadas de maneiras específicas, variadas e complexas. Verificam-se em maior profundidade no Centro-sul, a parte mais industrial e urbana do país e, em menor grau, em todas nossas cidades de certo porte. Seus efeitos se fazem sentir, com mais ou menos força, nas áreas rurais e semi-rurais sob a influência urbana ${ }^{1}$. Nesse trabalho não podemos senão apontar, em cada um desses processos, certos aspectos de particular importância e trazer alguns dados relevantes.

\section{A burocratização}

Em artigo de síntese das mudanças sociais recentes no Brasil, Costa Pinto $^{2}$ coloca corretamente a burocratização em dependência da

\footnotetext{
${ }^{1}$ As "áreas urbanizadas", delineadas no capítulo IV.

${ }^{2}$ COSTA PINTO, 1956, págs. 54-65 (as citações são das págs. 57-58). Empregamos (como também o faz COSTA PINTO) "burocratização" e o conceito mais geral "racionalização" no sentido a eles dado por Max WEBER. Ver, particularmente, o capítulo sobre "Burocracia", em Max WEBER, 1944, vol. IV; ver também o nosso artigo sobre WEBER (LOPES, s/d, págs. 71-91).
}

industrialização e urbanização do país e relaciona-a com a emergência da classe média urbana. Citemo-lo:

Concomitantemente com o progresso da industrialização, foi necessário racionalizar a atividade econômica. (...) Ora, essa racionalização das empresas industriais e comerciais produziu nelas uma multiplicação sem conta da hierarquia das funções ou ocupações intermediárias entre os órgãos diretivos e executivos. (...) Além disso, simultaneamente com a burocratização da empresa privada, ocorreu um desenvolvimento em grande escala dos serviços públicos, onde a burocratização também se expandiu profunda e intensamente.

Esse foi o resultado natural da crescente esfera de intervenção do Estado na vida econômica, da extensão da área efetiva abrangi da pela ação governamental e, finalmente, da ampliação inexorável do programa administrativo do país que, por seu turno, era a conseqüência lógica da crescente taxa de desenvolvimento do Brasil (...)

E assinala ainda Costa Pinto:

(...) a penetração do burocratismo na empresa privada e no serviço público originou uma classe média urbana no Brasil, ocorrência de data relativamente recente na nossa estrutura social.

São essas de fato as linhas mestras da evolução do fenômeno. O capitalismo industrial em transformação provoca-o aqui, como em outros países. Por ora, nós o examinaremos mais detidamente nos seus aspectos mais gerais, juntando alguns dados pertinentes. Mais adiante, num e noutro passo, salientaremos a sua feição mais específica, explicável pela forma concreta com que entre nós se está dando o desenvolvimento ${ }^{3}$.

Os começos da racionalização do trabalho e da burocratização na esfera econômica surgem com o próprio capitalismo industrial, principalmente na passagem da indústria a domicílio para a fábrica ${ }^{4}$. Esses

\footnotetext{
${ }^{3}$ Ver, por exemplo, abaixo, págs. 111 e segs.

4 Reinhard BENDIX sumaria bem esse processo de burocratização interna da empresa, principalmente no que concerne à administração da mão-de-obra. Escreve ele: "Subcontracting typically involved a contract between a merchant enterpriser and one or several subcontractors, in
} 
processos acentuam-se enormemente, entretanto, quando as grandes sociedades anônimas se tomam dominantes, durante o período da "Segunda Revolução Industrial”, no último quartel do século XIX ${ }^{5}$. Dois aspectos das transformações da organização das empresas são especialmente relevantes para o processo de burocratização, aspectos que se simbolizam nas figuras do operador de máquinas e do técnico de planejamento e controle da produção. Noutro trabalho assim os caracterizamos:

A racionalização do trabalho, ao se findar o século XIX exemplificada pelo taylorismo, e, mais tarde, a introdução de formas de produção em massa, têm o mesmo sentido. Resultam na segmentação progressiva do trabalho industrial, até a sua quase completa decomposição em operações elementares unidas pela linha de produção. Ao lado de máquinas cada vez mais especializadas, coloca-se uma mão-de-obra cada vez menos qualificada, não sendo os operários mais do que "cuidadores de máquinas", que, com pouco treino, podem ser transferidos de um serviço para outro: seu trabalho exige apenas destreza e não qualificação verdadeira. Esta mudança realmente consistiu na separação, nos trabalhos industriais, da função de planejamento da de execução. Ao mesmo tempo em que os trabalhadores manuais se nivelavam num mesmo plano de semiqualificação, criava-se um exército de supervisores, de toda ordem de técnicos, de administradores e de empregados de escritório ${ }^{6}$.

which the latter obliged themselves to deliver a given quantity of goods at a stipulated quality and price. The organization of labor and sometimes also of production was left to the subcontractors. Today, subcontracting in this sense has disappeared completely from industries which require heavy capital investments, the concentration of operations in single plants and highly technical as well as long run planning of production. Most of the functions which the subcontractors performed have been assigned to separate departments, and the immediate foreman of the workers has retained only the function of direct supervision". BENDIX, 1956, 2. ${ }^{\text {a }}$ parte ("The Bureaucratization of Economic Enterprises”), em especial as págs. 211-244 (a citação é das págs. 212-213).

5 Ver, sobre a "Segunda Revolução Industrial", FRIEDMANN, 1946, págs. 13-25 e H. PASDERMADJAN, 1959

${ }^{6}$ Ver LOPES, 1964, capítulo VI (“Sistema Industrial e Estratificação Social”), págs. 162-183 (a citação é da pág, 170).
Não será demais lembrarmos que com a separação mais nítida, no interior da empresa, do planejamento da execução das tarefas, atinge-se grau mais elevado do seu controle, seja das tarefas do operário semiqualificado seja das do técnico, maior previsibilidade, em suma, maior racionalização de todas as operações. Processo semelhante ocorre nos outros setores da vida econômica, no comércio, nos bancos, etc. "O índice mais útil" - assevera Bendix - "da burocratização interna das empresas econômicas é a proporção de empregados administrativos (salaried employees) na estrutura ocupacional de um país" ${ }^{7}$.

No Brasil, empresas racionalizadas, características daquela fase do capitalismo, datam do período pós-guerra. São marcos básicos a instalação nesse período dos princípios da indústria de bens de produção e na década dos anos 50, a da automobilística. Essa última representou a introdução de novos padrões tecnológicos e de organização, não apenas nas fábricas de montagem, mas sob a sua influência em todo o parque das indústrias mecânicas e metalúrgicas.

Todos esses ramos "modernizados" da indústria concentraram-se, ainda mais que todo o setor industrial, no Centro-sul, sobretudo na região do "Grande São Paulo" 8 . No Centro-sul, e em especial em São Paulo, acentua-se a burocratização.

No quadro XXIII, relacionamos alguns dados, para 1959-60, indicadores do grau de burocratização da indústria dos Estados onde ela tem certa importância. Note-se, primeiramente, as porcentagens dos estabelecimentos maiores (com pessoal ocupado superior a cem) nos totais. Para São Paulo, Guanabara, Rio de Janeiro e Pernambuco, a proporção desses estabelecimentos é acima de 3 por cento. Para todos esses Estados, em segundo lugar, os estabelecimentos maiores são responsáveis por elevada parte de todo o operariado e do valor total da transformação industrial do Estado (cerca de dois terços ou mais). (Pernambuco, entretanto, constitui caso particular, pois essas características devem-se

${ }^{7}$ BENDIX, 1956, p.211

${ }^{8}$ SINGER, capítulo "São Paulo", 1968 
provavelmente às usinas, agroindústrias muitas vezes de grandes dimensões, porém, com certeza de grau relativamente baixo de racionalização.) Em Minas Gerais, embora os grandes estabelecimentos constituam parcela menor (1,6 por cento), eles são de tamanho médio maior e perfazem bem mais do que metade do operariado e do valor da transformação industrial totais do Estado. Outro dado a refletir os níveis tecnológico e de racionalização mais elevados das empresas industriais maiores dos Estados do Centro-sul, é o seu elevado valor médio da transformação industrial ${ }^{9}$.

Para os outros Estados, os estabelecimentos maiores são baixa proporção do total e compreendem baixa parcela (cerca de 40 por cento ou menos) do operariado e do valor da transformação industrial totais. São grandes empresas - veja-se os dados de tamanho médio, - porém, raras na paisagem industrial do Estado.

Tudo está a indicar a alta concentração de estabelecimentos de elevado grau de racionalização (e burocratização) no Centro-sul, abarcando parcela considerável do operariado da região e do valor da transformação industrial nela realizada ${ }^{10}$. Pequeno número de grandes empresas, onde houve avanços pronunciados de racionalização (em geral menores do que nas do Centro-sul), espalham-se pelos outros Estados brasileiros.

\footnotetext{
${ }^{9}$ É interessante notar que esse índice dá nível bem elevado para o pequeno número de empresas baianas de grande porte.

${ }^{10}$ Outra maneira de ressaltar essa concentração é apontando-se que, enquanto nos quatro Estados do Centro-sul (São Paulo, Guanabara, Rio de Janeiro e Minas Gerais) estão pouco mais de metade dos estabelecimentos industriais de todos os tamanhos e de dois terços do operariado total, a proporção para as empresas com pessoal ocupado superior a cem é, em ambos os casos, acima de 80 por cento. São Paulo sozinho tem mais da metade dos estabelecimentos e dos operários do país nessa última classe de tamanho.
}

Quadro XXIII

Características dos estabelecimentos industriais maiores (*), para os principais Estados, 1959-1960

\begin{tabular}{|c|c|c|c|c|c|c|c|}
\hline \multirow{3}{*}{ ESTADO } & \multicolumn{3}{|c|}{$\begin{array}{l}\text { ESTABELECIMENTOS } \\
\text { INDUSTRIAIS }\end{array}$} & \multicolumn{2}{|c|}{$\begin{array}{l}\text { DADOS PARA OS FSTABELECI- } \\
\text { MENTOS MAIORFS(*), ,MI } \\
\text { PORCENTAGEM DO TOT.LL }\end{array}$} & \multicolumn{2}{|c|}{$\begin{array}{c}\text { VALORES MÉDIOS PARA OS } \\
\text { ESTABELECIMENTOS } \\
\text { MAIORES (*) }\end{array}$} \\
\hline & \multirow{2}{*}{ TотAL } & \multicolumn{2}{|c|}{$\begin{array}{c}\text { Estabelecimentos } \\
\text { maiores }(*)\end{array}$} & \multirow{2}{*}{\begin{tabular}{|c} 
Porcentagem \\
dos \\
operários
\end{tabular}} & \multirow{2}{*}{$\begin{array}{l}\text { Porcentagem } \\
\text { do valor da } \\
\text { transformasaso } \\
\text { industrial }\end{array}$} & \multirow{2}{*}{$\begin{array}{l}\text { Tamanho } \\
\text { médio } \\
\text { (operarios) }\end{array}$} & \multirow{2}{*}{$\begin{array}{l}\text { Valor médio da } \\
\text { transformaçáa } \\
\text { industralal } \\
\text { (milhöes de Crs }\end{array}$} \\
\hline & & $\mathrm{N}$ & $\%$ & & & & \\
\hline São Paulo. & 36.129 & 1.439 & 4,0 & 63,1 & 69,7 & 302 & 144 \\
\hline Guanabara... & 5.306 & 316 & 6,0 & 61,4 & 70,0 & 273 & 12.5 \\
\hline Rio Grande do Sul & 12.582 & 195 & 1,5 & 38,6 & 44,6 & 234 & 87 \\
\hline Rio de Janeiro..... & 4.534 & 171 & 3,8 & 72,0 & 81,5 & 399 & 187 \\
\hline Minas Gerais....... & 12.259 & 191 & 1,6 & 54,5 & 57,9 & 352 & 102 \\
\hline Paraná......... & 6.403 & 72 & 1,1 & 30,6 & 24,3 & 246 & 60 \\
\hline Pernambuco........ & 3.599 & 112 & 3,1 & 67,0 & 72,7 & 364 & 93 \\
\hline Santa Catarina.... & 5.906 & 81 & 1,4 & 45,7 & $4 . \overline{5}, 6$ & 347 & 74 \\
\hline Bahia.............. & 5.929 & 48 & 0,8 & 36,7 & 71,8 & 298 & 201 \\
\hline Demais Estados... & 17.692 & 150 & 0,8 & 35,4 & 37,5 & 295 & 6.5 \\
\hline Br.ASIL ..... & 110.339 & 2.775 & 2,5 & 56,1 & 64,7 & 305 & 128 \\
\hline
\end{tabular}

(*) Estabelecimentos com "pessoal ocupado" de cem ou mais indivíduos.

Fonte: Censo Industrial de 1960 (Anuário Estatístico do Brasil, 1963).

Trata-se, porém, de verificar a marcha do processo de burocratização. Para tanto, mais significativo do que tamanho é a relação sugerida por Bendix do pessoal administrativo (salaried persornnel) em porcentagem do empregado na produção (wage earners).

A Secretaria Geral do Conselho Nacional de Estatística coletou para vários anos as informações necessárias, referentes a estabelecimentos além de certo tamanho mínimo ${ }^{11}$. Com base nesses dados organizamos o quadro XXIV.

\footnotetext{
${ }^{11}$ Estabelecimentos com volume de vendas não-inferior, em 1944, a cem mil e, em 1954, a duzentos mil cruzeiros. A elevação do limite mínimo deveu-se, é claro, à inflação de preços. Não resultou, portanto, na inclusão em 1954 de estabelecimentos de fato maiores. Pelo contrário, o tamanho médio das empresas incluídas nesse último ano foi quase sempre menor do que em 1944, como pode ser observado pelo quadro.
} 
Quadro XXIV

Burocratização (relação A/P) da indústria das principais capitais do Brasil, 1944 e 1954

\begin{tabular}{|c|c|c|c|c|c|c|c|c|c|}
\hline \multirow[b]{3}{*}{ CAPITAL } & & \multirow{3}{*}{ 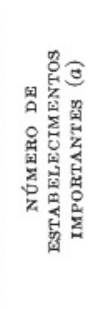 } & \multirow{3}{*}{ 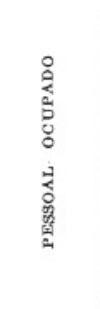 } & \multirow{3}{*}{ 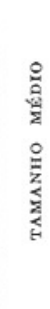 } & \multicolumn{4}{|c|}{$\begin{array}{l}\text { DISTRIBUTCEAO PERCEN- } \\
\text { TUAL DO PESSOAL OCUPADO }\end{array}$} & \multirow[b]{3}{*}{ 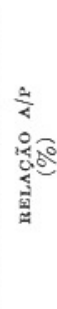 } \\
\hline & & & & & \multirow[b]{2}{*}{ 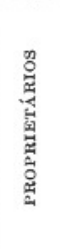 } & \multicolumn{2}{|c|}{ A } & \multirow{2}{*}{ 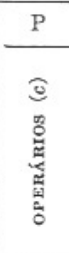 } & \\
\hline & & & & & & 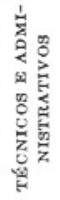 & 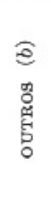 & & \\
\hline Paulo $(d)$. & $\begin{array}{l}1944 \\
1954\end{array}$ & $\begin{array}{l}3.549 \\
6.042\end{array}$ & $\begin{array}{l}279.684 \\
439.111\end{array}$ & $\begin{array}{l}79 \\
73\end{array}$ & $\begin{array}{l}2,4 \\
2,2\end{array}$ & $\begin{array}{r}9,7 \\
12,9\end{array}$ & $\begin{array}{l}2,7 \\
1,7\end{array}$ & $\begin{array}{l}85,2 \\
83,2\end{array}$ & $\begin{array}{l}14,6 \\
17,5\end{array}$ \\
\hline R. de Janeiro (e) & $\begin{array}{l}1944 \\
1954\end{array}$ & $\begin{array}{l}2.321 \\
3.557\end{array}$ & $\begin{array}{l}166.059 \\
230.287\end{array}$ & $\begin{array}{l}72 \\
65\end{array}$ & $\begin{array}{l}2,9 \\
2,7\end{array}$ & $\begin{array}{r}9,7 \\
13,1\end{array}$ & $\begin{array}{l}3,6 \\
3,0\end{array}$ & $\begin{array}{l}83,8 \\
81,2\end{array}$ & $\begin{array}{l}15,9 \\
19,8\end{array}$ \\
\hline Porto Alegre... & $\begin{array}{l}1944 \\
1954\end{array}$ & $\begin{array}{l}222 \\
456\end{array}$ & $\begin{array}{l}16.286 \\
28.681\end{array}$ & $\begin{array}{l}73 \\
63\end{array}$ & $\begin{array}{l}2,8 \\
2,8\end{array}$ & $\begin{array}{r}9,0 \\
11,9\end{array}$ & $\begin{array}{l}3,6 \\
2,3\end{array}$ & $\begin{array}{l}84,7 \\
83,0\end{array}$ & $\begin{array}{l}14,9 \\
17,1\end{array}$ \\
\hline Recife.......... & $\begin{array}{l}1944 \\
1954\end{array}$ & $\begin{array}{l}253 \\
185\end{array}$ & $\begin{array}{l}25.634 \\
25.443\end{array}$ & $\begin{array}{l}101 \\
138\end{array}$ & $\begin{array}{l}1,9 \\
1,2\end{array}$ & $\begin{array}{r}7,5 \\
10,1\end{array}$ & $\begin{array}{l}1,7 \\
1,8\end{array}$ & $\begin{array}{l}88,9 \\
86,9\end{array}$ & $\begin{array}{l}10,3 \\
13,7\end{array}$ \\
\hline Belo Horizonte. & $\begin{array}{l}1944 \\
1954\end{array}$ & $\begin{array}{l}192 \\
389\end{array}$ & $\begin{array}{l}11.858 \\
18.724\end{array}$ & $\begin{array}{l}62 \\
48\end{array}$ & $\begin{array}{l}3,2 \\
3,3\end{array}$ & $\begin{array}{r}7,6 \\
10,3\end{array}$ & $\begin{array}{l}2,6 \\
1,3\end{array}$ & $\begin{array}{l}86,6 \\
85,1\end{array}$ & $\begin{array}{l}11,5 \\
13,6\end{array}$ \\
\hline Salvador.. & $\begin{array}{l}1944 \\
1954\end{array}$ & $\begin{array}{r}87 \\
269\end{array}$ & $\begin{array}{r}9.194 \\
15.303\end{array}$ & $\begin{array}{r}106 \\
57\end{array}$ & $\begin{array}{l}1,7 \\
2,9\end{array}$ & $\begin{array}{r}6,6 \\
10,0\end{array}$ & $\begin{array}{l}1,1 \\
2,1\end{array}$ & $\begin{array}{l}90,6 \\
85,0\end{array}$ & $\begin{array}{r}8,5 \\
14,2\end{array}$ \\
\hline Curitibs......... & $\begin{array}{l}1944 \\
1954\end{array}$ & $\begin{array}{l}177 \\
239\end{array}$ & $\begin{array}{r}9.717 \\
14.564\end{array}$ & $\begin{array}{l}55 \\
61\end{array}$ & $\begin{array}{l}3,8 \\
3,3\end{array}$ & $\begin{array}{l}8,8 \\
9,8\end{array}$ & $\begin{array}{l}3,6 \\
1,7\end{array}$ & $\begin{array}{l}83,8 \\
85,1\end{array}$ & $\begin{array}{l}14,8 \\
13,5\end{array}$ \\
\hline Brasti $(f) \ldots$ & $\begin{array}{l}1944 \\
1954\end{array}$ & $\begin{array}{r}7.217 \\
11.841\end{array}$ & $\begin{array}{l}550.804 \\
807.823\end{array}$ & $\begin{array}{l}76 \\
68\end{array}$ & $\begin{array}{l}2,6 \\
2,5\end{array}$ & $\begin{array}{r}9,2 \\
12,4\end{array}$ & $\begin{array}{l}2,8 \\
2,1\end{array}$ & $\begin{array}{l}85,3 \\
83,0\end{array}$ & $\begin{array}{l}14,1 \\
17,5\end{array}$ \\
\hline
\end{tabular}

(a) Abrange os estabelecimentos com total de vendas em 1944 não-inferior a cem mil cruzeiros e, em 1954, não-inferior a duzentos mil cruzeiros.

(b) Viajantes, compradores, caixeiros e vendedores.

(c) Operários, pessoal de transporte e trabalhadores braçais.

(d) Inclusive Santo André.

(e) Inclusive Niterói e São Gonçalo.

(f) Incluindo todas as demais capitais.

Fonte: Secretaria Geral do Conselho Nacional de Estatística (apud Anuário Estatístico do Brasil - 1946 e 1955).

Nele pode-se constatar que para todos os Estados a relação A/P, o pessoal administrativo em porcentagem do que está na produção, aumenta de 1944 a 1954. Para as empresas de todo o Brasil, eleva-se de 14,1 para 17,5 por cento. A tendência, com uma única exceção, é a mesma em todos os Estados. Nota-se logo ser o pessoal técnico e administrativo o responsável pela tendência; a proporção de empregados em funções de compra e venda (os "outros" do quadro), pelo contrário, em geral diminui. (Aliás, é essa categoria que explica o comportamento anômalo das indústrias de Curitiba, pois nelas a sua proporção é desusadamente elevada e acusa pronunciada queda nos dez anos considerados.) Ademais, observe-se que a diminuição relativa dos proprietários e do pessoal em funções comerciais, indica provavelmente a concentração econômica das empresas, por meio da qual se realiza a sua racionalização.

Assinale-se que a instalação de empresas com organização e tecnologia mais avançadas faz-se em ritmo mais intenso depois de 1954 e por conseguinte é a partir dessa data que cresce sua influência sobre todo o parque industrial. Conclui-se que, de acordo com aquele índice de burocratização ${ }^{12}$, o processo é geral e acelera-se no país. Ele atingiu níveis bem mais altos nas empresas de São Paulo e do Rio, onde as proporções de técnicos e pessoal administrativo nos estabelecimentos industriais chegam perto de 13 por cento.

${ }^{12}$ BENDIX apresenta em seu livro dados sobre essa relação (onde exclui do pessoal administrativo, além dos proprietários, os membros da alta administração), para os EUA e diversos países europeus. As porcentagens em todos os casos aumentam, quase sem irregularidades de ano para ano: para os EUA, de 7,7 para 21,6\% (1899-1947), para a França, de 11,8 para 14,6\% (1901-1936), para a GrãBretanha, de 8,6 para 20,0\% (1907-1948), para a Alemanha, de 4,8 para 14,0\% (1895-1933) e para a Suécia, de 6,6 para 21,0\% (1915-1950). (BENDIX, 1956, p.214.) (Compare-se com os dados equivalentes para o Brasil em 1944 e 1954: 14,1 e 17,5). Ao discutir as razões do aumento da relação A/P, aquele autor salienta a burocratização da direção (management) das empresas econômicas. (Veja-se o seguinte trecho: “(...) in the smallest enterprise the major problem involves the division of work among the owner-manager, perhaps some member of his family, and a few employees. As the enterprise increases in size, it becomes necessary for the owner-manager to delegate to subordinates responsibility for many functions, which he has performed personally in the past. Subsequently, it becomes necessary to delegate further managerial functions, and the problem arises how to do this without overburdening the chief executive officer of the company (span of control). With further increases in size this problem is solved in part by making one or several staff assistants available to the executive so that his energies can be concentrated on the essential tasks of his position", etc.) (BENDIX, 1956, págs. 226-227.) Não devemos nos esquecer, porém, do aumento de técnicos e engenheiros decorrente das alterações que se operam na organização do processo produtivo nas oficinas, do tipo do taylorismo e da produção em série, o que também contribui para elevação da relação $\mathrm{A} / \mathrm{P}$. 
No Centro-sul, os vários ramos industriais, embora evoluam no mesmo sentido, apresentam ritmos diferentes de racionalização. Este fato, e ainda a proeminência cada vez maior da mão-de-obra semiqualificada, no período mais recente (1951-1963), ressaltam do quadro XXV, onde figura o crescimento percentual dos operários de vários níveis de qualificação e dos técnicos e engenheiros, para os principais ramos industriais ${ }^{13}$ do Estado de São Paulo. Comparando-se inicialmente o crescimento de todo o operariado com o dos técnicos e engenheiros, verificamos os valores consideravelmente mais elevados para esses últimos. Para todos os ramos do Estado, enquanto os operários em conjunto crescem mais de 50 por cento (multiplicam-se por uma vez e meia), os técnicos e engenheiros praticamente triplicam. Esse descompasso, como se pode ver, é quase sempre maior para as indústrias de bens de produção, que são os ramos que mais crescem no período.

Entre as várias categorias do operariado, a que mais aumenta é a dos semiqualificados: para o total dos ramos, crescem 83 por cento, enquanto os braçais aumentam de 64 por cento e os qualificados e mestres, quase não aumentam. Essa tendência se verifica no geral em todos os ramos.

Mais significativo que os níveis elevados de burocratização (entendido sempre como extensão de organização onde rotinas racionais e impessoais, numa estrutura hierarquizada, prevalecem) atingidos pelas indústrias do Centro-sul, particularmente pelas paulistas, é a concentração nessa área de empresas racionalizadas. Nela numerosas grandes organizações industriais passam a dominar a paisagem econômica e pode-se mesmo falar na burocratização da sociedade. Antes porém de aludir às implicações desse fato, tratemos brevemente do processo no setor público.

\footnotetext{
${ }^{13}$ Os ramos que tinham pessoal ocupado em 1963 superior a cinqüenta mil. Separamos esses ramos no quadro em dois grupos: os de bens de consumo (as indústrias têxteis, de alimentação e de vestuário são, não custa lembrar, as mais antigas do país, e aquelas onde o grau de obsoletismo é dos mais acentuados) e os de bens de produção (as indústrias mecânicas, metalúrgicas e de materia elétrico, as de transporte, e as químicas e farmacêuticas). Não que tenham aquele caráter todas essas últimas indústrias. Quer-se apenas indicar que nesses ramos se situam, em apreciável medida, as de bens de produção e, o que é mais importante para o assunto que ora nos prende a atenção, entre elas se encontram as mais modernas que se desenvolveram nos últimos anos no Brasil.
}

Quadro XXV

Crescimento percentual em $1963(1951=100)$ do operariado (conforme níveis de qualificação) e dos técnicos e engenheiros para os principais ramos industriais,

Estado de São Paulo

\begin{tabular}{|c|c|c|c|c|c|c|c|c|}
\hline \multirow{2}{*}{ RAMO INDUSTRLAL } & \multicolumn{2}{|c|}{$\begin{array}{l}\text { Totals ABsolutos } \\
\text { (milhares) }\end{array}$} & \multirow{2}{*}{$\begin{array}{c}\text { CRESCI- } \\
\text { MENTO } \\
\% \\
19.51= \\
100\end{array}$} & \multicolumn{5}{|c|}{ 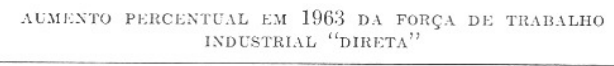 } \\
\hline & 1951 & 1963 & & $\begin{array}{c}\text { Brasais } \\
\text { (1) }\end{array}$ & $\begin{array}{l}\text { Semiqua- } \\
\text { lificados } \\
(2)\end{array}$ & $\begin{array}{l}\text { Qualificados } \\
e \text { mestres } \\
\text { (3) }\end{array}$ & $\begin{array}{c}\text { Operariado } \\
\text { total } \\
(1+2+3)\end{array}$ & $\begin{array}{l}\text { Técnicose } \\
\text { engenheiros }\end{array}$ \\
\hline \multirow{2}{*}{\multicolumn{9}{|c|}{$\begin{array}{l}\text { Bens de producãoo(*) } \\
\text { MIeccinicas, meta- } \\
\text { lúrgicas e material } \\
\text { elétrico. }\end{array}$}} \\
\hline & & & 294 & 441 & 318 & 222 & 293 & 524 \\
\hline Transporte........ & 37 & 58 & 159 & 122 & 209 & 175 & 158 & 727 \\
\hline $\begin{array}{l}\text { Químicas e farma- } \\
\text { cêuticas........ }\end{array}$ & 28 & 54 & 190 & 281 & 163 & 266 & 188 & $25 \%$ \\
\hline Bens de consumo & & & & & & & & \\
\hline Fiação e tecelagem & 168 & 180 & 107 & 138 & 171 & 19 & 107 & 197 \\
\hline Alimentaşāo..... & 68 & 70 & 103 & 97 & 102 & 122 & 103 & 160 \\
\hline Vestuário......... & 48 & 62 & 128 & 229 & 217 & 75 & 128 & 183 \\
\hline $\left.\operatorname{TotaL}{ }^{* *}\right) \ldots$ & 6.57 & 1.026 & 156 & 164 & 183 & 106 & 156 & 299 \\
\hline
\end{tabular}

(*) Ver nota 13 , no texto.

(**) Todos os ramos, inclusive os que não constam do quadro.

Fonte: SENAI (adaptado de quadros de PEREIRA, 1965, págs. 245 e 246)

Basicamente o aumento da burocracia governamental responde à maneira pela qual se deu o desenvolvimento brasileiro, especialmente nos anos pós-guerra, com o crescimento dos investimentos públicos, dos gastos com previdência social, serviços de saúde e educação, etc. ${ }^{14}$. Reflete-se o

\footnotetext{
${ }^{14}$ Eis o que escrevem sobre o assunto os autores do Plano Trienal: "Em face das modificações estruturais ocorridas na economia com aumento rápido da urbanização e crescimento das indústrias pesadas, era perfeitamente natural que os investimentos infra-estruturais aumentassem em termos relativos, exigindo-se maior esforço do Governo, tanto na prestação de serviços como no processo de formação de capital e maior participação do setor público no dispêndio total, à semelhança do que ocorreu em todos os países em rápida industrialização (...) E no período 1947-1960, elevou-se aquela participação em decorrência sobretudo do aumento dos investimentos públicos, cuja participação no dispêndio total mais que duplica entre os extremos do período, enquanto o consumo público aumenta menos de $40 \%$. Ademais, todo o aumento dos itens 'consumo público', 'transferências' e 'subsídios', ocorre, praticamente, entre 1947 e 1956, ano em que a soma desses itens alcança 20,6\%, para
} 
incremento crescente do setor público na elevação, por exemplo, do número de servidores federais: de 131.628 em 1938, para 145.991 em 1943, alcançando em 1958 246.582, elevação em termos relativos superior à população ${ }^{15}$.

O modo concreto pelo qual se está dando o crescimento da máquina estatal merece exame mais detido, mormente no referente à diferenciação do fenômeno entre a parte dinâmica do país, no Centro-sul, e as regiões menos desenvolvidas, como seja o Nordeste. Estudos recentes de Vieira da Cunha sobre o assunto fornecem-nos os dados necessários ${ }^{16}$.

No quadro XXVI, que extraímos de seu trabalho, nota-se o seguinte sobre o crescimento da burocracia nas três regiões (Nordeste, Leste e Sul) mais povoadas do país. Em todas elas o aumento relativo à população, da burocracia civil e militar, entre 1920 e 1940, é o mesmo: dobra de 3 para 6 funcionários por 1.000 habitantes, no Nordeste, e de 7 a 14 no Leste e no Sul. Para que isso ocorresse, como o crescimento demográfico foi diverso, foi preciso um incremento muito mais forte na burocracia no Sul (onde ela mais que triplicou), que no Leste (onde se multiplicou por dois e meio) e ainda mais que no Nordeste (onde o aumento foi de apenas 128 por cento).

Os comentários de Vieira da Cunha sobre o crescimento da máquina burocrática do Governo, de 1920 a 1940, colocam-no justamente na perspectiva que nos interessa, a da mudança da estrutura do poder.

Na região Sul o impacto do crescimento demo gráfico é bastante forte para obrigar o Estado a multiplicar-se em serviços e pessoal (...) Assim, o processo de rompimento com a organização dos clãs

declinar, em 1960, até 20,2\%. A partir de 1956, a participação do setor público no dispêndio tota eleva-se quase exclusivamente por força do aumento dos investimentos". Plano Trienal, p.39 (ver também o quadro na mesma página).

${ }^{15}$ VIEIRA DA CUNHA, 1963, p.129. O aumento do funcionalismo federal entre 1938 e 1958 foi de 87 por cento; o da população de 1940 a 1960 foi de 72 por cento. Utilizamo-nos de dados sobre os servidores civis da União, ao invés de outros para toda a burocracia civil, por não serem comparáveis a esse respeito, como indicaremos adiante (p.106), as informações dos censos de 1940 e 1950.

${ }^{16}$ Ibidem. particularmente os capítulos "A burocracia civil e militar, de 1920 a 1940" e "A burocracia civil, de 1940 a 1950" (p.110 a 145) políticos rurais é intensificado na região Sul. Na região Leste, o patriarcalismo político absorve o Estado, sustentando-se um equilíbrio, no fundo contraditório, entre o desenvolvimento do Estado e a manutenção dos grupos políticos rurais. Este equilíbrio sustenta-se graças ao processo de sujeição do Estado a estes grupos, em termos patriarcais e, mais do que isso, de ineficiência dos serviços públicos, compreendidos quase exclusivamente em termos de manutenção de uma clientela política. No Nordeste, o patriarcalismo estadual mostra-se menos desenvolvido. Os grupos políticos locais preferem sustentar a clientela de dependentes, desinteressando-se mais do que na região Leste pelo domínio sobre a maquinaria política central, ainda que em termos de oportunidades para favoritismos políticos ${ }^{17}$.

É a passagem da organização oligárquica da República Velha para a recente estruturação do poder, que examinamos no capítulo 'anterior, o pano de fundo necessário à compreensão dessa expansão da burocracia, nas suas variadas modalidades. Os traços principais da nova organização do poder - o fortalecimento do poder central, a influência crescente das massas urbanas no processo político, e a sobrevivência do compromisso com o coronelismo nas áreas mais tradicionais do país - são fundamentais para entender-se o aumento maior ou menor dos serviços públicos e sobretudo o seu funcionamento, numa área e noutra do Brasil.

$\mathrm{Na}$ expansão da burocracia governamental no período mais recente continua a refletir-se a forma assumida pelo desenvolvimento, seja nos seus aspectos econômicos, seja nos políticos, diferenciando-se regionalmente.

Para o estudo da burocracia entre 1940 e 1950 encontra-se a dificuldade decorrente da falta de comparabilidade dos dados, principalmente por terem sido as atividades de previdência social e de assistência médico-hospitalar pública incluídas, em 1940, em “administração pública" e, em 1950, em "atividades sociais" ${ }^{18}$. Resulta

\footnotetext{
${ }^{17}$ Ibidem, p.117.

${ }^{18}$ Ver Giórgio MORTARA, 1956, p.112.
} 
desse fato a aparência de um declínio no número de pessoas cuja atividade principal é a administração pública.

\section{Quadro XXVI}

Crescimento da burocracia civil e militar (*), entre 1920 e 1940, e número de funcionários por 1.000 habitantes nas duas datas, por regiões

\begin{tabular}{|c|c|c|c|c|c|}
\hline \multirow{2}{*}{$R E: G \perp \tilde{A} O$} & \multicolumn{2}{|c|}{$\begin{array}{l}\text { BUROCRACIA CIVIL } \\
\text { E MILITAR }\end{array}$} & \multirow{2}{*}{$\begin{array}{l}\text { PORCEN- } \\
\text { TAGEM } \\
\text { DE AU- } \\
\text { MENTO } \\
\text { NO } \\
\text { PERIODO }\end{array}$} & \multicolumn{2}{|c|}{$\begin{array}{l}\text { NÉMERO DE FUN- } \\
\text { CIONÁRIOS POR } \\
1.000 \text { HABITINTES }\end{array}$} \\
\hline & 1920 & $\begin{array}{c}\text { A umento } \\
\text { de } 1920 \\
\text { a } 1940\end{array}$ & & 1920 & 1940 \\
\hline Norte...... & 11.123 & 5.334 & 47,0 & 8 & 11 \\
\hline Nordeste... . & 2.5 .629 & $32.90 \%$ & 128,1 & 3 & 6 \\
\hline Leste........ & 89.572 & 126.708 & 141,4 & 7 & 14 \\
\hline Sul..... & 54.969 & 123.330 & 224,3 & 7 & 14 \\
\hline Centro-Oeste... & 4.833 & 8.535 & 176,6 & 7 & 10 \\
\hline BrasiL......... & 186.126 & 296.812 & 159,5 & 6 & 12 \\
\hline
\end{tabular}

(*) Número de indivíduos com atividade principal em administração pública, legislativo, inclusive defesa nacional e segurança pública.

Fonte: Censos de 1920 e 1940 (apud VIEIRA DA CUNHA, 1963. págs. 113 e 116).

Como foram sempre os mesmos setores do serviço público excluídos de cada Estado, podemos comparar, em cada ano, os dados de Estado a Estado. A redução a números-índices de taxas de funcionários em relação à população total ou a setores dela, revelam diferenças importantes no crescimento da burocracia de uma região para outra. É o que os dados organizados no quadro XXVII permite-nos perceber. Figuram nele taxas da burocracia civil (o número de funcionários por mil pessoas da população total, da população ativa e da população do setor terciário) e númerosíndices para estas taxas, quando se faz a taxa para o Nordeste, em cada caso, igual a cem.
Quadro XXVII

Taxas da burocracia civil por 1.000 pessoas da população total, da população ativa e do setor terciário, e números-índices calculados com base nessas taxas, por região, 1940 e 1950

\begin{tabular}{|c|c|c|c|c|c|c|}
\hline \multirow{3}{*}{$\mathrm{REGI} \tilde{A} O$} & \multicolumn{6}{|c|}{ TAXa DA BUROCRACIA CIVIL POR 1.000 PESSOAS } \\
\hline & \multicolumn{3}{|c|}{1940} & \multicolumn{3}{|c|}{1950} \\
\hline & $\begin{array}{c}\text { da po- } \\
\text { pulação } \\
\text { total }\end{array}$ & $\begin{array}{l}\text { da po- } \\
\text { pulação } \\
\text { atwa }\end{array}$ & $\begin{array}{l}\text { do setor } \\
\text { terciário }\end{array}$ & $\begin{array}{c}\text { da po- } \\
\text { pulasáo } \\
\text { total }\end{array}$ & $\begin{array}{c}\text { da po- } \\
\text { pulaşão } \\
\text { ativa }\end{array}$ & $\begin{array}{l}\text { do setor } \\
\text { terciário }\end{array}$ \\
\hline Norte.... & 8 & 22 & 113 & 5 & 17 & 72 \\
\hline Nordeste....... & 4 & 10 & 97 & 3 & 9 . & 52 \\
\hline Leste.... & 8 & 20 & 118 & 6 & 18 & 62 \\
\hline Sul......... & 9 & 24 & 110 & 5 & 16 & 55 \\
\hline Centro-oeste.... & 4 & 13 & 100 & 3 & 11 & 74 \\
\hline Brisil... & 7 & 22 & 112 & 5 & 15 & 58 \\
\hline
\end{tabular}

NUTEROS-ÍNDICES

$($ Taxa para o Nordeste $=100)$

\begin{tabular}{l|l|l|l|l|l|l}
\hline Norte......... & 200 & 220 & 116 & 167 & 189 & 138 \\
Nordeste....... & 100 & 100 & 100 & 100 & 100 & 100 \\
Leste.......... & 200 & 200 & 122 & 200 & 200 & 119 \\
Sul........... & 22.5 & 240 & 113 & 167 & 178 & 106 \\
Centro-oeste ... & 100 & 130 & 103 & 100 & 122 & 142
\end{tabular}

Fonte: Censos de 1940 e 1950 (adaptação de quadro de VIEIRA DA CUNHA, 1963, p.134).

$\mathrm{Na}$ verdade podemos supor que, não fosse a omissão daqueles setores já indicados na categoria "administração pública" do censo de 1950, todas as regiões do Brasil acusariam crescimento dos serviços públicos durante aquela década. Tal crescimento, porém, em termos relativos à população total, foi menor na região Sul do que no Nordeste. De fato, fazendo-se igual a 100 a taxa da burocracia nessa região, obtém-se o índice 225 para o Sul em 1940, enquanto em 1950 esse índice, ainda com o Nordeste igual a 100, 
atinge apenas 167. Para os dados relativos à população ativa, nota-se queda ainda mais acentuada. Para 100 no Nordeste, há o decréscimo do índice para o Sul de 240 para 178, entre 1940 e 1950 . Em relação à população terciária, porém, o crescimento da burocracia civil no Nordeste fez-se quase no mesmo ritmo que no Sul (o nosso índice para essa região passa de 113 para 106 naquele período). Tais fatos decorrem do crescimento relativamente mais intenso do setor terciário nas regiões menos desenvolvidas, isto é, da sua concentração urbana sem industrialização, que foi caracterizada na primeira parte deste trabalho.

Em suma, o aumento do funcionalismo constitui no Sul e no Nordeste fenômenos distintos. Nessa última região ele cresce em relação à população total mais depressa que no Sul, no mesmo passo em que se ampliam as ocupações terciárias, isto é, como parte do processo geral de "inchação" das cidades na região; no Sul, responde, pelo menos em boa medida, a aumento real dos serviços públicos. É o que observa o autor em que nos estamos apoiando para esse tratamento da expansão da burocracia estatal:

[No Nordeste a] expansão da burocracia responde à mesma pressão que caracteriza aí a ampliação do setor de atividades terciárias de modo mais ou menos divorciado das reais exigências do desenvolvimento econômico, assumindo mesmo feições parasitárias ou de desperdício que, em relação às atividades econômicas, se manifestam sob a forma do pequeno comércio ambulante, a complicação inútil e dispendiosa dos pequenos agentes intermediários e que na burocracia se apresenta no apego ao empreguismo público, na disciplina frouxa de trabalhos dos serviços públicos, etc. Já na região Sul, a expansão paralela da burocracia com o setor de atividades terciárias responde à mais eficiente participação do setor público no processo econômico, aliado a uma concepção ou necessidade da ajuda prestada pelo Estado aos particulares ${ }^{19}$.

Analisemos um pouco mais a burocracia nas áreas mais atrasadas do país. Um artigo dos editores da revista Cadernos do Nosso Tempo, há

\footnotetext{
${ }^{19}$ VIEIRA DA CUNHA, 1963, págs. 143-144.
}

alguns anos atrás, assim caracterizava o que chamava de "Estado Cartorial" no Brasil. Nele, afirmavam:

(...) os órgãos e as funções públicas, a despeito de sua funcionalidade aparente, de fato não se [destinam], primariamente, à prestação de serviço público, e sim à realização da política de clientela (...) à administração de proteção e de favores aos clientes de cada grupo oligárquico e à concessão de emprego à classe média ${ }^{20}$.

Duas observações precisam ser feitas: primeiro, embora ainda seja de grande generalidade, a validade dessa formulação tende a restringir-se às áreas extensas, onde prevalece a organização patrimonialista; em segundo lugar, mesmo nessas, trata-se menos de Estado que precisa assistir dos modos tradicionais a dependentes e desempregados, do que da sustentação por ele de uma estrutura social e política ${ }^{21}$. Devemos lembrar-nos que os grupos políticos, locais e regionais, de cunho tradicional, entrosam-se, em escala nacional, numa mesma estrutura de poder.

Evidencia-se essa situação, com particular clareza, no papel de muitos órgãos federais no Nordeste. Louvemo-nos novamente no estudo feito da região por Hirschman ${ }^{22}$. Ele nos mostra como a ação federal, com as obras contra a seca e, no Vale do' São Francisco, com as da comissão criada para o seu desenvolvimento, tem por função a sustentação do poder dos clãs políticos locais e regionais, aliados do Governo Central. Alguns casos bastarão.

\section{Sobre os açudes escreve:}

Desde o começo, pretendia-se que os grandes açudes fossem "baluartes" de resistência à seca no Sertão mesmo, tornando desnecessárias as migrações esgotadoras e humilhantes dos sertanejos para o litoral e poupando às cidades o contato com os flagelados miseráveis e por vezes amotinados (p.27).

\footnotetext{
20 "Para uma política nacional de desenvolvimento", 1956, P.136.

${ }^{21}$ Cf. VIEIRA DA CUNHA, 1960, págs. 19.5-206.

${ }^{22}$ HIRSCHMAN,p.63, págs. 11-91.
} 
Por outro lado, como já vimos (p.68), o aproveitamento dos atingidos pela seca em "frentes de trabalho", na construção de açudes e estradas, prende a população à região e mantém nela mão-de-obra abundante e barata $^{23}$.

Sobre a Comissão do Vale do São Francisco, observa o mesmo autor:

No órgão, logo se percebeu que a regularização do Rio necessitaria, antes de mais nada, forte investimento em uma ou duas represas rio acima, mas as forças que se haviam apoderado da Comissão estavam muito mais interessadas numa série de pequenos projetos que dariam oportunidade de recompensar amigos e influenciar pessoas (...).

E nota ainda que:

(...) era um segredo de polichinelo ser o principal poder sobre o órgão, desde o começo, um influente deputado federal das zonas rurais do Estado da Bahia, Manuel Novais, cujo moto "política é favor" simboliza a tradição "clientelística" da política brasileira (p.53).

Trata-se de clara patrimonialização da administração federal. Não seria outra a conclusão se examinássemos a atuação do DNOCS ${ }^{24}$.

\footnotetext{
${ }^{23}$ A oposição dos nordestinos à emigração é tradicional. Veja-se, em HIRSCHMAN, a referência à posição de José Américo de ALMEIDA, no Inicio da década dos anos 30 e à tentativa, em data recente, do senador Argemiro Figueiredo, de através de emenda proibir à SUDENE de ter atividades que resultem em movimentos de nordestinos de um Estado para outro (idem, págs. 37 e 87).

${ }^{24}$ Leia-se a secção "Seca, fome e voto" do artigo de Abelardo MONTENEGRO, referente às eleições no Ceará em 1958, e o trecho que transcreve de Jader de CARVALHO, sobre as maneiras de atuação do DNOCS nas eleições: "Primeira, caracterizada largamente (...) pelos horrores da discriminação partidária. Segunda, marcada pela ação direta dos engenheiros sobre os cassacos e da guarda pretoriana do DNOCS, especialmente criada para o amedrontamento dos eleitores sertanejos, dentro ou fora dos serviços. Terceira, compreendendo as 42 horas que antecederam a eleição e assinalada pelos fatos seguintes: a) utilização de 300 caminhões do DNOCS para o transporte de eleitores, na vizinhança das obras federais; b) compra dos cabos eleitorais; c) compra direta do eleitor mediante dinheiro e roupa nova; d) ameaças dos engenheiros: quem não "atasse a favor seria despedido dos serviços; e) venalidade de alguns chefes". MONTENEGRO, 1960, págs. 43-46 (a citação é dessa última página)
}

Alguns órgãos federais, estabelecidos no período mais recente, como o Banco do Nordeste do Brasil, em 1952 e, em 1959, a SUDENE, permaneceram em relativa independência das oligarquias locais ${ }^{25}$. $\mathrm{O}$ exame desses casos revela o funcionamento da nova estrutura do poder que vigora no país. Assim destaca-se no relato de Hirschman, da batalha pela SUDENE e pela aprovação do seu Primeiro Plano Diretor, o papel da divisão do poder político (lutas de grupos estaduais entre si e contra o Governo Federal) e o apoio recebido de organizações e da "opinião pública" dos Estados do Sul e de cidades nordestinas ${ }^{26}$.

Em síntese, o crescimento do setor público suscitado pelo desenvolvimento econômico, devido ao caráter desse desenvolvimento, fazse por formas diversas nas partes mais desenvolvidas e nas mais atrasadas do Brasil. No Sul, embora o clientelismo não deixe de comparecer, multiplicam-se na realidade os serviços e empreendimentos públicos para a

${ }^{25}$ Sobre o Banco, HIRSCHMAN escreve o seguinte: "the BND did not become the fief of one political group (...) the number of purely political appointees appears to have been quite limited", e sobre a SUDENE, considera que a inclusão dos governadores dos nove Estados nordestinos no seu Conselho Diretor tornava improvável a transformação do órgão num mero apêndice de uma máquina política, notando que esses governadores "were bound to be representative of widely different power groups and parties" (HIRSCHMAN, 1963, págs. 65 e 83).

${ }^{26}$ Ver especialmente os trechos "The Drought, DNOCS, and the 1958 Elections", "The Battle' for SUDENE" e "SUDENE in Action", onde o autor se refere à vitória em 1958 de candidatos oposicionistas ao Governo Federal para a governança dos Estados da Bahia e Pernambuco, ao segundo Encontro dos Bispos do Nordeste, em meados de 1959 em Natal, que endossou com entusiasmo a Operação Nordeste (essa ação dos bispos, lembra o autor, possivelmente resultou da preocupação com a difusão das ligas camponesas), à campanha pelos jornais do Rio contra o DNOCS e os "industriais da seca" e a favor das ligas e da SUDENE, e ao apoio político dado ao órgão por parlamentares representantes do Sul e pelas mais diversas organizações e associações econômicas, sindicais e estudantis (grupos urbanos). Sobre, por exemplo, a emenda ao Plano Diretor da SUDENE, que anulava a sua eficácia e foi aceita pelo Senado, escreve HIRSCHMAN "SUDENE was not only defended, as in 1959, by the most respected Rio and São Paulo daily papers, but was now able to marshal considerable 'grass-roots' support in the North-east. Protests against the Senate's action and petitions to the House to restore the original version of the law were sent by a wide variety of groups - Governors, Chamber of Commerce, Small Farms Federation - and the movement was climaxed on December 6, 1961 by one-hour strike of all commercial and industrial establishments and a mass meeting in Recife" HIRSCHMAN, 1963, págs. 68-72 e 78-91 (a citação é da p.88). 
população ${ }^{27}$, enquanto que no Nordeste e Leste até órgãos federais ficam a serviço de oligarquias regionais, num processo de quase privatização de recursos públicos. Na verdade, no Sul "clientelismo" - termo vago que abrange fenômenos diferenciados - somente pode ser compreendido em função da política de massa, em ascensão em todo o país, mas sobretudo nas regiões mais adiantadas e urbanizadas do Sul. Aí, políticos reivindicam cada vez mais, dos governos estadual e federal, obras (uma escola, estrada ou ponte) para a "sua zona" ou o "seu município". Nas áreas imersas no patrimonialismo tradicional, de outro lado, não há ainda completa distinção entre o "público" e o "privado". Num caso, o apoio político a troco de "cargos" e de "obras" responde ao novo populismo - é talvez novo tipo de patrimonialismo que se estabelece na base de camadas médias e baixas urbanas; no outro, trata-se da sobrevivência do coronelismo, ao qual agora se ajustam até os órgãos federais locais, cada vez mais numerosos e significativos, da mesma maneira como antes o faziam as autoridades estaduais $^{28}$. São ainda as antigas oligarquias regionais, participantes hoje,

${ }^{27} \mathrm{O}$ estudo de Oracy NOGUEIRA sobre o desenvolvimento de São Paulo colige dados pertinentes à expansão de serviços públicos neste Estado, particularmente no que se refere à índices educacionais (ver, por exemplo, o quadro XXX, à p.183, sobre a criação de ginásios, colégios e escolas normais estaduais, a quase totalidade dos quais o foi após 1940, intensificando-se fortemente a constituição dessa rede escolar depois de 1950) e a índices demografo-sanitários (NOGUEIRA, 1904). Não há dúvida que, como de resto toda a administração pública brasileira, a do Sul também conserva traços da organização patrimonialista. Isso foi salientado por WILLEMS em artigo escrito em 1945 (WILLEMS, 1945). O que se afirma, porém, é que no Sul as mudanças no modo de funcionamento da máquina estatal já são sensíveis e relativamente rápidas.

${ }^{28}$ Parece-nos, pois, errôneo confundir ambos fenômenos numa mesma concepção de um "Estado Cartorial", como o faz Hélio JAGUARIBE, ao escrever, por exemplo, sobre os anos 30: "O desemprego da classe média (...) foi resolvido pela hipertrofia do funcionalismo federal, civil e militar, mediante uma reforma da administração que, sob o pretexto - sincero do ponto de vista dos seus autores - de modernizar a máquina administrativa e as Forças Armadas, na verdade,. as ampliaram extraordinariamente. Acumulou-se a administração de tarefas de caráter puramente formal, para o atendimento das quais múltiplos órgãos e inúmeros funcionários se fazem mister, com o Único resultado prático, no entanto, de a máquina estatal trabalhar para se manter e se controlar a si mesma. Era o Estado Cartorial, que existe para atender à política de clientela, em que o apoio político se obtém em contrapartida do emprego público. Esse Estado Cartorial resistira à derrocada do Estado Novo, em 1945, porque subsistirá, ao se restabelecer a democracia eleitoral, a demanda clientelística do emprego público" (JAGUARIBE, 1962, p.175). Colocam-se fatos diversos dentro da concepção talvez como sócios menores, de estrutura política complexa, de âmbito nacional.

Crescem as organizações públicas e privadas e ocorre verdadeira burocratização da sociedade nas regiões urbanizadas do Centro-sul e do $\mathrm{Sul}^{29}$. Nessas regiões aquele processo abrange populações urbanas e rurais. As suas conseqüências não se acham pesquisadas no Brasil. A julgar, porém, pelos estudos de outros países, esses efeitos, conjugados com os das comunicações de massa ${ }^{30}$, atingem os mais diversos fenômenos, desde o plano da organização da personalidade (desenvolvendo a orientação "pelos outros"), até o comportamento político (de massa e não de classe) e o plano ideológico (a ideologia das "relações humanas") ${ }^{31}$. Possivelmente tais mudanças também ocorrem, de modo atenuado, no mundo urbano do Nordeste. Os dados utilizados na análise dos serviços públicos não nos permitem diferençar, nessa região, a zona urbana da rural. Nesta última zona, entretanto, o aumento do funcionalismo do Estado faz-se claramente, de modo diverso. Trata-se menos de burocratização do que de crescimento da estrutura patrimonialista, entrosada agora numa organização política nacional. Aprofunda-se assim a diferenciação entre a área urbanizada e a não-urbanizada do Nordeste. Enquanto naquela se aceleram mudanças no todo similares às das partes adiantadas do país, nessa última consolida-se o patrimonialismo, agora também amparado pelo Governo Central. Estes problemas serão retomados adiante, particularmente no capítulo VII. É preciso agora passar aos outros processos gerais secularização e individualização - objeto deste capítulo.

de clientelismo, sem se perceber o funcionamento novo da máquina do Estado, sob as pressões do desenvolvimento e das massas urbanas. Para JAGUARIBE, parece, o novo papel do Estado só se inicia na década dos anos 50 (ver, na mesma obra, todo o trecho "A decolagem do desenvolvimento", págs. 169-183)

${ }^{29}$ Voltamos aqui a utilizar a nossa divisão de áreas do país (ver, acima, o capítulo IV) abandonando a do censo (onde Sul abrange os Estados de São Paulo para o sul), cujos dados estávamos usando.

${ }^{30}$ Ver, adiante, págs. 176 e segs.

${ }^{31}$ Cf., entre outros, RIESSMAN, 1950; KORNHAUSER, 1959; e BENDIX, 1956, capítulo V. 


\section{Secularização e individualização}

"O Brasil pode ser pensado como uma "cultura católica", escreve o antropólogo Charles Wagley - "tão fundas são as raízes do catolicismo no estilo de vida nacional" 32 . Este catolicismo em tempos passados, mormente na colônia, ensina-nos Gilberto Freyre, era instituição intimamente ligada à família patriarcal ${ }^{33}$. Em nossa cultura rústica, entre as camadas mais humildes da população rural - a lição agora é de Antônio Candido - as festas religiosas do catolicismo do caipira constituíam parte integrante da sociabilidade de bairro, ajustada a uma frugal economia de autoconsumo com a penetração do mercado e conseqüente individualização da atividade econômica, tais manifestações religiosas desintegram-se ${ }^{34}$. O catolicismo tradicional prende-se pois à organização comunal e à família patriarcal. Com a desintegração ou enfraquecimento dessas estruturas nas áreas urbanas e urbanizadas, atenuam-se as tradições católicas. Secularização e individualização ${ }^{35}$, nas suas formas concretas, entrelaçam-se. Entendido

\footnotetext{
${ }_{33}^{32}$ Charles WAGLEY, 1963, p.232.

33 "A casa-grande, completada pela senzala, representa todo um sistema econômico, social e político: [inclusive] de religião (o catolicismo de família, com capelão subordinado ao pater familias; culto dos mortos, etc.) (...) O costume de se enterrarem os mortos dentro de casa, - na capela, que era uma puxada da casa - é bem característico do espírito patriarcal de coesão da família. Os mortos continuavam sob o mesmo teto que os vivos. Entre os santos e as flores devotas. Santos e mortos eram afinal parte da família (...) Nunca deixou de haver no patriarcalismo brasileiro (...) perfeita intimidade com os santos." FREYRE, 8. a edição, 1954, 1. ${ }^{\circ}$ vol., págs. 24, 28-29.

${ }^{34}$ CANDIDO, 1964.

${ }^{35}$ CANDIDO, 1964.
O sentido que emprestamos a esses conceitos é o de REDFIELD. Esse autor, em sua pesquisa no Iucatan, conclui não serem aplicáveis aos seus resultados os conceitos de sagrado e profano de DURKHEIM, para quem se distinguem os dois domínios pela absoluta diferenciação entre eles existente, pela impossibilidade mesmo de um se par em contato com o outro e, portanto, pela presença de ritos de transição, purificação e interdição. Para as comunidades mexicanas, outras seriam as concepções mais adequadas, a saber, que “(...) um objeto é sagrado na medida em que há relutância, apoiada emocionalmente, em apreciar a coisa sob o ponto de vista racional ou prático. Os objetos seculares tratam-se sem relutância, de maneira prática ou mesmo crítica”. Secularização passa a ser assim aspecto da racionalização do comportamento. Por outro lado, para o antropólogo americano, "uma sociedade é individualista na medida em que o comportamento socialmente aprovado de qualquer de seus membros não envolve a família, o clã, a vizinhança, a aldeia ou outro grupo primário". Noutra parte do livro, esse autor reconhece que "o foco [da crescente
}

esse fato básico, examinemos separadamente os dois processos, em alguns de seus aspectos.

Os estudiosos do Brasil são concordes em notar profunda secularização da sociedade ${ }^{36}$. Não há todavia trabalho sistemático sobre o processo e até os que versam sobre religião e assuntos pertinentes são poucos ${ }^{37}$. O que há, permite-nos esclarecer alguns aspectos concretos do fenômeno que nos interessa.

A par de crescente indiferença religiosa na área urbanizada do país, exibida pelas alterações de atitudes e de comportamento nas várias esferas da vida ${ }^{38}$, certas mudanças no catolicismo merecem, do mesmo modo como

individualização] reside no enfraquecimento da organização familiar”. REDFIELD, 1949, págs. 196, 361, 363-364.

${ }^{36}$ Para COSTA PINTO, este fenômeno "seems to be the deepest alteration taking place at the root of the social stratification process which Brazilian society is undergoing". Numa formulação em que se confundem secularização e individualização, tão unidos são no caso brasileiro, ele afirma: "the classic mechanisms of social integration, such as the patriarchal family, or the almost official catholic classic mechanisms of social integration, such as the patriarchal family, or the almost official catholic
religion, witness the loosening of their control over individual behavior, as a result of the development of a new type of contractual relations that are characteristic of these mass societies". COSTA PINTO, 1956, p.62.

${ }^{37}$ Os mais numerosos são os dos cultos afro-brasileiros no Brasil, principalmente na Bahia e no Nordeste, os menos interessantes para o nosso tema. Ver nesse campo BASTIDE, 1960. Entre os livros e artigos mais importantes sobre o protestantismo, os movimentos messiânicos e o espiritismo das suas várias modalidades estão: WILLEMS, 1955 b e 1966; Pereira de QUEIROZ, 1965; e C. CAMARGO, 1961.

${ }^{38}$ Note-se que parte da secularização em processo é justamente destacar-se, das outras áreas da vida, a religiosa. Numa pesquisa de valores e atitudes feita entre grupos de empresários industriais, operários qualificados e favelados, no Rio de Janeiro, procurou-se verificar a existência de diferenças entre os grupos quanto a atitudes religiosas e ao secularismo, e a conexão dessas com valores ligados ao desenvolvimento. Os resultados foram em grande parte inconclusivos. Entre os que não o foram, os seguintes são importantes para o nosso tema: 37 por cento dos empresários industriais e 21 e 25 por cento, respectivamente, dos operários e favelados responderam não praticar nenhuma religião. (A diferença entre o primeiro grupo e os outros dois é estatisticamente significativa; devemos observar ainda que os grupos diferem bastante em sua experiência urbana: 75 por cento dos empresários e apenas 43 e 35 por cento, respectivamente, dos operários e favelados nunca haviam vivido em zonas rurais ou semi-rurais.) Pouco mais do que um décimo dos três grupos praticavam religião diversa da católica. Quanto às relações entre atitudes referentes à religião e valores ligados ao desenvolvimento, elas se fazem em todos os casos na direção prevista (atitudes seculares ligadas à identificação 
o crescimento do kardecismo e da umbanda estudados por Cândido Procópio Camargo, e do protestantismo pentecostal, ser colocadas como "expressões do nosso relativo processo de racionalização e secularização", Todos esses fenômenos religiosos possuem "atributos de racionalização no sentido weberiano de orientação da vida por meio de valores éticos explícitos e coerentes - em contraposição à orientação pela tradição, fundada na permanência das formas habituais de agir e sancionada pela autoridade" ${ }^{39}$. Examinemo-los.

Pesquisas sobre o catolicismo e transformações nele efetuadas são praticamente inexistentes entre nós, Com base em observações gerais, algumas pesquisas em progresso e em estudos de comunidades, podemos caracterizar certos processos de mudança em curso no catolicismo no Brasil que são relevantes para a secularização da sociedade brasileira (sempre no sentido em que essa foi conceituada acima) ${ }^{40}$.

Um é o gradual declínio do catolicismo tradicional, o catolicismo das nossas populações rústicas, e a sua suplantação pela religião católica oficial, a da hierarquia eclesiástica, e também pelo protestantismo. Passa-se assim de comportamento religioso de caráter tradicional para outro que se situa em certa medida na área de conduta pensada e deliberada.

Nas zonas rurais brasileiras predomina um catolicismo de folk, desligado em grande parte das doutrinas e influência da Igreja. Para E. de

nacional), entretanto, as diferenças são pequenas e não são estatisticamente significativas. SILVERT e BONILLA, 1961, págs. 52-53, 166 e 183-185.

${ }^{39}$ C. CAMARGO, 1961, p.XIII. Os tipos de ação weberianos acham-se analisados em WEBER, 1944, vol. I.

${ }^{40}$ Duas pesquisas estão atualmente sendo realizadas neste campo. Uma, do Movimento de Educação de Base, pelo sociólogo inglês Emanuel de KADT e outra, dirigida pelos sociólogos Cândido Procópio CAMARGO, Oracy NOGUEIRA e Esdras Borges COSTA, sobre a influência do catolicismo e do protestantismo nas mudanças sociais no Rio Grande do Norte. Para a nossa caracterização das mudanças em curso no catolicismo, ajudaram-nos, além dos estudos de comunidade, os artigos de D. MUTCHLER (1965) e de E. de KADT (s/d, manuscrito). Agradecemos a este último autor ter-nos deixado consultar o manuscrito de seu artigo, ainda não publicado.
$\mathrm{Kadt}^{41}$ essa situação, além de decorrer de fatores históricos (o fato de os padres tradicionalmente ligarem-se à camada senhorial e a tolerância dos ritos africanos pela Casagrande, como política semideliberada para desviar a atenção dos escravos da sua condição de trabalho), reflete também a simples escassez de sacerdotes para a população espalhada em território imenso. As observações desse mesmo autor sobre o caráter do catolicismo dos rurícolas são iluminadoras. Nota serem centrais nas crenças e práticas religiosas rurais os conceitos "promessa", "proteção", "pedido", "milagre" e "mostrar respeito", e nota ainda que o devoto se liga aos santos por relações pessoais orientadas pelo princípio do ut des. Em seguida sublinha E. de Kadt que

(...) o caráter da relação entre o devoto e o santo é impressionantemente similar à [relação paternalista] cliente-patrão que prepondera na sociedade secular tradicional entre o camponês ou o trabalhador e o seu patrão ${ }^{42}$. Nesta também o patrão assume, como favor, a obrigação de olhar pelos interesses imediatos do lavrador, em troca de obrigações específicas e uma demonstração geral de respeito por parte deste. Nessa situação também o camponês espera um milagre secular sob a forma de favores muito especiais. Em suma, os conceitos-chaves do catolicismo de folk são quase idênticos aos que operam na esfera tradicional sócio-política.

As relações clientelísticas tradicionais e o catolicismo de folk se reforçam mutuamente. Não só porque, explica de Kadt,

(...) o patrão torna-se um santo substituto ou vice-versa (...) [mas também porque] canalizando-se os esforços dos camponeses para a contínua evocação do sobrenatural, reforçam-se em conseqüência as relações sociais, econômicas e políticas ${ }^{43}$.

Embora esse catolicismo ainda predomine nos bairros rurais e pequenos centros do interior do Brasil, não há dúvida de que está em lento declínio. Devido à ação de diversas influências - tais como a penetração de

\footnotetext{
${ }^{41}$ Op. cit.

${ }^{42}$ Sobre a relação paternalista tradicional, ver o capítulo VII

${ }^{43}$ Ibidem.
} 
produtos e modos de comportamento urbanos - secularizam-se ou desaparecem as festas tradicionais dos nossos rurícolas. Vejamos o que escreve Willems a esse respeito, em Cunha, no começo da década dos anos 40:

A tradição, relacionada com as festas, é sagrada, e com a secularização paulatina da vida, está-se perdendo o significado sacro, Esta perda exprime-se, por exemplo, na falta de respeito pelo caráter sacro das danças antigas e (...) ainda na comercialização das festas (...)

Na cidade, continua o mesmo autor, em contraste com a zona rural,

(...) os elementos tradicionais encontram, em escala crescente, competição de formas recreativas urbanas,

E ainda,

[a própria Igreja se tornou fator] de desintegração das festas tradicionais (...) numa tentativa de arrochar a disciplina eclesiástica dos fiéis, quis reduzir o que considerava o lado 'profano' das festas, fazendo reverter, ao mesmo tempo, os resultados financeiros em benefício exclusivo de obras que se relacionassem com a religião.

Por causa desse conflito, durante seis anos lá não se realizou a Festa do Divino ${ }^{44}$.

Contribua ou não a Igreja, a comercialização da economia age nesse como noutros casos no sentido da secularização. Ocorre lenta extensão do controle da Igreja (instituição com apoio nos centros urbanos) sobre as crenças e práticas religiosas das populações rurais mais afastadas. (Liga-se, também a esses processos, convém notar, a penetração paulatina durante todo este século do protestantismo nos meios rurais ${ }^{45}$.)

44 WILLEMS, 1961, págs. 83-89 e 173-178 (as citações são das págs. 177 e 178). Ver também Antônio CANDIDO, 1964, págs. 51-57 e 129-171.

${ }^{45}$ Após apontar a desvinculação das populações rurais em relação à Igreja Católica, WILLEMS observa num artigo: “(...) hampered by the chronic lack of priests, the Church has failed so far to build a defense mechanism which, it would seem, can only be created by regimentation and mass indoctrination. This means, of course, that the country has been wide open to missionary endeavors
Por outro lado, a própria vitalidade da Igreja urbana, parte da hierarquia mundial, situa-se no contexto da formação da sociedade urbanoindustrial. Muitos observadores já notaram predominar o catolicismo de Igreja (chamemo-lo assim para o distinguir da religião da maioria rural do país) entre as classes médias e altas urbanas, principalmente entre as mulheres. Desenvolve-se, o que nos importa salientar, com a urbanização e o crescimento daquelas camadas. O seu caráter, como E. de Kadt chama a atenção, associa-se ao esforço educacional eclesiástico, no nível secundário, que ganha corpo sobretudo nos últimos vinte anos ${ }^{46}$. O catolicismo da camada superior da população urbana diferencia-se, não resta dúvida, da religião da classe senhorial do passado, que se vinculava ao patriarcalismo da Casa-grande. No entanto, essa mudança dificilmente pode ser colocada como parte do processo de secularização, a não ser na medida que se verificasse ser ela relacionada (o que é passível de dúvida) a uma crescente indiferença religiosa masculina.

Por outro lado, certos movimentos recentes no catolicismo oficial, envolvendo tanto leigos quanto sacerdotes em ação, no plano secular, de natureza sócio-política e econômica, são relacionados à situação política brasileira e a fenômenos da Igreja em âmbito mundial. Pode ser lembrado o movimento leigo da Ação Católica, o dos Círculos Operários e os da juventude (Juventude Operária Católica, Juventude Estudantil Católica e

other than Catholic. Various Protestant denominations stepped into the picture to compete with the Catholic Church for the salvation of the souls which hitherto had not been taken care of. WILLEMS, 1955 b, p.322.

${ }^{46}$ Op. cit. Em 1959, 27 por cento de todos os estudantes secundários estavam matriculados em escolas da Igreja Católica (R. HAVINGHURST e R. MOREIRA. 1965, págs. 142-144, apud de KADT, s/d). São interessantes as observações, nesse mesmo artigo de E. de KADT, sobre a influência das escolas católicas: "Most of the male alumni of the schools seem to retain only their conservative social ideology. On the whole they become largely indifferent to religious matters (...) But middle class women reared in this tradition generally retain their devotional Catholicism. They are most active religiously, both as individuals and in organizations. A very substantial proportion of the urban clergy, and the vast majority of the male and female religious, are devoted to this form of Catholicism and give all their time and energy to keeping it alive". Nas camadas urbanas inferiores, onde são numerosas as pessoas de origem rural, o catolicismo de folk e o de Igreja fundem-se, formando um continuum entre a religião rural e a urbana das camadas superiores. 
Juventude Universitária Católica) e, mais recentemente, a ação patrocinada pela Igreja nos meios rurais, a formação de sindicatos rurais no Nordeste e, em todo o Brasil, o Movimento de Educação de Base. As raízes desse envolvimento em questões seculares acham-se, em parte, em correntes de pensamento e acontecimentos do mundo católico (por exemplo a influência de filósofos católicos como Maritain e Mounier, e das encíclicas de João XXIII) e, em parte, na atmosfera de "radicalização" das posições políticas no Brasil, sob efeito da política de massa.

Essa efervescência e consciência social de setores da Igreja e dos católicos (setores, por sinal, não muito amplos, mas vocais e influentes) são condições que nos parecem conducentes à racionalização do comportamento na própria esfera da religião. Fenômenos originados em parte lá fora, introduzem-se no Brasil na medida em que aqui encontram terreno propício, antes de tudo nas áreas urbanizadas, onde avançam outras religiões e onde as populações acham-se sujeitas aos influxos da civilização, pela difusão nesse meio do pensamento secular, das atitudes e valores modernos.

Esses processos têm lugar no catolicismo do Brasil, transformando-o, e bem mereciam pesquisas mais aprofundadas, a fim de se aquilatar sua extensão e seu significado para a transformação da sociedade global ${ }^{47}$. Limitamo-nos a colocar o problema.

Além do catolicismo, os principais fenômenos religiosos entre nós são as religiões afro-brasileiras, os movimentos messiânicos, o protestantismo, o kardecismo e a umbanda. São os três últimos - que aliás devem ser agrupados em dois - os que merecem exame mais detido ${ }^{48}$ : de um lado, os movimentos messiânicos que se localizam em certas áreas

\footnotetext{
${ }^{47}$ Ver, acima, a nota 40.
${ }^{48}$ É possível que também os cultos afro-brasileiros estejam sofrendo modificações debaixo da influência do desenvolvimento. Cândido Procópio CAMARGO o afirma: "Em cidades como Salvador e Recife, parte considerável da população adota as religiões de origem africana, que começam atualmente a sofrer forte influência do kardecismo, esboçando-se assim a formação do começam atualmente a sofrer forte influência do kardecismo, esboçando-se assim a formação do
continuum estudado [em São Paulo; continuum kardecismo-umbanda], que parece mais funcional, nas áreas urbanas, do que as tradicionais práticas sudanesas e banto". C. CAMARGO, 1961, p.92.
}

rurais e surgem amiúde a partir do século XIX; do outro, as seitas pentecostais, o kardecismo e a umbanda, fenômeno a se expandir no Brasil urbano, principalmente no período pós-guerra.

Sobre a possível conexão dos movimentos messiânicos com transformações globais da sociedade brasileira somos forçados a nos restringir a observações gerais. Resumamos os resultados dos estudos cuidadosos deles feitos por M. L Pereira de Queiroz, que compara em seu livro oito de tais movimentos ${ }^{49}$. As semelhanças que apresentam entre si são impressionantes.

Todos têm como fulcro um indivíduo que se acredita possuir atributos sobrenaturais e que vaticina catástrofes de que só se salvarão os seus adeptos; estes buscam ou desencantar um Reino ou fundar uma Cidade Santa, pondo para isto em prática os comportamentos aconselhados pelo líder. Os caracteres do Reino Messiânico também são do mesmo tipo geral: trata-se de um Reino Celeste que existirá nesse mundo, dotado de atributos maravilhosos, lugar onde não se adoece, onde não se precisa trabalhar, onde se é plenamente feliz, onde residem os santos. Os agrupamentos assim formados acabam quase sempre destruídos pelas forças da sociedade global (p.283).

Os componentes do movimento vão desde proprietários e sitiantes, até lavradores sem terra, de várias espécies, todos porém modestos, "as mais das vezes em nível de agricultura de subsistência" (p.284). Mais importante, todavia, é a observação de que aderem ao movimento em famílias, com todos os parentes e agregados, raramente como indivíduos isolados.

A autora identifica, na sua base, situação social de anomia, que pelo movimento é combatida. Em outras palavras, vê neles manifestamente "o intuito de reorganização e reordenação das relações sociais" (p.297), anseio a que responde por exemplo a fundação das Cidades Santas. Assim, na maioria dos movimentos messiânicos fortalecem-se os valores e padrões

${ }^{49}$ Pereira de QUEIROZ, 1965, principalmente págs. 194-308 e 318-328. 
tradicionais, as poucas inovações "[correndo] por conta das reformas necessárias a fim de que as antigas instituições sejam escoimadas de seus vícios" (p.301). Em todos eles "vemos conservar-se a hierarquia profana ao lado da nova hierarquia social inaugurada pelo líder" (p.302) e não raro mesmo, este esposa "as lutas e divisões políticas que já existiam na região, ao fundarem sua comunidade" (p.303). Aliás, conforme seja mais fraco ou mais forte o lado em que se alinha, é explicado o fracasso ou a permanência do movimento.

Por tudo isso, a autora vê os movimentos messiânicos não como luta de classes, encobertas ou não, ou como respostas à "transformação sóciocultural em processo", mas sim como "reações contra processos internos de anomia" (grifos nossos; págs. 318-319) ${ }^{50}$. Só o de Canudos, entre os que examina, foi para ela desencadeado pela intervenção da sociedade urbanizada sobre a sociedade rústica, isto é, por acontecimentos ligados à instalação da República. Repele, portanto, a tese de Nina Rodrigues e Euclides da Cunha de que tais movimentos se dão onde o Sertão se encontra com o Litoral e aquele reage às inovações da cultura estranha. Para contrariar essa tese, basta-lhe notar que nem sempre se opuseram os movimentos messiânicos ao progresso econômico, às vezes mesmo fomentaram-no.

Não são consideradas por Pereira de Queiroz outras formas de influência da sociedade urbano-industrial, que não sejam o contato cultural, tais como as que se processam através do mecanismo de mercado, com a mudança muitas vezes concomitante na área política. Para provar que nesses casos o estado de anomia deve-se a processos internos à sociedade sertaneja, não basta apenas ter mostrado que "nem sempre tradicionalismo quer dizer oposição ao progresso" (p.325). A concentração dos movimentos messiânicos no tempo e no espaço deve ser suficiente para sugerir-nos a

\footnotetext{
${ }^{50}$ Ao comentar diversos movimentos, afirma que "em todos eles, a anomia decorre de condições próprias ao tipo da sociedade rústica, tão peculiares que podemos até considerar constante nela certa desorganização. Esta pode agravar-se com. a atomização dos grupos familiares, dando lugar então ao movimento" (p.320). Não pára entretanto para analisar o porquê desta atomização.
}

atuação de processos sócio-culturais globais. Nota a autora que, a quase totalidade dos movimentos, ocorrem em:

$$
\begin{aligned}
& \text { duas áreas bem delimitadas [no Nordeste semi-árido e na região } \\
& \text { serrana de Santa Catarina] e com os mesmos característicos (...). Tem } \\
& \text { lugar em zona de criação e agricultura de subsistência, internamente } \\
& \text { homogêneas quanto ao estilo de vida, pois, como vimos, fazendeiros } \\
& \text { criadores e sitiantes levavam a mesma existência rude. Não } \\
& \text { encontramos movimentos nas áreas das grandes plantações de cana- } \\
& \text { de-açúcar e de algodão, e nem mesmo mais tarde nas fazendas de } \\
& \text { café (p.299). }
\end{aligned}
$$

Ocorrem quase todos dos meados do século passado para cá, entre as duas dezenas mencionadas pela autora. No Nordeste, concentram-se nas últimas décadas do século e no atual, após 1920. A economia e a sociedade da região semi-árida, como vimos ${ }^{51}$, sofrem profundas mudanças nesses períodos. Estariam tais modificações associadas ao processo de anomia? Não é difícil imaginá-lo, embora a tese necessite de investigação apropriada. Por outro lado, sabemos que àquelas mudanças, ligam-se outras de natureza política, parte por sua vez da transformação global do poder em âmbito nacional.

Já no fim do Império assistimos à formação, a partir dos clãs rurais, das oligarquias regionais, cujo poder, na República, é reconhecido abertamente. Esse processo dá-se de modos diversos em diferentes regiões. Durante a República Velha, por exemplo, Vieira da Cunha julga reconhecer nas regiões menos desenvolvidas, provocado pelo apoio do Governo Federal, um recuo

(...) na sua evolução política, fortalecendo o cunho local de suas oligarquias, fazendo ressurgir em alguns deles conflitos que revelam a volta a etapas anteriores de organização política, em que o banditismo se mostra como a nota nova nas lutas entre os clãs familiares rurais ${ }^{52}$.

\footnotetext{
${ }^{51}$ Ver, acima, p.68.

${ }^{52}$ VIEIRA DA CUNHA, 1963, p.20
} 
Até que ponto, tais condições - nas quais se sente o papel do poder central - são responsáveis pelos movimentos messiânicos? Algumas observações de Pereira de Queiroz, ao caracterizar o aparecimento da anomia nas áreas em estudos, são sugestivas.

As novas funções [da administração pública] eram em geral reinterpretadas e exercidas de acordo com a mentalidade local.

Por isso mesmo a administração da justiça tornava-se inoperante (...) muitos [dos magistrados] eram ligados aos chefes locais por laços de parentesco, que valiam mais do que as leis e os impediam de dar sentenças contra gente de sua família. Quando se criou uma polícia, para o Sertão, tornou-se novo fator de crime. Presos entre dois fogos - polícia e cangaço, - os roceiros se dividiram de acordo com as ofensas recebidas ou as alianças estabelecidas, apoiando os volantes ou auxiliando os bandidos. Este ambiente de insegurança se refletia na célula básica da sociedade, formada pelas pirâmides familiares (...) (p.294).

A nosso ver, não se pode atribuir esses fenômenos - movimentos religiosos cujos caracteres carismáticos e tradicionais se mesclam - a processos anômicos autônomos da sociedade sertaneja, sem antes se examinar os tipos de influência acima sugeridos. As conseqüências da transformação global da sociedade brasileira são sutis e multiformes. Fazem-se sentir através de processos econômicos, sociais e políticos.

Ao nos voltarmos agora para movimentos tais como as religiões mediúnicas e as denominações pentecostais, o seu caráter urbano e, por conseguinte, os seus vínculos com o desenvolvimento são bem mais claros,

É surpreendente o crescimento nas últimas décadas no Brasil urbano das seitas pentecostais do protestantismo (a Assembléia de Deus e a Congregação Cristã) e o das várias modalidades de espiritismo (o kardecismo e a umbanda, constituindo um continuum, como o demonstrou Cândido Procópio Camargo ${ }^{53}$ ).

\footnotetext{
${ }^{53}$ CAMARGO, 1961, págs. 13-15 e 83-92.
}

Willems informa-nos constituírem aquelas igrejas, em 1932, menos de dez por cento dos protestantes brasileiros (excluindo as comunidades alemãs). O movimento ganhou ímpeto depois da Segunda Guerra Mundial com a intensificação, lembremo-nos, das migrações internas no país, - e em 1958 contava um milhão e meio de membros, ou seja, mais da metade do total de protestantes. Quanto ao espiritismo as dificuldades de exatidão estatística são muitas, devido sobretudo à sua baixa institucionalização: grande proporção dos espíritas, especialmente dos "eventuais", surgem nas estatísticas como "católicos". Willems, após compulsar as várias fontes, estima-os juntamente com os daquelas seitas protestantes em "entre 4 e 5 milhões de pessoas, participantes do que talvez seja o maior movimento religioso de massa da história do Brasil, quiçá da América Latina" ${ }^{54}$.

O movimento é urbano. Para o espiritismo, pode-se verificar essa assertiva, com simples exame das estatísticas. As maiores quantidades de espíritas, em números absolutos e em porcentagem, encontram-se nos Estados mais urbanizados e que, em geral, acusam grande influxo de migrantes: em 1950, São Paulo, Rio de Janeiro, o então Distrito Federal e o Rio Grande do Sul, onde os adeptos do espiritismo somavam mais de 2,5 por cento da população e mais de cinqüenta mil pessoas. Numa análise mais detida para São Paulo, verificou Camargo que se distribuem, quase sem exceção, nas "áreas de grande desenvolvimento urbano do Estado". Estima ainda o mesmo autor, "sem temor de erro, em, pelo menos, 20 por cento da população do Estado", os participantes eventuais ${ }^{55}$.

Como os dados estatísticos não separam os protestantes segundo as várias denominações e como as que são mais antigas tiveram considerável penetração em áreas rurais e semi-rurais, é mais difícil utilizá-los para documentar o caráter urbano do movimento pentecostal. Conforme Willems, todavia, os convertidos dessas igrejas se fazem em alta proporção entre as camadas inferiores da população urbana, onde preponderam os migrantes vindos de cidades menores e das zonas rurais ${ }^{56}$. Chamemos pois

\footnotetext{
${ }^{54}$ WILLEMS. 1966, págs. 206-207 e 230-231.

${ }^{55}$ CAMARGO. 1961, págs. 89-92 e 173-176.

${ }^{56}$ WILLEMS, 1966, págs. 221-230.
} 
às mediúnicas e a essas denominações protestantes de religiões urbanas de massa.

Mostra-nos Camargo ${ }^{57}$ terem as religiões mediúnicas por função a "integração dos fiéis na sociedade urbana" (p.68). Pessoas recém-vindas da sociedade rústica brasileira, onde encontravam proteção e segurança, muitas vezes, em estruturas familiares tradicionais e em organizações patrimonialistas amplas, encontram-se nas grandes cidades em famílias pequenas, quando aí as têm, reduzidas o mais das vezes ao grupo conjugal, e economicamente fragmentadas. Escreve Camargo:

$\mathrm{Na}$ perspectiva institucional a grande mudança foi a diminuição do papel da família, não apenas como matriz formadora da personalidade, mas como grupo de amparo e proteção por toda a vida (p.67).

Nessas condições as religiões mediúnicas - às quais podemos acrescentar as denominações protestantes pentecostais constituem

(...) uma alternativa possível no processo de adaptação das personalidades às exigências da vida urbana (grifos no original; p.97).

Funções análogas, pois, na transição da sociedade patrimonialista para a urbano-industrial no Brasil, às preenchidas, entre outras instituições, pela legislação do trabalho, previdência social e partidos populistas - todos com forte cunho assistencial paternalista. Todos respondem à emergência da massa urbana ${ }^{58}$.

Quais as características das religiões de massa, que lhes tornam possível terem aquela função? Camargo destaca o fato de serem as

\footnotetext{
${ }^{57}$ Op. cit.

${ }^{58}$ Notemos, mais uma vez, que o fato de atenderem essas instituições político-administrativas ao aparecimento da massa urbana, torna-as fenômeno bem diverso da privatização do poder público que ocorre nas regiões menos desenvolvidas. Confundir ambos nos conceitos de "clientelismo" e "Estado Cartorial" não ajuda a sua compreensão. Como já foi dito, trata-se nas áreas urbanizadas de novo patrimonialismo, distinto do antigo em seu funcionamento e consequiências. As novas instituições políticas, como as novas religiões de massa, correspondem à natureza da nova massa urbana
}

mediúnicas religiões "internalizadas" e não "de tradição", isto é, o caráter de instituições ajustadoras se prende ao papel que desempenham "como fator de 'internalização' da orientação da vida” (p.111), explicável quando a tradição não mais pode guiar frente à "pluralidade de situações imprevisíveis" (p.68) da vida urbana ${ }^{59}$, Mais especificamente o sucesso dessas religiões no meio urbano decorre de sua capacidade de combinar valores internos, organizados racionalmente, com uma interpretação sagrada da vida; de possibilitar ao adepto a explicação pelo sobrenatural dos acontecimentos da vida e por ele pautar suas decisões; e, finalmente, do caráter intelectual dessas religiões, em especial a sua busca de coerência com a ciência e a harmonia de suas idéias com valores e noções prevalecentes no meio urbano (tais como a do progresso individual como prêmio do esforço, a ênfase igualitária e a rebeldia contra as maneiras e etiquetas diferenciadoras tradicionais, e o nacionalismo). Ajunte-se ainda, para compreender o seu papel de ajustamento ao meio urbano-industrial, o enorme esforço assistencial dessas religiões.

Willems, que considera as igrejas pentecostais, das quais possui estudo próprio, junto com as mediúnicas, procede a análise funcionalista, semelhante à de Camargo $^{60}$. Destaquemos apenas aquilo que acrescenta à compreensão já alcançada. Todos os três movimentos religiosos, afirma aquele sociólogo, são compatíveis com o catolicismo e o messianismo das nossas populações rústicas. Como nessas, deparamos no caso das religiões da massa urbana, com flexibilidade doutrinária, com tolerância a inovações, das quais aceita-se o milagre como fonte mais freqüente, e com crenças em experiências místicas, em possessão e em líderes carismáticos. A vitalidade dos movimentos urbanos de massa para esse autor, decorre em parte dessa afinidade com a religião tradicional. Possuem esses movimentos funcionalidade no meio urbano, sem deixar de ter continuidade com a religião rústica. Quanto às funções, formula-as de modo um pouco diverso:

${ }^{59}$ Uma alternativa nessas condições à internalização de princípios e valores orientadores, aponta CAMARGO seguindo RIESSMAN, é a orientação "por outros" que começaria a aparecer em São Paulo. Ver CAMARGO, 1961, págs. 68-69. Os tipos de personalidade other directed e inner directed foram estudados por RIESSMAN (ver RIESSMAN, 1960).

${ }^{60}$ WILLEMS, 1966, especialmente págs. 211-213 e 221-230. 
situam-se entre elas a de minorar "os males físicos e psíquicos", a de reorganizar o comportamento, a de reconstruir para o migrante um grupo primário e a de subverter simbolicamente a estrutura política tradicional ${ }^{61}$.

São, pois, os movimentos religiosos de massa, uma das alternativas pelas quais migrantes, provenientes de estruturas tradicionais (onde a família e a relação patrimonialista com o patrão ${ }^{62}$ davam-lhe certo amparo e segurança), ajustam-se ao meio urbano, aí substituindo os mecanismos tradicionais de proteção e de controle do comportamento. Desempenham esta função, como o salienta Willems, dada a compatibilidade de suas doutrinas e crenças com as do catolicismo rústico. Esses movimentos, no entanto, como religiões "internalizadas" que substituem à "de tradição", representam certo fator de racionalização da vida. Decrescem, pelo menos onde a penetração da sociedade urbano-industrial é maior, na medida que "os valores profanos da vida industrial ganham terreno e se firmam" ${ }^{3}$.

${ }^{61}$ Transcrevamos alguns trechos ilustrativos dessas funções, no caso das seitas pentecostais. "Among the Pentecostals, any leader who demonstrates unusual skill as a miracle healer is likely to draw large crowds (...) The headquarters of [the Pentecostal Church Brazil for Christ] are constantly besieged by a ragged crowd waiting patiently in line for a prayer or a few words of solace from the thaumaturge [Manuel de Mello]. The aspect of the crowd leaves no doubt about the recent rural origin of its components (...) The therapeutical functions of Pentecostalism are not limited to individual healing performances; they seem to play a significant role in the broader context of conversion and the radical change of personal habits (...) The typical Pentecostal congregation is a highly cohesive primary group which tends to absorb the newcomer to an extent unmatched by most established churches (...) The prevalent criteria of class differentiation, such as wealth, family background, education, and occupation are ignored and often deprecated as manifestations of sinful mundanismo or worldliness. Since the Pentecostalists as a class are not allowed by the 'world' to attain distinction in any of these aspects, their validity is altogether denied. In a sense, this is a subversion of the traditional or emerging social order in the language of religious symbolism." WILLEMS, 1966, págs. 222, 223, 225-227.

${ }^{62}$ Ver o capítulo VII.

${ }^{63}$ A sugestão, para o caso das religiões mediúnicas em São Paulo, é de CAMARGO. O trecho merece ser reproduzido: "Pelos poucos indícios que temos, parece-nos que decresce o continuum [kardecismo-umbanda] à medida que os valores profanos da vida industrial ganham terreno e se firmam. Seria, assim, o progresso do continuum característico da fase transitória da vida religiosa do país, fundada na urbanização e no capitalismo incipiente de base econômica agrária ou de recente
Procuremos, num rápido esboço, relacionar, num quadro único, as várias conclusões a que chegamos sobre as mudanças na religião e o processo de secularização, com o desenvolvimento da sociedade global. Com a urbanização, firma-se a Igreja Católica, como parte da hierarquia mundial, nas camadas urbanas médias e superiores. Ao mesmo tempo, os efeitos do mercado, de padrões urbanos e, não raras vezes, dos próprios esforços de controle pela hierarquia religiosa revigorada, desorganizam o catolicismo de folk. Entre os habitantes rurais, a decadência das festas religiosas tradicionais, as quais não são substituídas pela atividade da Igreja (quando mais não fosse pela escassez de sacerdotes), abre um vazio que constitui campo fértil para o proselitismo protestante. Por outro lado, porém, as transformações sócio-econômicas em curso no país, desorganizam áreas rurais - constituindo talvez as condições responsáveis. pelos movimentos messiânicos que nela se repetem - e criam em toda a parte correntes migratórias para as cidades. Nessas, a massa humana recémvinda do mundo rural, encontra em religiões "internalizadas" - as mediúnicas e as seitas protestantes pentecostais - uma das alternativas à insegurança e aos problemas da vida urbana. Ademais, do desenvolvimento do Brasil, pelas transformações políticas que ocorreram, pelos seus contatos culturais mais intensos com o mundo exterior (sobretudo pelo terreno propício a essas influências que mudanças sócio-culturais criaram nessas cidades), decorrem movimentos de renovação no catolicismo urbano e em setores da Igreja. Tais movimentos, por sua vez, intensificam as mudanças da sociedade.

Boa parte dos fenômenos examinados, embora não todos ${ }^{64}$, indicam secularização da sociedade. Vinculam-se, muitas vezes, como se destaca em vários pontos da análise procedida, à individualização do comportamento. Examinemos agora este processo.

industrialização. Somente estudos posteriores poderiam confirmar, Ou não, esta hipótese". C. CAMARGO, 1961, p.92.

${ }^{64}$ Os movimentos messiânicos e o arraigamento do catolicismo de Igreja nas camadas superiores do Brasil urbano não podem, é claro, ser considerados como fenômenos de secularização. 
Profunda e extensa individualização do comportamento está a ocorrer na sociedade brasileira, Não há dúvida de que o processo apresenta estreitos vínculos com o desenvolvimento sócio-econômico, Quando, porém, procuramos caracterizar as formas concretas da mudança social nessa área, encontramos dificuldades. Os estudos, via de regra, são desligados de qualquer concepção geral e apresentam mesmo poucas sugestões, quanto mais análise, nesse sentido.

Dada a proeminência de estruturas de parentesco e da família no Brasil tradicional e sua persistente importância ainda hoje, fato afirmado por todos os estudiosos ${ }^{65}$, individualização entre nós diz respeito sobretudo à transformação de tais instituições. Outro fenômeno, relevante por incidir sobre extensa parte da população brasileira, é a individualização das atividades econômicas no campo. Aqui, em país pobre de formas coletivas de ação mais ampla que a família, cabe tratar da cooperação vicinal nas atividades agropecuárias, do mutirão, adjutório ou ademão, como é variavelmente chamada, nas comunidades rústicas brasileiras.

Vejamos o que é possível afirmar sobre o que ocorre com respeito à família e à ajuda rural, devido à transformação global que se opera no Brasil.

Primeiramente, tratemos da família.

Observa Willems que, o quanto a "estrutura patriarcal e extensa" da classe alta brasileira tem sido estudada e bem definida, tanto é desconhecida a organização familiar das nossas classes baixas rurais ${ }^{66}$, sugerindo ainda "ser menos difícil apreender e descrever as mudanças que sucedem em

\footnotetext{
${ }^{65}$ WAGLEY, seguindo os nossos historiadores sociais, afirma ter sido "the family (...) in the past the most important single institution of Brazilian society”, e acrescenta adiante, "[a large parentela] was an institution of the small elite in which the lower classes of the city and the rural zone participated only marginally. Yet it is my thesis that this institution persists today, as in the past, and that its study is essential to an understanding of modern Brazil". WAGLEY, 1963, págs. 185, 198-199.

${ }^{66}$ Ver WILLEMS. 1953, p.339: "Overzealous compilers, (...) should refrain from generalizing about the Brazilian family in terms of a patriarchal and extended structure. because it is not known whether the family of the lower classes, which represent the overwhelming majority of the Brazilian people, is actually organized along the same times".
}

estruturas sociais precisamente definidas, do que aquelas que afetam estruturas frouxas e mal integradas" ${ }^{\prime 67}$. Esses últimos caracteres sobressaem, na verdade, dos dados existentes sobre as instituições familiares das camadas baixas da população rural. O problema básico é saber se isso sempre foi assim.

Contudo, faz-se mister caracterizar, antes, mesmo que brevemente, a "estrutura patriarcal e extensa" da classe alta tradicional. Os estudos pioneiros neste campo foram os de Gilberto Freyre e Oliveira Vianna. A retomada da questão por Antônio Candido, Emílio Willems e Charles Wagley, permite-nos colocar melhor, talvez, as linhas de mudança ${ }^{68}$, Wagley, de modo especial, mostra bem detalhadamente no que consistia a estrutura patriarcal e extensa do nosso patriciado rural $^{69}$. A parentela era a instituição básica. Tratava-se de "ampla teia de parentesco (...) bilateral", consistindo dos parentes identificáveis do lado da mãe e do pai, e mais ainda nos do cônjuge, estrutura portanto que se estendia muito além do núcleo patriarcal ${ }^{70}$. Além disso, visto como outro princípio estruturador, ou como segmento da parentela, Wagley coloca o que denomina família orientada para um ancestral (ancestor-oriented families), isto é, grupos familiares descendentes, do lado do pai ou da mãe, de um donatário, de um poderoso dono de engenho, de um barão do café, ou mesmo, ainda mais recentemente, de um estadista ou diplomata de grande fama ${ }^{71}$. É a unidades como essas, a que nos referimos ao falarmos dos Junqueiras Ayres da Bahia, dos Prados ou Penteados de São Paulo, ou ainda dos Wanderleys ou Cavalcantis pernambucanos. Embora não esteja explícito em Wagley, para se completar o quadro tradicional, torna-se necessário pôr, como segmento das famílias descendentes de um ancestral comum, os núcleos patriarcais,

\footnotetext{
${ }^{67}$ WILLEMS. 1955 a, p.52.

${ }^{68}$ Ver FREYRE, 8. ${ }^{\text {a }}$ edição, 1954; Oliveira VIANNA, 1949; CANDIDO, 1951; WILLEMS, 1953; e WAGLEY, 1963.

${ }^{69}$ WAGLEY, 1963, págs. 184-204.

70 "It is this parentela, and not the nuclear family or even the patriarchal family, that was traditionally the most important single institution in Brazil (...) It consisted of all recognized relatives on both one's mother's and one's father's side, along with the kinsmen of one's spouse'. Ibidem, p.186. ${ }^{71}$ Ibidem, p.187.
} 
Esses eram os que se mantinham unos em sua propriedade, geográfica e economicamente. Ao núcleo patriarcal ou, talvez, às estruturas mais extensas de que fazia parte, juntava-se, como nos lembra Antônio Candido $^{72}$, "uma periferia nem sempre bem delineada, composta de escravos e agregados, índios, negros e mestiços, entre os quais se incluíam as concubinas do patriarca e seus filhos ilegítimos". Finalmente, como parte central da complexa estrutura de parentesco, na análise correta de Willems $^{73}$, constituem-se constelações de valores, a que chama de complexos de virgindade e virilidade, e sobre os quais se alicerçam os papéis assimétricos do homem e da mulher.

Hoje, as estruturas familiares, das camadas altas e médias da sociedade, exibem combinação intrincada de fenômenos de mudança e persistência. As transformações que nelas se constatam se ligam à industrialização e urbanização,

Os valores centrais, a que se aludiu acima, demonstram notável estabilidade; alterações periféricas, entretanto, associadas às condições de vida urbana, apresentam-se numerosas (coloca-se nesse caso, por exemplo, a cada vez mais ampla aceitação, principalmente nas camadas médias urbanas, do emprego feminino em ocupações outras que não sejam a do ensino). Houve também gradual emancipação, vinda já do século passado e acentuando-se no presente, do patriarcalismo; e, no meio urbano, nem ao menos vestígios subsistem dos núcleos patriarcais de outrora. A estrutura familiar extensa, todavia, sobrevive transformada, mesmo nas metrópoles do Centro-sul. Escreve Emilio Willems:

${ }^{73}$ WILLEMS, 1953, págs. 340-343. O autor esclarece com bastante cuidado as maneiras pelas quais se integravam, segundo aqueles valores, os vários papéis básicos da estrutura. Veja-se, por exemplo, o trecho: "At first glance it may seem improbable that these antithetic roles which largely determine husband-wife, father-daughter, and brother-sister relationships should be integrated into such a closely knit group as the Brazilian family. Actually these roles are adjusted to each other with a minimum of friction or conflict. There is a strict separation between the sex-ridden, overbearing, and irresponsible Brazilian male as he likes to appear to his companions outside his home, and the devoted father and provider as he appears to his family" (p.342)
}

Entrevistados residentes da cidade de São Paulo puderam mencionar de 30 a 500 parentes, parte considerável dos quais vive na mesma cidade. Há a expectativa tácita de proteção e auxilio, até de "primos" distantes, que a pessoa mesmo jamais viu. Nas cidades do Nordeste, um jovem parente do interior pode aparecer inesperadamente para visitar seu tio e com ele permanecer vários anos.

A estrutura familiar extensa persiste, pois, agora como "grupos solidários de famílias nucleares que residem na mesma localidade" Willems acentua também a atuação dos laços familiares extensos, no nepotismo e filhotismo que ainda permeia a administração pública ${ }^{75}$.

Importante, porém, é o virtual desaparecimento nas famílias das classes médias e altas, daquela periferia que mencionamos, constituída por indivíduos e famílias nucleares das camadas inferiores, "descendentes" dos agregados, libertos e escravos do passado. Com o declínio dos núcleos patriarcais, aquela parte da estrutura quando sobrevive, o faz como tênue trama de relações ligando "filhos de criação" e afilhados às estruturas familiares extensas, e isso quase só nas zonas rurais, e nos centros menores do interior.

O que se deve sublinhar neste passo, porém, é serem relacionados, a continuidade de todas essas estruturas mais extensas que as famílias nucleares e o vigor que ainda demonstram, com o grau de urbanização.

Observa, por exemplo, Hutchinson sobre famílias da classe alta no Recôncavo Baiano ${ }^{76}$, ilustrando com certo caso:

A sua vida social (...) contém-se quase inteiramente dentro desse grupo de 97 pessoas [que constitui a família extensa], mais seus parentes afins e suas famílias (...) Amigos (...) se ligam aos vários grupos conjugais e são trazidos para as atividades da família extensa mais ampla.

\footnotetext{
${ }^{74}$ Ibidem, p.343.

${ }^{75}$ WILLEMS, 1945. Note-se, porém, as nossas observações acima (págs. 110-112).

${ }^{76}$ Harry HUTCHINSON, 1957, págs. 129 e 133. Assinale-se que a classe alta dos senhores de engenho em comunidades do Recôncavo é parte da mesma classe em Salvador, onde aliás seus membros residem durante o inverno (Ibidem, págs. 101-102)
} 


\section{Adiante generaliza:}

Apenas vestígios existem do antigo patriarcalismo das famílias de classe A; esses são no entanto ainda importantes: a continuação da relação íntima dos membros da família, embora separados pela distância e pelos interesses; o inter-casamento de primos e o forte padrão da vida de família; o fato que a família como unidade ainda dá ajuda e proteção àqueles membros incapazes de o fazer sozinhos; e finalmente o reconhecimento de um chefe da família extensa, um indivíduo a quem os demais membros, assim como outras famílias, apresentam deferência e respeito.

Famílias extensas desse tipo, poderiam ser notadas entre as classes alta e média de São Paulo e do Rio de Janeiro. Análise aprofundada, porém, a nós nos parece, revelaria incluir essa vida em família, via de regra, círculo menor de parentes, menor freqüência das festas e reuniões de família e maior número, para os seus membros, de relações e amizades desvinculadas da estrutura familiar. Há, todavia, necessidade de estudo comparativo, de profundidade, dessas e de outras diferenças entre regiões e cidades, e principalmente dos fatores que atuam nas mudanças em curso, nas estruturas familiares.

A situação de falta de estudos gerais não é diversa se voltamos a atenção para as camadas baixas. Para Willems, como vimos, a estrutura da família dessas camadas difere bastante da das classes altas. Para elas, ainda para esse autor, o casamento é relativamente instável, os valores ligados à virgindade, à virilidade e à honra da família, são muito mais fracos e menos elaborados, e as estruturas extensas são menos importantes funcionalmente ${ }^{77}$.

Nota ainda o mesmo autor:

77 WILLEMS, 1953, págs. 343-344 e WILLEMS, 1955 a, págs. 46-52. Essas conclusões de WILLEMS são, grosso modo, corroboradas pelos estudos de comunidade realizados no Brasil. Além dos seus (WILLEMS. 1952, págs. 65-78 e 1961, págs. 56-76), ver, entre outros: PIERSON, 1951, págs. 127-143; Borges COSTA, 1955; Borges COSTA, s/d, manuscrito; A. M. ARAÚJO, 1955; HARRIS, 1956, págs. 147-178; Harry HUTCHINSON, 1957, págs. 127-155; Altenfelder SILVA, 1961, págs. 187-206; e CANDIDO, 1964, págs. 184-209.
A frouxidão dessa estrutura [familiar] é provavelmente condicionada pelo fato de não haver foco cultural facilmente perceptível na correspondente cultura da classe. A família de classe média e alta cresceu fortemente na grande propriedade rural, a defesa da qual tinha sido a sua principal preocupação. Nada havia entretanto para a família de camponeses (peon family) concentrar-se - não havia propriedade, nem instituições específicas de qualquer espécie, para atuarem como centro de uma cultura mais integrada. A ausência de foco cultural definido reflete-se no extraordinário grau de movimentos erráticos no espaço que, por seu turno, reforçam a instabilidade existente ${ }^{78}$.

Admitindo-se mesmo que se trata nessas camadas de modalidade distinta de família - e os fatores apontados por Willems nesse trecho são convincentes, - a questão é saber-se até onde essa forma estrutural sempre foi assim ou até que medida está havendo uma acentuação, um afastamento das formas antigas de organização. Há indicações, nos estudos que enumeramos, de fatores de mudança, presos todos à transformação global da sociedade brasileira.

Em exame mais acurado daqueles estudos, quanto à instabilidade da família (a aceitação de uniões livres e da bastardia e a quase normalidade com que se refazem mancebias ou "casamentos" sucessivos, aproveitandose o fato de a comunidade encarar como quase igualmente legítimas tanto a forma religiosa como a civil do matrimônio $)^{79}$, surge essa instabilidade mais nítida e frequientem ente nas áreas mais afetadas pelas novas correntes

\footnotetext{
${ }^{78}$ WILLEMS, 19.53 , p.344.

${ }^{79}$ Ver, a propósito, as interessantes observações de CAMARGO 'sobre os efeitos em Xique-Xique da separação da Igreja e do Estado, com o advento da República, e da gradual evolução de atitudes referentes às duas formas de casamento, onde anota: Provavelmente a maioria ainda se casa exclusivamente no religioso por obediência aos mores da comunidade, mas parece-me crescente o número de indivíduos cuja atitude tende a aproveitar a existência das duas instituições, para constituir uma espécie de casamento experimental". C. P. CAMARGO, 1952, págs. 307-308. HARRIS assinala igualmente para Rio das Contas na Bahia: "Some villagers interpret the fact that there are two forms of marriage ceremony to mean that they have a chance to marry twice". HARRIS, 1956, p.161. No texto o que se aponta é que, quando fatores sócio-econômicos resultam em emigração persistente, tais fatores jurídicos ganham significação e levam a mudanças sociais.
} 
emigratórias, como por exemplo no litoral de São Paulo e Santa Catarina e, sobretudo, no Sertão da Bahia e do Nordeste ${ }^{80}$.

Não há dúvida que as nossas populações rústicas sempre apresentaram acentuada mobilidade, associada à sua agricultura itinerante, e que tal circulação constante poderia ser responsável, não só pela relativa frouxidão e instabilidade da estrutura familiar, como também pela dificuldade dos grupos familiais conjugais integrarem-se em estruturas mais amplas $^{81}$. Entretanto os movimentos de população assumem agora formas novas: realizam-se a distâncias maiores, são mais demorados e englobam não apenas famílias, mas indivíduos isolados, envolvendo alta desproporção quanto ao sexo dos migrantes (com predominância de homens nas do Nordeste e de mulheres, muitas vezes, nas do litoral). O êxodo rural separa com freqüência o indivíduo da família e provoca acomodações em sua estrutura. Tais migrações, como se viu, são parte de transformações no meio rural de origem e nas zonas de imigração ${ }^{82}$; são nos dois pólos, em suma, função do desenvolvimento global que se dá no país.

Outros fenômenos, igualmente vinculados a esse desenvolvimento, provocam também afastamento acentuado entre as formas antigas e as atuais da família rurícola. De fato, observa Antônio Candido que

[a família caipira] sempre consistiu numa forma de ajuste das relações sociais, variando segundo o modo de articulação com os grupos mais amplos e as condições de ocupação do solo.

Entre tais grupos mais amplos, destaca ele os de vizinhança, os bairros rurais e assevera que onde as famílias permanecem neles integradas, observa-se "a estabilização dos costumes e o funcionamento normal das instituições domésticas", pois neles continuam a atuar os padrões sociais e religiosos ${ }^{83}$. Ora, como o demonstra o autor, a crise atual nas unidades

\footnotetext{
${ }^{80}$ Ver, em especial, WILLEMS, 1952; C. P. CAMARGO, 1952; A. M. ARAÚJO, 1955; Altenfelder SILVA, 1961; e Borges COSTA, s/d.

${ }^{81}$ Cf. CANDIDO, 1964, p.207.

${ }^{82}$ Ver, acima, págs. 56 e segs.

${ }^{83}$ Ibidem, págs. 206-207 (grifos nossos).
}

vicinais e na cultura caipira resulta da sua gradual integração no mercado e na civilização urbana ${ }^{84}$. Esse é, portanto, o fator básico da nova acomodação familiar dessas populações ${ }^{85}$.

Entretanto, existia no passado outro "modo de articulação (da família do habitante rural) com grupos mais amplos" e o seu exame nos conduzirá a outra hipótese explicativa da instabilidade e da frouxidão de sua estrutura familiar, pelo menos em certas áreas. Queremos nos referir à ligação do grupo conjugal do agregado, às extensas parentelas das camadas altas. Ele constituía mesmo, como já apontamos, parte da periferia daquelas famílias extensas. Por outro lado, no Nordeste, as mudanças políticas durante a República, pari passu com processos econômicos, teriam representado involução nas áreas menos desenvolvidas, com intensificação do cunho local das oligarquias, incremento do banditismo, etc ${ }^{86}$. Tais fatos podem ter abalado profundamente as famílias mais pobres das zonas rurais. Recorramos mais uma vez ao estudo de Pereira de Queiroz. Apoiada em material histórico, descreve ela as linhagens ou famílias-grandes prevalecentes na área, assinalando ser o grupo consangüíneo:

(...) aureolado por parentes mais afastados, ramos bastardos, afilhados, agregados (...) Além dos laços de sangue, os laços de parentesco religioso determinados pelo compadrio integravam os indivíduos nestes grupos (...).

E ainda:

${ }^{84}$ Ver, acima, págs. 48-49; ver também o trecho sobre a cooperação vicinal, abaixo, págs. 146-147.
${ }^{85}$ Todo o estudo de Antônio CANDIDO, não há dúvida, fornece-nos elementos para acreditar-se
haver, de fato, certa constância na instabilidade da vida do rurícola, na medida em que ela se ajustava
à tendência dessas populações para a mobilidade. Assim, as condições de isolamento do posseiro -
condições ciclicamente se reproduziriam durante o processo de ocupação da terra - estariam ligadas
a acomodações familiais específicas, e, em casos extremos, mesmo a nítidas manifestações de
desorganização derivadas da ausência de controles grupais. Entretanto, nesse caso, com o
povoamento e a constituição da vida social dos bairros rurais, desaparecia a anomia. As novas
condições econômicas e aos novos movimentos de migração, devido ao desenvolvimento, sucedem-
se, pelo contrário, transformação da família num dado sentido e integração à vida urbana. Essa é a
nossa hipótese. 
O fazendeiro, em geral, faz benefícios e favores materiais aos agregados - cessão de terras, empréstimos, etc.; (...) ligando pela lealdade o agregado ao fazendeiro que deste se torna o homem, apoiando-o nas lutas eleitorais ou outras.

Adiante, quando a mesma autora caracteriza a desorganização social que se estabelece na área ${ }^{87}$, trata dos seus efeitos sobre a família, mencionando mesmo terem em certas áreas as linhagens:

(...) [se] esfarelado numa multidão de famílias menores. A desordem [aí] era ainda maior. Ao nível da própria família conjugal a estrutura praticamente desaparecia, uma vez que o marido abandonava facilmente a mulher ou vice-versa (...).

Os padrões familiares de auxílio mútuo, respeito aos mais velhos, fortalecimento da solidariedade dos parentes, fidelidade conjugal, virgindade da jovem, assim como o apoio dado pelos de mais posses aos menos beneficiados, persistiam apenas como valores, mas não eram seguidos nos comportamentos efetivos ${ }^{88}$.

Nessa região, pois, o desprendimento das famílias de homens do coronel, seus afilhados e agregados, das pirâmides familiares da classe alta, processo condicionado econômica e politicamente, ocorrendo há várias décadas, jaz na raiz da profunda mudança e desorganização da instituição doméstica.

Todas essas transformações da família, seja a das camadas altas, seja a das baixas, nas cidades e nos campos, embora próximas a fenômenos de desorganização, provocam contudo clara individualização da conduta. Esse processo assume modalidades diversas; condicionadas pela forma concreta do desenvolvimento em curso no Brasil ${ }^{89}$.

\footnotetext{
${ }^{87}$ Ver, acima, págs. $128-130$.

${ }^{88}$ Grifos nossos; Pereira de QUEIROZ, 1965, págs. 290-291 e 295.

${ }^{89}$ Deixamos de lado a família das camadas inferiores urbanas, a proletária e a da pequena classe média, pois, sobre ela, os estudos são pouquíssimos e superficiais. Alguns merecem menção. Thales de AZEVEDO, em análise de dados para quase 1.400 operários de fábricas (associados do instituto de previdência), em 1946-47, em Salvador, dá-nos alguns elementos sobre as instituições do casamento e família entre eles, que nos fazem lembrar os da família rural pobre (aceitação do
}

Constituem igualmente individualização o declínio das atividades vicinais no campo. E nesse caso, a causa não padece dúvida. Trata-se antes de tudo de comercialização do comportamento econômico, que atende à penetração do mercado em áreas antes imersas em economia de autoconsumo.

Essa, de fato, é a conclusão da pesquisa admirável de Antônio Candido, de que nos valemos mais de uma vez nessa monografia ${ }^{90}$. Mostra, em síntese, que a cultura caipira em São Paulo caracteriza-se por um nível mínimo vital (representado pela dieta frugal, obtida com tecnologia rudimentar, da qual a cooperação vicinal é elemento integrante), em delicado ajuste a um mínimo social (a sociabilidade de bairro, com as suas festas religiosas e, de novo, a ajuda mútua, agora nos seus aspectos sociais). $\mathrm{O}$ auxílio vicinal, junto ao isolamento do bairro, à disponibilidade relativa de terras, à homogeneidade cultural, à coesão resultante da sociabilidade das festas religiosas, à exígua força de trabalho doméstica e à margem de lazer, fazem parte de um todo integrado, no qual todos são elementos mutuamente dependentes. A penetração de produtos do mercado altera as necessidades do caipira, obrigando-o a produzir para vender, intensificando o ritmo de seu trabalho, destruindo-lhe assim as formas de cooperação vicinal e as festas recreativo-religiosas.

\section{Conclui Antônio Candido:}

casamento religioso sem o civil; prevalência de uniões livres). Entretanto, embora afirme que "existe um tipo de família natural, sem forma legal, a qual se aproxima da [legitimamente constituída] em seu funcionamento e na sua estabilidade, mas [que é perturbada] por um sistema próprio e informal de 'divórcio' ou separação e pela poligamia (poliandria sucessiva e poliginia sucessiva e simultânea)", não nos dá dados suficientes para aquilatar o grau de instabilidade, ou mesmo de desorganização, se existente. T. AZEVEDO, 1948, págs. 15-19. René RIBEIRO compara o familismo na classe média, em sua ligação com a urbanização, entre 40 famílias de Recife com 50 de Bezerros (cidade de cerca de 8.000 habitantes, no interior de Pernambuco), chegando a resultados, no geral, inconclusivos. Não nos parece possível, no entanto, usar seus dados, por ser difícil a interpretação dos quadros, sem se ter as perguntas do questionário. Também o fato de o autor não ter controlado o número de parentes, para as famílias consideradas em cada comunidade (e, portanto, os efeitos das migrações), tira quase todo o sentido das comparações que faz da interação com parentes e não-parentes em várias situações. R. RIBEIRO, 1961

${ }^{90}$ CANDIDO, 1964. 
A expansão do mercado capitalista não apenas força o caipira a multiplicar o esforço físico, mas tende a atrofiar as formas coletivas de organização do trabalho (mormente ajuda mútua), cortando as possibilidades de uma sociabilidade mais viva e de uma cultura harmônica. Entregue cada vez mais a si mesmo, o trabalhador é projetado do âmbito comunitário para a esfera de influência da economia regional, individualizando-se $\mathrm{s}^{91}$.

Levantamento geral das formas de ajuda mútua no meio rural brasileiro, realizado por Clóvis Caldeira ${ }^{92}$, fornece-nos elementos para aceitarmos a generalidade do mecanismo de transformação identificado por Antônio Candido.

Realmente, conclui aquele autor ser a causa principal da decadência da cooperação vicinal:

(...) a transformação, em várias zonas, da economia de subsistência em economia comercial, determinada quer pela abertura de vias de comunicação quer pelas crescentes exigências alimentares das grandes concentrações urbanas (...).

No decurso do texto, Caldeira enumera outros fatores relevantes conducentes ora à persistência das formas de cooperação vicinal, a saber, "o baixo nível técnico das atividades agrícolas brasileiras, que continuam a basear-se, de modo geral, na força muscular do homem", a impossibilidade de explorações familiais utilizarem-se de mão-de-obra assalariada, e o êxodo rural, ao restringir as disponibilidades de mão-de-obra nas zonas de origem; ora conducentes ao desaparecimento da ajuda mútua, como "o elevado custo dos alimentos" a criar empecilhos para alimentar e oferecer bebidas a numerosas pessoas. Não é preciso refletir muito para concluir que todos esses fatores são coerentes com o processo básico de mudança que sobressai na pesquisa de Antônio Candido. Em todo o país, o mutirão está decadente; desaparece sob o impacto do mercado ou é substituído por

\footnotetext{
${ }^{91}$ Ibidem, p.133

${ }^{92}$ CALDEIRA, 1956, particularmente o capítulo V, "Cooperação no meio rural brasileiro. Estado atual - Tendências", págs. 83-95 (a citação é da p.84)
}

formas contratuais de trocas de dias de serviço ${ }^{93}$, ocorrendo constante individualização do trabalho ${ }^{94}$.

As instituições familiais da camada senhorial do passado sobrevivem ainda, modificadas, nas classes altas e médias urbanas: os seus valores centrais apresentam surpreendente resistência à mudança; a extensa estrutura de relações que as caracterizava perdura, sob a forma de "grupos solidários de famílias nucleares que residem na mesma localidade" (Willems). Isso ocorre mesmo nas cidades grandes; nas metrópoles Rio e São Paulo, todavia, já se podem notar diferenças, no sentido de maior individualização. (A persistência, mesmo com a urbanização, do grupo conjugal grande, com os padrões e valores a ele associados, é indicada pela pouca difusão de práticas anticoncepcionais no Brasil urbano, excetuandose apenas as grandes metrópoles; ver o apêndice a este capítulo.) Ademais, em todo o Brasil permanece a importância dos laços extensos de parentesco na vida político-administrativa.

Nas camadas inferiores da sociedade rural brasileira, a família apresenta-se diversamente da dos outros níveis sociais. A sua estrutura é frouxa, o casamento mais instável, muito menores a ênfase e a elaboração dos valores ligados à honra, à virilidade e à virgindade. Nessas camadas a instituição pode ter sido sempre diferente da família patriarcal da camada senhorial. Há muitas indicações, porém, que aqueles traços (e outros mais claramente de desorganização) acentuaram-se com as condições ligadas à transformação global da sociedade. Encontramos entre tais condições, de um lado, antigo processo de desvinculação da família do rurícola das extensas parentelas do patriciado rural e, do outro, mais acentuadamente no presente, a sua desarticulação dos agrupamentos de vizinhança (bairros rurais), devida à penetração do mercado no meio rural e à migração ruralurbana.

\footnotetext{
${ }^{93}$ Ver CANDIDO, 1964, págs. 98-101 e CALDEIRA, 1956, p.93.

${ }^{94}$ Há outras formas de individualização, além das que se prendem às transformações da família e ao declínio da ajuda mútua no campo. Essas últimas parecem-nos situarem-se entre as mais profundas mudanças em curso. Por isso, examinamo-las.
} 
Finalmente, vimos como os mesmos fatos - movimentos populacionais e crescente incorporação da economia do rurícola ao mercado - são a causa do mesmo fenômeno de individualização do comportamento do homem do campo sob outro aspecto, isto é, o do declínio das atividades vicinais no Brasil rural.

Encontramos aqui, talvez, o processo mais profundo e extenso de individualização em curso na sociedade brasileira, seja ele examinado sob o aspecto das transformações na família do rurícola, ou sob o das mudanças de suas atividades econômicas.

Trataremos no próximo capítulo de outros fenômenos ligados à formação da sociedade urbano-industrial em nosso país, a saber, a natureza e o comportamento de novos grupos sociais e a influência dos meios modernos de comunicação sobre atitudes e valores.

\section{Apêndice: Controle da natalidade}

No âmbito da sociologia da família, deve ser sucintamente tratada, ao menos em apêndice, a questão do controle da natalidade. Essa conduta, derivada de fatores psicossociais complexos, ligados sempre às condições e influências urbanas, é indicadora da racionalização da vida de família, parte de processo de secularização (devido ao enfraquecimento dos controles da religião tradicional). Por sua vez, a diminuição decorrente no tamanho da família liga-se aos fenômenos muito mais gerais de transformação da estrutura e funcionamento das instituições familiares como foram examinadas, e por isso é pertinente à individualização do comportamento que se processa na sociedade.

Aqui nos limitaremos a rápido exame da literatura sobre o assunto ${ }^{95}$ para balanço da extensão da prática anticoncepcional e das suas tendências.

São sabidas as dificuldades, no caso brasileiro, de cálculo de taxas de natalidade e de fertilidade, por deficiências do nosso registro civil e falhas

\footnotetext{
${ }^{95}$ Recorremos principalmente aos trabalhos de TIETZE, 1958; MORTARA, 1963; MIRÓ, 1964; B. HUTCHINSON, 1965; KAHL, 1965; e IUTAKA, 1965.
}

dos resultados censitários referentes aos vários grupos por sexo e idade. Utilizam-se pois os diversos autores de estimativas daqueles índices e de outros que os substituem. Nosso interesse é resumir os seus resultados, quanto: 1) às diferenças de natalidade e fertilidade - como índices de mudança de comportamento relativo ao casamento e à família, - entre grupos rurais e urbanos e dos vários níveis sociais (relacionados com urbanização em ambos os casos; lembremo-nos da origem rural de grande proporção das nossas camadas inferiores urbanas); 2) às tendências desses fatos no tempo. Utilizaremos também, além das estimativas mencionadas, dados obtidos em levantamentos especiais, referentes a normas sociais sobre fertilidade e diretamente quanto a métodos anticoncepcionais e atitudes para com eles.

Os vários índices que foram calculados revelam diferenças de níveis de natalidade e fertilidade para as populações rurais e urbanas e para os vários grupos sócio-econômicos. Tietze, por exemplo, calcula com dados do censo de 1950, para populações de vários graus de urbanização, o número de crianças com menos de 5 anos por 1.000 mulheres de 15 a 49 anos de idade ${ }^{96}$. O índice obtido é ao redor de 360 para o Rio e São Paulo; 429 para as outras cidades com mais de cem mil habitantes; 499 para as demais populações urbanas; e alcança 778 para as zonas rurais.

Mortara considera que tais diferenças de fertilidade entre o campo e a cidade no Brasil resultam mais da alta proporção de solteiros e do casamento mais tardio, entre as populações urbanas, do que do controle da natalidade $^{97}$. Pelo menos nas grandes metrópoles, entretanto, esse último fator vem atuando há bastante tempo, principalmente nas camadas altas. Nessas metrópoles surgiram diferenças bem sensíveis de fertilidade entre as várias classes, principalmente devido ao uso de métodos anticoncepcionais.

${ }^{96}$ TIETZE, 1958, p.87. Esse índice é considerado pelos demógrafos de maior validez que as taxas de natalidade calculadas com os dados extremamente precários do registro civil. Ele é, entretanto, afetado por uma série de fatores (níveis de mortalidade de crianças e mulheres, estrutura de idade da população feminina, falhas na enumeração censitária de crianças e movimentos de população), além de sê-lo pelos níveis de fertilidade.

${ }^{97}$ MORTARA, 1963, p.661. 
É o que nos mostra levantamento feito pelo Centro Latino-Americano de Pesquisas Sociais em 1963-64, entre amostra estatística de cerca de duas mil e quinhentas mulheres de 20 a 50 anos na cidade do Rio de Janeiro. Hutchinson utiliza os dados obtidos para calcular o número mediano de nascimentos vivos por mulher casada para seis grupos sócio-econômicos, constituídos com base na ocupação do marido. São os seguintes os resultados: entre os níveis de ocupação manual (não e semiqualificados, e qualificados): 3,58 e 2,77; entre os não-manuais de nível médio (subdivididos em baixas e altas): 2,63 e 2,03; e nos níveis mais altos da hierarquia (cargos de gerência e direção, e profissionais liberais e altos cargos administrativos): 2,24 e 2,45 ${ }^{98}$. É a forma costumeira de relação inversa entre fertilidade e status, inclusive no que se refere à inversão da relação na extremidade superior da escala.

Iutaka ${ }^{99}$ analisa os dados da mesma pesquisa, relativos às práticas de controle da natalidade, mostrando que o haver cogitado ou não no número de filhos desejáveis (como primeiro indício de propensão ao controle), o conhecimento de métodos anticoncepcionais, a sua aceitação como métodos legítimos em quaisquer circunstâncias ou apenas por determinadas razões, e o seu uso, são todos fatos ligados ao status social e à idade. Sobressai em suma dos resultados, o quadro costumeiro de uma aceitação cada vez maior dessas práticas, processando-se das camadas superiores para baixo. Esse fenômeno, sem deixar de ser de estratificação, não deixa também de ser, entre nós, vinculado à urbanização, dada a maior proeminência da origem rural nas camadas inferiores. Destaquemos alguns resultados. No Rio, cerca de 60 por cento das mulheres haviam em algum momento utilizado métodos

\footnotetext{
${ }^{98}$ B. HUTCHINSON, 1965, p.15. Mostra ainda o autor a influência da mobilidade vertical (medida pela comparação do status ocupacional paterno com o do marido) sobre a fertilidade: o seu nível situa-se, então, em posição intermediária entre os grupos de partida e de chegada (idem, p.20). Esse resultado, coerente com o de outros países, relaciona-se indiretamente com a migração rural-urbana, por intermédio da qual se realiza muitas vezes a mobilidade vertical. A hierarquia ocupacional usada nesses estudos e no de IUTAKA, citado abaixo, baseia-se no prestígio das ocupações, e foi validada para o Brasil por HUTCHINSON e CASTALDI. Ver B. HUTCHINSON e outros, 1960, págs. 1951.

${ }^{99}$ IUTAKA, 1965 (a citação é da p.113)
}

de controle da natalidade. Essa proporção sobe, regularmente, da camada sócio-econômica mais baixa para a mais alta, de 41 para 75 por cento. Ligava-se, menos acentuadamente, à idade. A aceitação da limitação de nascimentos (indicativa de desprendimento dos valores tradicionais) varia também com o status social e a idade. Por exemplo, entre as mulheres com mais de 50 anos, cerca de um quarto achava que a limitação de nascimentos nunca se justificava; entre as mais jovens (até 30 anos), menos de um décimo tinha essa opinião. Há, finalmente, indicação de conflitos de atitudes e comportamento. Quase um quinto das que, na época da pesquisa, adotavam práticas anticoncepcionais, atestavam não as usar sempre. "Parece haver um choque" - comenta o autor - "entre dois tipos de problemas: por um lado a tradição de que a família tem como uma das suas funções básicas dar muitos filhos, e por outro uma vontade de controlar o tamanho da família".

Quais as tendências, no país como um todo, do comportamento da natalidade? O cômputo de taxas globais (estimativas), em geral, não indicam qualquer queda ${ }^{100}$. Análises mais cuidadosas, porém, dos dados do censo de 1950, por população urbana e rural, do número de filhos tido por mulheres dos diversos grupos de idade, mostram estarem aumentando as diferenciais urbano-rurais de natalidade, porque enquanto as taxas rurais permanecem estacionárias em nível alto, as urbanas começam a cair ${ }^{101}$. As razões mais importantes desta queda são, provavelmente, para a maioria dos centros urbanos, as apontadas por Mortara: a diminuição da proporção de casados e o atraso do matrimônio. No caso das grandes metrópoles, como vimos, espalham-se práticas anticoncepcionais. $\mathrm{O}$ mundo rural, por seu

${ }^{100}$ A CEPAL fornece, por exemplo, as mesmas estimativas da taxa de natalidade brasileira, 43-47, para os períodos 1945-50 e 1955-60. MIRÓ, 1964, p.35.

${ }^{101}$ Isso é indicado pelo fato de as taxas para as mulheres mais velhas (as dos vários grupos com mais de 150 anos de idade) das populações rurais, serem do mesmo nível que a taxa para o grupo de 45 a 49 anos; para as populações urbanas, as taxas nos grupos mais velhos são sempre mais altas. A análise foi feita pelo Centro Latino-Americano de Demografia. Ver MIRÓ, 1964, págs. 36-37. 
lado, a esse respeito, permanece ainda, grosso modo, intocado pela urbanização $0^{102}$.

$$
* * *
$$

Dois objetos de estudo são de relevância básica para o esclarecimento da sociedade urbano-industrial no Brasil: um é a reestratificação em curso, nos seus laços com o desenvolvimento econômico; e o outro é a intensificação, com o mesmo, dos contatos e comunicações entre todas as "regiões" da sociedade - aspecto da crescente integração nacional - e as mudanças correspondentes nos valores e atitudes sociais. Ambos, e mais os processos gerais examinados no capítulo anterior, formam, sob ângulos distintos, o cerne da transformação social brasileira quando vista da perspectiva da sociedade que se constitui. O reverso dessa perspectiva, a desagregação da sociedade patrimonialista, merecerá nossa atenção no próximo capítulo, o último desta monografia ${ }^{103}$.

${ }^{102}$ Dados sobre a norma social de fertilidade, obtidos por KAHL, em pequenas cidades de Minas Gerais e Rio Grande do Sul, e no Rio de Janeiro, corroboram essas conclusões: verifica-se associação inversa pronunciada entre o número de filhos considerado ideal "para uma família de nosso tempo", e residência, na metrópole ou em cidades interioranas. Deve-se notar que esse foi um dos únicos dados dessa pesquisa que apresentou maior associação com localização na metrópole ou no interior, do que com status social. Ver a parte do capítulo IV, intitulada "Values and Fertility Norms", em KAHL. 1965.

${ }^{103}$ As limitações da linguagem dão a ilusão de que se está estudando fenômenos distintos, que se somariam vara completar a transformação global. Trata-se mais de ver o mesmo processo, iluminado de diferentes lados. Burocratização, secularização e individualização dizem também respeito a mudanças de valores, assunto que trataremos de modo mais direto neste capítulo. A burocratização vincula-se obviamente ao aparecimento de novos grupos no sistema de estratificação social. A desagregação da ordem patrimonialista, envolvendo mutação nas relações de coronéis e patrões com seus "homens", assim como rearticulações dos primeiros na camada dominante nacional, é também parte do mesmo processo de reestratificação. E assim por diante. A sequiência de tópicos justifica-se apenas pelo encadeamento do raciocínio. A consideração dos contatos e meios modernos de comunicação serve, por exemplo, como’ passagem para o estudo das mudanças no patrimonialismo

\section{Industriais, novas classes e médias e operariado}

Profunda desestratificação e reestratificação sociais vêm ocorrendo no Brasil com o seu desenvolvimento. Focalizaremos nesta parte os aspectos associados ao aparecimento dos novos agentes: os industriais, as novas classes médias e o operariado ${ }^{104}$. Destacaremos, embora não exclusivamente, a dimensão poder da estratificação ${ }^{105}$.

$\mathrm{O}$ relacionamento daqueles agentes com a transformação global do país não é simples. Não se trata, como pareceria por exemplo no caso do empresário industrial e do desenvolvimento econômico, da relação de protagonista com a sua ação ${ }^{106}$. O desenvolvimento decorre do jogo de forças sociais e, ao mesmo tempo, tais forças se forjam no seu curso. De um lado temos o desenvolvimento como resultado do entrecruzamento das ações dos vários grupos e movimentos sociais, numa dada configuração estrutural; do outro, constituem-se (ou se reconstituem) nesse processo de mudança o modo de ser e agir daqueles grupos (latifundiários, burguesia mercantil, industriais, camadas médias urbanas e massas populares), assim como se altera a cena de sua ação.

Examinemos em largos traços o tema, focalizando de início os industriais ${ }^{107}$. Para situá-las hoje no quadro de transformações da

${ }^{104}$ Podemos ser sucintos. As pesquisas são relativamente poucas e nós já tratamos do assunto em trabalhos monográficos (ver LOPES, 1964 e 1967). O que é preciso neste momento é, com base nuns e noutros estudos, formular uma interpretação geral, sob a perspectiva que interessa a este

trabalho.
${ }_{105}$ Adotamos a conceituação weberiana. Ver LOPES, 1964, págs. 162-168, onde os conceitos de Adotamos a conceituação weberiana. Ver LOPES, 1964, págs. 162-168, onde os conce

${ }^{106}$ F. H. CARDOSO, 1964 (a), p.74 e passim

${ }^{107}$ A mais completa pesquisa sobre o assunto e cuja análise é incisiva é a de CARDOSO, 1964 (a). Estudou o empresário industrial em São Paulo, Belo Horizonte, Recife, Salvador e Blumenau, com informações obtidas em questionário aplicado a amostra de noventa e cinco empresas com quinhentos ou mais empregados, do "Grande São Paulo", e em oitenta e duas entrevistas com o principal dirigente de empresas de São Paulo e das demais cidades. O mesmo autor vem agora ampliando o trabalho para outros países latino-americanos, tendo divulgado em comunicação a um congresso científico os resultados preliminares de suas reflexões (1965 (b)). Nos parágrafos seguintes, usamos suas conclusões, com algumas divergências de ênfase (ver especialmente texto e nota 138 , na p.167), procurando ao mesmo tempo corroborá-las com material de outros estudos e 
organização social é preciso, pois, ver como surgem e se formam, como camada, no processo do desenvolvimento.

Com esse propósito será útil inicialmente rever, de modo sucinto, a ação do Governo (sempre de importância capital para o nosso desenvolvimento) em três momentos em que ocorreram surtos de industrialização: no final do século passado, nos anos 30 do atual, e no período que se segue à Segunda Guerra Mundial ${ }^{108}$.

No primeiro decênio da República, as principais características da ação estatal que levaram ao desenvolvimento da indústria foram: 1) a política de livre flutuação cambial que, durante todo o período de declínio do setor de exportação (cafeeiro) no último quartel do século XIX significava de um lado a "socialização das perdas" desse setor e, de outro, o encarecimento de produtos industriais importados (portanto proteção); 2) as tarifas altas e a política de dinheiro fácil dos primeiros Governos republicanos que entrosavam também interesses dos industriais com os da classe agrária-mercantil. A elevação tarifária resultou de campanha dos industriais têxteis. Estendia-se a eles assim, na expressão de Stein, "o princípio do auxílio do Governo (government patronage) à empresa agrícola, nos períodos de crise". Não chegava, porém, a contrariar os interesses agrários. A política financeira, que desembocou no "encilhamento" (mas que deixou claro saldo positivo de desenvolvimento depois da débâcle), atendia tanto aos interesses da indústria como aos da lavoura e do comércio exportador. Acresce que uns e outros entrelaçam-se, principalmente nesse período (investimentos de capitais de membros da camada senhorial e mercantil em fábricas têxteis) ${ }^{109}$. Estabelece-se nesse

análises. Nesse sentido utilizamos também, entre outros, os escritos de STEIN, 1957 (b), STRASSMANN, 1964, L. C. B. PEREIRA, 1964, LEEDS, 1964, IANNI, 1965 e FURTADO, 1965. O nosso principal interesse, não custa repeti-lo, é compreender o industrial à luz dos modos concretos pelos quais, como vimos analisando, se constitui a sociedade urbano-industrial no Brasil.

${ }^{108}$ Sobre as condições econômicas favoráveis à industrialização nesses momentos ver acima, na primeira parte, as págs. 10-20. Relaciona-se o tema que ora tratamos com o da transformação política, que foi versado no capítulo $\mathrm{V}$.

${ }^{109}$ Sobre todo esse período ver o capítulo VII, "Industry and Government" do livro de STEIN (1957 (b), págs. 81-97; a citação foi da p.82). Note-se a afirmação desse autor no sentido de que "as late as período a importância básica das medidas governamentais para a prosperidade da indústria, assim como o padrão de lucros altos, num mercado protegido.

Em 1930, a Revolução de Outubro substituíra no poder os fazendeiros e comerciantes de café, cujo interesse era antes quase hegemônico, por uma composição mais heterogênea onde ao lado de frações da oligarquia aparecia o tenentismo, vinculado às classes médias urbanas $^{110}$. À queda de preço do café no mercado internacional, somava-se também a superprodução. O Governo, que pregara o abandono da política de defesa do café, face à crise que atingia a principal riqueza da Nação, não pôde "entregar a lavoura à própria sorte, o que significaria lançar o país inteiro no caos econômico" ".111. Compra os excedentes de café para estocagem ou para queima, defendendo assim uma "política inspirada pelos interesses do café, ou concebida para contentar a esses interesses" ${ }^{112}$. Embora fosse esse o principal sentido dessa política, não era ela alheia ao objetivo de manter o nível de emprego e aos interesses da burguesia industrial nascente. De qualquer forma ela objetivamente significou manter a procura efetiva para produtos manufaturados, quando a importação se achava estrangulada. Decorreram daí ótimas condições para a substituição

1930 the [textile] industry obtained its concessions and privileges from the state without seriously affecting other interest groups" (p.187). Há nesse livro numerosas informações sobre as vinculações dos industriais, quanto a valores e visão do mundo, no período anterior à Primeira Guerra Mundial, com os fazendeiros e comerciantes do setor exportador. Uma citação é especialmente significativa. "The importance of Brazilian planters and plantations between 1870 and 1914 may account for patterns of activity in the cotton manufacture: paternalism in labor relations, the role of the slate, tardy response to change - a conservatism inherited from the landholding aristocracy and merchant oligarchy, the elite group of Brazilian society in the nineteenth and early twentieth centuries" (págs. 186-187).

${ }^{110}$ O programa do tenentismo tinha "um cunho acentuadamente pequeno burguês". Ver SANTA ROSA, 1933, p.114 (apud IANNI, 1965, p.141).

${ }_{111}^{111}$ VIEIRA DA CUNHA, 1963, págs. 51-52.

${ }^{112}$ FURTADO, 1965, p.131. 
de importações por produtos nacionais que vinham ocupar mercado preexistente $^{113}$.

Depois da Segunda Guerra Mundial, a política que resultou industrializadora teve, também, por objetivo primordial a defesa dos interesses do setor cafeicultor:

Em 1946, com o objetivo de defender os preços do café no mercado internacional, quando ainda havia vultosos estoques no Brasil, o Governo brasileiro manteve a paridade do cruzeiro que havia prevalecido durante a guerra, não obstante o nível de preços se houvesse elevado muito mais no Brasil do que nos EUA já se sabia, por experiência, que a desvalorização do cruzeiro significava imediata queda do preço internacional do café, com repercussões adversas para a balança de pagamentos do país. Ao tomar essa providência, que significava preços baixos para os produtos importados, o Governo brasileiro desconsiderava totalmente os interesses da indústria tanto mais quanto a tarifa brasileira era específica, não acompanhando sequer a elevação dos preços no mercado internacional ${ }^{114}$.

Esgotaram-se rapidamente nossas reservas cambiais e. o Governo preferiu, a desvalorizar o cruzeiro, introduzir o controle de importações, dando prioridade, para "manter o nível de emprego nas indústrias já existentes", à importação de matérias-primas e equipamentos, e tornando virtualmente impossível importar o que já se fabricava no país. Assim, além de se considerar o interesse dos industriais, levava-se também em conta os da massa assalariada urbana, que se projetava na consciência da Nação, pela inquietação popular do momento. Na realidade a política de fixação da taxa cambial e controle de importação escondia nas suas consequiências conflitos entre os interesses latifundiário-exportadores e os da acumulação de capital industrial. Subsidiava-se essa acumulação à custa da transferência de renda do setor cafeicultor, renda, porém, que se achava em crescimento devido à

113 Conforme análise de FURTADO em seus vários livros. Ver por exemplo FURTADO, 1959, págs. 217-226. Escreve o mesmo autor: "Entre 1929 e 1937, enquanto as importações declinam em 23 por cento, a produção industrial cresceu em 50 por cento" (1965, p.131).

${ }^{114}$ FURTADO, 1965, págs. 131-132. melhoria do preço mundial do café. Quando este preço começou a cair lá pelo meio dos anos 50, os protestos contra o "confisco cambial" passaram a se fazer ouvir ${ }^{115}$

Até então, como se vê, todas as medidas tomadas pelo governo visavam, antes de mais nada, o setor exportador, ou pelo menos o satisfaziam também. O Brasil é ainda concebido como "país essencialmente agrícola". Surtos de industrialização resultam indiretamente daquelas medidas, dada a existência de conjunturas econômicas propícias, surtos que se apresentam assim como decorrência secundária, não diretamente objetivada $^{116}$.

Agora, no entanto, principiara a surgir na confluência dos interesses dos vários grupos sociais, um movimento social pelo desenvolvimento nacional. A urbanização que se assentara na industrialização já ocorrida, junto com o crescimento e racionalização que já se operara no setor público, provocaram a emergência de novos grupos sociais urbanos, relativamente desvinculados da estrutura de poder da sociedade tradicional: novas classes médias e massas populares. A partir de 1946, com a constitucionalização do país, a sua presença se fez sentir crescentemente, formando-se aos poucos uma política industrializadora. Cardoso caracteriza como ocorrendo em dois "momentos", o aparecimento de políticas governamentais visando deliberadamente o desenvolvimento econômico. No primeiro momento, o movimento social "nacionalista" teve a impulsioná-lo grupos sociais vinculados às antigas e novas classes médias (estudantes, profissionais liberais, funcionários públicos, técnicos, etc.). Nesse, como no seguinte, agiu como catalisador a presença, na cena política, das massas populares, engajadas no processo por intermédio das lideranças populistas: era "um

${ }^{115}$ Ver FURTADO, 1964, págs. 121-122 e SINGER, 1965, págs. 87-90.

${ }^{116}$ Até esse momento, de fato, "o jogo de intenções desencontradas dos resultados parece guiar toda a política de defesa dos cafeicultores que resulta no fortalecimento dos industriais". A crítica de CARDOSO a esse ponto de vista (1964 (a), págs. 72-84) só é válida para os últimos decênios, quando surge a industrialização como política deliberada. A industrialização e o crescimento da população' urbana, que ocorreram no período anterior, são fatos decorrentes do "acúmulo de equívocos e desencontros" essenciais para explicar o movimento social no período de transição mais recente (a partir de 1944 ou 1945). 
novo interlocutor que, embora afônico, marcou com sua presença o início da quebra das soluções rotineiras dos problemas nacionais". A Campanha do Petróleo é o exemplo mais relevante do impulso pela "emancipação econômica", que, segundo as idéias nacionalistas, seria promovida pelo Estado. Num segundo momento, o setor industrial, que permanecera até aí à margem do movimento, é permeabilizado por essas idéias, embora com aceitação bem menor dos valores de cunho estatizante. O "nacionalismo" é transformado em "desenvolvimentismo"; na década dos anos 50 concretizam-se medidas, deliberadamente favoráveis à industrialização, com a entrada em grande escala de capitais estrangeiros nas indústrias mecânicas e pesada (os fatos a lembrar são a Instrução 113 e a instalação do parque automobilístico $)^{117}$.

O processo de formação social dos empresários industriais marca o seu papel no plano da empresa e no da sociedade. Enumeremos alguns dos principais aspectos desse processo, como ressaltam da exposição feita sobre os vários surtos de industrialização.

1) Os surtos descontínuos da industrialização brasileira devem-se, antes de tudo, a rupturas parciais na nossa articulação, como economia exportadora, com o mercado mundial (declínio de preços de produtos de exportação, guerras mundiais, depressão da década dos 30), às quais se juntaram políticas que se configuravam propícias à indústria substitutiva de importações. Tais políticas, no princípio, atendiam basicamente aos interesses da antiga oligarquia latifundiária-mercantil. A indústria surgiu, então, como subproduto, não como resultado colimado deliberadamente. Contudo era subproduto que não contrariava os interesses da antiga camada alta; pelo contrário, além de ser política basicamente do café, atendia esse setor ainda de outro modo, pois em momentos de crise da economia de exportação a indústria oferecia possibilidades lucrativas de inversão de capitais.

2) Nesse processo, os interesses de industriais, interesses num sentido econômico e social amplo (compreendendo atitudes, valores e visão do

${ }^{117}$ CARDOSO, 1964 (a), págs. 84-92 (a citação é da p.86). mundo), surgiram enlaçados aos das famílias de donos de terra e da alta burguesia comercial, isto é, aos de membros do setor exportador, e deles nunca chegaram bem a diferenciar-se.

3) Nas várias ondas de industrialização, principalmente a partir de 1914 em São Paulo, juntam-se à camada empresarial descendentes de imigrantes de vária extração étnica,com origem social nas camadas médias e inferiores das populações urbanas, o que aumenta a heterogeneidade do empresariado.

4) A industrialização no Brasil não resultou de projeto de desenvolvimento ${ }^{118}$. Pelo contrário tal projeto surgiu nas últimas décadas da configuração sócio-política nascida da industrialização que já se dera. O impulso de desenvolvimento industrial, como projeto, é levado a frente por grupos urbanos que nasceram no processo de industrialização e urbanização que se havia dado como produto indireto da dinâmica da economia exportadora.

5) Os industriais procuram controlar o processo quando:

(...) já existe um Estado atuante, um mercado constituído e quando as outras forças sociais, tanto as massas urbanas e' os grupos médios [burocratas, profissionais, militares, empregados de 'serviços', etc.], juntamente com os grupos oligárquicos e exportadores já estão disputando o aparato do Estado e portanto a possibilidade de influenciar as decisões de inversão e consumo ${ }^{119}$.

\section{${ }^{118}$ Ver FURTADO, 1965, págs. 129-133.}

${ }^{119}$ CARDOSO, 1965 (b), p.11. Para esse autor essa formulação tem ampla generalidade nos países latino-americanos. Essa posição é corroborada pelo artigo de STRASSMANN (1964) sobre o industrial na América Latina. STRASSMANN destaca vários aspectos da organização da empresa e da mentalidade empresarial que encontraremos na caracterizacão, abaixo, dos industriais no Brasil. Citemos alguns trechos entre os mais significativos (págs. 167-168 e 176): "The Latin American industrialist values an enterprise mainly insofar as it is a contribution to family interests, not as an achievement in itself. His first loyalty is to the family (...) A typical result of this family-centered outlook is reluctance to merge with other enterprises even when the separate units are much too small for optimum efficiency". (É consistente com essa colocação, por exemplo, a descrição de STEIN do fracasso da tentativa, em 1930, de se constituir um cartel na indústria têxtil brasileira para se enfrentar a queda do mercado. Ver STEIN, 1957 (b), págs. 129-130.) Nota ainda STRASSMANN, sobre os 
Embora a sua influência sobre a formulação da política econômica e social estatal seja crescente, essa política se configura, de modo característico, como a de um "Estado composto", Responde assim aos interesses de grupos econômicos, que atuam das formas tradicionais ${ }^{120} \mathrm{ou}$ como grupos de pressão sobre a estrutura político-administrativa, respondendo também à presença do "interlocutor afônico" (ou em momentos quase mudo), mencionado por Cardoso, as camadas médias e baixas dos centros urbanos.

Compreende-se os industriais, no que diz respeito à racionalidade econômica enquanto empresários, e à orientação para com a sociedade global, enquanto classe, devido a essa forma de desenvolvimento industrial. Examinemos esses característicos.

A empresa de família é ainda a norma no Brasil ${ }^{121}$; a sua prevalência implica numerosos fatores de irracionalidade da ação econômica, A resistência à delegação de autoridade impede a diferenciação burocrática da administração e dificulta o aproveitamento de técnicos; para manter-se tudo "sob o olhar do dono" perdem-se oportunidades de expansão da empresa; para assegurar-se, aos membros do "clã", seu controle, deixa-se de "abrir" a

industriais latino-americanos, que eles eram homens "who prospered from controls, tariffs, public credit facilities, and government contracts. Originally their chief resources were influence on official decision-making". Decorre das condições concretas em que se dá a industrialização (pela proeminência do papel do Estado e, mais adiante, das empresas estrangeiras) a tendência do empresário para "fechar o mercado" e a ausência que exibe de "espírito de risco".

${ }^{120}$ Ver, abaixo, págs. 164-167.

${ }^{121}$ Em todo esse trecho nos apoiaremos na análise de CARDOSO (1964 (a), 2. ${ }^{\text {a }}$ parte). Sobre a empresa familiar, ver também a caracterização de IANNI, onde o que denomina de "empresa clânica" é concebida como resultado do entrelaçamento de elementos sócio-culturais da ordem patrimonialista no Brasil com outros específicos da ordem capitalista (IANNI, 1963, págs. 37-49). Pertinente também à persistência do padrão de controle familiar da empresa é o resultado de Flávio SAMPAIO em estudo de amostra de noventa e uma empresas, no "Grande São Paulo", com duzentos e cinqüenta empregados ou mais (realizado em 1961-62) e nas quais se sorteava um diretor por empresa para responder o questionário. Escreve o autor: " $73,3 \%$ das empresas visitadas foram rondadas pelos pais ou por parentes do diretor, ou pelo próprio diretor, sós ou com sócios, sendo que 66,7\% deles ainda detêm 51\% (ou mais) do capital da empresa" (SAMPAIO, 1964, p.110). Isto em São Paulo, onde o padrão já está mais enfraquecido que nas outras cidades industriais do país. empresa para a participação acionária do grande público e, portanto, deixase de obter capital na quantidade precisa para enfrentar o acirramento recente da concorrência ${ }^{122}$. Ao padrão do controle familiar dos empreendimentos associa-se, no geral, a mentalidade econômica dos dirigentes e capitães-de-indústria tradicionais. Esta mentalidade surge em duas variantes: ou marcada pelo espírito de aventura e aproveitamento de todas as situações que no meio brasileiro são conducentes à acumulação do capital, situações que dependem em boa dose de medidas governamentais, ou pelo espírito de usura, com a valorização do trabalho e da poupança, e a exploração de condições técnicas precárias e da força de trabalho "até o limite da irracionalidade".

Novos elementos, entretanto, surgem no panorama empresarial brasileiro. Delineia-se em freqüentes casos a quebra do controle familiar do empreendimento e começa a existir uma mentalidade nova, a do homem-deempresa. Este está comprometido com a indústria, visa o lucro a longo prazo através da ação rotineira da empresa num ramo determinado, preocupa-se, numa nova situação competitiva, com a modernização técnica e administrativa da sua companhia e é favorável à participação dos empresários, como "classe produtora", na condução dos problemas do país. Tais mudanças ocorrem quando se inicia a alteração das condições que explicam a persistência dos padrões tradicionais de empresa e de mentalidade econômica. Em suma, aquelas condições são as seguintes: fraca concorrência; níveis altos de lucro mesmo com produção a custos elevados; e, sobretudo, a centralização de decisão ${ }^{123}$ exigida por uma

${ }^{122}$ É esclarecedora a análise de CARDOSO do circulo vicioso constituído pela persistência de práticas financeiras e contábeis tradicionais e pela dificuldade de obtenção de recursos que permitam a racionalização. Permitimo-nos citar um trecho: "Para escapar às injunções fiscais de uma política inadequada à realidade econômica atual, as empresas 'fechadas' lançam mão de expedientes fraudulentos que ‘diluem' na massa do patrimônio, novos equipamentos e instalações. Com essa prática diminuem continuamente as possibilidades da distribuição ampla de ações e de sua transformação efetiva em 'sociedades anônimas'” (1964 (a), págs. 110 e segs.; a citação é da p.113).

123 A relutância em delegar funções, por parte de diretores-proprietários, resulta tanto ou mais da necessidade de decisão rápida na situação em que medidas governamentais são de grande importância e pouco previsíveis, quanto da pura tendência a manter o controle familiar da empresa. Verificamos os mesmos problemas de delegação de atribuições em empresa não-familiar e 
situação em que oportunidades de lucro dependem decisivamente da política governamental (mormente nos campos financeiro, cambial e de regulamentações de importação) e em que industriais têm fraca influência sobre tal política, que é, pois, bastante imprevisível.

Foi o último surto industrial nos anos 50, com a entrada em grande escala de capitais estrangeiros nas indústrias mecânica e pesada, que caracterizou parcialmente uma nova situação. Frente ao nível técnico e métodos modernos de administração e controle das novas empresas, a antiga camada empresarial vê-se ante a opção de modernizar-se ou marginalizar-se. Nesse último caso restringe-se a produtos de padrão baixo para consumidores ainda "marginais" no mercado ${ }^{124}$ ou limita-se a mercados regionais, protegidos da produção das empresas de fora e mais modernas pelos altos custos de transporte. Num e noutro caso, a subsistência da empresa industrial tradicionalizada, sem a modernização, é efêmera ${ }^{125}$. As dificuldades impostas pelos seus padrões tradicionais para a obtenção de capitais e know-how técnico e administrativo significam com freqüência que, para modernizar-se, se faz necessária a associação a grupos estrangeiros ${ }^{126}$.

Cardoso vê os industriais, no seu conjunto, como uma camada recente e heterogênea, com pouca "tradição industrial", sem ter desenvolvido orientação de comportamento por valores compatíveis à situação de classe e tampouco um projeto de industrialização realizável pela obtenção de "hegemonia política". Há, neste último ponto, certa indecisão nas suas formulações. Às vezes salienta a ausência de "projeto de

tecnicamente moderna (com know-how estrangeiro), que estudamos. Ver LOPES, 1964, trecho sobre "Aspectos da organização e da administração da fábrica", págs. 100-114.

${ }^{124}$ Ver, acima, págs. 44-49.

${ }^{125}$ Em estudo de caso de indústria têxtil, em comunidades tradicionais de Minas Gerais, assinalamos como fatores de mudança, além do aluir do mercado regional pelo progresso dos transportes, a perda de vantagens da mão-de-obra barata, com o nivelamento gradual do salário mínimo no país. LOPES, 1967, págs. 76-80. Ver também, abaixo, p.205.

${ }^{126}$ Ocorre ainda o caso de alianças entre grupos familiares. Com isso não se resolve, porém, o problema do know-how. A dificuldade para obter capitais, lançando-se ações amplamente, já foi mencionada acima. dominação política", por parte dos empresários industriais, às vezes menciona o abandono de tal projeto ou o risco de perdê-lo ${ }^{127}$. A nota dominante de sua análise é, entretanto, sublinhar a vacilação dos industriais, como classe. No seu artigo mais recente ${ }^{128}$, tal vacilação é incisivamente associada à "ambigüidade da situação" em que surgem os empresários industriais na América Latina, vinculados desde a origem, como vimos, a políticas de interesse do setor exportador, à emergência das massas urbanas e ao peso destas no processo político.

Os vários fatores responsáveis por esse fraco desenvolvimento dos empresários como classe devem-se, todos, ao modo pelo qual se deu a industrialização. São eles: a dificuldade de ligarem-se entre si setores heterogêneos dos industriais; a não-necessidade de enfrentarem uma classe operária aguerrida, e os altos lucros obtidos com as práticas tradicionais, ao nível da empresa, e com a manipulação, por meio de teia de relações informais, dos favores e medidas governamentais.

Durante o desenvolvimento industrial, mormente se olhado no seu longo curso desde os meados do século passado, juntaram-se ao grupo de industriais, nos vários momentos, pessoas de variada extração étnica e social. Ao lado de elementos de origem imigrante encontramos frações das antigas camadas senhoriais. Stein aponta que na indústria têxtil (o nosso principal ramo até 1930) um grupo nacional foi suplantado por importadores portugueses, aos quais, depois de 1914, juntaram-se, particularmente em São Paulo, imigrantes e seus descendentes ${ }^{129}$. Pesquisa realizada por Bresser Pereira em São Paulo, sobre a origem étnica e social dos iniciadores da "revolução industrial brasileira", na expressão do autor, fornece-nos dados relevantes. Da amostra dos empresários, 49 por cento eram imigrantes, outros 35 por cento eram filhos ou netos de imigrantes e 16 por cento eram brasileiros de pelo menos três gerações. Esse último

${ }^{127}$ Ver, por exemplo, os trechos nas págs. 176 e 178 (CARDOSO, 1964 (a). Note-se também a afirmação de STRASSMANN no sentido de que "as a power structure, industry is a loose federation of intensely self-interesled clans" (STRASSMANN, 1964, p.176)

1281965 (b), págs. 12-13.

${ }^{129}$ Apud STRASSMANN, 1964, p.164. 
grupo provinha dos setores da antiga camada superior ou a ela vinculada (grandes fazendeiros ou exportadores, profissionais liberais, etc.), os outros dois das camadas de comerciantes, industriais ou de ocupações manuais ${ }^{130}$. Tal diversidade de origens, associada à retenção de perspectivas e traços culturais particulares de cada grupo étnico-social, dificulta a união dos industriais numa mesma consciência e ação ${ }^{131}$.

Trataremos mais adiante, mas ainda nesta secção, do operariado industrial. Aqui, basta mencionar que o seu estudo, de fato, leva-nos a salientar o pouco desenvolvimento entre eles de formas de consciência e ação características de classe operária; apresentam pelo contrário comportamento de massa, indistinto dos de outros componentes das massas urbanas.

Quanto ao terceiro ponto - a persistência entre os industriais de formas tradicionais de manipulação da estrutura de poder - vale a pena nos referirmos à pesquisa pela qual Leeds ${ }^{132}$, por meio de entrevistas com pessoas proeminentes da organização social brasileira, identificou, entre as unidades estruturais informais, básicas daquela organização, a "panelinha político-econômica", que entrelaçaria os mundos político-administrativo e econômico e, no primeiro, os seus vários níveis, municipal, estadual e federal. Uma citação, embora longa, será útil.

\footnotetext{
${ }^{130}$ O trabalho de Luís Carlos Bresser PEREIRA levantou dados sobre o fundador da empresa, ou o principal responsável pela sua expansão, fosse ele vivo ou já falecido. Abrangeu amostra probabilística, num total de duzentas e quatro, das empresas do "Grande São Paulo" com cem empregados ou mais. Procurava-se assim obter a origem social e étnica dos que deram inicio à revolução industrial no Brasil, ocorrida principalmente depois de 1930. Dos incluídos no levantamento, 83 por cento haviam iniciado $\mathrm{O}$ empreendimento e o restante apenas o expandira. Ver L. C. B. PEREIRA, 1964

${ }^{131}$ É significativa, no caso relatado por STEIN das dificuldades em se organizar o cartel da indústria têxtil em 1930, a citação que faz de carta de porta-voz daquela indústria: "As nossas fábricas pertencem a pessoas de diferentes raças que não se unem face ao perigo comum. $\mathrm{O}$ sírio olha a situação de uma maneira, o italiano tem o seu ponto de vista sui generis e assim por diante". STEIN, 1957 (b), p.130. Sobre a situação no presente, ver CARDOSO, 1964 (a), págs. 160 e segs.

${ }^{132}$ LEEDS, 1964. As entrevistas foram realizadas em São Paulo, Rio, Belo Horizonte, Recife, Salvador e Brasília.
}

A panelinha político-econômica consiste caracteristicamente em um funcionário de alfândega, uma pessoa do ramo dos seguros, um ou dois advogados, homens de negócio, um contador, um deputado municipal, estadual ou federal, e um banqueiro com seu banco. Não há acordo formal entre essas pessoas; não há reuniões. Elas são identificáveis apenas pelos relatos dos participantes e por observação do comportamento associativo dos indivíduos em questão, em diversos contextos e durante longos períodos de tempo ${ }^{133}$.

Esta unidade estrutural é inteligentemente relacionada nesse artigo a outros fenômenos da rede de relações informais, tais como o preenchimento pela mesma pessoa de múltiplos cargos ("cabide de emprego"), o "pistolão", o uso de posições-chaves para avançar na carreira ("os trampolins"), a estrutura de parentesco e compadrio, o funcionamento dos meios modernos de comunicação para a "projeção" de indivíduos, etc.

Essa análise nos sugere uma das maneiras pelas quais, nas camadas médias e superiores, setores "tradicionais" da sociedade entrelaçam-se com os modernizados. Depois de apontar como as "panelinhas" se encadeiam até alcançar o topo da estrutura social, Leeds acrescenta:

As panelinhas, todavia, não estão completamente na dependência do Presidente ou de outras altas autoridades, uma vez que esses, por seu turno, precisam das panelinhas que ajudaram, para a obtenção de favores em troca. Isso é especialmente verdadeiro no que diz respeito ao apoio político no nível local em eleições ou para tornar efetiva a política decidida (policy decisions) no nível superior, nos organismos políticos estaduais e municipais. Alienar panelinhas não é boa política (p.1.337).

Participando de um mundo altamente personalizado ${ }^{134}$, os industriais tenderiam a resolver os problemas de sua companhia, freqüentemente para

${ }^{133}$ Ibidem, p.1.336. Noutro trecho o mesmo autor define a "panelinha" como "a relatively closed, completely informal primary group, held together in common interest by ties of friendship or other personal contact acting for common ends and including a roster of all key socio-politico-economic positions" (p.1.330).

${ }^{134}$ Não se trata, parece-nos, apenas de sobrevivência do patrimonialismo, mas de sua reestruturação como parte de uma organização social mais ampla e complexa. 
"fechar o mercado", usando para tanto os seus deputados ${ }^{135}$ ou, talvez, mais comumente, atuando simultaneamente sobre vários pontos, através de estruturas como as estudadas por Leeds, nos meios de comunicação, na máquina político-administrativa, e nas suas associações de classe ${ }^{136}$. Setores do empresariado unem-se, às vezes, para reivindicar medidas de interesse de um ramo. A monografia de Stein traz-nos vários casos em que os empresários da indústria têxtil, em conjunto ou, o mais das vezes, seccionalmente, defendendo através das associações os interesses das maiores empresas do Centro-sul, pressionaram o Governo para obter as medidas que reivindicavam. Foi o caso da campanha pela elevação de tarifas em 1928-29; o da pressão, na década dos anos 30, de industriais do Rio e São Paulo pela proibição, e depois pela prorrogação dessa proibição, de importação de equipamentos e máquinas têxteis; o da defesa do mercado do Centro-sul, por ocasião da elevação do salário mínimo em 1943, contra a sua invasão pelo tecido do Nordeste produzido com mão-de-obra mais barata, para citar apenas alguns dos exemplos melhor documentados ${ }^{137}$.

135 Ver o que diz SINGER (1965) a respeito dos representantes nos legislativos de grupos econômicos. Esse autor do enfrenta, porém, o problema da generalidade dos interesses defendidos, se de uma empresa, de um ramo ou da indústria, ou ainda da propriedade. Terem as empresas deputados seus, é fenômeno distinto por exemplo da generalização do interesse industrial, que se operou no selo de uma National Association of Manufacturers. Sobre este último ponto, consultar BRADY, 1943.

${ }^{136}$ CARDOSO, 1964 (a), págs. 163-164.

137 Ver STEIN, 1957 (b), págs. 126-128 e 140-161. Neste último trecho, acha-se amplamente documentada a luta de Interesses entre as maiores indústrias têxteis do Rio e de São Paulo, e as doutras partes do país, a respeito da proibição de importação de maquinaria. Nota STEIN a certa altura: "(...) curtailment of machinery Imports caused friction among entrepreneurs since it froze the relative positions of the large urban mills with respect to the small establishments of the interior" (p.143). Quanto ao caso do salário mínimo em 1942-43, documento do Sindicato da Indústria Têxtil de São Paulo fornece-nos dados valiosos. Nele se propugna a diminuição dos desníveis dos mínimos salariais nas várias partes do país, pois os que existem "[fomentam] uma franca concorrência desleal" pelos industriais do Nordeste. Chega o documento até a argumentar pela imediata decretação do mínimo (com a diminuição dos desníveis), em vista das "grandes dificuldades" que, se não, atravessaria a classe operária; ajunta ainda ser necessária a elevação do poder aquisitivo dos operários para a "absorção da torrente de produtos de soas atividades". Sindicato da Indústria de Fiação e Tecelagem em Geral, São Paulo, 1942, págs. 21-23.
Raramente os industriais, desses ou de outros ramos, vêem os problemas, ou ainda menos agem de modo concertado em função de problemas da Indústria ou da Economia Nacional.

As condições responsáveis pela natureza do empresariado, no nível da empresa e no da sociedade são, em síntese: a sua origem pré-industrial recente; a sua heterogeneidade; os laços (derivados da origem social comum e do entrelaçamento de interesses econômicos) de certos de seus setores com os das antigas camadas altas da agricultura e comércio de exportação; a conjuntura de altos lucros durante boa parte do período de sua gênese; a constante importância para essa conjuntura dos favores e medidas do Governo; o operariado presente como massa no processo político porém pouco agressivo como classe. Todas essas condições ligam-se às formas pelas quais se deu a industrialização do Brasil.

Podemos concordar, pois, grosso modo, com as conclusões de Cardoso no sentido de que

(...) as condições sociais de formação da burguesia industrial exercem um "feito de amortecimento" na concretização das possibilidades de consciência dos interesses de classe que a camada industrial virtualmente possui e dificultam o desenvolvimento de formas de comportamento social compatíveis com sua "situação de classe" ${ }^{138}$.

${ }^{138}$ CARDOSO, 1964 (a), p.166. São apropriadas algumas observações acerca desta conclusão de F. H. CARDOSO de não terem os industriais desenvolvido, baseados na sua "situação de classe", uma consciência e ação diferenciadas das da antiga camada latifundiária-mercantil. Parece-nos que o autor mostra não tanto um "amortecimento" da consciência de interesses de classe da burguesia industrial, como mostra a existência de condições (ligações com as antigas camadas, presença da massa urbana) que the dificultam concretizar o seu projeto de classe e empolgar o aparelho do Estado. Quanto a esse ponto, o próprio autor em escrito mais recente formula melhor a questão: "Ademas los grupos empresariales se encuentram limitados en cuanto a las opciones que pueden hacer por la ambiguiedad de la situación en que surgen: o bien se asocian a las masas para presionar al Estado en contra a los grupos exportadores, o bien temen el posible desplazamiento de sus chances de control politico social por la acción de las masas (...)” (1965 (a), p.12). Perceber-se-ia melhor, talvez, o desenvolvimento de um projeto da camada empresarial, no plano da sociedade, se se focalizasse, mais diretamente do que o fez CARDOSO, a ação organizada, dos industriais e, também, se se analisasse as políticas econômicas e sociais do Governo, indagando-se a que interesses atendem. 
Entretanto, embora de modo hesitante (como acontece em geral com todos os fenômenos históricos apreendidos no seu fluir), pode-se vislumbrar o aumento da racionalidade da ação empresarial no âmbito da empresa (é o que os dados sobre a burocratização da indústria nos levaram a concluir) e a emergência do projeto, entre os industriais enquanto classe, da implantação da ordem competitiva capitalista no Brasil. Ambos processos são marcados pelas formas concretas com que se industrializa e urbaniza o país, formas que produzem ao mesmo tempo os industriais, as novas classes médias e o operariado. Vimos atrás como os comportamentos desses protagonistas entrosam-se, marcando o do primeiro. Focalizemos agora a nossa atenção diretamente naqueles dois últimos.

Não há estudo geral sobre as camadas médias no Brasil. Podemos, todavia, lançar mão, para sublinhar sucintamente alguns dos seus caracteres mais evidentes e, talvez, mais importantes, de observações e pesquisas esparsas, essas últimas o mais das vezes feitas com outros objetivos. Delas ressalta o caráter urbano da classe média, o seu recente e rápido crescimento, a sua heterogeneidade (abrangendo setores antigos e novos e de diversa origem étnica e social) e a sua diferenciação conforme as regiões do país.

Trata-se de camada urbana recente na estrutura social. (Dada a alta concentração da propriedade da terra, com a exceção de em algumas poucas áreas nas zonas de colonização dos Estados sulinos e, talvez, incipientemente em São Paulo, os pequenos proprietários rurais não constituem uma classe média rural no Brasil. Assimilam-se, no caso dos minifundiários, aos lavradores sem terra; no caso dos sitiantes um pouco maiores - porção em geral diminuta da população rural - trata-se em geral

Deve-se notar que, colocando-se de perspectivas como essas, autores como IANNI (1965, págs. $97-$ 129) e SINGER (1965) chegam, quanto ao problema, a posições bem distintas da de CARDOSO. Seriam também pertinentes à questão problemas tais como o do entrelaçamento de interesses, realmente existente, do empresariado industrial com os de grupos agrários e exportadores; o do grau de transformação do latifúndio em empresa capitalista; e do processo pelo qual o "nacionalismo" se transformou em "desenvolvimentismo" (promovendo o influxo maciço de capitais estrangeiros na indústria) de partes em decadência da classe rural alta ${ }^{139}$.) As camadas médias prendem-se assim à urbanização, às várias ondas crescentes em que esta se dá no Brasil, e no período mais recente, basicamente, ao processo de burocratização $^{140}$, tanto no setor público como no privado. As formas concretas do desenvolvimento brasileiro tornam essa camada heterogênea, diferenciam-na segundo as várias partes do país e marcam o seu modo de ser. A urbanização que já se dera nos fins do século XIX e princípios do atual causou o aparecimento de seus setores mais antigos, ainda que de modestas proporções: os funcionários mais graduados do Governo nos seus vários níveis, nas grandes cidades e nas provincianas, os profissionais liberais, professores, militares, pequenos comerciantes e artesãos. A sua origem étnica e social, já então, começa a diferenciar-se regionalmente. Em todo o Brasil forma-se a camada média com elementos que se desprendem da camada senhorial e mercantil. No Sul, porém a esses elementos juntaram-se os de extração imigrante e de origem humilde ${ }^{141}$.

A forma pela qual se deu desde então o desenvolvimento - com a crescente participação do setor público, o crescimento das grandes empresas burocratizadas e, sobretudo, a progressiva concentração geográfica da industrialização no Centro-sul - explica a enorme expansão e a natureza dos novos setores da classe média. O fenômeno, embora não tenha sido aquilatado diretamente, é evidenciado pelo crescimento da educação secundária e superior, pelo aumento dos que pagam imposto de renda, pela circulação cada vez mais ampla de revistas 'de certos tipos, e, mesmo, pela expansão de certas facilidades urbanas, tais como o telefone ${ }^{142}$.

${ }^{139}$ Para uma visão geral do assunto, ver PRADO JR. (1960); as afirmativas do texto são também corroboradas pelo estudo da estratificação social rural Leopoldina realizado por Oracy NOGUEIRA (s/d; manuscrito). Sobre a situação em São Paulo, ver MONBEIG (1952).

${ }^{140}$ Ver, acima, págs. 102-120.

${ }^{141}$ Ver o artigo recente de BASTIDE (s/d) para uma boa exposição, embora concisa, da formação histórica das camadas médias no Brasil A pesquisa de CASTALDI (1960) sobre a ascensão social de grupo de origem italiana na cidade de São Paulo é também relevante para o tema.

${ }^{142}$ Ver BASTIDE, s/d, págs. 7-10 e WAGLEY, 1963, págs. 122-127. SINGER, 1963 (a), em análise estatística cuidadosa, com base em várias fontes. (o censo, parece, superestima as pessoas que possuem curso médio), calcula o aumento dessas pessoas, no Brasil, entre 1940 e 1950, em 151 por cento. As diferenças regionais na difusão da educação secundária são grandes. Relacionando-se as 
O funcionário público, o bancário, o comerciário, o empregado de escritório e técnicos de toda a espécie, são, aqui como em outros países ${ }^{143}$, as personagens características das novas classes médias.

Ademais, aquele mesmo processo de desenvolvimento, geograficamente concentrado, leva a uma diminuição relativa dos antigos setores médios, ao passo que amplia os novos, sentindo-se serem uma e outra tendência proporcionalmente maiores na região dinâmica, o Centrosul, do que no resto do país ${ }^{144}$.

Assim, o ritmo da formação das camadas médias como um todo é certamente mais acelerado nas cidades do Centro-sul do que nas restantes. Também, em umas e outras regiões é diversa a sua composição, seja ocupacionalmente (com maior participação no Centro-sul de ocupações ligadas a empresas e órgãos públicos racionalizados), seja quanto a origem étnica e social (maior proporção talvez de pessoas em ascensão social naquela região e certamente dos de origem imigrante; e menor dos originados das classes altas locais dos pequenos centros urbanos do interior $\left.{ }^{145}\right)$.

É difícil perceber - dada a ausência de dados e pesquisas - até que ponto tais diferenças de origem e composição sociais diferenciam por sua vez, regionalmente, o modo de ser da classe média. Há, em todo o caso, a nosso ver, uma situação comum para essa classe em todo o país, responsável por fenômenos também comuns, relativos a suas atitudes e ação. São os seguintes os componentes daquela situação comum. De um lado, a heterogeneidade da camada, seja ela maior ou menor; do outro, a

matrículas em todos os tipos de escolas secundárias à população de 11 a 18 anos, encontramos para 1958 no Sul e no Nordeste, respectivamente, a taxa mais alta e a mais baixa: 14,6 e 6,5 por cento (MOREIRA, 1960)

${ }^{143}$ Ver, por exemplo, MILLS, 1953. Num outro trabalho, apresentamos um sumário a esse respeito (LOPES, 1964, págs. 175-176)

${ }^{144}$ Ver o interessante estudo de DI TELLA (1964, págs. 8-13) sobre esse ponto para o Brasil, em que analisa dados censitários por Estado.

${ }^{145}$ Os dados de B. HUTCHINSON sobre a hierarquia ocupacional e a sua mudança no curso de uma geração, para São Paulo e várias outras cidades do Centro-sul, são relevantes (1958, manuscrito; 1960 , p.211 e 1963, p.68). influência uniformizadora (mas não diferenciadora dela como classe) do sistema educativo, dos meios de comunicação de massa, de uma situação econômica, em traços gerais, comum (derivada da sua inserção no processo de desenvolvimento que se faz com a inflação) e da prevalência nessa classe de valores e perspectivas derivados da classe alta tradicional ${ }^{146}$, (Quanto a esse último fato, convém notar ser ele devido à persistência cultural de tal orientação entre os setores da camada média que se originaram na classe alta tradicional e a ela ainda se ligam por laços de família e às vezes por convívio social; explica-se, talvez, por outro lado, pelo fato mesmo da mobilidade, a permeação por aqueles traços culturais dos outros componentes das camadas médias, daqueles que ascenderam socialmente.)

Disto tudo - condições todas vinculadas às formas pelas quais se formaram as camadas médias e à rapidez do processo - resulta a posição sócio-política conservadora dos seus membros, o uso que fazem das teias tradicionais de influência política (as "panelinhas" de que já tratamos e das quais eles participam, quaisquer que sejam as suas origens sociais), e a sua ação política, guiada pelo moralismo entre eles prevalecente e manipulada em larga medida por liderança carismática, em fenômeno equivalente ao populismo. Resulta, portanto, de todas aquelas condições não desenvolverse nas camadas médias consciência e ação comuns próprias. Noutras palavras, no plano político, a ação de seus membros não é de classe, mas de $\operatorname{massa}^{147}$.

Fatores similares a esses são reencontrados ao nos voltarmos, agora, para a situação e o comportamento operários. É também o processo social de formação do operariado industrial e a sua situação atual que explicam o seu comportamento, o não se constituírem entre eles perspectivas e orientações próprias, e, pelo contrário, eles se indiferenciarem numa camada mais ampla e amorfa, como "trabalhadores", "pobres", ou "gente

\footnotetext{
${ }^{146}$ Ver, adiante, págs. 176 e segs. Sobre valores relativos a ocupações que corroboram as afirmativas do texto, Ver LOPES 1960

${ }^{147}$ Cf. SOARES, 1965 e BASTIDE, s/d.
} 
do povo"; explicam igualmente a fraqueza de sua ação sindical e a política de massa que sobre eles se assenta ${ }^{148}$.

Numa primeira fase, que se prolonga até o começo dos anos 30, a não-constituição de consciência e ação como classe, entre os trabalhadores industriais de pequenas oficinas e indústrias acanhadas, deriva, segundo $\mathrm{F}$. H. Cardoso, da descontinuidade da industrialização; da preponderância do motivo de ascensão social entre operários imigrantes, vindos no geral de áreas rurais da Europa; e, sobretudo, da sua inserção numa sociedade tradicional e agrícola, em que "o sistema institucional do poder e os mecanismos básicos de controle social sancionavam a dominação de cunho patrimonial-estatal, exercida pelos grandes proprietários e exportadores". Surgiram naquela época movimentos grevistas, débeis, porém, às vezes violentos, liderados por aqueles imigrantes que traziam da Europa experiência industrial e idéias anarquistas, anarco-sindicalistas, sindicalistas e outras, idéias essas lá então prevalecentes. Devido, porém, às próprias condições de formação do operariado restrito, ao qual era recusada participação própria no corpo social, "a ação operária estava condenada a ser, ao mesmo tempo e ambiguamente, violenta e impotente" ${ }^{\text {"149. }}$.

O operariado brasileiro de hoje é, grosso modo, produto dos últimos decênios. Forma-se no contexto concreto do modo pelo qual se dá, nesta fase, o desenvolvimento. A industrialização, como vimos, ganha em continuidade e se intensifica; o mercado nacional constitui-se e, pela

\footnotetext{
148 Ver as pesquisas do autor (LOPES, 1964 e 1967). Neste trecho do trabalho, colocamos as questões sobre o comportamento operário, como surgem naquelas pesquisas, no contexto geral do processo de formação da camada e da sua situação atual. Para isso usamos também os livros e artigos de TOURAINE, 1961, A. SIMÃO, 1961, F. H. CARDOSO, 1961 e L. RODRIGUES, 1966.

${ }^{149}$ CARDOSO, 1961, págs. 55 e 59. É especialmente esclarecedora a análise que apresenta de duas greves dos começos do industrialismo brasileiro, a de uma estrada de ferro, em 1884 (em que, por exemplo, os empregados se dirigiram aos patrões com os termos: "À digna diretoria levamos os nossos queixumes (...)” (p.57)) e, em 1896, a da fábrica de chapéus João Adolpho. Há um paralelo bem próximo entre as relações de trabalho em São Paulo e no Rio na fase anterior a 1930 e as prevalecentes, ainda hoje, em comunidades industriais, tradicionalizadas, do interior. (Ver LOPES, 1964.) Sobre o período em pauta, ver também L. RODRIGUES, 1966, págs. 103-156. Sublinha esse último autor a instabilidade e a fraqueza do movimento sindical daquela época.
}

predominância do Centro-sul, provoca movimentos inter-regionais de população; o Estado, respondendo tanto à necessidade de controle da massa trabalhadora quanto à nova configuração do poder que se delineia durante o período, com a presença cada vez mais visível na sociedade de largas camadas urbanas, operárias e de classe média, passa a interferir nos problemas trabalhistas, estabelecendo legislação do trabalho e de previdência social e constituindo organização sindical de cunho corporativista; um projeto de industrialização forma-se num movimento social guiado por setores médios, com a participação de massas populares e que penetra pouco a pouco no meio empresarial (transformando, no processo, o "nacionalismo" em "desenvolvimentismo"); empresas modernizadas' surgem no parque industrial do Centro-sul e, exigindo a sua tecnologia trabalho semiqualificado, passam a atrair mão-de-obra de origem rural e semi-rural ${ }^{150}$.

As condições determinantes da natureza do operariado no Brasil atual são, portanto, as seguintes:

1. A entrada maciça de trabalhadores de origem rural recente nos centros industriais mais importantes do país ${ }^{151}$;

2. O fato de o ingresso desses elementos na indústria fazer parte de uma conduta de mobilidade, sendo o emprego fabril, muita vez, uma mera etapa dessa mobilidade (e quase sempre o sendo, no sentido subjetivo);

3. O usufruto de uma estrutura jurídica que dá direitos aos trabalhadores urbanos (sejam eles industriais ou não); nesse sentido, mesmo que a posição econômica do operário ficasse estabilizada nesse período - o que não ocorre, pois ela melhora ${ }^{152}$ - tais direitos representam em si, para aquele trabalhador, clara ascensão sócio-econômica relativa ao status que tinha no meio rural ou semi-rural de origem;

${ }^{150}$ Cf. TOURAINE, 1961 e F. H. CARDOSO, 1961 e 1964 (a).

${ }^{151}$ Os dados de A. SIMÃO (1961, p.73), embora se refiram a associados de sindicato, são pertinentes. Em 1936-40, 5 por cento dos associados do sindicato dos metalúrgicos de São Paulo eram provenientes de outros Estados; em 1956-60 essa porcentagem atingia 38 por cento.

${ }^{152}$ Entre 1940 e 1960, o índice do salário real no Rio subiu de 79 para 135 (Desenvolvimento \&: Conjuntura, 1961, pág, 75, apud IANNI, 1965, p.163). 
4. A sua participação no meio urbano da democracia de massa, através das lideranças populistas e das máquinas eleitorais urbanas. Esta participação, convém notar, faz-se em dois planos distintos, no do projeto de desenvolvimento nacional e no das vantagens concretas, distribuídas através da rede de políticos e cabos eleitorais da "demagogia urbana" (rede que é espécie de estrutura substituta dos laços com os coronéis e chefes políticos provincianos, deixados para trás por aquele trabalhador) ${ }^{153}$.

Em síntese, concordamos com a observação de Touraine de que a "democracia de massa, consumo de massa (ou pelo menos espetáculos de massa) e nacionalismo reforçam o sentimento de pertencer à sociedade nacional" 154 e que este é um fato básico para se compreender o comportamento do operariado das grandes aglomerações industriais brasileiras. Nestas aglomerações, o personagem central é o trabalhador não e semiqualificado com um passado rural recente. (O operário qualificado representante dos velhos núcleos operários do passado - com experiência urbano-industrial mais longa, freqüentemente de origem estrangeira, distingue-se e se separa, econômica e socialmente, bem como pela sua ação, da massa pouco qualificada que o rodeia ${ }^{155}$ ).

Compreende-se a ação dos componentes dessa massa operária dentro do contexto da situação constituída naquele processo. O comportamento do trabalhador de origem rural é movido, antes de tudo, pelos seus fins individuais, entre os quais se destaca o desejo de ocupação independente. Ademais, para a consecução desse desejo - com as numerosas oportunidades existentes para isso na grande cidade, - usa o próprio emprego fabril, a legislação trabalhista e o sindicato. O seu comportamento coletivo é pouco desenvolvido e frágil, tanto dentro da empresa, onde praticamente inexistem agrupamentos e controle social informais, quanto fora dela. Forma-se entre eles apenas tênue solidariedade aos companheiros de trabalho (correlativa à difusa, vaga e, o mais das vezes, latente

${ }^{153}$ Ver, acima, págs. 95-96.

154 1961, pág., 86.

${ }^{155}$ Sobre o trabalhador qualificado ver LOPES. 1964, págs, 83-93. hostilidade para com os chefes e patrões); não é de forma alguma consciência de classe. Nessas condições a sua participação em greves ou em outros movimentos coletivos é débil e pouco duradoura, baseando-se em parte nesta solidariedade, mas sobretudo na capacidade de organização de greves pelo sindicato. Este para isso insere-se no jogo de poder de grupos políticos, e do modo pelo qual isto se realiza depende, entre outras coisas, o grau de repressão policial, fator principal do sucesso ou fracasso das greves $^{156}$.

É ainda fundamental notar que aquele sentimento de solidariedade do operariado (para cuja caracterização nos permitimos utilizar um nosso trabalho anterior) abrange:

o [grupo] dos "trabalhadores", símbolo impreciso que não inclui apenas os operários, mas os "pobres", os que precisam de "trabalhar de dia para comer de noite", O que está surgindo entre esses operários de origem rural não é ainda" a consciência de serem indivíduos numa situação nova (a de trabalhador industrial), que os distingue da de outros grupos da população, mas sim um sentimento de revolta da classe baixa (pobres, povo) contra as classes superiores, que não distingue operários, pessoas em ocupações modestas e meeiros, camaradas, pequenos sitiantes, no campo. Sentimento do qual podem participar, portanto, pessoas que (...) não estão completamente integradas, nem subjetiva, nem objetivamente, no meio industrial, mas que alternam ocupações agrícolas, comerciais e industriais, de classe baixa ${ }^{157}$.

Em suma, não é solidariedade de classe, mas sim sentimento de origem estamental, em transformação no cadinho do meio urbano, onde passa a constituir a base social para o tipo de ação sindical que ocorre e para a política populista.

Na medida em que se estabilizar a condição do operário industrial é de se esperar, pressupondo-se a sua continuada participação na sociedade de massa, maior fundamentação psicossocial de sua ação coletiva, declínio do

\footnotetext{
${ }^{156}$ Ver estudo de Leôncio RODRIGUES sobre greves em São Paulo (1966, págs. 49-100).

${ }^{157}$ LOPES, 1964, págs. 67-68.
} 
controle estatal sobre os sindicatos, e desenvolvimento no sindicalismo, talvez, de um "reformismo contratual" 158 . Tendências nesse sentido são perceptíveis na última década. Tais problemas recaem, porém, na questão maior da continuidade do desenvolvimento.

Nesta secção foi visto como, no desenvolvimento urbano-industrial que "o desencontro de intenções" provocara, forjam-se os industriais, as novas classes médias e o operariado, o seu modo de ser e comportar-se; do entrecruzamento de sua ação (junto com a influência da política de massa) surge o projeto de industrialização; do desenrolar da ação desses protagonistas depende o continuar do desenvolvimento e o fazer da história ${ }^{159}$.

Precisamos agora dar mais atenção a um aspecto da sociedade urbano-industrial em formação, já várias vezes mencionado, o da influência abrangente dos meios de comunicação de massa, sobretudo sobre as atitudes e valores sociais. Através dessa influência, vem-se integrando a sociedade nacional e quebrando-se o localismo tradicional.

\section{Contatos, comunicações e valores}

Com o desenvolvimento sócio-econômico entram em mudança os valores vigentes na sociedade. $O$ estudo que fizemos de secularização e individualização, abordando especificamente as novas formas de religião e de família, implicava, é claro, fenômenos de transformação de valores. Neste ponto, porém, pretendemos tratar diretamente essa área, colocando o problema no contexto do incremento de contatos e comunicações na sociedade brasileira, vale dizer, tratar de fatos presos ao processo global de mudança, em curso.

De fato, as migrações internas, mormente as inter-regionais, e as comunicações de massa, pela imprensa, rádio, cinema e televisão, derivam

\footnotetext{
${ }^{158}$ Ver as considerações de TOURAINE (1961, págs. 89-92) sobre as tendências do sindicalismo brasileiro e, especialmente, sobre as alternativas que, segundo ele, se abrem para esse sindicalismo, de desenvolver-se no sentido de um "reformismo legal" ou de um "reformismo contratual".

${ }^{159}$ Cf. F. H. CARDOSO, 1964 (a) e 1965 (b)
}

da civilização industrial entre nós e são, hoje, os meios principais pelos quais as populações se põem em contato e se filtra pelo Brasil a fora a cultura urbana das grandes cidades. A esses meios, deve-se juntar o estabelecimento de um sistema de educação de massa, num duplo sentido. Primeiro porque, como será apontado logo depois, a escola primária é em si, em maior ou menor grau, agente de urbanização, ao colocar professores portadores de cultura urbana em contato com a massa de crianças rurais e semi-rurais. Em segundo lugar, porque as torna, ao alfabetizá-las e transmitir-lhes certas atitudes e valores urbanos, mais suscetíveis de virem a sofrer os efeitos de outros veículos de contato e comunicações, como a imprensa, livros, cinema e mesmo a migração.

Migrações, meios de comunicação de massa, e sistema nacional de educação, todos são fenômenos, convém repetir, da sociedade urbanoindustrial em formação, vinculados aos seus aspectos econômicos, sociais e políticos. Das migrações já tratamos ${ }^{160}$. Basta adicionar uma observação. São distintos nos seus efeitos os movimentos de população dos últimos decênios, da perene movimentação do nosso caboclo, derivada do caráter itinerante da sua agricultura; diferem mesmo dos movimentos que eram provocados pela seca até os anos 20, quando esta levava os flagelados, no máximo, a procurarem as cidades da região ou, saindo desta, a Amazônia. Num caso como no outro, eram colocadas em contato populações não muito diferentes, mesmo quando o retirante ia, por aquele período, para o Recife. Hoje, pelo contrário, o contínuo movimento migratório do Nordeste para o Sul, põe o nordestino no centro da civilização industrial, na sua forma mais desenvolvida no país. Assinalamos atrás os efeitos do movimento migratório na introdução de novos produtos e padrões de consumo, originados pelo contínuo refluxo de migrantes, pelas cartas ou por relatos orais. Difundem-se assim, também, novos valores e idéias. Ocorre, pela emigração, juntamente com outras causas, lenta, persistente e inexorável mudança na velha sociedade nordestina. Não é a única maneira pela qual aquele fenômeno atua na transformação social da área. Aí também, como vimos, os atuais movimentos de população' somam-se a profundo

\footnotetext{
${ }^{160}$ Ver, acima, págs. 56-74.
} 
desequilíbrio sócio-econômico, condicionante talvez das alterações e desorganização da família rústica e dos movimentos religiosos messiânicos ${ }^{161}$.

A constituição de uma rede de educação primária - ainda hoje incompleta - vincula-se à transformação global da sociedade brasileira, nos seus ângulos econômico, social e político. Na sociedade imperial, de grande propriedade e escravocrata, aquela rede praticamente inexistia. Para os filhos dos senhores de engenho e dos fazendeiros de café, a educação era ministrada na Casagrande e depois nos liceus, ateneus e faculdades superiores que com o tempo surgiram. Em trabalho anterior assinalamos a lenta difusão da escola primária. Transcrevamos alguns dados.

Em 1871, quando o Brasil apresentava uma população total de mais ou menos dez milhões de habitantes, havia apenas 147.621 alunos matriculados nas escolas primárias e 9.389 nas secundárias. $\mathrm{O}$ índice de matrículas no curso primário representava, então, 6,1 por cento dos 2.446 .728 de crianças de 5 a 14 anos que havia na época (...) Somente ao redor do início do século começou a educação primária a se difundir entre nós: em 1890 o índice de matrículas era quase o mesmo de vinte anos antes: 6,8 (...) mas, em 1920, já havia subido para 14,7 por cento. Dessa data em diante o aumento daquele índice tem sido constante: 29,8 por cento em 1940 e 38,8 por cento em $1950^{162}$.

Ainda hoje a rede escolar não abrange toda a população a que se destina. Tomando-se agora o grupo de idade mais apropriado, o de 7 a 11 anos, nas zonas urbanas cerca de 80 por cento freqüentavam escolas, segundo o censo escolar de 1964; para as rurais essa proporção atingia pouco mais da metade.

${ }^{161}$ Ver, acima, págs. 127-131 e 141-145.

${ }^{162}$ LOPES, 1959, págs. 61 e 62 . O grupo de idade 5 a 14 anos não é o mais indicado para o cálculo do índice das matriculas. Utilizamo-lo naquele trabalho para tomar comparáveis os dados de que se dispunha entre 1870 e 1950
No momento, o aspecto da escola primária que nos interessa é o de ser ela poderoso agente de urbanização. Luiz Pereira destaca com propriedade esse ponto ${ }^{163}$ :

A análise [do] conteúdo cultural da atividade ensino-aprendizagem [no nível primário] mostra ser ele parte do patrimônio cultural de camadas citadinas sócio-econômicas não-inferiores e evidencia a ligação estreita desse conteúdo cultural com um estilo urbano de vida, possuído principalmente por tais camadas. A transmissão desse. conteúdo (...) atua, nas comunidades rurais e semi-rurais, como agência de desintegração de um estilo não-urbano de vida e, ao mesmo tempo, como agência de urbanização.

A mesma função, acrescenta, é desempenhada pela escola no meio das camadas inferiores urbanas, onde, devido ao êxodo rural urbano, permanecem "muitos complexos da cultura rústica". ${ }^{164}$

Sob tal ângulo, verificar-se quão abrangente é a escola primária nas várias partes do país e quão profunda é a sua ação, medidas uma e outra coisa pela porcentagem da população em idade escolar que frequienta a escola, pelas proporções de repetência, de conclusões de curso e de regentes de classe com formação apenas primária - significa aquilatar a intensidade daquela ação urbanizadora e a sua incidência diferencial na estrutura sócioeconômica brasileira. Os quadros XXVIII e XXIX fornecem-nos essas informações.

${ }^{163}$ PEREIRA, 1960 (b), págs. 57-61 (a citação é das págs. 57-58). As observações de SILVERT e BONILLA, sobre o assunto, são no mesmo sentido (SILVERT e BONILLA, 1961, págs. 20-23).

${ }^{164}$ Funções, nesse sentido, são evidenciadas pelo mesmo autor numa pesquisa de uma escola primária na zona metropolitana de São Paulo, em Santo André, numa área de população de origem rural e semi-rural. Entre as funções desempenhadas pela escola que aponta, destaquemos as de: "a) agência urbanizadora, acelerando o processo de desculturação do rústico ainda sobrevivente na área e a sua substituição pelo urbano; b) agência integradora da população na comunidade nacional brasileira, que se vem constituindo pela participação sempre crescente de contingentes rurais e semirurais numa cultura urbana; (...) d) canal de mobilidade social vertical para as famílias da área, por equipar seus filhos com recursos mínimos para o seu acesso às profissões manuais 'qualificadas' (...)”. PEREIRA, 1960 (a), págs. 125-126. 
Quadro XXVIII

Porcentagens trienais de repetência e de conclusões de curso, relativas aos totais de matrículas efetivas, nas escolas primárias brasileiras (*), 1940-1957

\begin{tabular}{|c|c|c|c|c|}
\hline \multirow{2}{*}{ TRIEANIOS } & \multicolumn{2}{|c|}{$\begin{array}{l}\text { PORCENTAGLM DE } \\
\text { REPETENCIAS }\end{array}$} & \multicolumn{2}{|c|}{$\begin{array}{l}\text { PORCENTAGEM DE } \\
\text { CONCLUSÕES DE CURSO }\end{array}$} \\
\hline & $\begin{array}{l}\text { Escolas } \\
\text { urbanas }\end{array}$ & $\begin{array}{l}\text { Escolas } \\
\text { rurais }\end{array}$ & $\begin{array}{l}\text { Escolas } \\
\text { urbanas }\end{array}$ & $\begin{array}{l}\text { Escolas } \\
\text { rurais }\end{array}$ \\
\hline $\begin{array}{l}1940 / 42 \ldots \ldots \ldots \ldots \\
1943 / 45 \ldots \ldots \ldots \ldots \\
1946 / 48 \ldots \ldots \ldots \ldots \\
1949 / 51 \ldots \ldots \ldots \ldots \\
1952 / 54 \ldots \ldots \ldots \ldots \\
1955 / 57 \ldots \ldots \ldots \ldots\end{array}$ & $\begin{array}{l}37,5 \\
36,8 \\
36,2 \\
36,1 \\
34,9 \\
33,1\end{array}$ & $\begin{array}{l}54,1 \\
53,4 \\
54,1 \\
53,6 \\
50,1 \\
48,6\end{array}$ & $\begin{array}{l}10,1 \\
10,5 \\
10,3 \\
10,8 \\
11,3 \\
11,2\end{array}$ & $\begin{array}{l}6,3 \\
6,4 \\
5,5 \\
4,5 \\
4,5 \\
4,9\end{array}$ \\
\hline
\end{tabular}

(*) Omitimos os dados referentes às escolas distritais, cujos valores se situam sempre entre os das urbanas e rurais.

Fonte: Ministério da Educação e Cultura (apud PEREIRA, 1960 (a), págs. 70-71).

\section{Quadro XXIX}

Porcentagens de alfabetizados na população, de 10 anos ou mais, em 1950, e de crianças de 7 a 11 anos que freqüentam escola e de regentes de classe com formação apenas primária (*), em 1964, por Estado

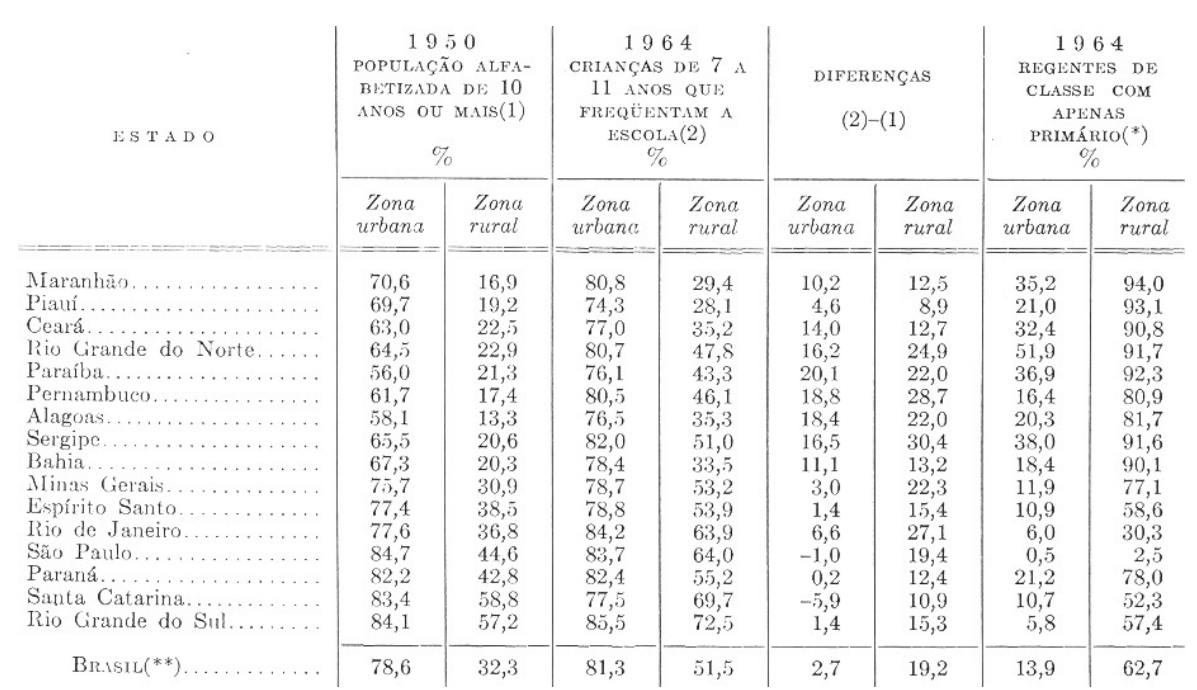

(**) Inclusive os Estados das regiões Norte e Centro-Oeste.

Fontes: Pesquisas sobre as populações urbanas e rurais do Brasil, 1954, p.88, e Censo Escolar de 1964.

Pelo quadro XXVIII vê-se como no período considerado permanecem, quase sem alteração, as porcentagens de repetência, bem mais altas nas áreas rurais do que nas urbanas. Porcentagens desfavoráveis às áreas rurais ocorrem também nas proporções de conclusão de curso. (A respeito dessa, aquela desvantagem ainda se realça mais quando nos lembramos que ao contrário das urbanas, onde a porcentagem ideal de conclusão de curso se situaria, devido à duração do curso, de quatro a cinco anos, entre 20 a 25 por cento, para as rurais, onde a duração é no geral de três anos, a porcentagem ideal de conclusão de curso se situaria ao redor de 30.) Com o correr dos anos, nota-se ligeira melhora em ambos os problemas, com exceção das conclusões de curso nas escolas rurais, que apresentam diminuição.

O quadro XXIX - onde figuram, separadamente para as zonas urbanas e rurais, as porcentagens de alfabetizados em 1950, as das crianças de 7 a 11 anos que frequientavam escola em $1964^{165}$, e as de regentes de classe também em 1964 com formação apenas primária, - esclarece aspectos da atuação da escola primária, no tempo, como influência urbanizadora. Sobressai, tanto nos dados referentes à alfabetização em 1950, como nos de criança em escola em 1964, praticamente hoje, a desigual penetração da escola nas várias regiões, e nas áreas urbanas comparadas com as zonas rurais do Brasil. Os menores e maiores índices encontram-se, respectivamente, nos Estados menos e mais adiantados (estes últimos, grosso modo, são os que figuram no quadro de Minas Gerais para baixo).

Comparando-se as quotas de alfabetização em 1950 com as taxas de freqüência de crianças à escola em 1964 (como prenunciadora da

${ }^{165}$ Há, entre os resultados do Censo Escolar de 1964, dados relativos à frequiência à escola para dois grupos de idade, de 7 a 11 anos e de 12 a 14 anos. As variações nas porcentagens, para um e outro, de Estado a Estado, são no geral semelhantes. Para os propósitos da análise efetuada no texto, bastou utilizar os dados para o grupo de 7 a 11 anos, que nos pareceu mais significativo.

(*) Completo ou incompleto. 
alfabetização da população em data futura), tem-se a impressão de que as diferenças de Estado para Estado diminuem, principalmente para as populações urbanas. Percebe-se este fato examinando-se as colunas de diferenças entre aquelas duas séries de porcentagens, diferenças que devem ser tomadas como índices grosseiros do ritmo de penetração da educação primária durante as últimas décadas. Tanto nas zonas rurais como nas urbanas são os Estados com menores quotas de alfabetizados em 1950 que apresentam progresso mais sensível. Nas zonas urbanas ocorre clara homogeneização de taxas, enquanto nas zonas rurais existe, com várias exceções, apenas tendência para isso. Resulta daí que os dados de freqüência à escola em 1964 apresentam diferenças muito maiores entre as zonas rurais dos vários Estados do que entre as suas zonas urbanas. $\mathrm{O}$ mesmo se nota para as proporções de regentes de classe com formação apenas primária. (Estas porcentagens são relevantes para sublinhar variações quanto à qualidade de ensino. Para nós, contudo, o interesse delas jaz em indicar algo como o grau de desvio desse ensino, relativamente à tradição. Pressupomos educação além da primária significar maior integração à sociedade nacional e ao estilo urbano de vida ${ }^{166}$. Noutras palavras, a proporção de regentes de classe com formação apenas primária, muitas vezes incompleta, é um índice da eficiência ou ineficiência com que atua a atividade ensino-aprendizagem como fator urbanizador). Voltando ao ponto que acima se tratava: tanto esse índice da eficácia do educador como agente de urbanização, como as proporções de crianças em escolas primárias, revelam notável grau de homogeneização, processo em curso nas últimas décadas, do nosso mundo urbano. Mundo urbano este, lembremo-

\footnotetext{
166 Talvez neste ponto seja relevante considerar a pesquisa de Aparecida GOUVEIA, sobre o prestígio atribuído a ocupações por professores secundários nas capitais e em cidades do interior de vários tamanhos, no Rio Grande do Sul, São Paulo e Pará, na qual o principal resultado foi, apesar de haver pequenas diferenças no sentido esperado, "a grande semelhança que existe. não apenas entre a capital e o interior, pois esta poderia explicar-se pelo fato de o recrutamento dos professores principalmente em São Paulo, ser de âmbito estadual e não local, mas, acima de tudo, a semelhança entre Estados que apresentam índices demográfico-econômicos tão diferentes como São Paulo e Pará”. GOUVEIA, 1965, p.78. Tais avaliações de prestígio ocupacional comuns a professores secundários em diversas partes do país, decorreria de serem eles portadores de uma cultura comum, característica das classes médias do Brasil urbano.
}

nos, que abrange desde grandes metrópoles até núcleos bem modestos. A tendência nas zonas rurais é consideravelmente mais fraca ${ }^{167}$.

Sob outra perspectiva, tais fatos significam que, ao passo que na área urbanizada do país (coincidente, grosso modo, com os Estados mais adiantados) amenizam-se as diferenças entre campo e cidade quanto à educação primária, nas outras (nos Estados atrasados), acentuam-se os desníveis entre as zonas urbanas e as rurais.

Aos efeitos urbanizadores da educação primária juntam-se os dos meios de comunicação de massa. O conhecimento desse campo, fora informações esparsas, em geral pouco sistemáticas, dos estudos de comunidade, é quase nulo. Podemos apenas situar o problema, com dados estatísticos globais. Coletamos pois informações relativas ao rádio, à imprensa e ao cinema, por Estados, agrupados quanto ao grau de urbanização e, quando possível, separadamente para capitais e zonas do interior, Façamos sobre elas alguns breves comentários.

No quadro XXX figuram dados sobre as estações de rádio no país, na sua grande maioria em ondas médias ${ }^{168}$, para os Estados do Centro-sul, do Sul, e demais Estados, no período de 1937 a 1957. No início eram poucas e altamente concentradas na parte mais urbanizada do Brasil: mais de 80 por cento das sessenta e três estações de 1937 estavam no Centro-sul. Com o tempo, crescem em número (de 63 nesses vinte anos passam a 637) e difundem-se para os outros Estados: nas áreas menos urbanizadas (os "demais Estados" do quadro), aumentam de seis para cento e onze nesse período, de cerca de 10 para mais de 17 por cento do total de estações do

\footnotetext{
${ }^{167}$ É claro que tais fatos resultam de já terem sido alcançados, em 1950, nos Estados mais adiantados, níveis altos de alfabetização da população urbana, enquanto havia ainda ampla margem para melhoria entre as suas populações rurais. Isto não invalida, porém, as conclusões a que se chega sobre a homogeneização, quanto à educação primária, dos centros urbanos no Brasil. Outra observação, no entanto, precisa ser feita. Os dados existentes não nos permitem verificar até que ponto persistem diferenças quanto à alfabetização e à freqüência a escolas entre cidades conforme se

localizem em áreas urbanizadas ou não-urbanizadas do país (ver capítulo IV).
${ }^{168}$ Em 1960, 604 das 735 estações existentes no Brasil eram de ondas médias; 215 situavam-se nas capitais e 520 no interior (Anuário Estatístico do Brasil, 1962).
} 
país. Nota-se também a difusão de estações de rádio pelas cidades do interior do Centro-sul, adensando-se grandemente aí as comunicações por esse veículo: de ao redor de Vinte e cinco no interior do Centro-sul em 1937, multiplicam-se até atingirem bem mais de trezentas (cerca de 85 por cento do total para esses Estados), em 1957.

\section{Quadro XXX}

Números e porcentagens de estações de rádio (*), por grupos de Estados, em 1937,

$$
1950 \text { e } 1957
$$

\begin{tabular}{|c|c|c|c|c|c|c|}
\hline \multirow{2}{*}{ Grupos de Estados } & \multicolumn{2}{|c|}{1937} & \multicolumn{2}{|c|}{1950} & \multicolumn{2}{|c|}{$1957(* *)$} \\
\hline & $N$ & $\%$ & $N$ & $\%$ & $N$ & $\%$ \\
\hline & \multicolumn{6}{|c|}{ Centro-sul } \\
\hline $\begin{array}{c}\mathrm{PR}-\mathrm{SP}-\mathrm{RJ}-\mathrm{MG}- \\
\mathrm{DF}\end{array}$ & 52 & 82,6 & 198 & 66,0 & 40,2 & 63,1 \\
\hline \multicolumn{7}{|c|}{ Sul } \\
\hline $\mathrm{RS}-\mathrm{SC}$ & 5 & 7,9 & 63 & 21,0 & 124 & 19,5 \\
\hline $\begin{array}{l}\text { Interior dos demais } \\
\text { Estados }\end{array}$ & 6 & 9,5 & 39 & 13,0 & 111 & 17,4 \\
\hline Brasil & 63 & 100,0 & 300 & 100,0 & 637 & 100,0 \\
\hline
\end{tabular}

(*) Em 1957, estações de rádio e televisão.

(**) Em 1957, apenas 16 e 19 por cento, respectivamente, das estações do Centro-sul e do Sul, encontravam-se nas capitais dos Estados; nos demais Estados isso não acontecia Com apenas 19 por cento das estações. Não havia, para 1937 e 1950, sobre esse ponto, as informações necessárias (no total do país, apenas 25 das 63 estações em 1937 eram no interior).

Fonte: Anuários Estatísticos da Brasil, 1938, 1952 e 1959.

Este índice, utilizado para medir-se o alcance do rádio entre as diversas populações brasileiras, é altamente insatisfatório. Ele não nos revela nada acerca da distribuição de receptores, do cunho urbano dos programas transmitidos e ouvidos ${ }^{169}$, se de estações de pequenas cidades do

${ }^{169}$ Escreve Borges COSTA, sobre os habitantes de uma área rural do Alto São Francisco, em Minas Gerais, a que denomina Retiro: "Os retirenses que ouvem rádio fazem-no no máximo durante uma hora por dia, depois do trabalho; a maior parte destes são homens e seus programas preferidos são os 'programas caipiras', pois gostam de ouvir falar em fatos e coisas 'da roça' e de ouvir as músicas 'caipiras', que se assemelham muito àquelas que eles próprios cantam, ao acompanhamento da viola interior ou de grandes metrópoles, etc. Mesmo assim, é fácil perceber-se quão fraca é ainda a teia de comunicações por rádio em grande parte do território brasileiro, quão pouco atingidas são as suas populações, e, por conseguinte, até que ponto permanecem imersas em seu localismo (o rádio no final de contas é o veículo de mais amplo acesso): no conjunto dos quinze Estados que constituem a região menos urbanizada, existiam, em 1957, cento e onze estações, das quais apenas pouco mais de uma vintena não se localizava nas capitais.

Vejamos agora a penetração da imprensa nas várias partes do país. O quadro XXXI registra o número de jornais, por grupos de Estados, em 1937 e 1960. Crescem no período, conjuntamente os diários e os jornais de periodicidade menos freqüente, de 882 a 1.166, e apresentam-se um pouco mais concentrados nas regiões mais urbanizadas, no fim mais do que no início do período: em 1960, cerca de dois terços de todos os jornais e 12 por cento, respectivamente, estavam nos Estados do Centro-sul e nos do Sul. Acresce ainda o fato de haver, proporcionalmente, menos gazetas, jornais semanais ou quinzenais típicos das cidades do interior, nas áreas menos urbanizadas, que nas mais urbanizadas. Tanto numa data como na outra, nos Estados dessas últimas áreas, há cerca de quatro gazetas para cada diário, enquanto nos demais Estados essa relação é ao redor de 2,5. Isto indica a maior difusão de jornais pelo interior das áreas urbanizadas.

Quadro XXXI

Número de jornais diários e de gazetas (*), por grupo de Estados, em 1937 e 1960

\begin{tabular}{ccccc} 
& \multicolumn{2}{c}{ Diários } & \multicolumn{2}{c}{ Gazetas (*) } \\
Grupos de Estados & 1937 & 1960 & 1937 & 1960 \\
& \multicolumn{2}{c}{ Centro-sul } & & \\
PR - SP - RJ - MG - DF & 97 & 144 & 447 & 622 \\
& Sul & & & \\
RS - SC & 25 & 26 & 97 & 111
\end{tabular}

ou do violão, nas festas e serões. Há cerca de dez rádios em Retiro [para uma população de aproximadamente 400 pessoas]; a maior parte deles funciona com força de baterias". Borges COSTA, 1960, p. 125. 


$\begin{array}{ccccc}\text { Interior dos demais Estados } & 60 & 77 & 154 & 186 \\ \text { Brasil } & 184 & 247 & 698 & 919\end{array}$

(*) Em 1937, tomamos a categoria dos periódicos semanais; em 1960, as gazetas estão definidas como periódicos do tipo jornal, cuja periodicidade é inferior a quatro vezes por Semana.

Fonte: Anuários Brasileiros de Estatísticas, 1938 e 1962.

No quadro XXXII, temos para um período recente, de 1955 a 1960, dados sobre a tiragem média de jornais, separadamente para as capitais e as diversas zonas do interior. O intervalo no tempo é curto para observar-se tendências ${ }^{170}$. Importa mais notar as grandes diferenças, em 1960 ainda, da relação de exemplares por cem habitantes nas várias áreas. Há enormes desníveis entre as capitais e as zonas do interior. Isto ocorre mesmo nas áreas mais urbanizadas, no Centro-sul e no Sul, onde a taxa para o Rio e São Paulo é de catorze a dezoito vezes a das zonas do interior; no caso das outras capitais essa razão é de seis a sete vezes (relativa à taxa da zona do interior da área urbanizada), Entre as zonas do interior da parte urbanizada e as do restante do país ocorre desnível de grandeza semelhante: desce-se de quatro a cinco exemplares por cem habitantes para bem menos de um.

${ }^{170}$ Há em geral aumento em todos os casos de 30 a 100 por cento na tiragem média, no período; a principal exceção, o enorme crescimento na tiragem dos jornais não-diários no Rio e em São Paulo, discrepa de tal maneira do quadro geral, que nos faz pensar em erro ou cobertura desigual da estatística nas duas datas.
Quadro XXXII

Tiragem média de jornais diários e gazetas (*), para capitais e zonas do interior, 1955 e 1960, e número de exemplares (diários e gazetas) por 100 habitantes em 1960

\begin{tabular}{|c|c|c|c|c|c|}
\hline \multirow{2}{*}{ CAPITAIS E ZONAS DO INTERIOR } & \multicolumn{2}{|c|}{1955} & \multicolumn{2}{|c|}{1960} & \multirow{2}{*}{$\begin{array}{c}\text { Número de } \\
\text { exemplares } \\
\text { (diarios e } \\
\text { gazetas) por 100 } \\
\text { habitantes, } \\
1960\end{array}$} \\
\hline & Diários & Gazelas $\left({ }^{*}\right)$ & Diários & Gazetas $(*)$ & \\
\hline \multicolumn{6}{|l|}{ Capitais } \\
\hline $\begin{array}{l}\mathrm{SP}-\text { Rio de Janeiro } \ldots \ldots \ldots \ldots \ldots \\
\text { Outras } \ldots \ldots \ldots \ldots \ldots \ldots \ldots \ldots\end{array}$ & $\begin{array}{r}1.896 .088 \\
765.600\end{array}$ & $\begin{array}{l}202.000 \\
243.250\end{array}$ & $\begin{array}{l}2.500 .654 \\
1.071 .600\end{array}$ & $\begin{array}{r}2.608 .000 \\
330.960\end{array}$ & $\begin{array}{l}72 \\
29\end{array}$ \\
\hline \multicolumn{6}{|l|}{ Interior } \\
\hline Paraná - SP - RJ - MG...... & 234.360 & 447.300 & 314.780 & 893.180 & 5 \\
\hline RGS - S. Catarina . . . . . . . . . & 64.900 & 169.625 & 58.100 & 221.940 & 4 \\
\hline Interior dos demais Fstados........ & 14.100 & 113.524 & 28.250 & 159.722 & 0,7 \\
\hline BRASIL . . . . . . . . . & 2.975 .048 & 1.175 .699 & 3.973 .384 & 4.213 .802 & 12 \\
\hline
\end{tabular}

(*) Periódico do tipo jornal, cuja periodicidade é inferior a quatro vezes por semana. Fonte: Anuários Brasileiros de Estatística, 1951 e 1965.

Essas diferenças devem-se, em boa medida, ao fato de ser o analfabetismo bem mais prevalecente em certas regiões e zonas do Brasil que em outras. Assim o degrau relativamente menor existente entre as duas grandes metrópoles brasileiras e as demais capitais, do que o existente entre essas e as zonas do interior, decorre da homogeneização, já notada, na educação primária no Brasil urbano. $\mathrm{O}$ analfabetismo, porém, não explica toda a diferença, Dados preliminares do censo de 1960, para as três principais regiões do Brasil, possibilitam-nos verificar essa assertiva ${ }^{171}$. No quadro XXXIII figuram os exemplares de jornais por cem pessoas da população de 15 anos ou mais e das que entre elas são alfabetizadas, para o Sul, Leste e o Nordeste. Embora diminuam as diferenças, elas permanecem: o desnível das taxas cai de seis a sete vezes para cerca de quatro.

171 VII Recenseamento geral do Brasil, 1960, Censo demográfico, resultados preliminares, série especial, vol. II, IBGE, Rio de Janeiro, 1965. São resultados obtidos por processo de amostragem probabilística, a partir de amostra de cerca de 1,27 por cento da população. 
Quadro XXXIII

Número de exemplares (diários e gazetas) por 100 habitantes de 15 anos ou mais e por 100 alfabetizados na mesma população, para três regiões, 1960

$\begin{array}{ccc}\text { Região }(*) & \text { População de } 15 \text { anos ou mais } & \text { Alfabetizados de } 15 \text { anos ou mais } \\ \text { Sul } & 29 & 40 \\ \text { Leste } & 24 & 39 \\ \text { Nordeste } & 4 & 10\end{array}$

(*) Divisão regional adotada pelo Censo: Nordeste, do Maranhão a Alagoas; Leste, de Sergipe ao Rio de Janeiro e Guanabara; e Sul, de São Paulo para o Sul.

Fonte: Censo de 1960 (amostra) e Anuário Brasileiro de Estatística, 1962.

Examinemos finalmente os dados do quadro XXXIV sobre a frequiência a cinemas, também segundo as capitais e diferentes zonas do interior, para 1957 e 1961. Mesmo em intervalo tão curto, assinalam-se aumentos, nas várias áreas, do número de espectadores, proporcionalmente maior nas menos urbanizadas do interior, com exceção das duas maiores metrópoles do Brasil, Rio e São Paulo (aí a queda deve-se possivelmente à concorrência feita ao cinema pela televisão).

\section{Quadro XXXIV}

Número de espectadores de cinemas e freqüência média anual, por capitais e zonas do interior, em 1957 e 1961

Capitais e zonas do interior 1957 (milhões) 1961 (milhões) Freqüência média anual em 1961 (*)

\begin{tabular}{cccr} 
& \multicolumn{3}{c}{ Capitais } \\
SP-RJ & 117,1 & 89,2 & 12,5 \\
Outras $(* *)$ & 75,0 & 79,5 & 16,5 \\
PR - SP-RJ-MG & 107,1 & Interior & \\
RS - SC & 20,9 & 20,5 & 4,4 \\
Interior dos demais Estados & 22,1 & 24,9 & 3,6 \\
Brasil & 344,3 & 328,5 & 0,9 \\
& & 4,0
\end{tabular}

(*) Número de espectadores em 1961 dividido pela população em 1960.

(**) Inclusive Brasília.

Fonte: Anuários Brasileiros de Estatística, 1959 e 1963.

O nosso interesse maior, contudo, jaz nas variações de incidência do cinema pelas várias partes do país, isto é, das taxas de freqüência média anual. De novo encontramos dois degraus, um entre as capitais e as zonas urbanizadas do interior e o outro entre essas e as demais, cada degrau equivalendo a uma divisão da taxa por um fator da ordem de quatro ou cinco.
Em suma, esses índices, embora grosseiros, nos permitem ver como a população brasileira, quanto à "exposição" aos veículos de comunicação de massa, o rádio, a imprensa e o cinema, apresenta desníveis pronunciados entre as capitais e as zonas do interior, e entre essas, as da área urbanizada do Centro-sul e do Sul e as do restante do país.

A influência do rádio é, bem possivelmente, a que mais se faz sentir entre as populações interioranas. Entre os nossos índices, o número de estações de rádio foi o único a exibir sensível desconcentração territorial. Ele é pouco limitado pela difusão desigual da educação, embora mesmo neste caso esta deva também ter o seu efeito, pela transformação de idéias, valores e de mundo mental que acarreta.

Verificamos igualmente que se constitui uma teia mais densa de comunicações na área mais urbanizada do Brasil, envolvendo tanto capitais como zonas do interior, teia na qual hoje se junta a ação da televisão ${ }^{172}$.

Não tocamos, todavia, no que é possivelmente o maior desnível, o existente entre as populações rurais e as dos centros urbanos, mesmo pequenos, mormente nas áreas que denominamos não-urbanizadas. De fato,

${ }^{172}$ Levantamento na base de amostras da população, realizado em 1961-62 em São Paulo e, em 1962-63, em cidades de vários tamanhos do interior paulista, pelo Instituto Brasileiro de Economia, mostrava considerável difusão da televisão. Entre as famílias investigadas, as seguintes porcentagens tinham televisão: 45,1 por cento na cidade de São Paulo; 41,6 por cento em Santos, Campinas e Sorocaba (escolhidas entre as cidades com mais de setenta mil habitantes); 19,4 por cento em Rio Claro, Araraquara e Marilia (entre as de trinta e setenta mil habitantes); e 9,4 por cento em Jacareí, Bragança Paulista, Bebedouro, Batatais, Itapetininga e Birigüi (entre as de cinco a trinta mil habitantes). As porcentagens entre as famílias operárias desses grupos de cidades do interior eram, respectivamente, 28,9, 12,1 e 5,5 por cento. Pesquisas sobre orçamentos familiares. Cidade de São Paulo e interior do Estado, s/d. Apenas como termo de comparação, vejamos algumas estatísticas médias, globais, para os EUA (cuja população total é de 200 milhões), sociedade de massa, onde a integração do sistema industrial atingiu grau dos mais avançados: perto de 60 milhões de americanos vão semanalmente ao cinema; mais de 43 milhões têm em casa pelo menos um aparelho de televisão funcionando em média cinco horas e um quarto por dia; a tiragem diária de jornais é de cerca de 57 milhões de exemplares; há no país mais de 600 revistas especializadas para agricultores, com tiragem total de 245 milhões de exemplares; 6 milhões de discos são comprados semanalmente; e outros 100 milhões são tocados por semana nas 700 mil caixas de música (juke-boxes) existentes no país. BENSMAN e ROSENBERG, 1963, p.170. 
todas as taxas utilizadas, com base em dados para Estados ou no máximo separadamente para a capital e o seu interior, não puderam captar a barreira existente às comunicações nos limites urbanos, particularmente para as camadas rurais inferiores ${ }^{173}$.

Entrevemo-la, pelos estudos de comunidade, no geral em observações neles contidas, esparsas e pouco sistemáticas ${ }^{174}$. Dois estudos ao menos, mediante cuidadosa coleta de dados entre amostras da população, avaliaram com certa precisão o fenômeno. Em estudo de município no oeste do Paraná (Toledo; sede com cerca de 2.000 pessoas), Oberg organizou um índice de acessibilidade aos veículos de comunicação, na base de alfabetização, hábito de leitura e de ouvir rádio, de frequiência a cinema e a igreja. Por esse índice, enquanto 22 por cento dos citadinos eram colocados no nível mais baixo da escala, aí ficavam 73 por cento dos da zona rural. Assinale-se que nesse município, segundo o autor, o "analfabetismo (...) é raro e, portanto, não é obstáculo ao influxo de informações" e que embora para toda a comunidade "a acessibilidade aos meios de comunicação seja baixa (...) [é] muito melhor do que a que prevalece em amplas áreas do Brasil rural, onde o analfabetismo é alto, o número de rádios pequeno e os jornais raramente encontrados" 175 .

Outro estudo, realizado por Blair ${ }^{176}$, em pequena comunidade agroindustrial (usina de arroz; população de dois a cinco mil pessoas), na parte leste do Rio Grande do Sul, uma das áreas urbanizadas do Brasil portanto, esclarece mais completamente a questão. Torna claro não decorrer a

\footnotetext{
${ }^{173}$ Os maiores proprietários de terra, nas áreas de agricultura avançada, realmente vinculam-se, pela estrutura social, tanto no mundo rústico como ao urbano. Veja-se, por exemplo, H. HUTCHINSON, 1957, págs. 101-102.

${ }^{174}$ Quanto a isso, veja-se, por exemplo, o contraste entre a cidade de Cerrado (nome fictício; 2.420 habitantes) e fazendas próximas (com 400 pessoas) de comunidade do Alto São Francisco em Minas Gerais, analisadas por Borges COSTA (1960, págs. 123-131) e entre a cidade de Xique-Xique (3.800 habitantes) e a vila vizinha de Marrecas (2.000 habitantes), por Altenfelder SILVA (1961, págs. 16,5$180)$.

${ }^{175}$ OBERG, 1957, págs. 81-83.

${ }^{176}$ BLAIR. 1960
}

exposição a informações pelos meios de comunicação, da existência apenas de tais meios, mas que

(...) padrões de exposição a informações variam tão amplamente quanto padrões de comportamento social associados a diversas posições de status. Aqueles padrões desenvolvem-se como parte das atividades sociais, envolvendo interação com outras pessoas de maneira institucionalizada, dentro de dinâmicas situações de vida ${ }^{177}$.

Noutras palavras, a teia de comunicações é parte integrante da estrutura social global. Nesta residem as "barreiras" aos meios de comunicações porventura existentes. Coletando dados relativos a exposição aos meios de comunicação, visitas sociais e contato com pessoas de fora para três grupos ocupacionais, trabalhadores agrícolas, operários de usina e empregados de escritório, Blair conclui estar cada qual associado a padrão definido de exposição a comunicações. Relatemos suas conclusões ${ }^{178}$, mantendo mesmo a secura das expressões de que se utiliza para caracterizar tais padrões:

1. Trabalhadores agrícolas (analfabetos): predominância de informações interpessoais; infreqüente exposição a novas informações, conteúdo local e provinciano das mesmas; orientação para valores e padrões tradicionais de folk;

2. Operários urbanos (semi-alfabetizados): predominância de informações orais e exposição direta aos meios de comunicação; aquelas reforçando esses; maior freqüência de novas informações; conteúdo freqüentem ente de ocorrências não-locais; transição entre os valores da sociedade de folk e a moderna;

3. Empregados de escritório tipicamente urbanos (alfabetizados): preponderância de exposição direta aos meios de comunicação de massa; ocorrência diária de novas informações; conteúdo das informações: urbano e cosmopolita; orientação para os valores modernos comuns em grandes cidades brasileiras.

\footnotetext{
${ }^{177}$ Ibidem, p.72

${ }^{178}$ Ibidem, p.69.
} 
Isso, em comunidade pequena, situada todavia em zona urbanizada do país. Vê-se perfeitamente, por esses dados, como a linha divisória entre localismo e integração à sociedade nacional passa pelo meio da comunidade local. Pelo menos nas comunidades das regiões urbanizadas do Brasil, onde a integração ao mercado e à sociedade urbano-industrial atinge certo grau. Nessas regiões, classes médias e altas de centros urbanos dos mais variados tipos e tamanhos participam crescentemente de uma mesma cultura urbana nacional.

Apesar de as pesquisas sociais existentes não permitirem caracterizar bem o curso de tal processo de integração de toda a ordem de localidades, quanto a padrões de conduta e valores, os resultados de nossa análise do desenvolvimento sócio-econômico, das transformações políticas e das tendências gerais de burocratização, secularização e industrialização, forçanos a pressupor que metrópoles e comunidades maiores e menores, espalhadas pelo país, integrem-se na sociedade urbano-industrial pelas camadas superiores e médias urbanas. Nos locais onde a mudança econômica e social intensifica-se, até as camadas inferiores dos centros urbanos, em boa proporção de origem rural, já constituem campo para a transição do tradicional para o moderno.

Pesquisa realizada por Joseph Kahl ${ }^{179}$ em cidades pequenas situadas nas áreas urbanizadas de Minas Gerais e Rio Grande do Sul ${ }^{180}$, diretamente preocupada com valores sociais, corrobora e acrescenta novos aspectos a esse quadro.

Com base em questionário aplicado a amostras, estudou Kahl, mediante refinada e inteligente análise estatística, a relação, de um lado, de status sócio-econômico e grau de urbanização (habitantes das pequenas cidades ou da metrópole; subdividindo esses últimos conforme foram criados ou não até a idade de dez anos em pequenas cidades; os três grupos resultantes são denominados, para facilidade de expressão, de provincianos,

\footnotetext{
${ }^{179}$ KAHL, 1965.

180 A cidade de Dores de Campo e a vila Barroso, no mesmo município, em Minas Gerais, e Jaguarão no Rio Grande do Sul (informações pessoais do autor).
}

migrantes e metropolitanos) e, do outro, com valores modernos ${ }^{181}$. As várias escalas, combinadas em um índice de modernismo, devem ser mencionadas: baixo fatalismo, baixa integração a parentes, preferência por vida urbana, individualismo, baixa percepção de estratificação comunitária, participação nos meios modernos de comunicação e baixa percepção da estratificação de oportunidades de vida.

A principal conclusão para os nossos objetivos acha-se contida no quadro XXXV, onde se relaciona o nível de modernismo com status sócioeconômico e o grau de urbanização da população.

\section{Quadro XXXV}

Notas médias de tradicionalismo-modernismo (*) no Brasil, por status sócioeconômico e grau de urbanização

Status sócio-econômico Número de casos Grau de urbanização

\begin{tabular}{cccccc} 
& \multicolumn{5}{c}{ Metropolitanos } \\
Alto & 207 & 4,6 & 4,3 & 4,4 & 4,5 \\
Médio & 205 & 3,8 & 3,3 & 3,2 & 3,5 \\
Baixo & 215 & 2,8 & 2,5 & 2,3 & 2,5 \\
Total & 627 & 4,0 & 2,9 & 3,1 & 3,5
\end{tabular}

(*) Variação de um a seis; quanto mais altas as notas, mais modernismo de valores. Fonte: KAHL, 1965, cap. III, p.6.

Dois fatos básicos sobressaem do quadro: primeiro, os valores modernos intensificam-se à medida que se vai dos status mais baixos para os mais altos e das cidades menores para a metrópole e, em segundo lugar, a influência do status sobre o modernismo é bem mais forte que a do grau

${ }^{181}$ A escala de status sócio-econômico adotada baseia-se em dados sobre a educação, ocupação e percepção subjetiva de classe. A amostra incluía 311 metropolitanos (residentes no Rio de Janeiro e criados em cidades grandes), 132 migrantes (criados em cidades pequenas e residentes no Rio no momento da pesquisa) e 184 provincianos (residentes nas cidades pequenas quando da pesquisa). Como não se tencionava medir os valores da população brasileira, mas sim estudar inter-relações dos valores com outras variáveis, a fim de esclarecer processos sociais, excluíram-se nas amostras os dois extremos na hierarquia social. Elas abrangeram, em suma, homens de 25 a 50 anos de idade, situados em ampla faixa mediana da estrutura social ("we deliberately excluded (...) those with university degrees, and marginal workers who did not have steady jobs (....) [and included] men who were steady wage and salary workers"; Ibidem, cap. I, p.16). O uso que fizermos dos resultados da pesquisa deve levar tais fatos em conta. 
de urbanização da população ${ }^{182}$. Citemos o autor, antes de fazermos os nossos comentários. Escreve Kahl:

Os dados sugerem serem os homens de status alto das cidades de província plenos participantes da vida moderna. Não sabemos ao certo se aprenderam os valores modernos na escola ou de outros modos; mas as entrevistas qualitativas indicam que educação, viagens constantes à metrópole, relações pessoais com amigos e parentes de status alto noutras partes do país, e o uso dos meios de comunicação, tudo converge para influenciar seu modo de ver as coisas. (Deve-se lembrar, é claro, que não estamos tratando de fazendeiros, mas de homens de negócio e empregados de escritório em pequenas cidades.)

Em contraste, homens de status inferior são algo mais influenciados pelo seu ambiente imediato. Talvez viajem menos; nossos dado claramente indicam menor participação dos meios de comunicação. Esses fatores podem muito bem ser reforçados por diferenças qualitativas no conteúdo da educação primária das pequenas cidades. De qualquer modo, os provincianos de status médio ou baixo são um pouco mais tradicionais do que aqueles em posição correspondentes nas metrópoles (cap. III, págs. 4-5)

Alguns dos fatores colocados por J. Kahl como possíveis determinantes dessa situação - exposição a veículos de comunicação de massa e a educação (inclusive sua qualidade), - já foram postos em destaque na nossa análise anterior.

Contudo há outros pontos a serem notados, para melhor entender o fato de valores modernos na população estudada dependerem mais do status sócio-econômico do que do grau de urbanização. Tratam-se de comunidades localizadas nas áreas urbanizadas do Centro-sul e do Sul do país e, ainda mais, de comunidades em mudança social relativamente

${ }^{182}$ Para as variações de normas sociais de fertilidade (o número de filhos considerado ideal para a família), residência na metrópole ou em cidades interioranas, é mais importante do que status sócioeconômico. Ibidem, cap. IX, p.37. Ver também acima, neste trabalho, na p.152, a nota 102. rápida $^{183}$. Por outro lado, como a amostra deliberadamente deixou de lado os extremos da hierarquia social ${ }^{184}$, excluíram-se as pessoas das cidades provincianas mais presas a valores tradicionais, as situadas na parte inferior da estrutura, e que possivelmente apresentariam maiores contrastes com as populações correspondentes das metrópoles (deixando-se de mencionar as camadas inferiores da população rural).

Em suma, essa pesquisa juntamente com as de Blair e de Oberg, examinadas acima, assim como os dados apresentados quanto à educação ${ }^{185}$ e aos meios de comunicação de massa, tendem, todos, a nos dar a idéia de relativa homogeneização dos centros urbanos, menores e maiores, na parte urbanizada do país, pelo menos nas porções médias e superiores da estrutura social. O tradicionalismo local tenderia nessa área, cada vez mais, a restringir-se ao mundo rústico e, nos centros urbanos, à camada inferior de sua população.

Mesmo na área não-urbanizada haveria clara diferenciação ruralurbana. Harris, por exemplo, no seu estudo de Rio das Contas, na Bahia, pequena comunidade situada em área isolada e não-urbanizada, salienta ser

${ }^{183}$ A análise de KAHL, por exemplo, referente à mobilidade social, de uma geração para outra, chega à conclusão que a taxa de mobilidade nas cidades de província não é menor do que a da capital. À guisa de explicação, assinala: "we chose towns which have recently gone through their first spurt of industrialization and commercialization, thus probably have temporarily high rates of mobility". Ibidem, cap. IV, p.5.

${ }^{184}$ Ver nota 79, supra.

${ }^{185} \mathrm{Na}$ pesquisa de KAHL (Ibidem, cap. IV, págs. 17a-18a) verificou-se relação substancial, dentro de cada camada (definida pelo status ocupacional do pai), entre o tamanho da comunidade em que a pessoa se criou até os 10 anos e o nível da educação que adquire. (Os dados neste caso são apresentados para todos os informantes juntos, provincianos, imigrantes e metropolitanos.) Isso confirma as nossas conclusões anteriores sobre a educação, para amostras de determinadas comunidades, com controle rigoroso do nível sócio-econômico. Note-se também que, por esses resultados, a influência do tamanho da comunidade sobre a educação deixa de se fazer sentir nos níveis mais altos da hierarquia. Entre as pessoas cujos pais tinham ocupação não-manual superior (profissionais e semiprofissionais; empregadores ou gerentes com cinco subordinados ou mais), a educacão média situava-se ao redor do secundário incompleto ou completo, independentemente, ao contrário do que acontecia com os outros níveis, do tamanho da cidade em que se criaram. Em nossos termos: as oportunidades educacionais tendem a se igualar nas camadas superiores da hierarquia social dos centros urbanos dos mais variados tamanhos. 
ela "uma comunidade heterogênea, individualizada e secular", encontrandose entre a população da sede muitas "características do complexo urbano", sendo os seus habitantes portadores de um "ethos urbano"; destaca ainda a diferenciação, mais subjetiva do que objetiva, em termos de traços culturais e sociais, dos habitantes do centro urbano em relação aos das vilas e zonas rurais circundantes ${ }^{186}$.

Os estudos de comunidade feitos no Brasil ${ }^{187}$, no geral de pequenas comunidades situadas nas áreas mais afastadas da influência urbana, nas regiões denominadas por nós de não-urbanizadas ou em enclaves de menos contatos, marginais, no Centro-sul (como por exemplo Cunha, Araçariguama. e as do litoral, em São Paulo ${ }^{188}$ ), mostram algumas vezes a diferenciação cidade-campo equivalente à notada por Harris em Rio das Contas. Entretanto, o tradicionalismo entre elas é quase sempre pronunciado, levando-nos a nos surpreender com os resultados achados por Kahl. No final de contas, pode-se manter, como questão de grau, a nossa afirmativa sobre a maior homogeneização do mundo urbano das regiões urbanizadas do Sul, Centro-sul e faixa litorânea nordestina. São mundos urbanos que se entrelaçam pela porção superior da estrutura social, diferenciando-soe mais e mais das suas zonas rurais, e das populações rurais e urbanas das zonas não-urbanizadas.

O processo de transformação de valores está ainda em curso, mesmo nas grandes metrópoles, e é ligado à assimilação à cultura urbana dos seus contingentes originados no mundo rústico e no geral situados nas camadas inferiores da hierarquia social. Há estudos que salientam as variações de valores relativos à modernização, pelos vários grupos sócio-econômicos ou fazem comparações internacionais, no mesmo sentido. Mencionemos brevemente dois dos mais cuidadosos.

${ }_{187}^{186}$ HARRIS, 1956, págs. 274-289.

${ }^{187}$ Veja-se o rol e a análise de quinze estudos de comunidade realizados no Brasil, publicados de 1948 a 1960, em artigo de GUIDI (1962). Entre alguns outros que foram publicados depois, podem ser citados: Borges COSTA, 1960; Altenfelder SILVA. 1961; ALBERSHEIM, 1962; NOGUEIRA, 1962; A. CANDIDO, 1964

${ }^{188}$ Cf. WILLEMS, 1952; WILLEMS, 1961; e PIERSON, 1951
Silvert e Bonilla ${ }^{189}$, com dados de questionário aplicado, no Rio de Janeiro, a amostras de empresários industriais, operários qualificados e habitantes de favelas (grupos que não só representam pontos diferentes da estrutura social mas também apresentam em sua composição incorporação crescente de elementos de extração rural e semi-rural), analisaram as variações existentes entre tais grupos, quanto à identificação nacional, atitudes para com a educação e valores relativos ao desenvolvimento ${ }^{190}$. Dentre as suas conclusões, destaquemos os trechos mais significativos para os nossos fins.

Se as diferenças entre os empresários industriais, os operários e os favelados podem servir como modelo grosseiro da variabilidade de orientação de valor entre os setores desenvolvidos e tradicionais da sociedade brasileira, pode-se dizer que as diferenças mais dramáticas jazem nos valores relacionados com a organização do trabalho [comprometimento com valores relativos ao trabalho e a formas de organização da moderna empresa industrial], mais no uso que é feito da educação do que na importância que lhe é atribuída, na receptividade ao planejamento e numa inclinação geral para ver alternativas de política nacional em termos de conseqüências econômicas práticas. A disposição a se com prazer com a competição pessoal é outro dos 'indicadores' de 'atitudes preocupadas com o desenvolvimento' (development mindedness), usados neste estudo, que decisivamente diferenciaram os grupos uns dos outros.

Os grupos diferem ainda

\footnotetext{
${ }^{189}$ SILVERT e BONILLA, 1961, págs. 33-59 e 161-191.
}

${ }^{190}$ Os autores distinguem "identificação nacional" de "patriotismo" e "ideologia nacionalista". Sobre o primeiro afirmam tratar-se de "identification with all the fellow-citizens involved in explicitly recognized common activities; and acceptance of the state as the highest institutionalized secular authority (...) the presence or absence of this value may be determined operationally in the testing of attitudes toward social conflict, in the ability of individuals to project themselves into the situation of others at a relatively far remove socially, and in the acceptance of an area susceptible to empirical and rational human decision through the agency of a political mechanism viewed as at least partially neutral and objective”. Ibidem, págs. 13-28 e 315-320 (a citação é das págs. 16-17). 
(...) no grau mais alto de identificação nacional entre os empresários, em contraste com os operários qualificados e favelados, diferença esta estatisticamente significativa ${ }^{191}$

Outro estudo, realizado por Rosen ${ }^{192}$, preocupou-se em analisar, na sua relação com a estrutura familiar e padrões de socialização da criança, o motivo de realização (achievement motivation), característico da sociedade urbano-industrial moderna. A amostra incluiu nesse caso famílias da cidade de São Paulo e de Rio Claro no interior do Estado. Nas suas conclusões o autor compara os resultados com outros obtidos nos EUA:

A tendência das mães brasileiras a treinar seus filhos em autoconfiança (self-reliance), autonomia e realização é menor do que a das americanas. Essa ênfase menor em independência e realização associa-se (...) à família autoritária, dominada pelo pai. A indulgência, a superproteção e o autoritarismo experimentados pelos meninos nesse tipo de família [são] fatores significativos responsáveis por ser o motivo de realização bem mais fraco [do que para os americanos], entre os meninos brasileiros ${ }^{193}$.

A prevalência dessa orientação psicológica estaria, pois, associada à persistência da estrutura e de padrões tradicionais da família no Brasil urbano. As variações encontradas para grupos sócio-econômicos - a maior intensidade nos níveis médios do que nos mais altos ou nos mais baixos do motivo de realização - sugerem estar ele associado à mobilidade vertical ${ }^{194}$.

\footnotetext{
${ }^{191}$ Ibidem, págs. 56-58.

192 ROSEN, 1962. Foram estudados meninos de 9 a 11 anos, 167 em São Paulo e 78 em Rio Claro; ${ }^{2}$ ROSEN, 1962. Foram estudados meninos de 9 a 11 anos, 167 em São Paulo e 78 em Rio Claro;
os dados relevantes foram obtidos entre os meninos e suas famílias, mediante observação, entrevistas, questionários e testes psicológicos.

${ }^{193}$ Idem, p.612. Numa nota à p.615. ROSEN observa: "there appears to be a movement, particularly in the large cities, toward a more democratic family structure. Even in remote areas of Brazil, the writer has encountered men who, reacting against what they themselves described as 'dictatorial' and 'tyrannical' parents, were endeavoring to create a more democratic environment in their families. The transition, however, was a painful one, and they often expressed doubt as to the Wisdom of the change".

${ }^{194}$ Ibidem, p.612. Carolina Martuschelli BORI, que estudou características de indivíduos, na cidade de São Paulo, que haviam ascendido, descido ou permanecido no mesmo nível ocupacional de seus pais, anota que esses últimos em relação aos outros tinham menor intensidade do motivo de
}

Os estudos desta ordem são poucos e seus resultados insuficientes para a compreensão dos processos concretos de mudanças de valores que estão a se desenrolar nas grandes cidades brasileiras. Eles apenas revelam a existência de tais processos e, principalmente, a pouca penetração dos valores modernos em todas as camadas urbanas, mormente nas inferiores, em transição entre o rural e o urbano. Indicam também alguns dos outros fenômenos (a família e a mobilidade social) relevantes para a análise da transformação de valores.

A análise procedida neste capítulo indica, em síntese, estar-se dando a integração nacional, sob o ângulo estudado, com o entrelaçamento das várias partes do mundo urbano brasileiro, pelas camadas médias e superiores da hierarquia social. O processo nas regiões urbanizadas do país inclui desde as grandes metrópoles até os pequenos núcleos urbanos. Nas regiões não-urbanizadas a difusão dos valores e estilo de vida urbanos restringe-se àquelas camadas das cidades maiores; nestas áreas tais efeitos da urbanização são muito mais lentos nas pequenas cidades. Ademais, em todas as regiões, esses efeitos quase não chegam a atingir as camadas inferiores da população rural.

Outros processos de transformação do tradicionalismo estão ocorrendo, entretanto, nas regiões urbanizadas do Brasil, tanto nas zonas rurais como nas urbanas. É o que se faz agora mister tratar no nosso último capítulo.

realização (BORI, 1960, p.259). Este trabalho compreendeu o estudo da inteligência, aspirações, orientação de valores, motivo de realização, na sua vinculação com a mobilidade vertical 


\section{VII - Desagregação da sociedade patrimonialista}

O patrimonialismo sobrevive no Brasil, como estrutura, não só nas regiões mais isoladas, como também em pequenas cidades e nas zonas rurais das áreas urbanizadas do país. Nessas últimas áreas, forças econômicas, sociais e políticas - derivadas do desenvolvimento - estão a miná-lo. É nosso propósito neste capítulo examinar alguns dos mecanismos pelos quais isso se está processando, tomando-se como objeto de estudo cidades industriais do interior e a agroindústria de zonas rurais da Bahia e do Nordeste açucareiro. As relações de trabalho, num e noutro caso, são elemento central da organização tradicional. Examinemos com um pouco mais de vagar a questão.

A relação paternalista patrão-dependente é colocada por muitos autores como um traço básico da sociedade tradicional brasileira. Wagley e Harris ${ }^{1}$ destacam a importância nessa sociedade, no presente e no passado, da relação de dependência para com um patrão ("um dono de terra, um comerciante, um empregador ou chefe político"”2); também E. de $\mathrm{Kadt}^{3}$ encontra essa mesma relação e a sua persistência, sob as mais variadas formas, corno traço relevante na nossa organização social; Galjart, por sua vez, salienta como fundamental o grupo de seguidores (following) dos chefes e dos poderosos no Brasil rural, percebendo o mesmo fenômeno até nas ligas camponesas e sindicatos rurais dos nossos dias ${ }^{4}$.

Uma análise recente de Bertram Hutchinson ${ }^{5}$ é característica e particularmente esclarecedora. Ele sublinha com razão estar a origem daquela relação de dependência associada à família patriarcal extensa, que

\footnotetext{
${ }^{1}$ WAGLEY, 1963, págs. 106 e segs., e 1964, p.40; HARRIS, 1956, págs. 57-59.

${ }^{2}$ WAGLEY, 1964, p.40.

${ }^{3}$ E. de KADT, s/d, passim.

${ }^{4}$ GALJART, 1964, especialmente págs. 11-20.

5 B. HUTCHINSON. 1966. Este autor enumera entre as condições originárias do padrão de dependência, além da família patriarcal da grande propriedade rural, a religião tradicional e o ambiente de insegurança dos dependentes (melhor diria, a nosso ver, a dependência de fato existente). Para nós, aquela religião e esta dependência são elementos da mesma unidade estrutural: a grande família patriarcal da fazenda.
}

inclui, como vimos, aquela periferia constituída de indivíduos e grupos conjugais, agregados, afilhados e dependentes de toda espécie, unidade social que se assentava sobre a grande propriedade. Escreve aquele autor:

De modo que a influência patriarcal e a correlata relação de dependência, em todo o latifúndio, estendia-se a uma população numerosa, estendia-se, na verdade, até às cidades onde grupos domésticos patriarcais (patriarchal households) de setenta pessoas não eram raros. Verdadeira independência, exceto para a aristocracia rural e a classe de comerciantes ricos das cidades, não era um objetivo prático para o grosso da população. A grande maioria da população rural era completamente dependente, econômica, política e socialmente (...) dos grandes proprietários de terra (...). Um homem que não tinha amparo (patronage), que não se juntava ao séqüito de um dono de terra, então como ainda hoje em muitos lugares, não era de se invejar (págs. 11-12).

Aponta o mesmo autor a associação da ubiquiidade das relações de dependência com atitudes de desprezo ao trabalho manual, com o baixo desenvolvimento da iniciativa, seja individual ou grupal, com a ausência ou rudimentarismo de formas de cooperação entre iguais, com a tendência a valer-se de uma rede extensa de parentesco e com as crenças e atitudes do catolicismo rural ${ }^{6}$.

Até os valores tradicionais de ocupação independente ${ }^{7}$ são, apropriadamente, relacionados à incessante procura da figura de um protetor. Sobre este ponto escreve:

Os objetivos associados de dependência e independência não são considerados no Brasil como incompatíveis (...) Sente-se que é mais fácil a perda de independência ocorrer com alguém sem protetor, do que com alguém que possa contar com outros nas emergências. Noutras palavras, uma dependência limitada em certos aspectos da vida é aceita, em parte, porque permite a expressão de independência noutros aspectos... (p.20).

\footnotetext{
${ }^{6}$ Ver, sobre este último ponto o que se pôs acima, págs. 124-125.

${ }^{7}$ É pertinente sobre isto o que se disse acima (págs. 173-174), sobre os operários de origem rural
} 
Finalmente, Hutchinson nota a sobrevivência dessas relações, atitudes e valores, no meio urbano-industrial, na dependência em relação ao político demagogo, no filhotismo e nepotismo prevalecentes na administração pública, nas universidades e nas mais variadas organizações, mormente entre as camadas médias, mesmo nas atitudes relativas à legislação (do trabalho, de previdência social, etc.) e até nas para com o Governo, do qual tudo se espera.

A relação de dependência, analisada por esses autores, e a sua sobrevivência sob novas formas, no Brasil de hoje, mesmo em suas partes mais modernizadas, são fenômenos indubitavelmente de grande relevância ${ }^{8}$. Não devemos esquecer-nos, entretanto, que as conseqüências dessas relações, valores e atitudes, quando fazem parte de uma estrutura de poder como a patrimonialista, são diferentes das que resultam quando tais fenômenos, modificados, se inserem na organização social e política, muito mais complexa, do Brasil urbano-industrial. Para aceitar tal fato basta lembrar, primeiramente, que a sobrevivência de tais relações, transformadas, no meio urbano, na política de massa e nas "panelinhas político-econômicas", é elemento fundamental da nova estrutura de poder do país e, em segundo lugar, que da análise procedida depreende-se que o desenvolvimento, no modo particular pelo qual se deu, e a nova estrutura política, se inter-relacionam intimamente. É importante apontar a continuidade cultural no meio urbano-industrial das relações de dependência, mas isso não nos deve fazer esquecer o fato de que essas relações, como parte da nova sociedade, funcionam de modo diferente.

O nosso tema neste capítulo é a desagregação das estruturas patrimonialistas nas quais se inserem tais relações de dependência (no geral, como relações de trabalho), sob o impacto da sociedade urbano-industrial em formação. (A sobrevivência daquelas relações no Brasil moderno já se acha implícita no tratamento dado aos temas dos nossos capítulos anteriores).

${ }^{8}$ De KADT (s/d), por exemplo, vê, entre os obstáculos mais importantes ao esforço de reforma
social, "[the] deep-seated tendencies in Brazil to look to a patrão (landowner, political boss, priest or social, "[the] deep-seated tendencies in Brazil to look to a pat
the Federal government) for the solution of all problems".
Recoloquemos, porém, mais explicitamente a questão. A vida social no Império e na República Velha pode ser caracterizada como parte de uma ordem patrimonialista ${ }^{9}$. O coronelismo, tal como foi tratado ${ }^{10}$, deve ser visto como o aspecto político, durante a Primeira República, de tal ordem social. Esse sistema político está intimamente ligado à permanência das relações patrimonialistas de trabalho, que vigoram em comunidades rurais e semirurais e mesmo em pequenas cidades industriais do país.

Os influxos da sociedade urbano-industrial e, sobretudo, a nova estrutura política significam forças econômicas, sociais e políticas que, atingindo as comunidades locais tradicionais, solapam, gradual e irreversivelmente, a sua organização patrimonialista. Ilustremos concisamente com as duas situações já aludidas, a das comunidades industriais tradicionalizadas e a da agroindústria no Nordeste.

Nas primeiras, fábricas antiquadas sobreviveram à custa de um mercado regional, para tecidos baratos, relativamente fechado (devido, antes de mais nada, aos altos custos de transporte) e da mão-de-obra barata. As relações industriais nessas comunidades assimilaram-se ao padrão patrimonialista prevalecente nas zonas rurais circundantes (das quais provém a grande maioria dos trabalhadores) e o quadro administrativo e supervisor (mestres e contramestres), que se constituiu, é em alto grau de cunho patrimonialista e não racional-legal (burocrático) ${ }^{11}$.

A análise das condições sob as quais começam a mudar as relações de trabalho nestas comunidades, até a quebra do seu caráter patrimonialista e o estabelecimento de sindicatos independentes, leva-nos a examinar forças e tendências originadas fora das comunidades e que precisam ser interpretadas no contexto da estrutura nacional de poder em mudança.

${ }^{9} \mathrm{O}$ conceito do patrimonialismo parece-nos útil como instrumento de análise. Note-se, porém, a crítica feita por M. W. VIEIRA DA CUNHA da sua aplicação à sociedade tradicional brasileira ("Prefácio", in LOPES, 1964, p.11).

${ }^{10}$ Ver, acima, p.89-91.

${ }^{11}$ Usamos nesta parte o nosso estudo das relações industriais em duas cidades industriais da Zona da Mata, em Minas Gerais (LOPES, 1967). Ver, também, as observações de J. M. CARVALHO (1966) sobre Barbacena. 
Somos forçados a considerar o impacto, no nível da comunidade local, de leis e regulamentos federais, especialmente no campo do trabalho e no eleitoral. Notamos, entretanto, que algumas dessas leis, por exemplo a que permite e regulamenta a formação de sindicatos, existiam bem antes de se tornarem uma realidade social e afetarem as mentes e as ações dos homens nessas partes do Brasil. Tornaram-se realidade, no período mais recente, com a alteração da situação política em cada comunidade, alteração derivada de mudança da estrutura de poder em nível nacional.

Durante a Primeira República a oligarquia estadual manifestava-se na comunidade local como um monopólio de poder por uma única facção política. Não que não existissem lutas políticas. Ao contrário, essa era a situação normal em todo o Brasil: dois "clãs" políticos (famílias extensas) participavam de ferrenha luta e, com os seus seguidores, dividiam verticalmente a sociedade ${ }^{12}$. O fundamental, entretanto, é que em qualquer momento todas as posições de poder na comunidade estavam controladas por uma das facções políticas. A ascensão política da outra facção, quando ocorria, significava uma mudança completa em pouco tempo, e a ocupação pelo novo grupo de todos os focos locais de poder. O grupo dominante num dado momento detinha, localmente, o monopólio de poder e era apoiado pela oligarquia estadual ${ }^{13}$.

O principal resultado da transformação política do Brasil para os municípios do interior foi que as suas estruturas políticas deixaram de ser monolíticas. Hoje em dia, embora em termos gerais um único "clã" ainda domina politicamente as comunidades mais tradicionais, é raro não haver algumas posições de poder preenchidas por pessoas independentes ou mesmo em oposição ao grupo local dominante. Noutras palavras, processou-se, em maior ou menor grau, como consequiência geral da transformação política nacional, um enfraquecimento da estrutura patrimonialista das pequenas comunidades semi-rurais ou urbanas. Os

\footnotetext{
${ }^{12}$ Há muitos estudos da política local em comunidades brasileiras publicados nos últimos anos, vários na Revista Brasileira de Estudos Políticos. Ver, por exemplo, os comentários de Orlando CARVALHO (1957, págs. 102 e segs.) sobre o "bipartidarismo" local em Minas Gerais.

${ }^{13}$ Ver nota 3 do capítulo V (págs. 89-90).
}

grupos representados politicamente nos níveis federal e estaduais tomaramse por demais diferenciados para uma estrutura monolítica sustentar-se localmente. Isso é verdade, mesmo levando-se em conta o reforço muito freqüente (e que já se apontou ${ }^{14}$ ) do poder dos chefes políticos e coronéis das áreas tradicionais pela estrutura político-administrativa da União e do Estado. A diferenciação de interesses políticos faz com que raramente tal apoio se dê sem a ocorrência de oposição de forças: às vezes isso se dá entre os níveis estadual e federal, às vezes entre órgãos do mesmo nível. Tais contradições no apoio às facções locais pelos níveis políticos superiores são ainda mais prováveis quando se trata das áreas urbanizadas do Brasil, onde as camadas inferiores, mesmo nas comunidades do interior, começam a fazer sentir a sua presença, em maior ou menor grau, no cenário político $^{15}$.

Certo número, então, de posições importantes em órgãos locais (dos institutos de previdência e do SAPS, por exemplo), federais e estaduais, são muitas vezes preenchidas por indicação do chefe da oposição municipal. A maioria dos juízes e promotores nas comunidades do interior não depende tanto quanto no passado do grupo dominante no município. Esse enfraquecimento do patrimonialismo local é precondição para tornarem-se efetivas nesse nível as leis trabalhista e eleitoral. A existência na comunidade de pessoas "fora" da estrutura patrimonialista e às quais membros da camada inferior podem recorrer para auxílio e conselhos ${ }^{16}$, é

\footnotetext{
${ }^{14}$ Ver, acima, págs. 115-120.

${ }^{15}$ A análise de BLONDEL (1957, págs. 57-72) sobre os chefes políticos locais no Estado da Paraíba é preciosa. São significativas suas observações de que "o eleitor [das comunidades do interior] vale um pouco mais cada dia. Não é verdadeiramente independente (...) mas já não é de todo dependente. Tem-se interesse por ele. Mesmo os 'chefes políticos' tradicionais procuram a sua popularidade" (p.72). O autor não indagou do papel nessas mudanças das transformações políticas em âmbito nacional. Algumas de suas observações deixam-nos entrever esse papel. O seguinte trecho é especialmente sugestivo: “O ‘chefe político' continua a assegurar a proteção dos seus homens, mas esta proteção com o desenvolvimento da consciência nacional perde mais e mais seu caráter político para tomar aspecto administrativo. O eleitor tomou o hábito de pedir cada vez mais. Ele sabe que existe um Estado e uma Federação que o podem socorrer" (págs. 63 e 65).

${ }^{16}$ Aqui, também, notamos a relação tradicional de dependência, atuando agora, porém, no sentido de enfraquecimento da estrutura patrimonialista.
} 
essencial ao processo pelo qual esses últimos passam a se considerar como tendo "direitos" derivados das leis federais; é também essencial para se compreender porque e como esses indivíduos passam a fazer reivindicações para tornarem efetivos tais direitos. Nas comunidades das áreas urbanizadas do país, tais efeitos somam-se aos do influxo de idéias e valores dos grandes centros, propiciado pelas migrações e pelos meios de comunicação.

Entende-se nessas condições como modificações na lei eleitoral - a introdução do voto secreto e as sucessivas alterações legais para aperfeiçoar o sistema eleitoral - provocaram uma série de novas adaptações do coronelismo, revelando tensões cada vez maiores no sistema, e resultando em seu enfraquecimento progressivo ${ }^{17}$.

Os efeitos das leis trabalhistas fizeram-se sentir de dois modos interrelacionados: 1) pela decretação federal de níveis de salário mínimo, o que significou, durante as últimas décadas, diminuição dos desníveis salariais entre as fábricas, paternalistas e tecnicamente antiquadas, das pequenas cidades industriais do interior e as mais modernas e racionalizadas das grandes metrópoles São Paulo e Rio de Janeiro's ${ }^{18}$ e 2) pela organização de sindicatos independentes.

Os industriais das áreas tradicionais vêem-se numa situação econômica em rápida mudança. Com fábricas muito menos modernas do que as do mesmo gênero nas grandes metrópoles, tanto no sentido tecnológico como no organizacional, perdem, pelo nivelamento progressivo do salário mínimo, a sua principal vantagem, que é o baixo custo da mãode-obra. Por outro lado, durante todo o período os transportes melhoravam e, por conseguinte, alargavam a concorrência. Aqueles industriais reagem de modos não-sistemáticos e freqüentem ente pouco racionais, ao tentarem elevar a produtividade do trabalho e reduzir os custos gerais de mão-de-

${ }^{17}$ Sobre práticas eleitorais no interior de Minas na eleição de 1945, ver O. M. CARVALHO, 1958, págs. 25-55. Ver, também, nossas observações sobre a política em duas comunidades mineiras (LOPES, 1967, págs. 96-101).

${ }^{18}$ LOPES. 1967, págs. 76-80. Os sindicatos operários das grandes metrópoles pressionaram o Governo muitas vezes para diminuir os desníveis de salários entre as várias regiões e sub-regiões. Isso também atendia aos interesses dos industriais do Centro-sul (ver nota 137 do capítulo VI, p.166). obra. Continuam, em boa medida, as práticas patrimonialistas (a de "cuidar" de seus operários, a administração "particularista" de pessoal, etc.), mas misturadas agora com tentativas de intensificação do ritmo de trabalho, preocupação esporádica de substituir por mão-de-obra mais barata (mulheres e menores) a mais cara (homens adultos), de aumentar alugueres das casas da fábrica, etc ${ }^{19}$. Tais reações por parte dos empregadores representam, todavia, quebra das relações tradicionais de trabalho e aumento de tensão entre operários e mestres. Estas são as condições que levam à organização do sindicato e motivam os trabalhadores para a ele se associarem e a ele recorrerem, quando precisam de auxílio e conselho, ao invés de procurarem o patrão ou os mestres, como o faziam tradicionalmente. Até o operário usar o presidente do sindicato como portavoz de suas queixas é, aos olhos do patrão tradicional, um ato de deslealdade e rebeldia. Os laços de obrigação e lealdade se quebram. Um processo acumulativo e circular implanta-se e o comportamento e as relações afastam-se cada vez mais dos padrões patrimonialistas. $\mathrm{O}$ processo é irreversível e a sua resultante é a gradual desagregação dos vínculos patrimonialistas.

Um processo similar está ocorrendo em áreas rurais, mais claramente na zona açucareira do Nordeste. Lá também a intensificação dos contatos e comunicações, o sistema econômico muito mais integrado do que no passado e a nova estrutura nacional do poder, fazem sentir seus efeitos e a transformação de uma sociedade predominantemente patrimonialista está sendo acelerada.

Numa análise recente do Nordeste, Furtado delineia alguns dos principais contornos do processo ${ }^{20}$. Ele nos mostra o efeito da elevação do

\footnotetext{
${ }^{19}$ Ver LOPES, 1967, págs. 74-89 e 1966, p.72.

${ }^{20}$ FURTADO. 1964, págs. 137-173. Esse processo já foi mencionado acima (págs. 41-44), ao tratarmos da expansão da cultura da cana e do aumento das migrações para Recife. Não existe pesquisa sociológica de profundidade sobre as mudanças sociais na zona açucareira do Nordeste. Sugerimos, no texto, na base de artigos gerais de vários autores, quais são, a nosso ver, os principais contornos das transformações que lá ocorrem. Sobre a mudança das relações de trabalho na área do açúcar do Recôncavo Baiano, ver H. HUTCHINSON (1957, capo IX) e COSTA PINTO (1958).
} 
preço do açúcar, na última década, na faixa úmida da Zona da Mata. Antes os trabalhadores rurais daquela zona recebiam pequenos tratos de terra para plantar, para o seu uso, produtos de subsistência; esse era um arranjo tradicional preso à condição de em troca trabalharem alguns dias por semana para o proprietário da terra na cultura da cana (por isso eram chamados condiceiros). Agora os trabalhadores passaram cada vez mais a simples assalariados a fim de que toda a terra pudesse ser utilizada para o cultivo da cana $^{21}$. A pressão para aumento de salário foi grande, pois os trabalhadores tinham agora de pagar preços inflacionados, nas feiras locais, pelos produtos de subsistência que antes produziam para si. Do outro lado, os proprietários da terra resistiram ao aumento salarial, pois o custo de produção, devido ao uso de terras piores, estava em elevação.

Como conseqüência o padrão de vida já baixo dos trabalhadores agrícolas foi forçado ainda mais para baixo, e isso ocorria quando a indústria açucareira estava num período de prosperidade. Ao mesmo tempo, o colocar-se os trabalhadores como assalariados significou a sua redistribuição espacial. Antes espalhavam-se por toda a terra do engenho ou da usina; passaram agora a aglomerar-se em núcleos à beira da estrada. Este fato, como nota Furtado, tomou a comunicação entre eles mais fácil, mais intensa a difusão de idéias, assim como propiciou o aparecimento de liderança camponesa ${ }^{22}$. Estas foram as condições para o rápido surto, na última década, do movimento rural no Nordeste (ligas camponesas e sindicatos rurais). Elas, é claro, não bastam para explicá-la.

É preciso lembrar o papel crucial, desempenhado no processo, por políticos de todos os matizes, de órgãos e autoridades federais e estaduais, vários grupos de esquerda, estudantes e sacerdotes católicos. A simples presença desses elementos na cena política do Nordeste, com novas possibilidades de ação, apoiados por organizações urbanas e por amplos segmentos do eleitorado urbano, ilustram claramente o funcionamento da

\footnotetext{
${ }^{21}$ Ver GREENFIELD e BARROS (1964) sobre as forças que impedem e as que impelem a passagem para um regime de salariado puro. As primeiras dizem respeito à conservação do poder político do dono da terra, e as últimas à crescente vinculação ao mercado capitalista.

${ }^{22}$ Sobre o movimento agrário, ver também CALLADO (1960 e 1964) e HEWITT (1965)
}

nova estrutura política no Brasil. A maior divisão do poder e a possibilidade resultante de manipulação de grupos diversos uns contra os outros, parecenos básico, nesse caso também, para se compreender o papel representado pelos protagonistas políticos no fortalecimento do movimento agrário e na formação gradual de liderança camponesa. Não há dúvida que ocorre aqui a persistência da tradicional relação de dependência relativa a um chefe. Como diz Galjart, "as ligas camponesas e os sindicatos rurais [representam] a transformação do antigo grupo de seguidores [following] de um dono de terra no grupo de seguidores de um político ou de um governo", grupos de seguidores que freqüentemente entram em conflito quando seus lideres são adversários políticos ${ }^{23}$. Entretanto, como já dissemos acima, esse modo de ver o fenômeno tende a esquecer as conseqüências diversas que o padrão tradicional tem no novo contexto sócio-político.

Além das condições econômicas e sociais conducentes ao aparecimento do movimento rural e do papel nele de ativistas políticos "de fora", foi também importante o efeito de leis federais, tais como o Estatuto do Trabalhador Rural, aprovado pelo Congresso, no início de 1963. A própria aprovação dessa lei indica a nova estrutura política nacional. Ter ela chegado a se tornar efetiva, pressupôs já estar abalada a estrutura patrimonialista local ${ }^{24}$, assim como o fenômeno correlato de um movimento social suficientemente vigoroso para gerar pressões pela sua aplicação ${ }^{25}$. O movimento de trabalhadores rurais no Nordeste relaciona-se, na realidade, ao fenômeno de desagregação dos padrões patrimonialistas de trabalho (e a sua substituição a longo prazo por uma relação empregador-empregado mais impessoal e menos difusa), processo esse que tem o mesmo caráter irreversível de causalidade acumulativa e circular que verificamos existir nas cidades industriais tradicionalizadas.

As transformações econômica, social e política do país - a integração do mercado nacional, os efeitos de "modernização" difundidos a partir das

\footnotetext{
${ }^{23}$ GALJART, 1964, p.21.

${ }^{24}$ Corrobora a afirmativa do texto a comparação de HEWITT (1965) das relações de trabalho em Pernambuco com as do Paraíba, em 1965.

${ }^{25}$ FURTADO, 1964, p.149.
} 
grandes cidades, a representação no sistema político de interesses e grupos mais heterogêneos e o papel central, naquele sistema, da política de massa provocam, nas pequenas cidades e zonas rurais das regiões urbanizadas, desagregação da ordem patrimonialista. O processo faz-se em diferentes momentos em ritmos diversos e apresenta, por vezes, retrocessos. Num prazo mais longo, todavia, a inserção da organização patrimonialista na sociedade urbano-industrial em formação torna tal processo irreversível ${ }^{26}$.

\footnotetext{
${ }^{26}$ Sobre os modos sutis pelos quais pode ocorrer a mudança, veja-se novamente as observações de
BLONDEL sobre o Estado do Paraíba (ver, acima, a nota 15).

${ }^{26}$ Sobre os modos sutis pelos quais pode ocorrer a mudança, veja-se novamente as observações de
BLONDEL sobre o Estado do Paraíba (ver, acima, a nota 15).
}

\section{Conclusão}

Resumimos nos fins dos vários capítulos e secções deste livro as conclusões referentes aos temas neles tratados. É: desnecessário repeti-las com o mesmo detalhe. Esbocemos agora, em largos traços, o quadro geral das mudanças da sociedade brasileira, que se depreende do estudo feito, numa série de tópicos, colocados numa ordem algo diferente daquela em que foram tratados no corpo da monografia.

1) O desenvolvimento industrial foi, no início, um subproduto da dinâmica do setor exportador da sociedade e economia brasileiras. Assentou-se no mercado urbano que surgira em função daquele setor. A indústria impulsionou-se, através do mecanismo de substituição de importações, nas várias conjunturas propícias (quando se davam rupturas parciais dos nossos vínculos com o mercado mundial), como decorrência não-intencionada de políticas que atendiam, sobretudo, os interesses daquele setor de exportação. Os industriais desde o começo diferenciavamse pouco, econômica e socialmente, da classe senhorial-mercantil.

2) Os sucessivos surtos de industrialização fazem-se pari passu com a progressiva integração do mercado nacional e, por conseguinte, com a crescente concentração geográfica do desenvolvimento industrial no Centro-sul, região mais dinâmica que já no princípio se avantajara às demais. Através dos efeitos do mercado, amortece-se a industrialização das outras regiões. Por outro lado, devido aos mesmos efeitos, passa a alterar-se profundamente a vida das populações rurais e semi-rurais. Por toda a parte declinam as atividades artesanais. Desenvolve-se uma agricultura comercial na região São Paulo-Rio, voltada para o abastecimento do seu mercado urbano; a agropecuária de outras partes do país, como conseqüência, estagna ou entra mesmo em decadência. Mobilizam-se as populações. Por toda a parte demandam elas as cidades, as regiões agrícolas pioneiras e o Centro-sul, onde são mais abundantes as oportunidades de trabalho rural e urbano.

3) A esses efeitos, juntam-se outros no mesmo sentido, aqueles a que denominamos efeitos de "modernização"; esses últimos se associam à constituição da rede de transportes e comunicações, à extensão do sistema educacional e à difusão da legislação social e serviços públicos. Através de todos esses fenômenos se faz sentir a influência urbana dos grandes centros. 
(Revelam eles igualmente a nova ação político-governamental, transformada e fortalecida.) Tratam-se todos de fatores que também desarraigam as populações rurais e dos pequenos centros, cujo modo de vida já vinha sendo solapado, seja pela penetração do mercado, seja pela decadência da economia rural.

4) O processo de urbanização dá-se em todo o país, pela convergência de tais processos econômicos, sociais e políticos, e apresentase desvinculado, em certa medida, do progresso econômico regional. Crescem as cidades do Centro-sul, do Sul e da área litorânea do Nordeste com diferenças de ritmo bem menores do que as que prevalecem no aumento, numa e noutras, das oportunidades de trabalho urbano. Engrossam-se as populações urbanas sub-ocupadas ou desocupadas nas partes menos desenvolvidas, sem deixarem porém de estar presentes, dada a forma pela qual se dá o processo de industrialização, até mesmo no Centrosul.

5) A transformação política entrosa-se com as econômicas e sociais. Os processos de industrialização, com a diferenciação de interesses que acarreta, e de crescimento das aglomerações urbanas, fazem-se sentir no nível do Estado. O Governo Central e o dos Estados mais desenvolvidos, inserindo-se numa situação de profunda mudança da estrutura de poder e da vida política, respondem mais e mais a interesses variados e dispares e à presença da massa urbana no cenário político. A organização e a ação do Estado desenvolvem-se de modo diverso nas várias regiões. Nas mais adiantadas o aparelho estatal cresce e racionaliza-se. Ele se multiplica em serviços para as populações dos centros urbanos, serviços que começam a se estender às zonas rurais circundantes; ele se transforma, sobretudo, com a emergência de um projeto de industrialização, nascido em movimento social do qual participaram, em papéis distintos, setores médios urbanos, massas populares e representantes do empresariado. Deste projeto resulta a interferência deliberada do Estado na vida econômica e social. Do outro lado, o mesmo Estado, nas regiões atrasadas, num esforço de sustentação do poder e da ordem social, entrosa-se com o coronelismo, que, embora modificado, nelas perdura.

6) Os efeitos dos fatores econômicos e sociais ocorrem no contexto do novo sistema político. Este fato revela-se nas mais diversas mudanças em curso, tanto nas partes modernas do país, quanto nas tradicionais: revela-se na homogeneização do nosso mundo urbano, na situação e comportamento das novas camadas sociais e. na desagregação da ordem patrimonialista nas comunidades das regiões urbanizadas.

Por um lado, não há dúvida, as populações urbanas diferenciam-se, do ponto de vista econômico, devido às desigualdades regionais crescentes com que, sob as políticas industrializadoras, grosso modo, continua a se fazer o desenvolvimento. Do outro, porém, os meios modernos de comunicação, a educação, a estrutura institucional e as condições mesmas de vida urbana - fatores todos, note-se, derivados em parte da nova atuação estatal agem num sentido claramente uniformiza dor. O comportamento, através das transformações que se operam na família e na religião, por exemplo, assim como as atitudes, os valores e as aspirações, sofrem tais influências. Delineia-se no Brasil um mundo urbano, nas suas regiões urbanizadas adiantadas ou atrasadas, mundo que se homogeneíza.

Industriais, novas classes médias, operariado, não chegam a desenvolver consciência e ação próprias adequadas à sua situação social. Deriva tal fato do próprio processo de constituição dessas camadas (sua recentividade, heterogeneidade, etc.), do qual faz parte a sua inserção na nova estrutura política (a persistência de modos tradicionais de obtenção de favores governamentais, a participação por amplos setores da população urbana na sociedade de massa, a "radicalização" inerente a política de manipulação das camadas populares).

Em comunidades tradicionais, nas regiões urbanizadas, os efeitos da intensificação dos contatos e comunicações somam-se aos do mercado e da nova estrutura nacional de poder. Novos valores e idéias, o acirramento da concorrência por parte de empresas das áreas adiantadas, devido à extensão da rede de transportes e ao efeito nivelador da legislação do trabalho, o enfraquecimento político dos grupos dominantes locais, a influência da legislação federal, convergem para provocar a desagregação das relações tradicionais de trabalho e, com elas, de toda a ordem patrimonialista.

Nós nos propusemos a mostrar as inter-relações das mais diversas mudanças econômicas, sociais e políticas, quando vistas sob o ângulo da constituição de um sistema industrial e de uma sociedade urbano-industrial no Brasil. Para tanto, a nossa atenção esteve sempre voltada para as 
características particulares, resultantes dos processos sociais concretos em curso, que tal sistema e sociedade assumem no país. Além disso, como a sociedade urbano-industrial envolve integração crescente do corpo social integração sob os aspectos econômico, psicossocial e político focalizamos, para interpretar a mudança social, a integração crescente do mercado, a intensificação dos contatos e comunicações (com a perda gradativa do localismo das populações interioranas e a difusão do estilo urbano de vida) e a extensão e fortalecimento progressivos do aparelho político-governamental.

Dessas várias perspectivas, foi-nos possível, com o uso dos resultados de muitos estudos particulares, e com dados às vezes precários para os nossos fins, delinear os contornos gerais do processo de transformação da sociedade brasileira.

A análise procedida revelou-se frutífera para a colocação de problemas para indagação e pesquisa futuras. Muitas hipóteses específicas a determinados campos da vida social foram formuladas num e noutro passo do livro. Duas questões maiores, que não podemos' aqui tratar, devem ser ao menos levantadas.

O processo de mudança da sociedade brasileira resulta em efeitos regionais diferencia dores (produzindo a urbanização com características diferentes nas regiões adiantadas e atrasadas, o crescimento também diverso da burocracia do Estado, numa e noutras regiões), assim como outros que são uniformizadores (a homogeneização do mundo urbano). A questão que aqui se coloca é a das consequiências gerais de tais fatos para as regiões atrasadas, onde significam, em suma, crescente descompasso entre os aspectos sociais e econômicos do desenvolvimento. Mais importante ainda, tais fatos, como de resto muitas das outras conclusões a que chegamos, colocam em dúvida a propriedade de caracterizar-se a transformação em curso no Brasil como processo de constituição de uma sociedade urbanoindustrial, à semelhança da existente nos países capitalistas adiantados. Tudo indica que a industrialização dependente dos países periféricos conduz à formação de uma sociedade urbano-industrial na qual modernização e marginalização caminham de mãos dadas. Apesar de já ter sido tratado por vários autores ${ }^{1}$, este tema mereceria ser objeto de maiores esforços teóricos.

Outro problema levantado, de relevância capital, e sem dúvida o maior de todos, é o da continuidade do desenvolvimento. Embora tocado num e noutro ponto, ele ultrapassa os limites que impusemos para esta monografia. Aqui, basta lembrar que agente e situação condicionam-se mutuamente. $\mathrm{O}$ processo de transformação global é, ao mesmo tempo, resultado dos múltiplos agentes sociais e cena em que se desenrola a ação desses agentes. Somente neste amplo contexto pode-se chegar à compreensão do desenvolvimento como processo social e ver-se as alternativas que se abrem à história.
${ }^{1}$ Ver, entre outros, CARDOSO e REYNA, 1967, e QUIJANO, 1967. Nós pretendemos elaborar trabalho futuro nesse sentido. 


\section{Bibliografia}

ALBERSHEIM, U., 1962, Uma comunidade teuto-brasileira: Jarim, Centro Brasileiro de Pesquisas Educacionais, Rio de Janeiro.

ALMEIDA, V. U. de, e T. MENDES SOBRINHO, 1951, Migração ruralurbana, Secretaria da Agricultura, São Paulo.

ANDRADE, C. de S., 1952, "Migrantes nacionais no Estado de São Paulo", Sociologia, vol. XIV, $\mathrm{n}^{\circ}$. 2, págs. 111-130.

ANDRADE, M. C., 1963, Terra e homem no Nordeste, Editora Brasiliense, São Paulo.

ARAÚJO, A. M., 1955, "A família numa comunidade alagoana", Sociologia, vol. XVII, nº. 2, págs. 113-131.

AZEVEDO, T., 1948, Serviço social e problemas baianos, Escola de Serviço Social, Bahia, págs. 15-19.

BAER, W., 1964, "Regional Inequality and Economic Growth in Brazil", Economic Development and Cultural Change, vol. XII, nº. 3, págs. 268-285.

BANCO DO NORDESTE DO BRASIL S. A., 1958, Aspectos econômicos do artesanato nordestino, Escritório Técnico de Estudos Econômicos do Nordeste, Fortaleza.

BASTIDE, R., 1960, Les religions africaines au Brésil, Presses Universitaires de France, Paris. Paris.

s/d, Sociologie du Brésil, Centre de Documentation Universitaire,

BAZZANELLA, W., 1963, "Industrialização e urbanização no Brasil", América Latina, ano VI, no . 1, p.327.

BENDIX, R., 1956, Work and Authority in Industry, John Wiley, Nova York.

BENSMAN, J., e B. ROSENBERG, 1963, "Mass Media and Mass Culture", in P. OLSON (org.), America as a Mass Society; Changing Community and Identity, The Free Press, Glencoe, págs. 166-183.

BLAIR, T. L., 1960, "Social Structure and Information Exposure in Rural Brazil", Rural Sociology, vol. XXV, nº. 1, págs. 65-75.

BLONDEL, J., 19.57, As condições da vida política no Estado da Paraíba, Fundação Getúlio Vargas, Rio de Janeiro.
BLUMER, H., 1959, "The Study of Urbanization and Industrialization; Methodological Deficiencies", Boletim do Centro Latino-Americano de Pesquisas em Ciências Sociais, ano 2, nº. 2, págs. 17-34.

BOGUE, D. J., 1949, The Structure of the Metropolitan Community, University of Michigan Press, Ann Harbor.

BONILLA, F., 1963, “A National Ideology for Development: Brazil”, in K. H. SILVERT (org.), Expectant Peoples: Nationalism and Development, Vintage Books, Nova York, 1967, págs. 232-264.

BORGES, T. P. Accioly, 1955, Migrações internas no Brasil, Comissão Nacional de Política Agrária, Rio de Janeiro.

BORI, C. M., 1960, "O indivíduo e a mobilidade", in B. HUTCHINSON e outros, Mobilidade e trabalho, Centro Brasileiro de Pesquisas Educacionais, Rio de Janeiro, págs. 230-280.

BRADY, R. A., 1943, Business as a System of Power, Columbia University Press, Nova York.

CALlADO, A., 1960, Os industriais da seca e os "Galileus" de Pernambuco, Editora Civilização Brasileira, Rio de Janeiro. 1964, Tempo de Arraes, José Álvaro, Rio de Janeiro.

CALDEIRA, C., 1956, Mutirão, Companhia Editora Nacional, São Paulo.

CAMARGO, C. P. F. de, 1952, "Alguns problemas jurídicos em XiqueXique”, Sociologia, vol. XIV, nº. 4, págs. 293-309. Paulo.

1961, Kardecismo e umbanda, Livraria Pioneira Editora, São

CAMARGO, J. F., 1957, Exxodo rural no Brasil, Boletim no. 1 da Faculdade de Ciências Econômicas e Administrativas, São Paulo, págs. 91-110.

CAMPOS SALES, 1908, Da propaganda à presidência, Tip. A Editora, Lisboa.

CANDIDO, A., 1951, "The Brazilian Family", in T. L. SMITH e A. MARCHANT (orgs.), Brazil, Portrait of Half a Continent, Nova York.

1964, Os parceiros do Rio Bonito, Livraria José Olympio Editora, Rio de Janeiro.

CARDOSO, F. H., 1961, "Le prolétariat brésilien", Sociologie du Travail, vol. III, no. 4 , págs. 50-65.

1964 (a), Empresário industrial e desenvolvimento econômico, Difusão Européia do Livro, São Paulo. 
1964 (b), "Industrialização e sociedade de massa", Sociologia, vol. XXVI, no. 2, págs. 159-169.

1965 (a), El proceso de desarrollo en América Latina, Instituto Latinoamericano de Planificación Económica y Social, Santiago, mimeografado.

1965 (b), Las elites empresariales en Latinoamérica, Instituto Latinoamericano de Planificación Económica y Social, Santiago, mimeografado.

CARDOSO, F. H., e J. L. REYNA, 1967, "Industrialização, estrutura ocupacional e estratificação social na América Latina", Dados, n. 23, págs. 4-31.

CARVALHO, J. M. de, 1966, "Barbacena: a família, a política e uma hipótese”, Revista Brasileira de Estudos Políticos, nº. 20, págs. 125193.

CARVALHO, O. M., 1957, "Os partidos políticos em Minas Gerais", Revista Brasileira de Estudos Políticos, no. 2, págs. 99-115.

1958, Ensaios de sociologia eleitoral, edições da Revista Brasileira de Estudos Políticos, Belo Horizonte.

CASTALDI, C., 1960, "O ajustamento do imigrante à comunidade paulistana”, in B. HUTCHINSON e outros, Mobilidade e trabalho, Centro Brasileiro de Pesquisas Educacionais, Rio de Janeiro, págs. 280-359.

CENSO ESCOLAR DO BRASIL, Resultados preliminares, 1965, vols. I e II, Comissão Central do Censo Escolar, São Paulo.

CHARDON, R. E., 1966, "Changes in the Geographic Distribution of Population in Brazil, 1950-1960", in E. N. BAKLANOFF (org.), New Perspectives of Brazil, Vanderbilt University Press, Nashville, págs. 155-178.

CLARK, C., 1957, The Conditions of Economic Progress, 3. a edição, Macmillan Co., Londres.

COLE, G. D. H., 1954, "Industrialism", in Encyclopaedia of the Social Sciences, vol. VIII, 11. impressão, Macmillan Co., Nova York, págs. 18-26.

COMISSÃO NACIONAL DE POLÍTICA AGRÁRIA, 1955, Aspectos rurais brasileiros, Ministério da Agricultura, Rio de Janeiro.

COSTA, E. B., 1955, "Relações de família em Cerrado e Retiro", Sociologia, vol. XVII, no. 2, págs. 132-146. s/d, Rio Vermelho (Santa Catarina), manuscrito.

1960, Cerrado e Retiro, Comissão do Vale do São Francisco, Rio de Janeiro.

COSTA PINTO, L. A., 1952, Migrações internas no Brasil, Instituto de Economia da Fundação Mauá, Rio de Janeiro, mimeografado.

1956 "Social Stratification in Brazil", in Transactions of the Third World Congress of Sociology, Amsterdam, 1956, vol. III, International Sociological Association, Londres, págs. 54-65.

1958, Recôncavo, Centro Latino-Americano de Pesquisas Sociais, Rio de Janeiro.

DAVIS, K., 1955, "The Origin and Growth of Urbanization in the World", The American Journal of Sociology, vol. LX, págs. 429-437.

e A. CASIS, 1957, "Urbanization in Latin America", in P. K. HATT e A. J. HEISS JR. (orgs.), Cities and Society, The Free Press, Glencoe, págs. 141-156.

DEMAS, W. G., 1965, The Economics of Development in Small Countries, With Special Reference to the Caribbean, McGill, Montreal.

DI TELLA, T. S., 1964, Una teoria sobre el primer impacto de la industrialización, Instituto Torcuato Di Tella, Buenos Aires.

DUNCAN, O. D., e A. J. REISS JR., 1956, Social Characteristics of Urban and Rural Communities, 1950, John Wiley, Nova York.

FERNANDES, F., 1960, Mudanças sociais no Brasil, Difusão Européia do Livro, São Paulo.

1963, A sociologia numa era de revolução social, Companhia Editora Nacional, São Paulo.

1965, The Dynamics of Socio-Cultural Change in Brazil, manuscrito.

FREYRE, G., 1954, Casa-grande \& senzala, 8. ${ }^{\text {a }}$ edição, Livraria José Olympio Editora, Rio de Janeiro.

FRIEDMANN, G., 1946, Problèmes humains du machinisme industriel, edição revista e aumentada, Librairie Gallimard, Paris.

1950, Où va le travail humain?, edição revista e aumentada, Gallimard, Paris.

FURTADO, C., 1959, Formação econômica do Brasil, Editora Fundo de Cultura, Rio de Janeiro.

1964, Dialética do desenvolvimento, 2. ${ }^{\mathrm{a}}$ edição, Editora Fundo de Cultura, Rio de Janeiro. 
1965, “Obstáculos políticos ao crescimento econômico no Brasil”, Revista Civilização Brasileira, ano I, págs. 129-145.

GALJART, B., 1964, "Class and 'Following' in Rural Brazil”, América Latina, ano 7, n'. 3, págs. 3-24.

GAY, E. F., 1954, "Putting-out System", in Encyclopaedia of Social Sciences, vol. XIII, 11. impressão, The Macmillan Co., Nova York.

GEIGER, P. P., 1963, Evolução da rede urbana brasileira, Centro Brasileiro de Pesquisas Educacionais, Rio de Janeiro.

GONÇALVES, A. C., 1961, As migrações para o Recife - II. Aspectos do crescimento urbano, Instituto Joaquim Nabuco de Pesquisas Sociais, Recife.

GOUVEIA, A. J., 1965, "Desenvolvimento econômico e prestígio de certas ocupações", América Latina, ano 8, nº 4, págs. 66-79.

GREENFIELD, S. M., e E. de V. BARROS, 1964, Industrialized Labor and Traditional Forms in Southeastern Minas Gerais, trabalho apresentado ao Congresso da American Anthropological Association, mimeografado.

GRUPO DE TRABALHO PARA O DESENVOLVIMENTO DO NORDESTE, 1959, Uma política de desenvolvimento para o Nordeste, Departamento de Imprensa, Rio de Janeiro.

GUIDI, M. L. M., 1962, "Elementos de análise dos 'estudos de comunidade' realizados no Brasil e publicados de 1948 a 1960”, Educação e ciências sociais, ano 7, vol. X, nº . 19, págs. 45-87.

GUIMARÃES, F. de M. S., "Divisão regional do Brasil", Boletim geográfico, ano 6, nº .68 , págs. 964-965.

HARRIS, M., 1956. Town and Country in Brazil, Columbia University Press, Nova York.

HENDERSON, J. J., 1957, "Urbanization and the World Community", The Annals of the American Academy of Political and Social Science, vol. CCCXIV, págs. 147-155.

HEWITT, C. N., 1965, An Introduction to the Rural Labor Movement of Pernambuco, Columbia University, Nova York, mimeografado.

HIRSHMAN, A. O., 1963, Journeys Toward Progress, The Twentieth Century Fund, Nova York.

HOSELITZ, B. F., 1955, "The City, the Factory, and Economic Growth", The American Economic Review, vol. XLV, no 2.

HUTCHINSON, B., 1958, Social Mobility and Education, manuscrito.
1963, "The Migrant Population of Urban Brazil", América Latina, ano 8, no. 2, págs. 41-71.

e outros. 1960, Mobilidade e trabalho, Centro Brasileiro de Pesquisas Educacionais, Rio de Janeiro.

1965, "Colour, Social Status and Fertility in Brazil", América Latina, ano 8, n. 4 , págs. 2-25.

1966, "The Patron - Dependant Relationship in Brazil", Sociologia Ruralis, vol. VI, nº 1, págs. 3-30.

HUTCHINSON, H., 1957, Village and Plantation Life in Northeastern Brazil, University of Washington Press, Seattle.

IANNI, O., 1961, "Estudo de comunidade e conhecimento científico", Revista de Antropologia, vol. IX, n. ${ }^{\text {ss }} 1$ e 2, págs. 109-119.

1963, Industrialização e desenvolvimento social no Brasil, Editora Civilização Brasileiro, Rio de Janeiro.

1965, Estado e capitalismo, Editora Civilização Brasileira, Rio de Janeiro.

IUTAKA, S., "A estratificação social e o uso diferencial de métodos anticoncepcionais no Brasil urbano", América Latina, ano 8, n. 1, págs. 101-119.

JAGUARIBE, H., 1962, Desenvolvimento econômico e desenvolvimento político, Editora Fundo de Cultura, Rio de Janeiro.

JOBIM, J., 1943, Brazil in the Making, The Macmillan Co., Nova York.

KADT, E. de, s/d, Religion, the Church and Social Change in Brazil, manuscrito.

KAHL, J. A., 1965, A Study of Career Values in Brazil and Mexico, Washington University, Saint Louis, mimeografado.

KERR, C., J. T. DUNLOP, F. HARBISON e C. A. MYERS, 1960, Industrialism and Industrial Man, Harvard University Press, Cambridge, Mass.

KORNHAUSER, W., 1959, The Politics of Mass Society, The Free Press, Glencoe.

LABORATÓRIO DE ESTATÍSTICA, 1951, “O aumento da população do Brasil entre 1872 e 1940”, em Pesquisas sobre o desenvolvimento da população do Brasil, IBGE, Rio de Janeiro, págs. 50-62.

LAMBERT, J., 1959, Os dois Brasis, Centro Brasileiro de Pesquisas Educacionais, Rio de Janeiro. 
LEEDS, A., 1964, "Brazilian Careers and Social Structure", American Anthropologist, vol. LXVI, nº 6, parte I, págs. 1.321-1.347.

LOPES, J. R. B., 1959, "Estrutura social e educação no Brasil”, Educação e ciências sociais, ano 4 , vol. IV, $\mathrm{n}^{\circ}$. 10, págs. 53-77.

1960, "Origem social e escolha ocupacional de ginasianos", in B. HUTCHINSON e outros, Mobilidade e trabalho, Centro Brasileiro de Pesquisas Educacionais, Rio de Janeiro, págs. 360-440.

1964, Sociedade industrial no Brasil, Difusão Européia do Livro, São Paulo.

1966, "Some Basic Developments in Brazilian Politics and Society", in E. N. BAKLANOFF (org.), New Perspectives of Brazil, Vanderbilt University Press, Nashville, págs. 59-77. Paulo.

1967, Crise do Brasil arcaico, Difusão Européia do Livro, São

s/d, "O processo histórico e Max Weber", in Sociologia e história, Instituto de Sociologia e Política, São Paulo, págs. 71-91.

MEDEIROS, L. de, 1951, Vilas de malocas, Porto Alegre.

1964, "As cidades no Rio Grande do Sul", in A. PRADO e outros (orgs.), Rio Grande do Sul, Editora Globo, Rio de Janeiro, págs. 69-87.

MELO, M. L. de, 1961, As migrações para o Recife - I. Estudo geográfico, Instituto Joaquim Nabuco de Pesquisas Sociais, Recife.

MILLS, C. W., 1953, White-Collar, Oxford University Press, Nova York.

MIRÓ, C., 1964, "The Population of Latin America”, Demography, vol. I, $\mathrm{n}^{\circ}$. 1, págs. $15-41$.

MONBEIG, P., 1952, Pionniers et planteurs de São Paulo, Armand Colin, Paris.

MONTENEGRO, A. F., 1960, “Tentativa de interpretação das eleições de 1958 no Ceará”, Revista Brasileira de Estudos Políticos, nº 8, págs. 39-49.

MOREIRA, R., 1960, Educação e desenvolvimento no Brasil, Centro Latino-Americano de Pesquisas Sociais, Rio de Janeiro.

MORTARA, C., 1950, "Observações sobre a discriminação da população urbana no Censo de 1940”, Revista Brasileira dos Municípios, ano 3, $\mathrm{n}^{\circ} .9$, págs. 20-55.
1956, “As atividades da população da Bahia, segundo os censos demográficos de 1940 e 1950”, in Análises críticas de resultados dos censos demográficos, IBGE, Rio de Janeiro, págs. 108-113.

1963, "The Development and Structure of Brazil's Population", in J. SPENGLER e O. D. DUNCAN (orgs.), Demographic Analysis, The Free Press, Glencoe, págs. 652-670.

MUTCHLER, D. E., 1965, "Roman Catholicism in Brazil", Studies in Comparative International Development, vol. I, $\mathrm{n}^{\circ} .8$, St. Louis.

NICHOLLS, W. H., 1962, Industrial-Urban Development and Agriculture in São Paulo, Brazil, 1940-1950, Term., Nashville, edição mimeografada da Vanderbilt University.

NOGUEIRA, O., 1962, Família e comunidade, Centro Brasileiro de Pesquisas Educacionais, Rio de Janeiro.

1964, Desenvolvimento de São Paulo, Comissão Interestadual da Bacia Paraná-Uruguai, São Paulo.

s/d., O Município de Leopoldina, manuscrito.

NUNES LEAL, V., 1948, Coronelismo, enxada e voto, Rio de Janeiro.

OBERG, K., 1957, Toledo, Rio de Janeiro.

OLIVEIRA, F. de, 1960, Rio Grande do Sul: um novo Nordeste, Editora Civilização Brasileira, Rio de Janeiro.

OLIVEIRA TÔRRES, J. C., 1961, A formação do federalismo no Brasil, Companhia Editora Nacional, São Paulo.

OLSON, P. (org.), 1963, America as a Mass Society, The Free Press, Glencoe.

PAIM, G., 1957, Industrialização e economia natural, Instituto Superior de Estudos Brasileiros, Rio de Janeiro.

PARA UMA POLÍTICA NACIONAL DE DESENVOLVIMENTO, 1956, Cadernos do nosso tempo, $\mathrm{n}^{\circ}$. 5, págs. 47-188.

PASDERMADJAN, H., 1959, La deuxième révolution industrielle, Presses Universitaires de France, Paris.

PEREIRA, L., 1960 (a), A escola numa área metropolitana, Boletim $\mathrm{n}^{\circ}$. 253 da Faculdade de Filosofia, Ciências e Letras, São Paulo.

1960 (b) "Rendimento e deficiências do ensino primário brasileiro", Revista (da FFCL de Araraquara), ano 1, nº. 1, págs. 5762.

1965, Trabalho e desenvolvimento no Brasil, Difusão Européia do Livro, São Paulo. 
PEREIRA, L. C. B., 1964, “Origens étnicas e sociais do empresário paulista", Revista de Administração de Empresas, n’. 11, págs. 83106.

Pesquisa sobre orçamentos familiares, cidade de São Paulo, 1961-1962, s/d (a), Instituto Brasileiro de Economia, Rio de Janeiro.

Pesquisa sobre orçamentos familiares, interior do Estado de São Paulo, população urbana, 1962-1963, s/d (b), Instituto Brasileiro de Economia, Rio de Janeiro.

Pesquisas sobre as populações urbanas e rurais do Brasil, 1954, Estatística Demográfica $n^{\circ}$. 17, IBGE, Rio de Janeiro.

PIERSON, D., 1951, Cruz das Almas, Smithsonian Institution, Washington), D.C.

Plano trienal de desenvolvimento econômico e social, 1963-1965 (síntese), 1962, Presidência da República.

PRADO JR., C., 1956, História econômica do Brasil, Editora Brasiliense, São Paulo.

1960, "Contribuição para a análise da questão agrária no Brasil”, Revista Brasiliense, n. ${ }^{\circ} 28$, págs. 163-238.

QUEIROZ, M. I. P. de, 1965, O messianismo no Brasil e no mundo, Dominus Editora e Editora da Universidade de São Paulo, São Paulo.

QUIJANO, A., 1967, Dependencia, cambio social y urbanizacion an Latino-america, CEPAL, Division de Asuntos Sociales, Santiago.

RANGEL, I. M., 1956, "Desenvolvimento e projeto", Revista da Faculdade de Ciências Econômicas (da Universidade de Minas Gerais), ano 5, no. 9, págs. $65-173$.

REDFIELD, R., 1949, Civilização e cultura de folk, Livraria Martins Editora, São Paulo.

RIBEIRO, D., 1958, "O programa de pesquisas em cidades-laboratório", Educação e ciências sociais, $\mathrm{n}^{\circ}$. 9, págs. 13-30.

RIBEIRO, R., 1961, "Urbanização e familismo no Nordeste do Brasil", Boletim do Instituto Joaquim Nabuco de Pesquisas Sociais, $\mathrm{n}^{\mathrm{o}}$. 10, págs. 63-79.

RIESSMAN, D. 1950, The Lonely Crowd, Yale University Press, New Haven.

RODRIGUES, L. M., 1966, Conflito industrial e sindicalismo no Brasil, Difusão Européia do Livro, São Paulo.
ROSEN, B. C., 1962, "Socialization and Achievement Motivation in Brazil”, American Sociological Review, vol. XVII, nº. 5, págs. 612624.

SAGMACS, 1960, Aspectos humanos da favela carioca, suplemento especial de O Estado de São Paulo, 13 e 15 de abril de 1960.

SAMPAIO, F. P., 1964, "A profissionalização do administrador paulista", Revista de Administração de Empresas, vol. IV, nº 12, págs. 93-110.

SANTOS, M., 1963, "As migrações para Salvador através da análise do fichário eleitoral”, Revista Brasileira de Estudos Políticos, no. 15, págs. 126-150.

SEERS, D., 1963, "The Stages of Economic Development of a Primary Producer in the Middle of the Twentieth Century", The Economic Bulletin of Ghana, vol. VII, nº. 4, págs. 57-69.

SERVIÇO DE PESQUISAS DO MERCADO DE TRABALHO DE SÃO PAULO, 1954, "Força de trabalho do distrito de São Paulo", Mercado de trabalho, ano 1, nº. 1, págs. 4-14.

SILVA, F. A., 1961, Xique-Xique e Marrecas, Comissão do Vale do São Francisco, Rio de Janeiro.

SILVA, H., 1964, 1922: sangue na areia de Copacabana, Editora Civilização Brasileira, Rio de Janeiro.

1965, 1926: a grande marcha, Editora Civilização Brasileira, Rio de Janeiro.

SILVERT, K. H., e F. BONILLA, 1961, Education and the Social Meaning of Development, American Universities Field Staff, Nova York, mimeografado.

SIMÃO, A., 1961, "Industrialisation et syndicalisme au Brésil", Sociologie du Travail, vol. III, nº. 4, págs. 66-76.

SIMONSEN, R., 1939, Brazil's Industrial Evolution, Escola Livre de Sociologia e Política, São Paulo.

SINDICATO DA INDÚSTRIA DE FIAÇÃO E TECELAGEM EM GERAL, 1942, O reajustamento dos salários mínimos do Brasil, mimeografado.

SINGER, P. I., 1963 (a), Pesquisa sobre mão-de-obra no Brasil, mimeografado.

1963 (b), "A agricultura na bacia Paraná-Uruguai”, Revista Brasileira de Ciências Sociais, vol. III, no. 2, págs. 31-164. 
1965, “A política das camadas dominantes", in O. IANNI e outros, Política e revolução social no Brasil, Editora Civilização Brasileira, Rio de Janeiro, págs. 63-125

1968, Desenvolvimento econômico e evolução urbana, Companhia Editora Nacional, São Paulo.

SMITH, T. L., 1963, Brazil, Louisiana State University Press, Baton Rouge.

SOARES, G. A. D., 1964 (a), "The Political Sociology of Uneven Development in Brazil", in I. L. HOROWITZ (org.), Revolution in Brazil, E. P. Dutton, Nova York.

1964, (b), Economic Development and Political Radicalism, Washington University, Saint Louis, mimeografado.

1965, "As bases ideológicas do lacerdismo", Revista Civilização Brasileira, ano 1, nº. 4, págs. 49-70.

SOVANI, N. V., 1966, Urbanization and Urban India, Asia Publishing House, Londres.

STEIN, Stanley J., 1957 (a), Vassouras, Harvard University Press, Cambridge.

1957 (b), The Brazilian Cotton Manufacture, Harvard University Press, Cambridge.

STRASSMANN, W. P., 1964, "The Industrialist", in J. J. JOHNSON (org.), Continuity and Change in Latin America, Stanford University Press, Stanford, págs. 161-185.

TIETZE, C., 1958, "Human Fertility in Latin America", The Annals of the American Academy of Political and Social Science, vol. CCCXVI, págs. 84-93.

TOURAINE, A., 1955, L'evolution du travail ouvrier aux usines Renault, Centre National de la Recherche Scientifique, Paris.

1961, "Industrialisation et conscience ouvriere à São Paulo", Sociologie du Travail, vol. III, $\mathrm{n}^{\circ}$. 4, págs. 77-95.

VIANNA, Oliveira, 1949, Instituições políticas brasileiras, 2 vols., Livraria José Olympio Editora, Rio de Janeiro.

VIEIRA DA CUNHA, M. W., 1960, "Resistência da burocracia às mudanças sociais, no setor público e no setor privado", in Resistências à mudança, Centro Latino-Americano de Pesquisas em Ciências Sociais, Rio de Janeiro, págs. 195-206.
1963, O sistema administrativo brasileiro, 1930-1950, Centro Brasileiro de Pesquisas Educacionais, Rio de Janeiro.

WAGLEY, C., 1963, An Introduction to Brazil, Columbia University Press, Nova York.

1964, "The Peasant", in J. J. JOHNSON (org.), Continuity and Change in Latin America, Stanford University Press, Stanford, págs. 21-48.

WEBER, M., 1944, Economía y sociedad, 4 vols., Fondo de Cultura Económica, México.

WEFFORT, F., 1965 (a), "Raízes sociais do populismo em São Paulo", Revista Civilização Brasileira, ano 1, nº 2, págs. 39-60.

1965 (b), "Política de massas", in O. IANNI e outros, Política e revolução social no Brasil, Editora Civilização Brasileira, Rio de Janeiro, págs. 159-198.

WHYTE, W. F., 1943, Street Corner Society, The University of Chicago Press, Chicago.

WILLEMS, E., 1945, "Burocracia e patrimonialismo", Administração pública, ano $3, n^{\circ} .3$, págs. 12-17.

1952 (com a colaboração de Gioconda MUSSOLINI), Buzios Island, J. J. Augustin Publisher, Nova York.

1953, "The Structure of the Brazilian Family", Social Forces, vol. XXXI, nº 4, págs. 339-345.

1955 (a), "A família portuguesa contemporânea", Sociologia, vol. XVII, $n^{\circ} .1$, págs. 3-55.

1955 (b), "Protestantism as a Factor of Culture Change in Brazil", Economic Development and Cultural Change, vol. III, nº. 4, págs. 321-333. Paulo.

1961, Uma vila brasileira, Difusão Européia do Livro, São

1966, "Religious Mass Movements and Social Change in Brazil", in E. N. BAKLANOFF (org.), New Perspectives of Brazil, Vanderbilt University Press, Nashville, págs. 205-232. 